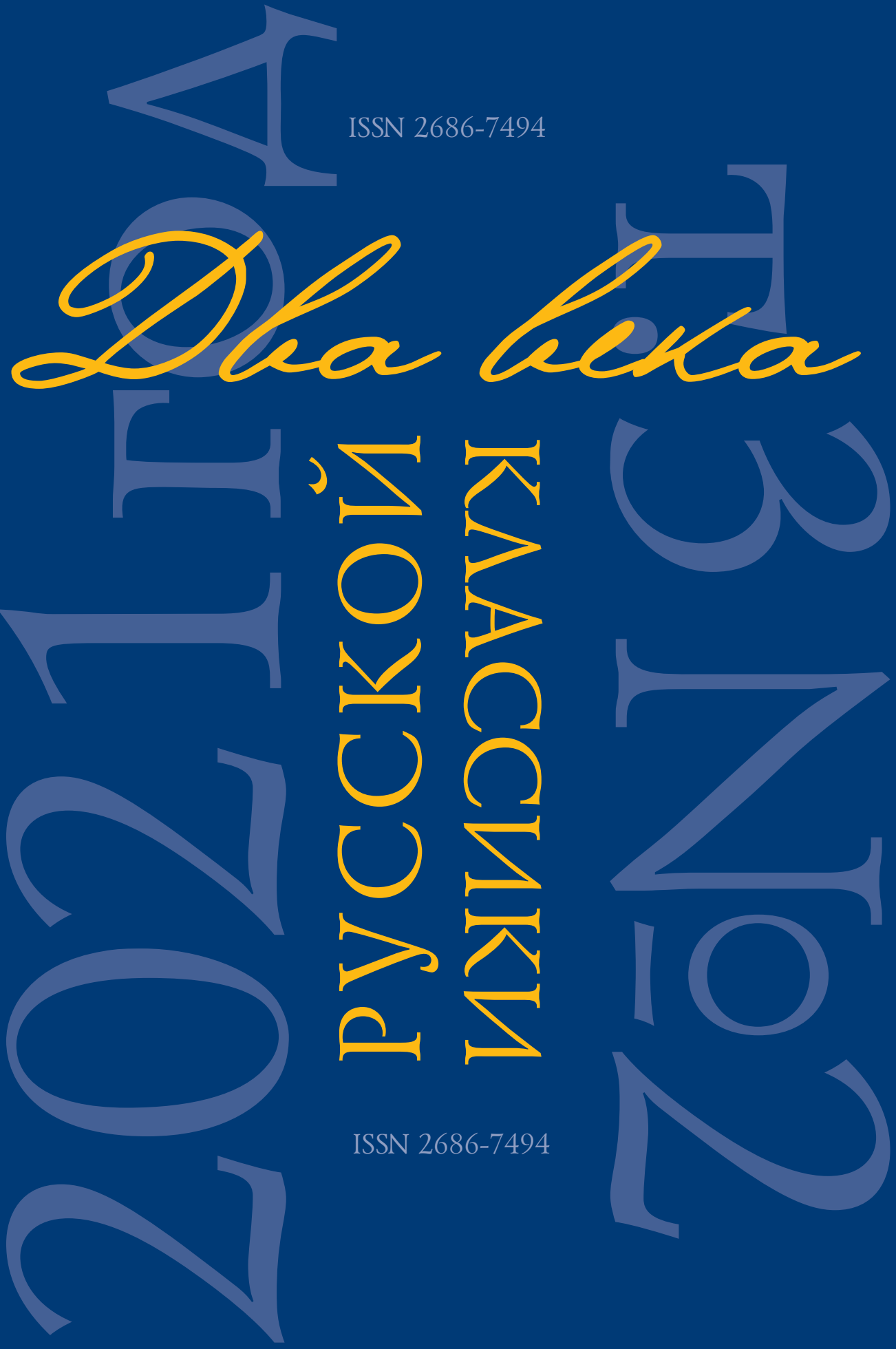


ISSN 2686-7494

\section{Два века Two centuries \\ русской классики of the Russian classics}

[Dva veka russkoi klassiki]

Научный журнал Academic Journal

Выходит с 2019 года Is published since 2019

2021 Том 3 № 2 2021 Volume 3 No. 2

Учредитель и издатель: Founder and publisher:

мировой литературы Institute

им. А.М. Горького of World Literature

Российской of the Russian

академии наук Academy of Science

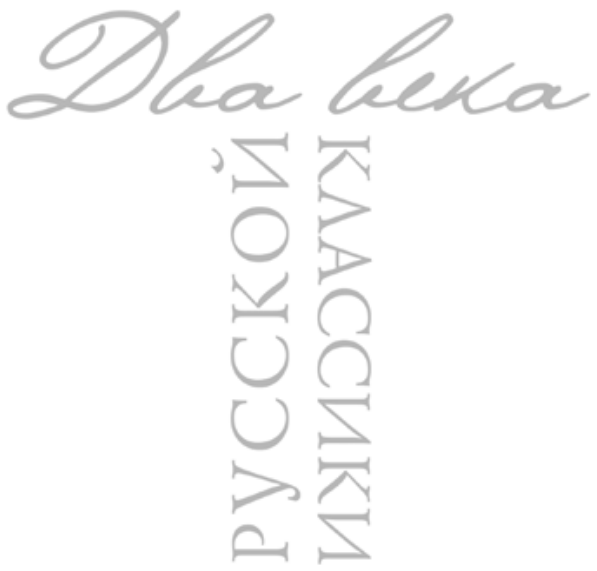




\section{Редакционная коллегия журнала «Два века русской классики»}

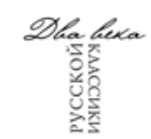

\section{Главный редактор}

Щербакова Марина Ивановна (Институт мировой литературы им. А. М. Горького

Российской академии наук, г. Москва, Россия)

Заместитель главного редактора

Виноградов Игорь Алексеевич (Институт мировой литературы им. А. М. Горького

Российской академии наук, г. Москва, Россия)

Ответственный секретарь

Андреева Валерия Геннадьевна (Институт мировой литературы им. А. М. Горького

Российской академии наук, г. Москва, Россия)

\section{Редакционная коллегия}

Гулин Александр Вадимович (Институт мировой литературы им. А. М. Горького

Российской академии наук, г. Москва, Россия), Гуминский Виктор Мирославович

(Институт мировой литературы им. А. М. Горького Российской академии наук,

г. Москва, Россия), Ивинский Александр Дмитриевич (Институт мировой литературы им. А. М. Горького Российской академии наук, г. Москва, Россия), Троицкий Всеволод Юрьевич Институт мировой литературы им. А. М. Горького Российской академии наук, г. Москва, Россия), Воропаев Владимир Алексеевич (Московский государственный университет им. М. В. Ломоносова, г. Москва, Россия), Генералова Наталья Петровна (Институт русской литературы (Пушкинский Дом) Российской академии наук, г. СанктПетербург, Россия), Захаров Владимир Николаевич (Петрозаводский государственный университет, г. Петрозаводск, Российский фонд фундаментальных исследований, г. Москва, Россия), Коровин Владимир Леонидович (Московский государственный университет им. М. В. Ломоносова, г. Москва, Россия), Лебедев Юрий Владимирович (Костромской государственный университет, г. Кострома, Россия), Михайлова Наталья Ивановна (Государственный музей А. С. Пушкина, г. Москва, Россия), Мосалева Галина Владимировна (Удмуртский государственный университет, г. Ижевск, Россия), Николаева Евгения Васильевна (Московский педагогический государственный университет, г. Москва, Россия), Николаева Светлана Юрьевна (Тверской государственный университет, г. Тверь, Россия), Федоров Алексей Владимирович (издательство «Русское слово», г. Москва, Россия), Чернышева Елена Геннадьевна (Московский педагогический государственный университет, г. Москва, Россия)

\section{Международный редакционный совет}

Авидзба Василий Шамониевич (научно-исследовательский центр «Абхазская энциклопедия», г. Сухум, Абхазия), Гини Джузеппе (Университет им. Карло Бо, г. Урбино,

Италия), Донсков Андрей Александрович (Славянская исследовательская группа при университете Оттавы, г. Оттава, Канада), Кавацца Антонелла (Университет им. Карло Бо, г. Урбино, Италия), Луцевич Людмила Федоровна (Варшавский университет, г. Варшава, Польша), Михед Павел Владимирович (Институт литературы им. Т. Шевченко Национальной академии наук Украины, г. Киев, Украина), Олджай Тюркан (Стамбульский университет, г. Стамбул, Турция), Пиотровска Иоанна (Варшавский университет, г. Варшава, Польша), Саверченко Иван Васильевич («Институт литературоведения им. Янки Купалы»

Национальной академии наук Беларуси, г. Минск, Беларусь), Рафаэль Гусман Тирадо

$$
\text { (г. Гранада, Испания) }
$$




\section{The editorial board of the journal "Two centuries of the Russian classics"}

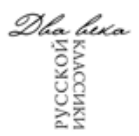

\section{Editor-in-Chief}

Marina I. Shcherbakova (A. M. Gorky Institute of World Literature of the Russian Academy of Sciences, Moscow, Russia)

Deputy Editor-in-Chief

Igor' A. Vinogradov (A. M. Gorky Institute of World Literature of the Russian Academy of Sciences, Moscow, Russia)

Managing Editor

Valeria G. Andreeva (A. M. Gorky Institute of World Literature of the Russian Academy of Sciences, Moscow, Russia)

Editorial Board

Alexander V. Gulin (A. M. Gorky Institute

of World Literature of the Russian Academy of Sciences, Moscow, Russia), Victor M. Guminsky (A. M. Gorky Institute of World Literature of the Russian Academy of Sciences, Moscow, Russia), Alexander D. Ivinsky (A. M. Gorky Institute of World Literature of the Russian Academy of Sciences, Moscow, Russia),

Vsevolod Yu. Troitsky (A. M. Gorky Institute of World Literature of the Russian Academy of Sciences, Moscow, Russia),

Vladimir A. Voropayev (Lomonosov Moscow State University, Moscow, Russia),

Natalya P. Generalova (Institute of Russian Literature (The Pushkin House) of the Russian Academy of Sciences, St. Petersburg, Russia),

Vladimir N. Zakharov (Petrozavodsk State University, Petrozavodsk, Russian Foundation for Basic Research, Moscow, Russia),

Vladimir L. Korovin (Lomonosov Moscow State University, Moscow, Russia), Yuriy V. Lebedev (Kostroma State University, Kostroma, Russia),

Natalya I. Mikhaylova (State Museum of A. S. Pushkin, Moscow, Russia), Galina V. Mosaleva (Udmurt State University, Izhevsk, Russia),

Evgenia V. Nikolaeva (Moscow Pedagogical State University, Moscow, Russia), Svetlana Yu. Nikolaeva (Tver State University, Tver, Russia),

Alexey V. Fedorov (Russian Word publishing house, Moscow, Russia),

Elena G. Chernysheva (Moscow Pedagogical State University, Moscow, Russia)

\section{International Editorial Council}

Vasily Sh. Avidzba (Abkhazian Encyclopedia Research center, Sukhum, Abkhazia), Giuseppe Genya (University of Carlo Bo, Urbino, Italy),

Andrey A. Donskov (Slavic Research Group at the University of Ottawa, Ottawa, Canada), Antonella Kavazza (University of Carlo Bo, Urbino, Italy), Lyudmila F Lutsevich (Warsaw University, Warsaw, Poland),

Pavel V. Mikhed (Institute of literature of T. Shevchenko of National Academy of Sciences of Ukraine, Kiev, Ukraine), Oldzhay Tyurkan (Istanbul University, Istanbul, Turkey), Ioann Piotrovsk (Warsaw University, Warsaw, Poland),

Ivan V. Saverchenko (Institute of Literary Criticism of Janka Kupala of National Academy of Sciences of Belarus, Minsk, Belarus), Raphael G. Tirado (Granada, Spain) 


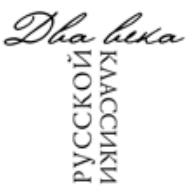

\section{Содержание}

\section{Русская литература XVIII-XIX столетий}

6 Серягин С. Н. Неизвестный рисунок Н. В. Гоголя

16 Жданов С. C. Principal Features of the Imaginal-geographic Germany in Russian Travelogues of the Late $18^{\text {th }}-$ First Half of the $19^{\text {th }}$ Centuries

40 Святославский А. В. Образы природы в русской одической поэзии XVIII - начала XIX вв.: функциональные особенности и значение для дальнейшего литературного процесса

62 Шакирова Л. Г. Символика времени и вечности в лирике природы Ф. И. Тютчева

96 Гулин А. В. Декабристы в эпическом отображении Л. Н. Толстого и Н. А. Некрасова

120 Пырков И. В. Образ газеты и значение периодической прессы как одной из основ информационного мира в романе И. А. Гончарова «Обломов»

138 Фёдорова Е. А. Роман-эксперимент Н. А. Некрасова и Ф. М. Достоевского в свете этнопоэтики

150 Фетисенко О. Л. «Аскетическая философия» К. Н. Леонтьева: тезаурус и контекст

Текстология

168 Ивинский А. Д. О стихотворении М. Н. Муравьева «Живописец» (по материалам ОР РГБ и РО ИРЛИ)

186 Можарова М. А. «Основной бас»: к истории одного музыкального образа в романе Л. Н. Толстого «Анна Каренина»

202 Макарова В. А. Self-praise and Positive Self-assessment in Chekhov's Plays

Научная жизнь

230 Щербаков В. И. О подготовке в ИМЛИ РАН «Сочинений» Николая Соловьева 


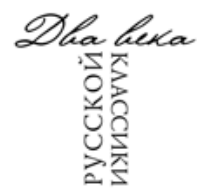

\section{Contents}

Russian Literature of the $18^{\text {th }}-19^{\text {th }}$ Centuries

6 Sergey N. Seryagin. Unknown Drawing by Nikolay Gogol

16 Sergey S. Zhdanov. Principal Features of the Imaginal-geographic Germany in Russian Travelogues of the Late $18^{\text {th }}-$ First Half of the $19^{\text {th }}$ Centuries

40 Alexey V. Svyatoslavsky. Nature Images in Russian Odic Poetry of the $18^{\text {th }}-$ Early $19^{\text {th }}$ Centuries: Functional Role and Influence on the Further Literary Process

62 Ludmila G. Shakirova. Symbols of Time and Eternity in F. I. Tyutchev's Nature Lyrics

96 Aleksandr V. Gulin. The Decembrists in the Epic Representation of L. N. Tolstoy and N. A. Nekrasov

120 Ivan V. Pyrkov. The Newspaper and Other Markers of the Information World in the Novel Oblomov by Ivan Goncharov

138 Elena A. Fedorova. Experimental Novels by Nikolay Nekrasov and Feodor Dostoevsky in the Light of Ethnopoetics

150 Olga L. Fetisenko. Konstantin Leontiev's "Ascetic Philosophy": Thesaurus and Context

Textual Criticism

168 Aleksandr D. Ivinskiy. On Mikhail Muravyov's Poem The Painter (Based on Materials of Russian State Library and Institute of Russian Literature)

186 Marina A. Mozharova. “Thorough Bass”: on the History of a Musical Image in L. N. Tolstoy's Novel Anna Karenina

202 Veronika A. Makarova. Self-praise and Positive Self-assessment in Chekhov's Plays

Scientific Life

230 Viktor I. Shcherbakov. On "Works" by Nikolai Solovyov Being Prepared at the IWL RAS 


\section{Неизвестный рисунок Н. В. Гоголя}

Аннотация: Автором работы публикуется неизвестный рисунок Н. В. Гоголя, предлагается краткое его описание. Честь открытия рисунка принадлежит научному сотруднику Ульяновского Областного Краеведческого музея Татьяне Алексеевне Громовой. Рисунок Гоголя обнаружен в рукописных мемуарах симбирского помещика А. П. Родионова. Исходя из фактов жизни Гоголя, описанных исследователями, автор статьи определяет примерную датировку рисунка, а также передает его содержание. Гоголь возвращался из Германии в Россию, в Берлине он встретился с семьей Родионовых, далее часть пути они проехали вместе. Публикуемый рисунок был сделан писателем для А. П. Родионова, которому в ту пору было шесть лет. В связи с тем, что на рисунке изображено здание, совмещающее архитектурные элементы разных стилей, в данной работе отдельное внимание обращается на понимание Гоголем архитектуры, делаются отсылки к статье писателя «Об архитектуре нынешнего времени».

Ключевые слова: Н. В. Гоголь, заграничное путешествие, Родионовы, архивы, мемуары, рисунок, архитектура.

Информация об авторе: Сергей Николаевич Серягин, краевед, Союз краеведов Ульяновской области, ул. Радищева, д. 116 a, 432071 г. Ульяновск, Россия.

ORCID ID: https://orcid.org/0000-0002-6449-1211

E-mail: seryagin_sergei@mail.ru

Дата поступления статьи в редакиию: 02.03 .2021

Дата одобрения статьи рецензентами: 16.04 .2021

Дата публикации статьи: 28.06.2021

Для цитирования: Серягин С. Н. Неизвестный рисунок Н. В. Гоголя //

Два века русской классики. 2021. Т. 3, № 2. С. 6-15.

https://doi.org/10.22455/2686-7494-2021-3-2-6-15 


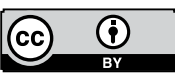

This is an open access article distributed under the Creative Commons Attribution 4.0 International (CC BY 4.0)
Dva veka russkoi klassiki, vol. 3, no. 2, 2021, pp. 6-15. ISSN 2686-7494 Two centuries of the Russian classics, vol. 3, no. 2, 2021, pp. 6-15. ISSN 2686-7494

Scientific Publication of Archival Documents

(C) 2021. Sergey N. Seryagin

Union of Local Historians of the Ulyanovsk Region Ulyanovsk, Russia

\title{
Unknown Drawing by Nikolay Gogol
}

\begin{abstract}
The author presents an unknown drawing by N. V. Gogol, and offers a brief description of it. The honor of discovering the drawing belongs to the researcher of the Ulyanovsk Regional Museum of Local Lore Tatiana Alekseevna Gromova. Gogol's drawing was found in the handwritten memoirs of the Siberian landowner A. P. Rodionov, which do not have any artistic value, but contain a representation of some historical events. Based on the facts of Gogol's life, described by researchers, the author of the article determines the approximate date of the drawing, and also conveys its content. Gogol was returning from Germany to Russia, in Berlin he moved in with the Rodionov family, then part of the way they rode together, and the published drawing was made by the writer for A.P. Rodionov, who at that time was six years old. Due to the fact that the figure shows a building that combines architectural elements of different styles, special attention is paid to Gogol's understanding of architecture, and references are made to his article "On the Architecture of the Present Time".
\end{abstract}

Keywords: N. V. Gogol, foreign travel, the Rodionovs, archives, memoirs, drawing, architecture.

Information about the author: Sergey N. Seryagin, local historian, Union of Local Historians of the Ulyanovsk region, Radishcheva St., 116 a, 432071 Ulyanovsk, Russia.

ORCID ID: https://orcid.org/0000-0002-6449-1211

E-mail: seryagin_sergei@mail.ru

Received: March 02, 2021

Approved after reviewing: April 16, 2021

Published: June 28, 2021

For citation: Seryagin, S. N. "Unknown Drawing by Nikolay Gogol." Dva veka russkoi klassiki, vol. 3, no. 2, 2021, pp. 6-15. (In Russ.)

https://doi.org/10.22455/2686-7494-2021-3-2-6-15 
Бесценно все, что имеет хоть малейшее отношение к личности и творчеству великого писателя. Артефакты, предметы быта, рукописи, черновики, наброски - все это тщательно собирается, регистрируется, систематизируется и бережно хранится в музеях и архивах, изучается исследователями и описывается в каталогах.

Цель данной статьи - введение в научный оборот неизвестного до сих пор рисунка Н. В. Гоголя и его краткое описание. Честь открытия публикуемого впервые рисунка принадлежит научному сотруднику (с 1978 г.) Ульяновского областного краеведческого музея им. И. А. Гончарова, заслуженному работнику культуры Ульяновской области Татьяне Алексеевне Громовой (1954-2020).

Восстановим краткую историю создания рисунка, кратко скажем о его адресате и возможном времени создания.

Просвещенная часть общества в силу ее малочисленности старалась держаться вместе и, познакомившись в 1839 г. с братьями Н. М. и П. М. Языковыми, Н. В. Гоголь сблизился и с их окружением. Сохранилось его письмо А. П. Ермоловой ${ }^{1}$, упоминается его знакомство с Е. П. Хованской ${ }^{2}$ и ее мужем, а также с семьей Родионовых [Черныш: 112].

Родство Родионовых с Языковыми было достаточно отдаленным, однако они находились в дружеских отношениях. Глава семейства, П. И. Родионов ${ }^{3}$ в переписке Николая Михайловича с братьями вы-

\footnotetext{
1 Александра Петровна Ермолова (1817-1888) - урожденная Ивашева (дочь П. Н. Ивашева, сестра Ел. П. Языковой и Ек. П. Хованской), жена А. И. Ермолова (1810-1892).

2 Екатерина Петровна Хованская (1811-1855), урожденная Ивашева, дочь Петра Никифоровича Ивашева и Веры Александровны Ивашевой, жена князя Юрия (Георгия) Сергеевича Хованского.

3 Петр Иванович Родионов (1803-1841), сын Дарьи Никифоровны Ивашевой (сестры П. Н. Ивашева), служил в лейб-гвардии конном полку, в 1818 г. вышел в отставку в звании штабс-ротмистра, в 1833-1835 гг. -
} 
Русская литература XVIII и XIX столетий

С. Н. Серягин. Неизвестный рисунок Н. В. Гоголя

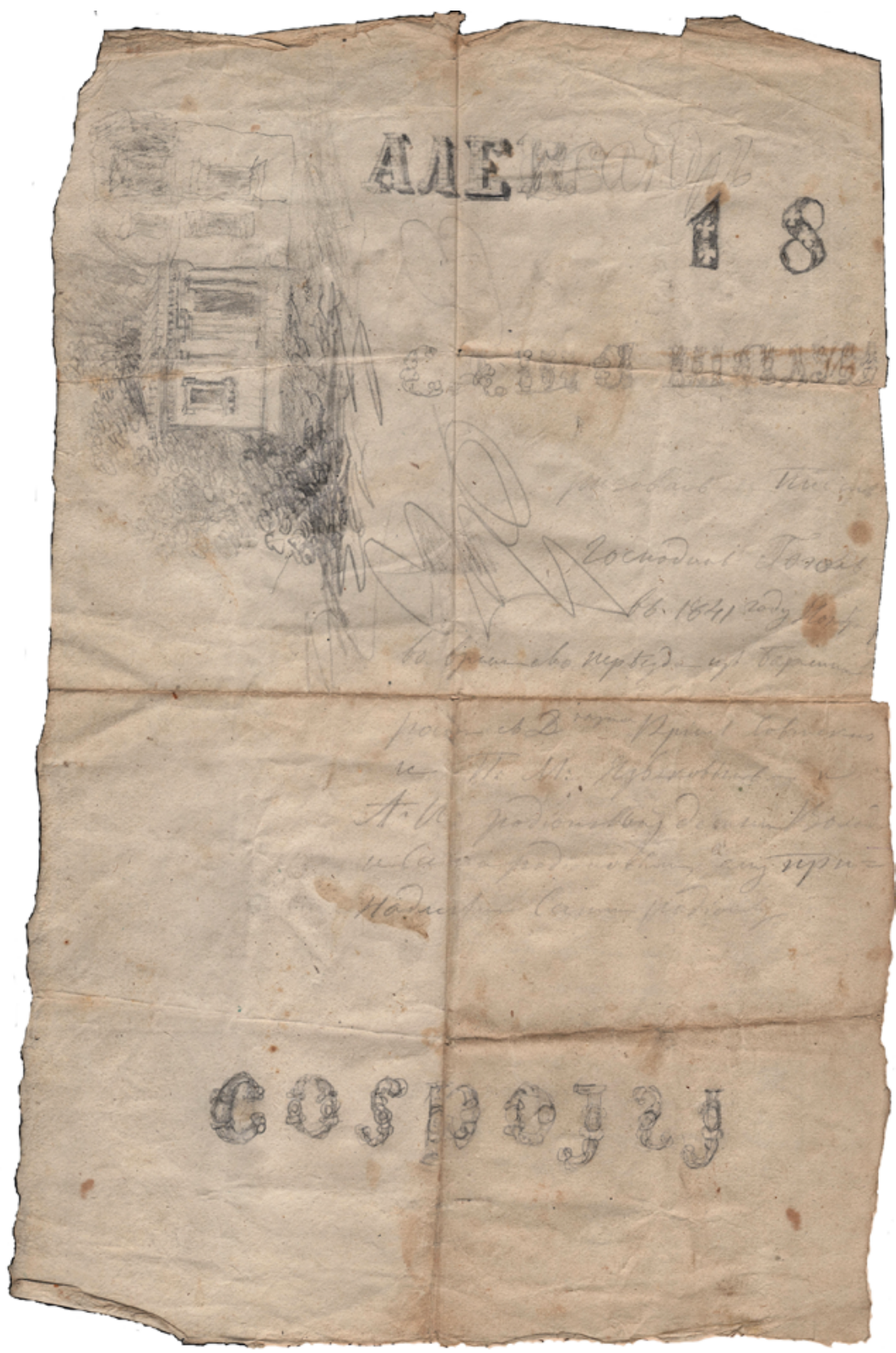


ступает как персонаж анекдотический: «Мне что-то не верится, чтобы Р. поднялся в такую даль. Думаю, что ежели он и выедет из Симбирска, то застрянет в Москве или Питере. Я Коппа беспокоил, и тот написал ему письмо, как к путному, а наш Петрик даже не поблагодарил его хотя бы словечком, полагая, вероятно, что советоваться с первым врачом Германии - то же, что с домашним, и что невежливость простительна больному и притом на таком расстоянии» [Шенрок: 621]. Однако в 1841 г. Родионов с семьей выехал в Европу для лечения, и в Берлине его жизненный путь оборвался. Возвращаться пришлось вдове А. И. Родионовой с малолетними детьми. Один из них - А. П. Родионов ${ }^{1}$ - оставил обширные мемуары, однако интерес они представляют весьма специфический. Это собрания сведений об окружающих, причем самого неприглядного характера - адюльтеры, непристойности и т. п., некоторые данные вызывают серьезные сомнения в достоверности.

Тем не менее мемуары А. П. Родионова имеют определенное научное значение. Как известно, осенью 1841 г. Н. В. Гоголь в сопровождении П. М. Языкова возвращался из Германии в Россию, в Берлине он встретился с семьей Родионовых, далее часть пути они проехали вместе. У А. П. Родионова сохранился рисунок, выполненный Н. В. Гоголем, с подписью В. И. Родионовой (тетки А. П. Родионова): «Рисовал писатель Господин Гоголь в 1841 году, Ноябрь, во время ево ${ }^{2}$ переезда из Берлина в Россию с Князем ${ }^{3}$ Юрием Хованским 4 и П. М. Языковым,

предводитель дворянства Карсунского уезда. Был женат первым браком на Вере Михайловне Наумовой, от которой имел пять сыновей и две дочери, с 1839 г. - на Анне Ивановне Коробковой [Ульяновская-Симбирская энциклопедия: 196].

1 Александр Петрович Родионов (1835-1899), выпускник училища правоведения, в 1854-1856 гг. служил в Межевом департаменте Сената, в 1873-1893 гг. - почетный мировой судья по Карсунскому уезду. Славился своей благотворительностью - попечитель Казанско-Богородицкой церкви и школы в Вешкайме, в 1892 г. открыл пекарню для раздачи крестьянам бесплатного хлеба и столовую для крестьянских детей на 120 человек. Был женат на М. П. Бестужевой (племяннице Н. М. Языкова) [Ульяновская-Симбирская энциклопедия: 196].

2 Так в автографе.

3 Слово: «Князем», — вписано вместо начатого: «[Д<етьми>]»

4 Князь Юрий Сергеевич Хованский (1806-1868), помещик Симбирской губернии, сын симбирского губернатора (в 1802-1808 гг.) князя С. Н. Хо- 
и А. И. Родионовой детьми Володей и Сашей, родственными ему. Принадлежит Саше Родионову» ${ }^{1}$

Объясняя появление рисунка, А. П. Родионов рассказывает, как всей семьей, с больным отцом, они направили свое «странствование в Берлин к славившемуся тогда доктору Шёнлейн<y>²»: «На моих впечатлениях, во время путешествия из России в Берлин, и обратно остановлюсь ненадолго. Да какие впечатления и могли быть у ребенка 6-ти лет!! Помню только, что на одной из станций (мьь ехали в карете) нам раздали по листу бумаги и по карандашу, и что ехавщий в одно время с ними из-за границы Н. В. Гоголь, нарисовал на моей бумаге какой-то домик (который я испортил своими каракулями) и написал отборным шрифтом: Саша шалун! Этот автограф Гоголя - до сих пор бережется у меня, конечно, не как предсказание (Гоголь - не был пророком), - акак воспоминание, весьма замутненное ${ }^{4}$, об нашем писателе! - Помню, что на одной из станиий, уже в Пруссии, мьь потеряли нашу девушку - Федосью, которую снова разыскали».

По данным исследователей [Виноградов 3: 584], 7 октября (н. ст.) 1841 г. путешественники были еще в Берлине, а уже 19 октября 1841 г. прибыли в Санкт-Петербург, т. е. датировка рисунка определяется данным временным диапазоном. В левом верхнем углу стандартного для того времени листа (чуть больше современного формата А5) автор рисунка изобразил пристрой к зданию (напоминающий алтарную апсиду, но судя по трубе, имеющий хозяйственное назначение). При этом само

ванского (1767-1817), муж Екатерины Петровны Ивашевой (1811-1855), дочери П. Н. Ивашева.

${ }^{1}$ ГАРФ. Ф. 1463. Оп. 1. Ед. 1119. Л. 12 об. Листок с рисунком Гоголя А. П. Родионов сопроводил примечанием: «Прилагаемый листок с рисунком Николая Васильевича Гоголя, сберегла <сбережен> моей тетушкой Варварой Ивановной Родионовой, которая сделала (карандашом) следующую надпись: “Рисовал писатель Господин Гоголь в 1841 г., Ноябрь, во время его переезда из Берлина в Россию с Княз<ем> Юрием Хованским и П. М. Языковым, А. И. Родионовой, детьми Володей и Сашей, ему принадлежит Саше Родионову” (ГАРФ. Ф. 1463. Оп. 1. Ед. 1119. Л. 13-14; текст примечания воспроизводит подпись В. И. Родионовой неточно).

2 Иоганн Лукас Шёнлейн (1793-1864), профессор патологии и терапии Берлинского университета, с 1839 г. лейб-медик Прусского короля.

3 Слова: «и обратно», - вписаны.

${ }^{4}$ В автографе описка: жамут $<$ не $>$ нное

${ }^{5}$ ГАРФ. Ф. 1463. ОП. 1. Ед. 1119. Л. 14. 
основное здание лишь приблизительно намечено. Сложно определить национальную специфику архитектуры. Отчасти в постройке заметны элементы русской архитектуры, в меньшей степени - немецкой и, возможно, итальянской. Соответственно нельзя сказать однозначно изображение это с натуры или, что более вероятно, представление или воспоминание автора (соответствие канонам и отсутствие каких-либо фантастических элементов позволяет утверждать, что это не фантазия в чистом виде). Заслуживает внимания статья Н. В. Гоголя «Об архитектуре нынешнего времени» (1835), посвященная этому вопросу: «Архитектура - тоже летопись мира: она говорит тогда, когда молчат уже и песни, и предания и когда уже ничто не говорит о погибшем народе. Пусть же она, хоть отрывками, является среди наших городов, чтобы при взгляде на нее осенила нас мысль о минувшей его жизни и погрузила бы нас в его быт, в его привычки и степень понимания и вызвала бы у нас благодарность за его существование, бывшее ступенью нашего собственного возвышения» [Гоголь 7: 271]. Это раннее произведение Н. В. Гоголя, но интерес к зодчеству он сохранял и в последующие годы. Для А. О. Смирновой-Россет, приехавшей в Рим в начале 1843 г. Гоголь разрабатывает подробные маршруты по городу, уделяя архитектуре самое пристальное внимание.

Скорее всего, этот рисунок, сделанный для ребенка, помимо возможного желания Гоголя представить мальчику какой-либо архитектурный образец стиля, был вызван воспоминанием писателя или представлял вариацию будущего замысла. Глубокий исследователь, много лет посвятивший изучению гоголевского творчества, протопресвитер В. В. Зеньковский справедливо отмечал: «Своеобразие Гоголя - в многопланности в его произведениях. Потому-то он и поддается легко перетолкованиям, - но при этом нередко улетучивается как раз то, что казалось наиболее бесспорным. <...> Почти всегда забывается, что художественное творчество Гоголя неотделимо от его идейных исканий и построений (как сам Гоголь не раз об этом говорил)» [Зеньковский: 205].

Косвенным подтверждением этому наблюдению служит совпадение некоторых деталей рисунка и рассуждений Гоголя в ранней статье. Так, в эссе об архитектуре автор неоднократно подчеркивает ее особо впечатляющий характер: «Зодчество грубее и вместе колоссальнее других искусств, и потому эффект его - в эффекте. <...> Белиз- 
на прямолинейной стены... выказываясь из-за темной гущи зелени, действительно хороша, потому что составляет контраст с облачным расположением дерева. Истинный эффект заключен в резкой противоположности» [Гоголь 7: 262]. Будто иллюстрируя эту мысль, строение на рисунке заслоняет собой буйство хаотичной растительности. При этом Н. В. Гоголь не сторонник унылого однообразия: «Как будто бы насильно старались истребить в душе благоговение и сделать человека равнодушным ко всему. Всем строениям городским стали давать со-

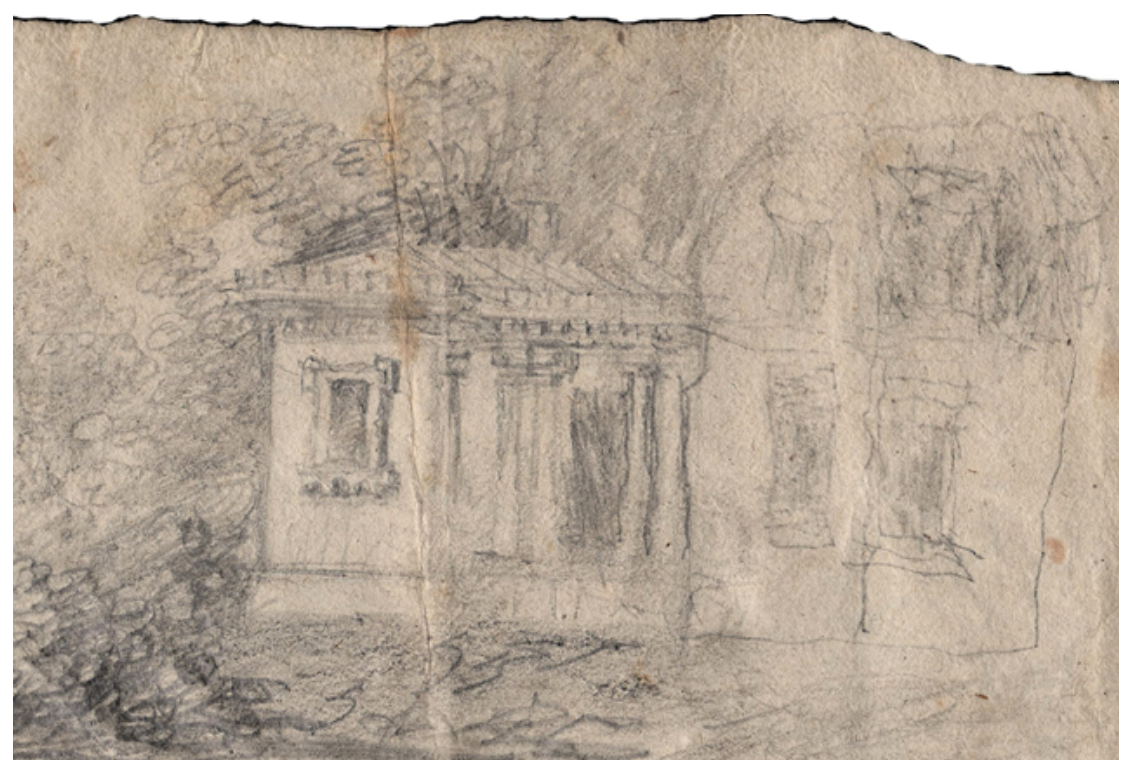

вершенно плоскую, простую форму. Дома старались делать как можно более похожими один на другого; но они более похожи были на сараи или казармы, нежели на веселые жилища людей» [Гоголь 7: 260]. И строение на рисунке нельзя назвать невзрачным, окно бокового фасада обрамлено наличником с массивным подоконником, а основная стена украшена пилястрами.

Трудно переоценить значение буквально каждой строчки Н. В. Гоголя. Архивисты соревнуются в том, чтобы каждый его новонайденный автограф внести в государственный реестр уникальных документов. В свою очередь исследователи в художественной мозаике писателя многое в полной мере еще не постигают. Каждая находка, дополни- 
тельный «штрих» дают возможность по-новому взглянуть на наследие художника, переосмыслить то, что известно, и сделать шаг к подлинно научному изучению биографии и творчества Н. В. Гоголя. В творческой лаборатории большого писателя «мелочей» практически не бывает. Даже при видимой незначительности каких-то деталей, фрагментов, всё может быть подчинено общему внутреннему замыслу и так или иначе вплетается в единое пространство творчества.

\section{Список литературы \\ Источники}

Гоголь Н. В. Об архитектуре нынешнего времени // Гоголь Н. В. Полн. собр. соч. и писем: в 17 т. (15 кн.) / сост., подгот. текстов и коммент. И. А. Виноградова, В. А. Воропаева. М.; Киев: Изд-во Московской Патриархии, 2009-2010. Т. 7. С. 255-273.

Ульяновская-Симбирская энциклопедия / ред. и сост. В. Н. Егоров. Ульяновск: Симбирская книга, 2004.592 с.

\section{Исследования}

Виноградов И. А. Летопись жизни и творчества Н. В. Гоголя (1809-1852). С родословной летописью (1405-1808): в 7 т. М.: ИМЛИ РАН, 2017-2018. Т. 3. 672 с.

Гиппиус В. В., Зеньковский В. В. Гоголь: Судьбы. Оценки. Воспоминания. ХIXХХ вв. СПб.: Logos, 1994. 344 с.

Черныши Г. Г. Неизвестное письмо Гоголя // Finitis duodecim lustris: сборник к 60-летию Ю. М. Лотмана. Таллин: ЭЭСТИ РААМАТ 1982. С. 109-116.

Шенрок В. И. Николай Михайлович Языков: биографический очерк // Вестник Европы. 1897. Т. 188. С. 597-651. 


\section{References}

Vinogradov, I. A. Letopis' zhizni i tvorchestva N. V. Gogolia (1809-1852). S rodoslovnoi letopis'iu (1405-1808): $v 7 t$. [Chronicle of Life and Work of N. V. Gogol (1809-1852). With a Pedigree Chronicle (1405-1808): in 7 vols.], vol. 3. Moscow, IWL RAS Publ., 2017-2018. pp. 255-273. (In Russ.)

Gippius, V. V., Zen'kovskii, V. V. Gogol': Sud'by. Otsenki. Vospominaniia. XIX-XX vv. [Gogol: Fates. Estimates. Memoirs. 19 $9^{\text {th }}-20^{\text {th }}$ Centuries]. St. Petersburg, Logos Publ., 1994. 344 p. (In Russ.)

Chernysh, G. G. "Neizvestnoe pis'mo Gogolia" ["Gogol's Unknown Letter"]. Finitis duodecim lustris: sbornik k 60-letiiu Iu. M. Lotmana [Finitis Duodecim Lustris: Collection to the 60th Anniversary of Yu. M. Lotman]. Tallin, EESTI RAAMAT Publ., 1982, pp. 109-116. (In Russ.)

Shenrok, V. I. "Nikolai Mikhailovich Iazykov: biograficheskii ocherk" ["Nikolai Mikhailovich Yazykov: Biographical Sketch"]. Vestnik Evropy, vol. 188, 1897, pp. 597-651. (In Russ.) 


\section{Основные черты имажинально-географической Германии в русских травелогах конца XVIII - первой половины XIX вв.}

Аннотация: В статье рассматриваются пространственные образы Германии, представленные в отечественных травелогах конца XVIII - начала XIX вв. Изученный с точки зрения семиотического подхода текстовый материал исследования составили произведения А. Т. Болотова, Д. П. Горихвостова, Д. И. Фонвизина, Н. М. Карамзина, С. А. Корсакова, В. К. Кюхельбекера, Ф. П. Лубяновского, И. П. Мятлева, М. П. Погодина, А. Я. Климова, В. Н. Зиновьева. В результате анализа указанного материала установлен набор основных черт, характеризующих имажинально-географическое пространство Германии. Его ядром выступает мотив упорядоченности, актуализирующийся в двух основных пространственных формах: рационально организованных в духе Просвещения локусах и идиллии, в основе которой лежат элементы аркадского мифа. С понятием порядка также связаны иные пространственные характеристики «лоскутного» пространства Германии в русской литературе рассматриваемого периода, включая мотивы аккуратности, чистоты, закрытости, узости, миниатюрности локусов. Подчеркивается амбивалентность восприятия русскими путешественниками немецкого пространства. Идиллическая Германия не только выступает объектом восхищения, но и иронически травестируется в ряде отечественных литературных текстов. Рационально организованное, маркированное цивилизованностью немецкое пространство как восхваляется за его удобство, так и критикуется в рамках его крайних сверхорганизованных дегуманизирующих форм.

Ключевье слова: пространство, имагология, Германия, интертекстуальность, травелог, мотив, сентиментализм, романтизм, русская литература.

Информация об авторе: Сергей Сергеевич Жданов, доктор филологических наук, доцент, Сибирский государственный университет геосистем и технологий, ул. Плахотного, 10, 630108 г. Новосибирск, Россия, Новосибирский государственный технический университет, пр-т Карла Маркса, 20, 630073 г. Новосибирск Россия, ORCID ID: https://orcid.org/0000-0002-8898-6497

E-mail: fstud2008@yandex.ru

Дата поступления статьи в редакиию: 24.01 .2021

Дата одобрения статьи рецензентами: 27.03 .2021

Дата публикации статьи: 28.06.2021

Для цитирования: Жданов С. С. Основные черты имажинальногеографической Германии в русских травелогах конца XVIII - первой половины XIX вв. // Два века русской классики. 2021. Т. 3, № 2. С. 16-39. https://doi.org/10.22455/2686-7494-2021-3-2-16-39 


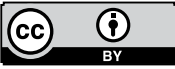

This is an open access article distributed under the Creative Commons Attribution

4.0 International (CC BY 4.0)
Dva veka russkoi klassiki, vol. 3, no. 2, 2021, pp. 16-39. ISSN 2686-7494

Two centuries of the Russian classics, vol. 3, no. 2, 2021, pp. 16-39. ISSN 2686-7494

Research Article

(C) 2021. Sergey S. Zhdanov Siberian State University of Geosystems and Technologies Novosibirsk State Technical University Novosibirsk, Russia

\section{Principal Features of the Imaginal-geographic Germany in Russian Travelogues of the Late $18^{\text {th }}-$ First Half of the $19^{\text {th }}$ Centuries}

Abstract: The paper deals with the spatial images of Germany represented in Russian travelogues of the late $18^{\text {th }}-$ first half of the $19^{\text {th }}$ centuries. The text corpus studied from a semiotic perspective consists of works by A. T. Bolotov, D. P. Gorikhvostov, D. I. Fonvizin, N. M. Karamzin, S. A. Korsakov, W. K. Küchelbecker, F. P. Lubyanovsky, I. P. Myatlev, M. P. Pogodin, A. Ya. Klimov, V. N. Zinovyev. A set of principal features representing the imaginal-geographic Germany is determined. The center of this set is the motif of orderliness actualizing in two images - a rationally organized space in the spirit of the Enlightenment and an idyll based on the Arcadian myth. The other spatial characteristics of the patched-up Germany are cleanness, accuracy, closeness, narrowness, miniatureness connected with the concept of order. The ambivalence of Russian travelers' perceiving the German loci is emphasized. The idyllic Germany is not only admired but also ironically travestied in Russian literature. The rationally organized, civilized German landscape is both praised for its comfortableness and criticized in the frames of its extreme forms for dehumanization.

Keywords: space, imagology, Germany, intertextuality, travelogue, motif, sentimentalism, romanticism, Russian literature.

Information about the author: Sergey S. Zhdanov, DSc in Philology, Associate Professor, 1) Siberian State University of Geosystems and Technologies, Plakhotnogo street, 10, 630108 Novosibirsk, Russia, 2) Novosibirsk State Technical University, Karl Marx Avenue, 20, 630073 Novosibirsk, Russia.

ORCID ID: https://orcid.org/0000-0002-8898-6497

E-mail: fstud2008@yandex.ru

Received: January 24, 2021

Approved after reviewing: March 27, 2021

Published: June 28, 2021

For citation: Zhdanov, S. S. "Principal Features of the Imaginal-geographic Germany in Russian Travelogues of the Late $18^{\text {th }}$ - First Half of the $19^{\text {th }}$ Centuries." Dva veka russkoi klassiki, vol. 3, no. 2, 2021, pp. 16-39. (In Russ.) https://doi.org/10.22455/2686-7494-2021-3-2-16-39 
The space of Germany in the Russian literature of the late $18^{\text {th }}-19^{\text {th }}$ centuries represents one of the spatial variations of Other in the Russian culture and can be analyzed as such from the perspective of imagology in literary studies. The latter can be determined as a field of literary studies that deals with "genesis, construction and broadening of images of Self and Other as well as images of nations" ${ }^{1}$ [Neumann B.: 2]. As J. Leersen writes, these images "....are tropes, commonplaces, obtain familiarity by dint of repetition and mutual resemblance..." and refer "not to empirical reality but to an intertext" [Leersen: 26]. From the imagological point of view spatial images are an important part of such heteroimages, "the place of an otherness" and "a viatic space" that "...is strongly affected by stereotyping" [Westphal: 112] and has consequently a set of characteristics repeating in many literary texts.

In terms of German spatial images in the Russian literature of the $19^{\text {th }}$ century, it should be emphasized that certain features of this imaginal-geographic Germany have been analyzed in the works by F. W. Neumann [Neumann F. W.] as well as S. V. Obolenskaya [Obolenskaya] or O. B. Lebedeva and A. S. Yanushkevich [Lebedeva, Yanushkevich]. However, the whole set of these spatial characteristics based on the analysis of the tradition in Russian travelogues of the late $18^{\text {th }}-19^{\text {th }}$ centuries hasn't been studied yet. This paper should help to fill the lacuna.

In addition, the text analysis in this paper is based on the position that the imaginal-geographic Germany is represented in the Russian literature of the $19^{\text {th }}$ century in relation to at least four basic narrative modalities. They can be notionally determined as sentimental (idyllic), romantic, travestied (ironic) and rather neutral ('naturalistic', 'slice-of-life' manner) but are often mixed with each other within particular texts.

The main feature of the anthropic space of Germany in Russian literature must be its high degree of order. It should be agreed to F. W. Neumann's conclusion that German space in Russian literature is represented as over-

${ }^{1}$ Hereinafter translated from German by the author. 
organized. German high-level cultivation is opposed in the literary texts to the wild essence of "the ancient Russian natural landscape" [Neumann F. W.: 120]. This German space is described as "shaped by people", "smoothed" and "fenced" [Neumann F. W.: 120], i.e. anthropic-organized, comfortable/undangerous and closed, respectively.

The motif of the German high orderliness is represented in different discourses of Russian literature. The authors of the pre-Karamzin epoch especially stress the regularity of the urban design in accordance with Enlightenment preferences. Thus, V. N. Zinovyev and D. I. Fonvizin mention the "regular" Mannheim: «Город новый, совсем регулярный...» [Zinovyev: 349]; «...лучше его я не видал в Германии: строение новое и регулярное» [Fonvizin 2: 455]. On the contrary, the Dresden palace is negatively assessed by V. N. Zinovyev as «строение весьма беспорядочное, ибо состоит в соединении шести или семи домов, которые не весьма хороший вид делают» [Zinovyev: 339].

D. I. Fonvizin's attention is also attracted by advances of the Western civilization making life more comfortable. They are the little of what draws the author's praise. For example, in Nürnberg D. I. Fonvizin describes «славный бронзовый фонтан, за который государыня предлагала тридцать тысяч рублей, но меньше пятидесяти не продают...» [Fonvizin 2: 514]. The author is delighted with public baths in Leipzig: «Устройство... бань отменно хорошо. <..> Чистота, услуга и удобности... неописаны. ...у нас нет такого приятного и для здоровья полезного установления» [Fonvizin 2: 509].

Orderliness, human-dimensionality of space are used in the sentimentalism texts by N. M. Karamzin and F. P. Lubyanovsky for constructing an idyllic German space particularly having Arcadian features in the image of Saxony [Zhdanov]. The nature is harmonically mixed here with the anthropic space, cultivated and gentled: «...Эльба и цепь высоких холмов, покрытых леском, из-за которого выставляются кровли рассеянных домиков и шпицы башен. <...> поля, обогащенные плодами; везде <...> зеленые ковры, усеянные цветами» [Karamzin: 56]; «...ты видишь не одни только места картинные, но несколько городов, несколько сот селений, одно другого лучше, одно другого счастливее» [Lubyanovsky 1: 23]. The same image of the cultivated land is presented in A. T. Bolotov's text that contains both pre-Karamzin and sentimentalism features and describes the idyll of the East Prussia: «Тут господствовал уже во всем иной порядок...: 
деревни были чистые, расположены и построены изрядным образом, дороги повсюду хорошие, и в низких местах повсюду мощеные, а инде возвышенные родом плотин и усаженные деревьями» [Bolotov 1: 466]. The Arcadian features also appears in later Russian travelogues, for example, in a fragment of V. K. Küchelbecker's romanticism text, representing spatial images of the Vistula region: «Необозримые пажити, светлые рощи, богатые луга, множество селений и городков на высоких берегах величественной прелестной реки...» [Küchelbecker: 11].

In addition, the image of the organized German space is connected in the sentimentalism texts with the concept of the enlightened monarchy. Therefore, the figures of Prussian kings and Saxon prince-electors become relevant in the travelogues at the turn of $19^{\text {th }}$ century. N. M. Karamzin's Russian traveler glorifies the Prussian king Friedrich Wilhelm I who is credited with many "deeds useful for the state" («дела, полезные для государства»): «Кто привлек в свое государство множество чужестранцев? Кто обогатил его мануфактурами, фабриками, искусствами? Кто населил Пруссию? Кто всегда отходил от войны? Кто отказывался от всех излишностей..., чтобы его подданные не терпели недостатка в нужном? Фридрих Вильгельм!» [Karamzin: 42]. F. P. Lubyanovsky also represents the Saxon prince-elector Friedrich August III as an enlightened monarch protecting his citizens' rights, "kind and peace-loving sovereign" («добрый и миролюбивый Государь»): «Курфирст у нас блюститель только законов: они столь же для него священны, сколько и для последнего из его подданных...» [Lubyanovsky 1: 25-26].

Saxony in whole is marked by F. P. Lubyanovsky as an incarnation of the organized enlightened monarchy combining advances of Reason and patriarchal idyllic features relating to the common good: «Образ правления нашего предоставляет нам самим право делать все те учреждения, кои по общему согласию могут быть признаны полезными...» [Lubyanovsky 1: 26]. The leading motif of this state is order. Saxony is regulated in the social sphere: «Между высоким и средним Дворянством, равно как и между всеми состояниями, проведена здесь черта, за которую никто не выходит: все в своем круге» [Lubyanovsky 1: 17-18]. Its fiscal field is also well-ordered: «Правительство... не упустило из виду ни одного предмета, который может умножить его доходы» [Lubyanovsky 1: 40], «...постоянный и твердый во всемпорядок, уверенность в употреблении сих сборов на общее благо, непоколебимое трудолюбие, трезвость и 
умеренность делают их [налоги. - С. Ж.] для всякого сносными» [Lubyanovsky $1: 40$ ]. The same order is noticed in economic management at whole: «...часть хозяйственная... в великом здесь устройстве» [Lubyanovsky 1: 36]. It is the space of the triumphal rationality: «Здесь без расчету никто ни полшага; все взвешенно и все измерено» [Lubyanovsky 1: 16]. All good changes are caused according to F. P. Lubyanovsky by the enlightened state policy civilizing the people: «Правительство сделало... для крестьян то, что только может быть полезнее...: распространило... просвещение» [Lubyanovsky 1: 38].

The idea of ordering space is closely connected with the motif of temperance in Russian travelogues dedicated to Germany. Not without some grain of the Russian empire aristocratism V. N. Zinovyev notices slipshod manners and simplicity in Prussian king's clothes («...вышел с палкой, <..> в синем мундире, закиданном табаком, и сапоги весьма красноваты. Трудно вообразить, что сей - тот, который против всей Европы оборонялся в одно время и всех... расщелкал; но сие есть действие привыкших глаз к роскоши» [Zinovyev: 338]) or laments the German avarice by making a banquet: «Обедал я... в Магдебурге <...> и его величество не расшибся в великолепии сих обедов, ибо больше четырех блюд не бывало, а десерт был пирожки» [Zinovyev: 345]. The level of luxuriance is what the Russian aristocrat stresses. On describing Leipzig he notices: «Перемену чрезвычайную нашел в Лейпциге. Роскошь чрезвычайно умножилась» [Zinovyev: 342 ]. That's why relatively humble conditions in the Saxon court cause to him ambivalent feelings. On the one part, he laments the boredom of the court life, lack of luxuriance: «Дворцовые, как и все прочие собрания, довольно скучны...», there are only "vestiges of the court splendor” («остатки великолепия двора» [Zinovyev: 340]). On the other part, V. N. Zinovyev recognizes former Saxon rulers' luxuriance was very ruinous for the country: «...земля еще не могла так скоро оправиться после правления двух королей, которые роскошью и глупой пышностью все, кажется, употребили, чтобы землю свою истощить...» [Zinovyev: 339]. In addition, Saxon current sovereign's temperance and carefulness with his territory is explained due to necessity to recover it after the Seven Years' War: «...король прусский всевозможные способы употребил в Семилетнюю войну, чтобы сию несчастную землю изнурить» [Zinovyev: 339].

In contrast with V. N. Zinovyev's text, Friedrich's simplicity in manners and style is rather positively stressed in A. Ya. Klimov's memoirs who forced- 
ly served in the Prussian army: «Он никогда себя великолепно не убирал, носил он без всяких балетов синий кафтан, шляпа без позументу с полимажем, сапог мало когда были мазаны. Трафило в походе, что он, не спрашивая постели, спал с солдатами, приобня, разостлав епанчу. $<\ldots>$ он иногда с солдатами разговаривал так, будто был им ровный товарищ» [Pokhozhdeniya praporschika Klimova: 45-46].

As stated by A. T. Bolotov, one of king's palaces in the East Prussia looks relatively poor and ordinary in comparison with houses of the Russian aristocracy: «...королевский дворец... составлял тогда очень небольшой и такой каменный домик, каких у нас в Москве несколько сот найтить можно...» [Bolotov 1: 711].

The Augsburgian patricians are more critically characterized by D. I. Fonvizin: «...больших господ нет. Первые люди, то есть патриции, не заслуживают человеческого имени» [Fonvizin 2: 515]. V. N. Zinovyev also notices reproachfully about citizens of Dresden: «...к сожалению, премалейшее расстояние между народом и дворянством нашел» [Zinovyev: 340].

In the sentimentalism discourse temperance has a different characterization in the frames of the Arcadian idyllic myth. Its part is a motif of "following the ideal of temperance (temperantia) trough curbing one's passions (moderatio animi)" [Thiergen: 75]. In N. M. Karamzin's laudation to Friedrich Wilhelm the latter is praised for his self-denial: «...отказывался от всех излишностей, для того, чтобы его подданные не терпели недостатка в нужном» [Karamzin: 42]. The same temperance is positively noticed by the Russian traveler in Berlin: «...богатые и знатные люди не расточают денег на суетную роскошь, и соблюдают строгую экономию в столе, платье, экипаже и проч.» [Karamzin: 48].

This motif is also typical for F. P. Lubyanovsky's representation of Dresden: «...роскошь не в вышней степени. Осторожная бережливость отъемлет ли у здешних жителей охоту к ея блеску и удовольствиям, или заставляет против воли от них отказываться» [Lubyanovsky 1: 16]; «Не удавалось мне тут видеть ни весьма богатых, ни весьма бедных людей» [Lubyanovsky 1: 32]. Like V. N. Zinoviev, F. P. Lubyanovsky compares old and new Saxon arrangements in the context of the motif of temperance («Если обратиться к прошедшему времени, когда здесь роскошь $<\ldots>$ блеск свой поддерживала чужим имуществом <...>, то нельзя не отдать справедливости здешнего Правительства, которое <...> 
решилось отречься от прежних правил <...> Умеренность заступила место роскоши...» [Lubyanovsky 1: 36]) and connects it with sequences of the Seven Years' War: «...бедствия, навлеченные семилетнею войною, были... великим уроком умеренности, которая обращает все наше внимание на внутреннее благоустройство и обогащение Государства» [Lubyanovsky 1: 24].

Even the weather in Saxony is described as temperate: «В Саксонии климат постояннее; зима там столь была умерена, что я в одном сюртуке всякий день ходил гулять загород» [Lubyanovsky 1: 123].

But what is marked rather positively on the macroscale, i.e. on the level of state and nature, can be represented ironically on the microscale of a person. Thus, Germans in the Russian travelogues are described neither extremely bad nor very good. They are often mid-level and very moderate from Russian authors' point of view. Temperance in this context can transform to ordinariness: «Холодный нрав здешних жителей... мало сроден к великим и сильным впечатлениям...» [Lubyanovsky 1: 21-22]; «Здесь во всем столько меры и весу, что самая чувствительность должна покоряться сему закону» [Lubyanovsky 1: 22]. Saxons in F. P. Lubyanovsky's travelogue tend to a peaceful life that is, however, rather monotonous and has nothing to do with great challenges: «...нрав здешних жителей <...> не ищет тех добродетелей, где требуется некоторый род восторга, и останавливается на тех, кои могут не нарушать его покоя» [Lubyanovsky 1: 21-22]. The people of Saxony seem to have no sense of worldly pleasures, do not show their emotions and virtues of friendship and charity: «Я не приметил в здешних крестьянах того добродушия, коим наши всегда отличались; ни наклонности к благотворению...; ни готовности к услугам. < ...> Нет между ними того гостеприимства, которое у нас... мы находим» [Lubyanovsky 1: 34]). In the same way, A. T. Bolotov panegyrizes the kindness of his landlords, the Swiss living in Königsberg, opposing their manners to the Prussian cold nature: «...дивился, что нашел посреди Кенигсберга таких добрых людей. Но удивление мое скоро исчезло, когда я узнал, что старики мои были не природные прусские жители, а уроженцы <...> Швейцарии» [Bolotov 1: 891].

On the whole, the German life is described as a reiteration of one and the same happenings strictly controlled: «...здесь для купцов ограничен род торговли тот самый, какой кто себе однажды навсегда избрал <..> Торговля и все ремесла... здесь наследственны: от отца переходят они 
к сыну» [Lubyanovsky 1: 42]. Even the life of the Saxon prince is marked with sameness and statics fixing thereby the achronic character of the locus: «...столько единообразен в своей жизни, что сегодня я могу смело сказать, какое платье наденет он в сей самый день следующего года...» [Lubyanovsky 1: 25].

N. M. Karamzin's attitude towards the German temperance is ambivalent. On the one hand, the Russian traveler praises Berliners' sparing style of life. On the other hand, he is rather negatively surprised with its extreme examples: «Я видел старика $\Phi^{* *}$ едущего верхом на такой лошади, на которой бы, может быть, и я постыдился ехать по городу, и в таком кафтане, который сшит конечно в первой половине текущего столетия» [Karamzin: 40].

Later, in the context of the romanticism discourse, the Saxon temperance is also represented with a dramatic irony in V. K. Küchelbecker's travelogue of the early 1820-ies when describing curiosity seekers: «Саксонец вообще в таком случае тих, молчалив, внимателен, глубокомыслен; <...> смотрели на госпожу Сталь и на морского льва, на великаншу и на всех присутствующих важно, пристально, спокойно, с величественною осанкою» [Küchelbecker: 16]. However, Saxony is basically labeled here idyllic, in other words similar to the image of the locus within the sentimentalism discourse («Все долины, холмы и скаты усеяны бесчисленным множеством селений, деревень, городов...» [Küchelbecker: 13]. The image of the tolerant Saxon ruler is in the same way as in the sentimentalism texts connected with the concept of the enlightened monarchy: «В Саксонии король не обращает внимания на безделицы, которые сами по себе никак не могут быть опасными для правителя...» [Küchelbecker: 25]. The simplicity in Friedrich's manners is represented with the image of his last unpretentious resting place: «...он в простом гробе с свинцовою обшивкою...» [Küchelbecker: 11].

Along with the sentimentalism and romanticism discourses some Russian travelogues of the first half of $19^{26}$

century describing Germany can be referenced as the 'slice-of-life' narrative that tends to 'realistic' describing the German territories and their people. But even in these travelogues of the 1830-40-ies there are features of the German spatial images which are similar to the previous literary tradition.

German unwillingness to change is referred by D.P. Gorikhvostov in the scene of visiting F. G. Klopstock's house. The Russian traveler meets here 
poet's sister who has been living in one and the same residence for more than fifty years what is according to the author "a striking example of the German consistency” («разительный пример Немецкого постоянства») [Gorikhvostov 2: 313].

M. P. Pogodin in the text of the 40-ies uses the motif of temperance when describing Germany the image of which ballances between the patriarchy of the agrarian idyll and the rationality of the Modern age. These mixed concepts are represented in the motives of the cultivated Prussian land («Поля все возделаны - загляденье! Едешь как по саду. Везде видна забота, попечение» [Pogodin 1: 100]) and the cheapness of the German temperate style of life («Немецких учителей нельзя сравнивать с нашими: нужды их несравненно меньше; жить у них гораздо дешевле...» [Pogodin 1: 102]). As in the sentimentalism travelogues, different German stratas (even the highest) are marked by M. P. Pogodin with the motif of temperance. He particularly describes the Prussian prince walking in Marienbad: «... он <..> в соломенной шляпе, в черном сюртуке... прогуливался наравне со всеми, как бы самый последний гражданин. Бережливость и простота Великого Фридриха... продолжают украшать его потомство!» [Pogodin 4: 73].

The author rather positively marks in many cases German bureaucrats' sense of duty, their ability to carry out the order, punctuality, hard-working nature («точность, исправность, добросовестность, трудолюбие») what often lacks Russian government officials but the latter have more "poetry", i.e. imagination, in contrast with 'prosaical' Germans [Pogodin 4: 78].

In addition, M. P. Pogodin stresses that even German little towns are the loci of civilization in keeping with the spirit of the Enlightenment: «В самом последнем городишке есть публичная библиотека, есть книжная лавка, есть ученое образованное общество» [Pogodin 1: 102]. The space of German hotels is also marked with order and comfort: «Немецкие гостиницы устроены отлично: чистота, порядок, точность и определенность, заслуживают всякой похвалы» [Pogodin 1: 88]. The Prussian postal service is compared by M. P. Pogodin to a high-quality clock mechanism that actualizes the meaning of rational organizing the German space in the Russian literature: «Прусская почта устроена превосходно <..> Все как по заведенным часам» [Pogodin 1: 100].

It can be seen from the fragments mentioned above that the representations of Germany permanently balance between the spatial images of idyll 
or rationality and pragmatism. The sphere related with the latter concept tends to get marked as place of Philistines, rational bourgeois. That actualizes two controversy emotional expressions of Russian travelers - admiration and (more or less slight) irony. By the way, the image of the 'prosaical' Germany should be based on the concept of the strict dichotomy ${ }^{1}$ between the spiritual and practical parts of life determinative for the German nature from Russian authors' point of view. As mentioned for example in P. V. Chichagov's notes, «они [i.e. Germans] знают, что благо часто бывает вещественное; высокое почти всегда воображаемое, поэтому-то они и не примешивают никогда своей метафизики к делам житейским, а, следовательно, - и к делам государственным» [Chichagov: 26].

However, the overorganized, highly controlled locus can also be repugnant. Germany in some episodes of the Russian travelogues is labeled antiidyll, repression mechanism. In the most cases this brutal site of the German space is Prussia. As for example, Berlin and Potsdam are marked in V. N. Zinovyev's text as prison-places for the own Prussian soldiers: «...состояние солдат самое несчастливейшее: и в Берлине, и в Потсдаме нарочно стены возведены, чтобы беглых чрез оные удерживать, часовые так часто расставлены около оных, что, кажется, возможности нет бежать...» [Zinovyev: 337].

The image of the city-prison is represented in the highest degree in A. Ya. Klimov's travelogue as the author was actually imprisoned in Prussia as a soldier who had been captured at fist by Prussians, claimed then as fallen in battle and forced to serve during 30 years in the Prussian army. After killing his brutal sergeant-major by accident the author describes his desperation because of impossibility to flee to Saxony: «Я уже думал бежать из Берлина, но куда было можно? <...> Граница ж была весьма крепко утверждена егерями. Да из Берлина выйти было невозможно за крепким и частым

\footnotetext{
1 The variant of this dichotomy is also presented in N. V. Gogol's letters. Here, the writer differs the spiritual Germany that had arisen in his imagination inspired by German philosophy and literature before he visited the land («...в это время <..> я смешивал немецкую ученость, немецкую философию и литературу с немцами. <..> немецкая поэзия далеко уносила меня тогда в даль, и мне нравилось тогда ее совершенное отдаление от жизни и существенности» [Gogol' 11:251]) and the 'prosaical' Germany of his later real travel («Я... в ней ничего не видел, кроме скучных табльдотов и вечных, на одно и то же лицо состряпанных кельнеров...» [Gogol' 11: 187]).
} 
караулом. Ибо Берлин с одной стороны <..> окружен был высокою каменною стеною, а с другой стороны <..> - палисадами, где стоял весьма часто караул...» [Pokhozhdeniya praporschika Klimova: 53]. Additionally, A. Ya. Klimov mentions that all the Russian war prisoners were kept in barracks during Prince Pavel's visiting Prussia due to prevent their meeting him: «...увидели себя опять под игом прусским, потому что... король прусский приказал нас всех, находящихся в полку россиян, загнать под крепкий караул...» [Pokhozhdeniya praporschika Klimova: 73-75].

Moreover, D. I. Fonvizin marks the city Frankfurt-am-Main as a gloomy prison: «...мрачность в нем самая ужасная» [Fonvizin 2: 506]; «Надобно в нем родиться или очень долго жить, чтоб привыкнуть к такой тюрьме» [Fonvizin 2: 507].

As for the sentimentalism discourse. it must be kept in mind that the image of the regular state, i.e. ordered and rationally organized, is destined here to be ambivalent. The patriarchal idyll of Arcadia transferred from the field of mythopoetics is never completely congruent even in the sentimentalism travelogues with the 'real' Germany examined and described by the Russian travelers. Consequently, dualization of the German spatial imaginariness is unavoidable to balance between the idyllic utopia and the rationalized dystopia of the state-mechanism that manages people's lives. There is no room for violence in the idyll by virtue of its nature that's why even the sentimental narrative representing the German reality has to push boundaries of the idyll. In contrast, the pre-Karamzin travelogues do not deal with the 'narrative' problem of combining idyllic and antiidyllic elements, the ideal model of the enlightened monarchy and the representation of the real state.

Although the antiidyllic features of the German space in the sentimentalism texts are rather softened, they are actualized in some images of German bureaucracy connected with the motif of spatial ordering. Prussian Officials' parvanimity and punctuality are mentioned by Karamzin's Russian traveler who mocks so called "Prussian examinations" («прусские допросы») when entering and leaving places: «Во всяком городке и местечке останавливают проезжих при въезде и выезде, и спрашивают, кто, откуда и куда едет?» [Karamzin: 31]. The highest point of this motif is actualized in the Berlin space. At first, a sergeant at the city gate interrogates arrivals: «Кто вы? Откуда едете? За чем приехали в Берлин? Где будете жить? Долго ли здесь пробудете? Куда поедете из Берлина?». that provokes Russian traveler's ironic remark about "curiosity of the local government" («любопытство 
здешнего Правительства» [Karamzin: 33]. Then, the innkeeper in Berlin makes the Russian traveler fill up a form with the same questions and an extra-question «в какия ворота вы въехали?» what causes in return an ironic likening between the Prussian capital and a city under siege: «...какая осторожность! Разве Берлин в осаде?» [Karamzin: 35]. In such a way, the urban space is marked with the features of a barrack ${ }^{1}$ and a registry at the same time. Everything here is to be controlled and registered. The information received from newcomers is published in newspapers after a day. Finally, the motif of the "Prussian examinations" is stated in representation of Potsdam, the former residence of Friedrich the Great though in a softened form: «У ворот записали наши имена; однакожь в рассуждении допросов ныне нет уже такой строгости, как прежде. Покойный Король, живучи в Потсдаме, хотел знать обо всех приезжих» [Karamzin: 41].

F. P. Lubyanovsky, who pays far more attention in comparison with N. M. Karamzin to representing German social-political and economical order, emphasizes mechanisms of real ordering the space by stating social frameworks out of which the actors may not go. It can be illustrated with an example of fiscal restrictions from the Saxon economics: «Здесь $<\ldots>$ я не могу продать в городе даже птицы, прежде нежели заплачу на заставе один из тех грошей, кои надеюсь еще за нее выручить» [Lubyanovsky 1: 41]. As stated by the author, Germans appear to be less free than Russian people in commerce: «В благословенном Русском Царстве каждый, кто хочет, свободно все продает и покупает» [Lubyanovsky 1: 40-41]. N. M. Karamzin mentions in a similar way that the Prussian king has curtailed freedom of commerce for Danzig belittling its prosperity and independence: «...блеск сего города померк с некоторого времени. Торговля, любящая свободу, более и более сжимается и упадает от теснящей руки сильного» [Karamzin: 26].

A. T. Bolotov reveals that the idyllic peace and decency at public celebrations in Königsberg is at least partially determined by not citizens' goodwill but the fear of police: «Наша полиция наблюдает весьма строго то, чтоб ничего подобного... не происходило. $<\ldots>$ кому вздумается чтонибудь непристойное и неприличное предприять, тотчас под руки, и выведут со стыдом вон и вытолкают в двери, кто 6 он таков ни был» [Bolotov 1: 832].

${ }^{1}$ Prussia at whole is marked as a military space and a space of violence in many Russian travelogues of the epoch. 
The romanticist V. K. Küchelbecker labels Germany by and large the place of freedom in the post-Napoleonic Europe but determines in an extremely emotional manner some "humiliating and slavish" («унизительные и рабские») habits of Dresden like using sedan chairs and making orphans sing grim songs about death, judgement and demolition in the empty evening streets of the city [Küchelbecker: 25].

There are more ironic remarks about German orders in the later Russian literature which can be referred to the post-romanticism, travestying and 'slice-of-life' discourses. German excessive appreciation for keeping order with the help of police is stated in I. P. Myatlev's humorous poem dedicated to travelling of the fictional character Mme Kurdyukova: «...славных полицейских подобрали... Ле режим мюнисипаль только в городе годится, но когда распространится в государстве, - се бини! Ты оглобли поверни...» [Myatlev 1: 64].

The common place of the Russian travelogues describing Germany is invectives against German pedantic customs officers. D. P. Gorikhvostov mentions "strict customs control" in the Prussian boudaries: «...медленный доступ таможенных надсмотрщиков и деспотическая их власть перерывать имение у проезжающих - несносны...» [Gorikhvostov 2: 381-382]. Kurdyukova laments officers' brutality with her luggage: «Здесь мой бедный чемодан весь расшарят, раскидают...» [Myatlev 1: 49]. Harshness of the customs office in Dresden is stated in N. A. Korsakov's text: «Осмотр был самый строгий. ... не только вскрыли ящики, но и из обертки все вынули» [Korsakov: 91]. There is also the scene with a pedantic customs officer slowing down the traveler in M. P. Pogodib's travelogue: «Немец принялся читать артикул с чувством, с толком, с расстановкой, делая ударение на всяком знаке препинаний, три товарища следовали за ним глазами и телодвижениями, повторяя в полголоса последние слова...» [Pogodin 1: 107].

The same painful pedantry as addiction to ordering the space is mentioned by the author in the episode when the traveler asks Germans which way to go: «Немцы рассказывают о дороге $<\ldots .>$ совершенно отличным образом от Русских: они опишут вам ее всю, начиная от того места, с которого вы спрашиваете, и до того, куда хотите прийти, целую Историю, или лучше Географию» [Pogodin 4: 56]. By the way, Germans order the space (with giving the route scheme) not only in their speech but also in imagination, i.e. twice: «Немец непременно остановится, пройдет 
сам в воображении всю дорогу...» [Pogodin 4: 56]. They do it in good faith without noticing their order makes another person suffer because of their pedantry: «Эти добрые люди мучили меня столько, что я решился их не спрашивать, дабы не слушать их длинных рассказов» [Pogodin 4: 57].

As you can see, the motif of order seems to be basic for representing the German space in the Russian literature of the end of $18^{\text {th }}-$ the first half of the $19^{\text {th }}$ centuries though it gets various interpretations - positive and negative - in dependence to authors' attitudes.

Besides, there are several other features typical for this space. One of them is the motif of cleanness/accuracy/trimness that is connected with orderliness of the German loci. The cleanness of German places is emphasized in D. I. Fonvizin's travelogue: «...город недурен и чистехонек» [Fonvizin 2: 506] (Marienwerder); «Чистота, услуга и удобности <...> неописаны» [Fonvizin 2: 509] (Leipzig); «...стали в трактире, в котором безмерная чистота и опрятности привели нас в удивление. Все улицы и дома здешние так чисты, что уже походит на аффектацию» [Fonvizin 2: 511] (Nürnberg).

The same motif characterizes the German space in Karamzin's travelogue («Мы пошли в трактир, где, кроме хозяина и гостей, все было довольно чисто» [Karamzin: 25] (Elbing); «Отменная чистота стекол украшает вид их [i.e. houses]» [Karamzin: 27] (Danzig); «Комната у меня чиста и светла...» [Karamzin: 60] (Memel)) as well in F. P. Lubyanovsky's text («Чистота и опрятность даже в бедных домах...» [Lubyanovsky 1: 31] (Silesia); «Город <...> по чистоте <...> весьма примечателен» [Lubyanovsky 1: 85] (Hernhut); «Здесь [i.e. in Bohemia] по селениям я не нашел той опрятности, того порядку и той чистоты, коими столь любовался в Саксонии» [Lubyanovsky 1: 107]) and A. T. Bolotov's memoirs [«...деревни были чистые, расположены и построены изрядным образом...» [Bolotov 1: 466] (East Prussia), «...повсюду господствовал порядок и везде видна была чистота и опрятность» [Bolotov 1: 639] (Gumbinnen)].

The motif of cleanness is also represented in Russian travelogues of the 1830-ies - 1840-ies. I. P. Myatlev marks Manheim as "neat clean" («чистенький») [Myatlev 1: 141] and Frankfurt as "accurate, as neat as a new pin” («аккуратный, как с иголочки») [Myatlev 1: 118]. N.A. Korsakov uses this motif describing an asylum in Hamburg. Cleanness prevails here in kitchens and lunchrooms: «...чистое столовое белье, оловянные миски и кружки кажутся серебряными» [Korsakov: 23]. M. P. Pogodin combines 
the motives of orderliness, rationality, comfort and cleanness in the images of German hotels: «Немецкие гостиницы устроены отлично: чистота, порядок, точность и определенность, заслуживают всякой похвалы» [Pogodin 1: 88]. Herewith, the active character of the German nation is stressed because of which the nature become anthropic, is transformed in a comfortable locus marked with the motif of cleanness. The latter is also represented in the image of clean and comfortable pathways in the Marienbad area. As stated by the author, cleanness is a natural element of Germanness but not Russianness. According to M. P. Pogodin's ironic remark, if hardly ten Germans are enough to keep these pathways clean it would require more than two hundred people in Russia: «...по-нашему надо бы приставить к ним сотни две работников, дюжины две садовников, и несколько чиновников, под начальством Директора, в великолепной квартире...» [Pogodin 4: 66-67]. According to the author, cleanness in Russia is spread forcedly and top-down while Germans keep order without special control and heavy costs.

The motif of orderliness is also closely connected with the motif of closeness typical for representing German loci in the Russian literature. The images of prison-cities and 'besieged-like' cities with the boundaries strictly controlled were mentioned above in the paper. However, there are not only 'military' or 'prisonous' connotations in representations of the motif. Germans in the Russian texts are often represented to prefer sealing themselves off from the outer world that is dangerous and non-ordered. N. M. Karamzin's Russian traveler praises "sizeable gardens" in Köningsberg allowing to rest in nature without leaving the city [Karamzin: 23]. The Königsbergers from A. T. Bolotov's memoirs also prefer resting in these inner gardens or walking in near neighborhood of the city in contrast with narrator's Russian casual friends making once a dangerous boat ride for a picnic.

F. P. Lubyanovsky mentions about a habit in Dresden to close the city gates at hours of preaching [Lubyanovsky 1: 19]. Additionally, he informs that all the gates in Leipzig except one are closed at 9 p.m. due to keep watch on cityfolk's moral, i.e. to order people's lives: «...строгая здешняя Дума заметила между... жителями слишком уж явное расслабление в нравах. Гулянье за городом и особливо ночью было к тому для всех выгодным убежищем. Дума велела запирать в 9 часов все городские ворота, оставляя только одни для проходящих; но и тут надобно заплатить грош, когда кто желает войти или выйти» [Lubyanovsky 1: 59-60]. N. M. Karamzin’s Rus- 
sian traveler gets to know this rule of Leipzig. After having spent his time in a tavern out of the city till the midnight, he has to pay for opening the gate: «Таков закон в Лейпциге: или возвращайся в город ранее, или плати штраф» [Karamzin: 68]. The same thing is mentioned by N. A. Korsakov in a Hamburg episode of his journey: «...становится поздно, и по прибытии 9 час. вечера вы заплатите 4 шил. 932 к. штрафу» [Korsakov: 20].

Orderliness and closeness of the German space is additionally connected to the motif of the spatial limitation characterizing German loci in the Russian texts. It should be generally agreed with G. D. Gachev's statement about narrowness of the German world where "...there is Nähe all the time..., there is no Ferne - expanse that is always present in Russia"' [Gachev: 243]. That's why the vertical of the Height and the Depth dominates the horizontal of the Distance and the Expanse in the imaginal Germany. Of course, there are images of German open and wide spaces in the analyzed Russian travelogues but they as a rule belong to representing wild nature space which is seen by a character, single and foreign in the German chronotope.

This horizontal limitation can be actualized as narrowness, tightness what is typical for images of medieval-like German urban places with their gothic architecture style. Of course, these features can't be labelled unique, characterized only for Germany but they are perceived by the Russian authors as differentiating between the Russian and German space. D. I. Fonvizin describes Königsberg in his usual critical manner: «Улицы узкие, дома высокие, набиты немцами, у которых рожи по аршину» [Fonvizin 2: 505-506]. The same is stressed by the writer in the image of Nürnberg with its "narrow streets" and "numerous people" (reference to a cramped area): « ...считают в нем до восьмисот улиц, что и не удивительно, если называют улицами все по горам закоулки, какие на сто шагов обыкновенно встречаются» [Fonvizin 2: 512].

The narrowness of the German urban space is mentioned in N. M. Karamzin's travelogue: «Дрезден едва ли уступает Берлину в огромности домов; но только улицы здесь гораздо теснее» [Karamzin: 51]; «В городе улицы узки, хороших домов мало...» (Mainz) [Karamzin: 90]. A. T. Bolotov seems to prefer wider new streets of Königsberg to narrow ones in its historical center: «...в тесных городских улицах <...> нередко бывает... дурной запах и духота, заражающая воздух, и от того нижние покои обыкновенно бывают очень скучны и от узкости улиц темны» [Bolotov 1: 714]. “Great

${ }^{1}$ Hereinafter translated from Russian by the author. 
multitude of people" («многолюдство») [Lubyanovsky 1: 36] combined in Saxony with "shortage of land" («недостаток земли» [Lubyanovsky 1:37] is noticed by F. P. Lubyanovsky. The author also combines the motif of orderliness with the motif of the spatial limitation in his representation of the Saxon space: «...в такой области, которой значащую часть можешь глазами измерить сверху высокой башни, легко удержать во всем порядок и постоянным надзором отвратить несчастные происшествия» [Lubyanovsky 1: 43]. As you can see, the vertical axe (high tower\} dominates the horizontal of the German landscape ordering it.

The half-German Narva from V. K. Kyuchelbeker's travelogue is also marked by the narrowness and antithesized to the spacious Saint Petersburg: «Нарва после С.-Петербурга производит на душу странное впечатление. Улицы, и сверх того главные, уже нашего грязного переулка...» [Küchelbecker: 7].

Bonn is mentioned in I. P. Myatlev's poem as "small and narrow town" («город маленький и тесный») [Myatlev 1: 94]. The space of Hamburg beyond the boundaries of the rich district is marked with backstreets («закоулки») and narrowness («теснота») [Myatlev 1: 33]. N. A. Korsakov stresses the same elements in the image of Lübeck: «сплошные, один к другому пристроенные дома», «узкие переулки» [Korsakov: 14]. M. P. Pogodin mentions in Frankfurt "many old narrow streets with ramshackle buildings” («много старых узких улиц с полуразваленными домами») [Pogodin 4: 50].

It should be admitted that the narrowness of the German space is not always marked negatively by the travelers used to the Russian expanse ${ }^{1}$. It can be in some cases a feature of the very positive idyllic space. Narrowness and heavy population density of Germany refers to the comfortable civilized anthropic loci, the human presence in landscape, the space of life. For example, it is stressed by A. T. Bolotiv ("Какое великое множество деревень представилось тогда вдруг моему зрелищу! Истинно все поля были ими власно как усеяны!” [Bolotov 1: 714]), F. P. Lubyanovsky («...вдруг усматриваю в отдаленности... цепь гор, виноградными лозами покрытых, городские башни и множество селений» [Luby-

${ }^{1}$ Cf. an image of the Russian expanded urban space represented by a German traveler that is an antipode of the German narrow urban place in the Russian texts: "There can be 10 times more houses in the space occupied by a German town" [Potapenko: 45]. 
anovsky 1: 28-29], V. K. Kyuchel'beker («Все долины, холмы и скаты усеяны бесчисленным множеством селений, деревень, городов - все здесь кипит жизнью» [Küchelbecker: 13].

The German loci in the Russian travelogues are often represented as not only narrow but also miniature. It is actualized with using diminutives which have a hypocoristic or derogative senses of word in accordance with author's attitude to Germany. D. I. Fonvizin represents the spatial images of the land with critical expressions like «землишка» Saxony [Fonvizin 2: 511], «деревнишки» Sarkau and Rossitten [Fonvizin 2: 505], «городки» Friedland, Lukau and Schleiz [Fonvizin 2: 506, 507, 511] and even an oxymoronic word-combination «большой городок» Marienwerder [Fonvizin 2: 506]. It should be connected with the concept of the German space as something small in comparison with the Russian expanse. Diminutiveness of particular parts within the patched-up Germany is stressed in the fragment where the size of territories marks metonymically their rulers ("small princes"): «...ехал я по немецким княжествам: что ни шаг, то государство. Я видел Ганау, Майнц, Фульду, Саксен-Готу, Эйзенах и несколько княжеств мелких принцев» [Fonvizin 2: 455].

The opposition "Russian expanse - German miniatureness" in the spatial context is immanently presented in V. N. Zinovyev's ironic reasoning about German princesses of small lands («княгинюшки») and Catherine the Great who had been the princess of Anhalt-Zerbst but became the Empress of Russia: «...прискорбно должно быть немецким княгинюшкам, которые государыню как принцессу Цербстскую знали, и теперь видят, что она судьбу Европы решает» [Zinovyev: 348]. In addition, V. N. Zinovyev determines the prince of Kassel as "small" similarly to D. I. Fonvizin [Zinovyev: 349].

The motif of the German spatial miniatureness is interpreted otherwise in the sentimentalism travelogues. The expressions like "the small town" («маленькой городок») Heiligenbeil [Karamzin: 24], "two small towns" («два маленькие городка») Köslin and Körlin [Karamzin: 30], "small groves and villages" ("рощицы и деревеньки») [Karamzin: 61] etc. produce rather tenderness from N. M. Karamzin's narrator and mark the loci as idyllic.

A. T. Bolotov's representation of East Prussia balances between the idyllic and slightly ironic interpretations. The latter is actualized in the episode with the bishop of Ermland («бискуп эрмладдский») living like a "small appanage prince” («маленький удельный князь») [Bolotov 1: 641]. The motive 
of miniatureness is ironically stressed in A. T. Bolotov's description of the local life: «Жил он тут как маленький государь: имел у себя несколько военных людей <...; были у него также пушки и придворный маленький штат $<\ldots>$; но все сие в сущей миниатюре пред большими государями» ${ }^{1}$ [Bolotov 1: 641]. The author uses, however, diminutives with idyllic representing the small loci of East Prussia: "Prussian small towns" («прусские маленькие городки») [Bolotov 1: 639], "Prussian boroughs and towns” («прусские местечки и городки») [Bolotov 1: 640].

The motif of German spatial miniatureness in its idyllic form is travestied later, in I. P. Myatlev travelogue. Mme Kurdyukova declares in her critical manner against the Arcadian common places of sentimentalism: «Мне несносны деревушки, Пастухи, стада, пастушки» [Myatlev 1: 169]. The motif suffers a semantic 'erosion' in the Russian literature. But it keeps existing in a watered-down version. Exemplarily, N. A. Korsakov describes an idyllic "small German village" "with small white houses and $\langle\ldots\rangle$ tiled roofs” («немецкая деревушка; с белыми домиками и <...> черепичными крышами» [Korsakov: 13]).

Thus, a set of principal features that determines representation of the imaginal-geographic Germany in the Russian travelogues of the end $18^{\text {th }}-$ the first half of the $19^{\text {th }}$ centuries was stated. The main characteristic of the German literary space appears to be orderliness in two forms. The first one is based on the concept of rationality inspired by the Enlightenment. In this context, orderliness actualizes as civilization, spatial ordering and organizing, rational land management and comfort. The second form of the German order is connected with the Arcadian myth adopted by the sentimentalism discourse and also kept partly existing later, in the frames of other narratives - the romanticism discourse, the modalities of travesty and 'slice-oflife. The second form is connected with motives of peace, abundance, temperance, harmony relations between people and nature.

It must be stressed that these two forms do not exist separately but are often highly mixed. The anthropic-dimensional gentrifying space of Germany seems to be both idyllic and rationally organized in many cases. The images

${ }^{1}$ Cf. a non-ironic but idyllic image of similar German ruler's life in F. P. Lubyanovsky's travelogue: «Сам Князь [i.e. the Prince von Dessau] не что иное, как богатый помещик. Он скупил имение у всех дворян, и все Княжество есть его собственность. Сто инвалидов составляют всю его гвардию. $<\ldots>$ Он безвыездно живет в саду своем в Верлице и как частный владелец в спокойствии может иметь все удовольствия» [Lubyanovsky 1: 67]. 
of it are marked with the elements of Ratio and Emotio. German rulers' images contain features of an enlightened monarch but also of an idyllic patriarch.

Both the German idyll and the rationally organized loci are ambivalently marked in the Russian literature of the analyzed epoch. The idyll can be delighted and admired by the travelers but also ironically described as the territory of Philistines, narrow-minded bourgeois. Advances of civilization referring to the 'rational' Germany are appreciated, on the one hand. On the other hand, overorganizing the German space is determined as dangerous, slavish and oppressive in the context of human lives. The most illuminating example of it is the image of the German prison-city.

Along with orderliness, other stable features of the German loci in the Russian travelogues were determined like cleanness, accuracy, closeness, narrowness, miniatureness that is opposite to the Russian expanse. All of these features are connected someway or other with the concept of order and can be traced over the studied period of the Russian literature. 


\section{Список литературы \\ Источники}

Болотов А. Т. Жизнь и приключения Андрея Болотова: описанные самим им для своих потомков: в 4 т. СПб.: Печатня В. Головина, 1870-1973.

Гоголь Н. В. Полн. собр. соч.: в 17 т. М.: Изд-во Московской Патриархии, 20072010.

Горихвостов Д. П. Записки россиянина, путешествовавшего по Европе с 1824 по 1827 год: в 2 кн. М.: Тип. кн. Львова, 1831-1832.

Карамзин Н. М. Письма русского путешественника. Л.: Наука, 1984. 717 с.

Корсаков С. А. Рассказ о путешествии по Германии, Голландии, Англии и Франции Н. А. Корсакова в 1839 году. М.: Тип. Н. Эрнста, 1844.111 с.

Кюхельбекер В. К. Путешествие. Дневник. Статьи. Л.: Наука, 1979. 790 p.

Лубяновский Ф. П. Путешествие по Саксонии, Австрии и Италии в 1800, 1801 и 1802 годах: в 3 ч. СПб.: Медицинская тип., 1805.

Мятлев И. П. Сенсации и замечания госпожи Курдюковой за границею, дан п’этранже: в 2 т. СПб.: Изд-во А.С. Суворина, 1904.

Погодин М. П. Год в чужих краях (1839) в 4-х ч. М.: Университ. тип.; Тип. Н. Степанова, 1844.

Похождения прапорщика Климова: мемуары XVIII века. СПб.: Пушкинский Дом, 2017. 280 с.

Фонвизин Д. И. Собр. соч.: в 2 т. М.; Л.: Худож. лит., 1959.

Чччагов П. В. Записки. М.: Российский Архив, 2002. 800 с.

\section{Исследования}

Гачев Г. Д. Национальные образы мира. Эллада, Германия, Франция: опыт экзистенциальной культурологии. М.: Логос, 2008. 424 с.

Жданов С. С. Идиллический образ Германии в русском сентиментализме рубежа XVIII-XIX веков (на материалепроизведений Н. М. Карамзина и Ф. П. Лубяновского) // Сибирский филологический журнал. 2018. № 2. С. 53-66.

Зиноввев В. Н. Журнал путешествия по Германии, Италии, Франции и Англии (1784-1785) // Россия и Запад: горизонты взаимопознания. М.: ИМЛИ РАН, 2008. Вып. 3: Литературные источники последней трети XVIII века. С. 335-380.

Оболенская С. В. Германия и немцы глазами русских (XIX в.). М.: ИВИ РАН, 2000. $210 \mathrm{c}$.

Потапенко О. А. Николаевская Россия глазами немецкого путешественника: А. фон Гакстгаузен // Россия и Европа в XIX - XX веках. Проблемы взаимовосприятия народов, социумов, культур. М.: Ин-т истории РАН, 1996. С. 40-49.

Тирген П. Образы Аркадии в русской литературе XVIII-XIX вв. // Имагология и компаративистика. 2015. № 2 (4). С. 69-110.

Lebedeva O. B., Yanushkevich A. S. Deutschland im Spiegel der russischen Schriftkultur des 19. und beginnenden 20. Jahrhunderts. Cologne; Weimar, Vienna: Böhlau Verlag, 2000. $276 \mathrm{p}$. 
Leerssen J. Imagology: History and method // Imagology: The cultural construction and literary representation of national characters. A critical survey. Amsterdam; New York: Rodopi, 2007. P. 17-32.

Neumann B. Grundzüge einer kulturhistorischen Imagologie: Nationale Selbst- und Fremdbilder in britischer Literatur und anderen Medien des 18. Jahrhunderts // KulturPoetik. 2010. Bd. 10, H. 1. S. 1-24.

Neumann F. W. Deutschland im russischen Schrifttum // Die Welt der Slaven. 1960. H. 2. S. $113-130$.

Westphal B. Geocriticism. Real and Fictional Spaces. London: Palgrave Macmillan, 2011. $192 \mathrm{p}$. 


\section{References}

Gachev, G. D. Natsionalnye obrazy mira. Ellada, Germaniia. Frantsiia: opyt ekzistencialnoi kulturologii [National Images of the World. Hellas. Germany. France: Attempt of an Existential Culture Study]. Moscow, Logos Publ., 2008. 424 p. (In Russ.)

Zhdanov, S. S. "Idillicheskii obraz Germanii v russkom sentimentalizme rubezha XVIIIXIX vekov (na materiale proizvedenii N. M. Karamzina i F. P. Lubianovskogo)". ["Idyllic Image of Germany in Russian Sentimentalism at the Turn of the $19^{\text {th }}$ Century (Based on N. M. Karamzin's and F. P. Lubyanovskiy's Works)]. Sibirskii filologicheskii zhurnal, no. 2, 2018, pp. 53-66. (In Russ.)

Zinovyev, V. N. "Zhurnal puteshestviya po Germanii, Italii, Frantsii i Anglii (17841785)" ["Travelogues in Germany, Italy, France and England (1784-1785)"]. Rossiya i Zapad: gorizonty vzaimopoznaniya [Russia and the West: Horizons of Mutual Knowledge], vol. 3. Moscow, IWL RAS Publ., 2008, pp. 335-380. (In Russ.)

Obolenskaya, S. V. Germaniya i nemtsy glazami russkikh (XIX v.) [Germany and Germans as Seen by Russians (19 ${ }^{\text {th }}$ Century)]. Moscow, IWH RAS Publ., 2000. 210 p. (In Russ.)

Potapenko, O. A. "Nikolaievskaya Rossiia glazami nemetskogo puteshestvennika: A. von Haxthausen" ["Nicholas's Russia as Seen by a German Traveler: A. von Haxthausen"]. Rossiia i Evropa v XIX-XX vekakh. Problemy vzaimovospriiatiia narodov, sotsiumov, kultur [Russia and Europe in the $19^{\text {th }}-20^{\text {th }}$ Centuries. Issues of Mutual Perception of Nations, Societies, Cultures]. Moscow, IWH RAS Publ., 1996, pp. 40-49. (In Russ.)

Thiergen, P. "Obrazy Arkadii v russkoi literature XVIII-XIX vv." ["Images of Arcadia in Russian Literature of the $18^{\text {th }}-19^{\text {th }}$ Centuries]. Imagologiya $i$ komparativistika, no. 2 (4), 2015, pp. 69-110. (In Russ.)

Lebedeva, O. B., Yanushkevich, A. S. Deutschland im Spiegel der russischen Schriftkultur des 19. und beginnenden 20. Jahrhunderts. Cologne; Weimar, Vienna, Böhlau Verlag, 2000. 276 S. (In German)

Leerssen, Joep. Imagology: History and method. In: Imagology: The cultural construction and literary representation of national characters. A critical survey. Amsterdam; New York, Rodopi Publ., 2007, pp. 17-32. (In English)

Neumann, Birgit. Grundzüge einer kulturhistorischen Imagologie: Nationale Selbstund Fremdbilder in britischer Literatur und anderen Medien des 18. Jahrhunderts. KulturPoetik, 2010, Bd. 10, H. 1. S. 1-24. (In German)

Neumann, Friedrich. Wilhelm. Deutschland im russischen Schrifttum. Die Welt der Slaven. 1960, H. 2. S. 113-130. (In German)

Westphal, Bertrand. Geocriticism. Real and Fictional Spaces. London, Palgrave Macmillan Publ., 2011. 192 p. (In English) 


\title{
Образы природы в русской одической поэзии XVIII - начала XIX вв.: функциональные особенности и значение для литературного процесса
}

\begin{abstract}
Аннотация: Статья посвящена функциональным особенностям образов природы в формировании художественного мира русской одической поэзии XVIII - начала XIX вв. Рассмотрены примеры из одической поэзии М. В. Ломоносова, В. К. Тредиаковского, П. А. Сумарокова, М. М. Хераскова, Г. Р. Державина, Д. И. Хвостова. При этом делается попытка ответить на два вопроса: какое место образы природы занимали в одической поэзии в эпоху ее расцвета и можно ли, вопреки сложившемуся позднее в истории отечественной литературы снисходительному отношению к поэзии классицизма, найти в ней то, что составило органическую часть отечественной классики XIX и XX вв. Показана функциональная роль образов природы в одическом жанре, который, по определению, чужд природной тематике, будучи органически связан с пафосом гражданственности и обращением к темам героики, великих личностей, исторических событий. Однако в ряде случаев сами объекты природы вызывают восхищение поэта как впечатляюее создание Творца, в других ситуациях природа являет собою фон, который определенным образом оттеняет и усиливает остроту восприятия исторических событий, составляющих предмет одической поэзии. В статье делается вывод об определенной преемственности в изображении природы: от одической поэзии к отечественной лирике и прозе XIX и XX вв.
\end{abstract}

Ключевье слова: поэзия природы, ода, классицизм, М. В. Ломоносов, В. К. Тредиаковский, А. П. Сумароков, М. М. Херасков, Г. Р. Державин, Д. И. Хвостов.

Информация об авторе: Алексей Владимирович Святославский, доктор культурологии, доцент, профессор кафедры русской классической литературы, Институт филологии Московского педагогического государственного университета, ул. Малая Пироговская, д. 1, 119991 г. Москва, Россия.

ORCID ID: https://orcid.org/0000-0002-4909-8323

E-mail: platoacademia@yandex.ru

Дата поступления статьи в редакиию: 17.01 .2021

Дата одобрения статьи рецензентами: 22.03 .2021

Дата публикации статьи: 28.06.2021

Для иитирования: Святославский А. В. Образы природы в русской одической поэзии XVIII - начала XIX вв.: функциональные особенности и значение для дальнейшего литературного процесса // Два века русской классики. 2021. Т. 3, № 2. C. 40-61. https://doi.org/10.22455/2686-7494-2021-3-2-40-61 


\title{
A. В. Святославский. Образы природы в русской одической поэзии XVIII - начала XIX вв.
}

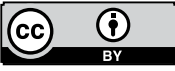

This is an open access article distributed under the Creative Commons Attribution 4.0 International (CC BY 4.0)
Dva veka russkoi klassiki, vol. 3 , no. 21,2021 , pp. 40-61. ISSN 2686-7494

Two centuries of the Russian classics, vol. 3, no. 2, 2021, pp. 40-61. ISSN 2686-7494

Research Article

(C) 2021. Alexey V. Svyatoslavsky Moscow State Pedagogical University Moscow, Russia

\section{Nature Images in Russian Odic Poetry of the $18^{\text {th }}-$ Early $19^{\text {th }}$ Centuries: Functional Role and Influence on the Further Literary Process}

\begin{abstract}
The article is devoted to the functional role of nature images in the formation of the imaginary structure of Russian odic poetry of the $18^{\text {th }}-$ early $19^{\text {th }}$ centuries. Examples are taken from the odic poetry of Mikhail Lomonosov, Vasily Trediakovsky, Alexander Sumarokov, Mikhail Kheraskov, Gavrila Derzhavin, Dmitry Khvostov. An attempt was undertaken to answer two questions: the place nature images occupied in odic poetry in the era of its pride and, secondly, the possibility to find in the poetry of classicism, despite the condescending attitude towards it that developed later in the history of Russian literature, something that constituted an organic part of the Russian classics of the $19^{\text {th }}$ and $20^{\text {th }}$ centuries. The functional role of nature images in the odic genre is shown, which, as it seemed, by definition is alien to natural themes, being organically connected with the pathos of civic consciousness and the appeal to the themes of heroism, great personalities, and historical events. However, as it turns out in a number of cases, the very objects of nature evoke the poet's admiration as an impressive work of the Creator, in others, nature is a background that in a certain way enhances the impression of the very historical events that constitute the subject of odic poetry. The conclusion is made about a certain continuity in the depiction of nature - from odic poetry to Russian lyric poetry and prose of the $19^{\text {th }}$ and $20^{\text {th }}$ centuries.
\end{abstract}

Keywords: Poetry of nature, ode, classicism, Michael Lomonosov, Vasily Trediakovsky, Alexander Sumarokov, Michael Kheraskov, Gabriel Derzhavin, Dmitry Khvostov.

Information about the author: Alexey V. Svyatoslavsky, DSc in Cultural Research, Professor, Moscow State Pedagogical University, Malaya Pirogovskaya St., 1, 119991

Moscow, Russia. ORCID ID: https://orcid.org/0000-0002-4909-8323

E-mail: platoacademia@yandex.ru

Received: January 23, 2021

Approved after reviewing: March 16, 2021

Published: June 28, 2021

For citation: Svyatoslavsky, A. V. "Nature Images in Russian Odic Poetry of the $18^{\text {th }}-$ Early $19^{\text {th }}$ Centuries: Functional Role and Influence on the Further Literary Process."

Dva veka russkoi klassiki, vol. 3, no. 2, 2021, pp. 40-61. (In Russ.)

https://doi.org/10.22455/2686-7494-2021-3-2-40-61 
С наступлением «золотого века» русской литературы образы природы прочно заняли свое место в эпической прозе и в лирике как неотъемлемый компонент отражения мировосприятия автора. С юных лет читатели знакомятся с замечательными зарисовками родной земли в лирике А. С. Пушкина, в его романе «Евгений Онегин», сюжет, проблематика и коллизии которого, казалось бы, никак напрямую не связаны с темой природы. Но «Евгений Онегин» создавался уже тогда, когда литературные каноны, привычки, традиции XVIII в. уходили все дальше. В целом и для самого А. С. Пушкина характерно отчасти скептическое отношение к прошедшей эпохе: наряду с признательностью к Г. Р. Державину, Пушкин скептически настроен по отношению к творчеству А. П. Сумарокова, видит в нем немало архаичного, известно также его ироническое отношение к Дмитрию Хвостову как к графоману, одержимому манией публичного чтения своих стихов. Пушкин даже написал «Оду его сиятельству графу Хвостову», где пародировал выспренный стиль автора. Анализируя указанное произведение, Ю. Н. Тынянов пришел к выводу, что оно явилось «полемическим ответом воскресителям оды, причем пародия на старинных одописцев явилась лишь рамкою для полемической пародии на современного воскресителя старой оды Кюхельбекера и на защитника новой оды Рылеева» [Тынянов 1968: 115]. В ранней лирике Пушкина не могло не ощущаться влияние поэзии предшествующей эпохи, более того, поэт и позднее обращался к торжественному одическому стилю, когда считал это оправданным, как например, в адресованном Н. Б. Юсупову послании «К вельможе», написанном в 1830 г. Очевидно, что эволюция русского стихосложения к началу XIX в. была закономерной, органически вырастала из того, что было сделано предшественниками, а Пушкину суждено было открыть путь к полной реализации возможностей русского языка в поэзии.

Пушкинское мнение о Сумарокове известно, в частности, из послания «К Жуковскому» (1816): 
Но кто другой, в дыму безумного куренья, Стоит среди толпы друзей непросвещенья? Торжественной хвалы к нему несется шум: Он, он под рифмою попрал и вкус и ум; Ты ль это, слабое дитя чужих уроков, Завистливый гордец, холодный Сумароков, Без силы, без огня, с посредственным умом, Предрассуждениям обязанный венцом И с Пинда сброшенный и проклятый Расином?

Ему ли, карлику, тягаться с исполином? Ему ль оспоривать тот лавровый венец, В котором возблистал бессмертный наш певец, Веселье россиян, полунощное диво?.. [Пушкин 1936. 1: 160].

Здесь Сумароков противопоставлен М. В. Ломоносову, по-видимому, в аспекте известной литературной дискуссии о правилах стихотворства, столкнувшей В. К. Тредиаковского, М. В. Ломоносова и А. П. Сумарокова в 1740-х гг. Под «исполином» имеется в виду Ломоносов, хотя известно, что и о нем Пушкин оставил не только восторженные строки как об ученом («сам был первым университетом»), но также достаточно прохладный отзыв как о поэте. О поэтах XVIII в. Пушкин размышляет, в частности, в статье «Путешествие из Москвы в Петербург» (1833-1834), где пишет: «В Ломоносове нет ни чувства, ни воображения. Оды его, писанные по образцу тогдашних немецких стихотворцев, давно уже забытых в самой Германии, утомительны и надуты <...>. Высокопарность, изысканность, отвращение от простоты и точности, отсутствие всякой народности и оригинальности - вот следы, оставленные Ломоносовым» [Пушкин 1936. 5: 362]. Общий же вывод Пушкина в рассуждении о поэтах ушедшего века сделан в пользу В. К. Тредиаковского, в котором Пушкину нравится «обширнейшее» понятие о русском стихосложении, отсутствующее у Ломоносова, Сумарокова и Хераскова: «Вообще изучение Тредиаковского приносит более пользы, нежели изучение прочих наших старых писателей, Сумароков и Херасков верно не стоят Тредиаковского» [Пушкин 1936. 5: 366]. Тем не менее заметим, что обоснованная Ломоносовым возможность введения в современную русскую поэзию элементов церковнославянского языка - как особый стилистиче- 
ский прием - вполне использованы самим Пушкиным, например, в стихотворении «Пророк».

На первый взгляд жанр высокой одической поэзии, характерной для XVIII в., должен содержать как объект славословия историю и образы героических личностей, знаменательные события, будить гражданские чувства, но никак не описывать природу. Однако аналитическое изучение поэтических текстов показывает обратное.

Функциональное многообразие образов природы в русской поэзии проявило себя уже в творчестве одописцев допушкинской эпохи, оказавших серьезное влияние на развитие пейзажной лирики XIX в. В данной статье мы постараемся показать, какое место образы природы занимали в одической поэзии в эпоху ее расцвета; проанализируем характер восприятия и осмысления самого феномена природного мира у мастеров русской оды: Тредиаковского, Ломоносова, Сумарокова, Хераскова, Державина, Хвостова.

В 1726 (27?) г. В. К. Тредиаковский пишет стихотворение «Описание грозы, бывшия в Гаге», не называя его одой, но исполнив целиком в стилистической традиции одической поэзии. В этом случае объектом описания стало само по себе явление природы, но не рядовое, а страшное и величественное, что отвечает в принципе высокому торжественному настрою этого рода поэзии:
С одной страны гром,
С другой страны гром,
Смутно в воздухе!
Ужасно в ухе!
Набегли тучи
Воду несучи
Небо закрыли,
В страх помутили!.. [Тредиаковский 1963: 95].

В последних строфах этого стихотворения автор вводит и прямое обращение к силам природы, стихиям («О солнце красно! Стань опять ясно...; А вы, аквилоны, будьте как и оны...»). Позднее, в 1735 г., Тредиаковский создает уже собственно оду, адресованную природе: «Ода в похвалу цвету розе», где обращается к форме прямого диалога с цветком как объектом одического послания. Тредиаковский в этом 
произведении заявляет себя также новатором стиля, предпослав тексту специальное примечание: «Сочинена нарочно новым российским пентаметром для примера».

Красота весны! Роза о прекрасна!

Всей, о госпожа, румяности власна!

Тя во всех садах яхонт несравненный,

Тя из всех цветов цвет предрагоценный,

О цветов тя всех славную царицу,

Само цветников солнце, не зарницу!

Похвалить теперь я хотя и тщуся,

Но багряну зря и хвалить стыжуся.

Как природа в свет тя производила,

Лучшему в тебе быть определила... [Тредиаковский 1963: 403].

У Ломоносова обращение к природе носит более «утилитарный» характер. Оба известных ломоносовских «Размышления о Божием величестве», хотя и включают картины природы, но, во-первых, в них важно не столько проникновение в красоту природы, сколько славословие Творца и, во-вторых, проявлен интерес ученого к физическим процессам. В 1753 г. в пояснениях к «Слову о явлениях, от электрической силы происходящих», Ломоносов сообщал: «Ода моя о северном сиянии, которая сочинена 1743 года, а в 1747 году напечатана, содержит мое давнишнее мнение, что северное сияние движением эфира произведено быть может» [Ломоносов 1952: 123].

Действительно, полностью стихотворение называется «Вечернее размышление о Божием величестве при случае великаго северного сияния»:

Лице свое скрывает день:

Поля покрыла мрачна ночь;

Взошла на горы чорна тень;

Лучи от нас склонились прочь;

Открылась бездна, звезд полна;

Звездам числа нет, бездне дна.

$<\ldots>$ 
Для общей славы Божества

Там равна сила естества.

Но где ж, натура, твой закон?

С полночных стран встает заря!

Не солнце ль ставит там свой трон?

Не льдисты ль мещут огнь моря?

Се хладный пламень нас покрыл!

Се в ночь на землю день вступил!

О вы, которых быстрый зрак

Пронзает в книгу вечных прав,

Которым малый вещи знак

Являет естества устав,

Вы знаете пути планет;

Скажите, что наш ум мятет?

Что зыблет ясный ночью луч?

Что тонкий пламень в твердь разит?

Как молния без грозных туч

Стремится от земли в зенит?

Как может быть, чтоб мерзлый пар

Среди зимы рождал пожар?.. [Ломоносов 1959: 120-121].

При небольшом внимании современных читателей к поэзии Ломоносова, позволим заметить, что первые шесть строк приведенного стихотворения широко известны по школьным хрестоматиям и являют собой образец поэзии XVIII в., не потерявший эстетической значимости для широкого читателя до сих пор. Согласно справедливому мнению П. Е. Бухаркина, эта духовная ода «бесспорно принадлежит к самым совершенным сочинениям "Российского Пиндара", в ней полностью проявился его поэтический гений» [Бухаркин 2006: 39]. В целом же Ломоносов достаточно строго придерживается одического канона в выборе поэтического объекта, адресуясь обычно к членам императорской фамилии по случаям коронаций, тезоименитств, бракосочетаний и т. п.

Интересно мнение М. Л. Гаспарова, заметившего, что «духовные оды тоже были разные, и у Ломоносова держались на пафосе, а у Сумарокова на вразумлении» [Гаспаров 2003: 239]. Сумароков значительно расширяет возможности одического жанра, соединяя его также с духом 
анакреонтической поэзии. Адресатами такой поэзии становятся и возлюбленные, и друзья, и, что важно для нашей темы, природа, понимаемая достаточно широко. Сумароков пишет «Гимн о премудрости Божией в солнце» (1760), в котором адресатом выступает главное светило:

Светило гордое, всего питатель мира, Блистающее к нам с небесной высоты! О, если бы взыграть могла моя мне лира Твои достойно красоты! <...>

О солнце, ты - живот и красота природы, Источник вечности и образ божества! Тобой жива земля, жив воздух, живы воды, Душа времен и вещества! <..>

Тобою всякое дыханье ликовствует, Встречает радостно лицо твое вся тварь, Пришествие твое вседневно торжествует; Небесных тел ты - вождь и царь!

Объемля взором всю пространную державу,

Вовеки бодро бдя, не дремля николи, Великолепствуя, вещаешь Божью славу, Хваля творца по всей земли [Сумароков 1957: 87-88].

В стихотворении 1760 г. без специального названия, озаглавленном просто «Ода», Сумароков обращается к реке Волге:

Долины, Волга, потопляя,

Себя в стремлении влечешь, Брега различны окропляя, Поспешно к устию течешь.

Ток видит твой в пути премены, Противности и блага цепь; Проходишь ты луга зелены, Проходишь и песчану степь. 
Век видит наш тому подобно

Различные в пути следы:

То время к радости способно,

Другое нам дает беды.

В Каспийские валы впадаешь,

Преславна мати многих рек,

И тамо в море пропадаешь,

Во вечности и наш так век [Сумароков 1957: 102].

Стихотворение строится на основе аналогии: река, впадающая в бесконечность моря, возбуждает мысль о веке, впадающем в бесконечность времени. По сути дела, перед нами предвестье знаменитой русской философской лирики XIX-XX вв., указанный прием ощутим, например, в стихотворении Ф. И. Тютчева: «Дума за думой, Волна за волной...» (1851).

Обратимся далее к поэзии М. М. Хераскова, в которой Н. И. Либан находил сильное лирическое начало: «Херасков был писатель лирический, и хотя написал много од, в них постоянно звучит приглушенная лирическая нота... Для Хераскова Ломоносов уже был прошедшим. Херасков - лирический поэт, глубокий поэт, овладевший новым стихом» [Либан 2014: 234-235]. В стихотворении «Комета, явившаяся в 1767 году при начале войны с турками» Херасков вслед за Ломоносовым обращается к величественной панораме неба. Строка «Открылась смесь несчестных звезд» интертекстуально оказывается связана с ломоносовской строкой «Открылась бездна звезд полна»:

Великое число светил

Творец вселенныя вместил

Безмерной высоты в пространстве:

Когда возводим очеса

При лунном свете в небеса,

Мы видим их в златом убранстве.

В широком поле горних мест

Открылась смесь несчетных звезд;

Погружены в пучине вечной,

Иные видимы в ночи, 
Как будто солнечны лучи,

Рекой другие зрятся млечной... [Херасков 1961: 134].

Однако смысл произведения не сводится к любованию и восхищению природой, оно служит прелюдией к размышлению о комете, которая видится автору мечом Божиим, готовым обрушиться на врагов России, иноверцев:

Не мир подвигся Бог зажечь, Но, огненный иссунув меч, Ко грешникам речет в комете: «Я мрачны ваши зрю сердца; О тварь! не раздражай творца, Коль хочешь жить еще на свете»... [Херасков 1961: 135].

Примером природной лирики у Хераскова может быть стихотворение 1783 г. «Апрель»:

Дыханьем нежным побежденны,

Седые мразы прочь летят;

От плена их освобожденны, Потоки вод в брегах шумят. Полям и рощам обрученна, Восходит на горы весна, Зеленой ризой облеченна, Умильный кажет взор она.

Уготовляя царство лету, Приближилося солнце к нам, Прибавило дневного свету И жизни хладным сим странам... [Херасков 1961: 136].

Лирический герой стихотворения долго любуется пробуждающейся природой, но затем вдруг приходит к несколько даже неожиданной моралистической концовке:

$<. . .>$ только мы забыли,

Чем прежних жизнь людей сладка; 
Увы! они невинны были;

Невинность в наши дни редка.

Друг другу мы напоминаем

Желаний наших главну цель;

Апрель обманом начинаем,

Едва ль не весь наш век - апрель [Херасков 1961: 137].

Интересным примером одической поэзии на тему природы является хорошо известная ода Державина «Водопад», над которой автор работал несколько лет, начиная с 1891 г. Считается, что Державин описывает водопад Кивач на реке Суне в Карелии. Начало оды рисует величественную картину этого явления природы:

\author{
Алмазна сыплется гора \\ С высот четыремя скалами, \\ Жемчугу бездна и сребра \\ Кипит внизу, бьет вверх буграми; \\ От брызгов синий холм стоит, \\ Далече рев в лесу гремит. \\ Шумит, и средь густого бора \\ Теряется в глуши потом; \\ Луч чрез поток сверкает скоро; \\ Под зыбким сводом древ, как сном \\ Покрыты, волны тихо льются, \\ Рекою млечною влекутся... [Державин 1817: 180].
}

Однако далее, следуя традиции одической поэзии, Державин переходит к размышлениям о великих делах российских героев, прославленных в завоевании южнорусских земель: Г. А. Потемкина, П. А. Румянцева-Задунайского. Ода полна иносказаний и допускает различные толкования. Чаще всего в самом образе водопада ищут отражение натуры и деяний прямо и перифрастически упоминаемого в тексте Потемкина (в собрании сочинений Державина, выходившем с 1864 по 1883 гг. с примечаниями Я. Грота, ода в оглавлении прямо обозначена с подзаголовком «Памяти Потемкина») - в образе старца, созерцающего водопад как образ жизни человеческой: 
Я вижу - некий муж седой

Склонился на руку главой.

Копье и меч, и щит великой,

Стена отечества всего,

И шлем, обвитый повиликой,

Лежат во мху у ног его.

В броне блистая златордяной,

Как вечер во заре румяной,

Сидит - и, взор вперя к водам,

В глубокой думе рассуждает:

«Не жизнь ли человеков нам

Сей водопад изображает?

Он так же блеском струй своих

Поит надменных, кротких, злых.

Не так ли с неба время льется,

Кипит стремление страстей,

Честь блещет, слава раздается,

Мелькает счастье наших дней,

Которых красоту и радость

Мрачат печали, скорби, старость? [Державин 1817: 181-182].

В 1822 г. Н. Ф. Остолопов, знавший Державина по совместной работе в журнале «Любитель словесности», опубликовал «Ключ к сочинениям Державина с кратким описанием жизни сего знаменитого поэта» [Остолопов, 1822] — научный комментарий, который создавался как новый и необходимый русской литературе жанр. В нем Остолопов расшифровывает для читателей-потомков символический и образный строй «Водопада», пользуясь комментариями самого Державина. Уже тогда было очевидно, что без подобного комментария полноценное восприятие стихотворения в принципе невозможно.

Ода «Водопад» еще в большей мере, чем «Апрель» Хераскова, может быть отнесена к философской лирике. В «Литературных мечтаниях» (1834) В. Г. Белинский отметил эстетический заряд державинской оды: «Какой энергическою и дикою красотою дышит его (Державина. - A. C.) “Водопад”: Это песнь угрюмого севера, пропетая сребровласым скальдом во глубине священного леса, среди мрачной ночи, у пылающего дуба, зажженного молниею, при оглушаю- 
щем реве водопада» [Белинский 1948. 1: 36]. Однако позднее, в статье 1843 г. «Сочинения Державина», подвергнув оду подробному анализу, Белинский приходит к выводу о том, что бесконечные рассуждения и философствования автора скрадывают главное - картину природы. Рациональное убивает поэтическое. Белинский считает, что «все эти 186 стихов можно выкинуть, и ода ничего не проиграет, напротив, многого выиграет: в ней будет меньше риторики и больше поэзии» [Белинский 1948. 2: 493].

Поэзия графа Дм. И. Хвостова во многом была наполнена приемами уходящего XVIII в., однако при этом поэт оказался современником Пушкина (скончался Хвостов в 1835 г.). И. Ю. Виницкий, рассуждая о литературной борьбе И. И. Дмитриева и Д. И. Хвостова за литературную репутацию «истинного поэта», пишет: «Дмитриев победил. Однако литературное поражение Хвостова не привело к его забвению. Напротив, <..> оно привело к рождению нового культурного персонажа в русской поэзии - создателя нелепого, но по-своему эстетического мира» [Виницкий 2016: 183]. Так Хвостов воспринимался и в пушкинское время, своеобразное положение его в русской поэзии вызвало определенный интерес к нему у современных исследователей.

Рассмотрим достаточно знаковую для творчества Хвостова оду «Реке Кубре» (1806) (как и у Сумарокова, эта ода обращена к реке). В отличие от сумароковской оды Волге, не величие главной российской реки и не аналогии с историческим временем волнуют автора, а ностальгия по местам, где находилось родовое имение Хвостовых - Выползова Слободка - и где прошли частью юные, частью зрелые годы графа Хвостова. Ода Хвостова носит куда более интимный лирический характер. Если для Сумарокова образ Волги - это повод для философских размышлений, то для Хвостова река - символ малой родины, некий знак в его личной знаковой системе, вобравший в себя и усадьбу, и окрестные поля, и всю атмосферу маленького уголка Залесского ополья. Волга - главная река России, она принадлежит всем, она символ всей России. Кубра (тж. Кубря, Кубрь) - речка маленькая, мало кому известная и сегодня, протекающая, петляя у границ московских, ярославских и владимирских земель.

И. Ю. Виницкий подметил, что «в своем творчестве Дмитрий Иванович стремился сделать Слободку соперницей державинской Зван- 
ки... (с Гаврилой Романовичем Дмитрий Иванович упорно, но, увы, безуспешно состязался)» [Виницкий, 2016: 55]. Кубра «вспоила» автора, дала ему все то хорошее, что в нем есть, и поэтому ода начинается с благодарения:

Кубра! Ты первая поила

Меня Пермесскою водой;

Ты душу юну возбудила

Прельщаться Греков простотой.

Я на твоем брегу высоком

Всегда спокойным сердцем, оком

Ловил природы красоты;

Не знал кумиров зла, ни мести,

Не зрел рабов коварства, лести,

И собирать хотел цветы [Хвостов 1828: 167].

Очевидно, что уже здесь прослеживается столь важная для всей русской литературы XIX и XX вв. роль природы как источника поэтического вдохновения, далее ощутимая в творчестве А. С. Пушкина, М. Ю. Лермонтова, Н. А. Некрасова, А. А. Фета, Б. Л. Пастернака. Аллюзия, связанная с перенесением образа вод Пермесса, поивших муз, на Кубру - не просто столь любимый в классицизме «реверанс» античности, но выражение благодарности уголку родины, впервые возбудившему поэтическое вдохновение в авторе.

Попробуем выяснить, что еще дает одическая форма Хвостову, который, казалось бы, должен был распрощаться с этим жанром, совершая поворот от размышлений о высоких гражданских и космических материях к миру своей души. Отметим диалогичность - особенность одической поэзии, которая сохранит себя и далее, проявляясь в беседе авторов и лирических героев с миром природы. В литератуpe XX в. диалог с природой получит особенное развитие в творчестве М. М. Пришвина, все творчество которого выросло из записных книжек, наполненных диалогами с природой. Кстати, хвостовская и пришвинская творческие биографии пересеклись на Кубре. Случилось так, что именно Пришвин оказался тем писателем, который воспел Кубрь вслед за Хвостовым, совершив в 1925 г. водное путешествие по Нерли и Кубре: «Кубря - прозрачная, глубоководная, со своими ви- 
димыми с берега чудесными подводными лесами, со своими широкими заводями - прекрасна, такой прекрасной реки я в жизни своей не видал $<\ldots>$ Я переполнен счастьем, мне хочется открыть всем глаза на возможности для человека жить прекрасно, дышать таким солнечно-морозным воздухом, смотреть и слушать лилии, угадывать их музыку <...>. Эти лилии мне говорят теперь, что творчество есть расширение Настоящего до Будущего: настоящее становится так широко, что захватывает в себя и все будущее» [Пришвин 1983: 53].

В оде «Реке Кубре» как один из основных композиционных приемов используется антитеза Кубра - Нева. Само по себе это примечательно не только потому, что Нева - река столичная и стяжавшая в отечественной классицистической поэзии дифирамбов едва ли не больше всех остальных рек, но потому, что, как замечает А. Е. Махов, «Хвостов географически двойственный поэт. Жизнь его делилась между Петербургом и Переславлем с его Выползовой слободкой, между Невой и Куброй... Он гордился, что был певцом двух рек» [Махов 1999: 15]. При обращении к образу Петербурга (третья строфа) используется прием перифразы:

\author{
Я от струи твоей прозрачной \\ Приятных и спокойных вод \\ В предел я поселился мрачный, \\ В превратный пояс непогод... [Хвостов 1828: 168].
}

Причем «предел мрачный», как явствует из дальнейшего текста, относится не только к нездоровому климату Петербурга, но к обстановке петербургской жизни. Прослеживается параллелизм: природное соответствует социальному и духовному.

В первом четырехтомном издании сочинений Хвостова 1817 г. строчка «Где светлый жезл куют морозы» (метафорический образ сосульки) была представлена как «Где светлу цепь куют морозы» [Хвостов 1817: 47]. На наш взгляд, и в плане образном, и в композиционном второй вариант стиха удачнее: «Жезл» нам кажется куда выразительнее и уместнее, к тому же размер тогда не требует столь утомляющей своим изобилием у классицистов усеченной формы прилагательного «светлу» вместо «светлый». Впрочем, сама по себе эта вторая строфа в варианте первого издания Полного собрания 
стихотворений графа Хвостова (1817-1818) местами может показаться более изящной, это дело вкуса. Ниже в левой колонке приводим вариант первого, четырехтомного издания Собрания стихотворений [Хвостов 1817: 47], а в правой колонке - вариант строфы из третьего, восьмитомного издания [Хвостов 1828: 168], воспроизведенного уже в наше время в «Библиотеке поэта» [Поэты 1971: 435-437]:

1817

Я от струи твоей прозрачной Приятных и спокойных вод В предел переселился мрачной, В превратно царство непогод, Где светлу цепь куют морозы, Где век дышать не могут розы И где владетель злой - Борей Крыле шумящи простирает, Далече волны посылает, Губит богатый злак полей.
1828

Кубры оставя ток прозрачный Приятных и спокойных вод, В предел я поселился мрачный, В превратный пояс непогод, Где светлый жезл куют морозы, Весной дышать не могут розы, И где сердитый царь Борей, Неистовым свирепством полный, Далече посылает волны Губить богатый злак полей.

Четвертая строфа содержит весьма уместную в данном контексте метафору «ложе реки»: с ложа начинается и на ложе завершается жизнь человека, но река течет непрерывно и переводит смысл в образ вечного движения жизни. Кубра выступает как Родина-мать: родство с местом подчеркивается упоминаниями о могилах матери и отца на малой родине: «Где те, что мне всего дороже...» [Хвостов 1828: 169]. Эта строчка снабжена примечанием самого автора, говорящего о себе в третьем лице: «Сей стих, относящийся к пребыванию в селе Слободке почтенных родителей автора, где при церкви по смерти покоится их прах, неоднократно был повторяем в его стихах. См. Дамский журнал 1827 года № 14, где между прочим, при разборе пятого тома нашего автора, сказано о сем стихе: “Священный памятник бытия его - прах родительский”» [Хвостов 1828: 300].

Приведем эту строфу в варианте первого издания (левая колонка) [Хвостов 1817: 49] и третьего издания (правая колонка) [Хвостов 1828: 169]: 


\section{7}

Кубра, виясь кольцом и ныне, Спешит мои березки мыть, Течет торжественно в долине. Зачем не суждено век жить Мне там, Кубра, твое где ложе, Где те, что мне всего дороже, Где я без желчи воду пил, В восторге радостном и мире Играл среди весны на лире, И сладость бытия вкусил.
1828

Твои струи кольцом и ныне Спешат мои березки мыть, Текут в приятнейшей долине. Зачем не суждено век жить Мне там, Кубра! твое где ложе, Где те, что мне всего дороже Где я без желчи воду пил? В восторгах радости и мире Весенни дни играл на лире И сладость бытия вкусил.

С печалью поверяет лирический герой Хвостова своей родной реке, что променял он ее берега, где прежде «без желчи воду пил», на берега Невы и мрачный мир Петербурга. Метафора вызывает в сознании читателя представление о желчной атмосфере петербургского света, атмосфере вечных насмешек в адрес Хвостова от собратьев по перу, не желающих понять особенностей его художественного видения мира. «Неправ был Д. В. Дашков, - пишет А. Е. Махов, - когда в своей издевательской речи при приеме Хвостова в Общество любителей словесности, наук и художеств в 1812 г., помянув “зубастых голубей”, заявил, что Хвостов “творит новый мир, новую природу” - Хвостов не творил новую природу, но приводил в порядок имеющуюся» [Махов 1999: 12].

Последняя строфа «Оды к реке Кубре» исполнена изящно с точки зрения риторической диспозиции. Используется фигура аналогии: течение жизни автора уподоблено течению реки. Эта строфа венчает сам текст, подводя итог и жизни Хвостова, и его отношениям с малой родиной. Перед нами снова обращение, адресованное непосредственно к Кубре, а последняя строка, наиболее значимая, содержит завещание поэта:

Пускай Кубры прозрачной воды

Мне в сердце радости вольют;

И лет моих преклонны годы

Без огорчений потекут.

Она мила между реками, Приятно щедрыми судьбами 
я совершаю срок годов.

Я начал здесь играть на лире,

Засну, оконча песнь Темире,

При шуме от ея валов [Хвостов 1828: 171].

В редакции собрания сочинений 1817 г. эта строфа звучала иначе:

Пускай твои спокойны воды

Мне в сердце радости прольют;

Пускай мои оставши годы

Тебе подобно потекут!

Как ты в реках мила, незнатна,

Так ныне жизнь моя приятна

Склоняет к западу свой путь.

Здесь начал я играть на лире,

Здесь кончу поздну песнь Темире,

Здесь должен мирно я уснуть [Хвостов 1817: 50].

Проанализированные примеры позволяют говорить о целом ряде намеченных в XVIII столетии функциональных особенностей образов природы. Это параллелизм, аналогии, когда созерцание картин природы становится импульсом к размышлению о человеке, о социально-психологических явлениях, синестетически, метафорически связанных с явлениями природы в сознании поэта. Это любование природой как творением Бога, которому по определению присуща внутренняя гармония. Это природа как фон, на котором призваны разворачиваться исторические события. И наконец, у Хвостова природа как источник ностальгии, как объяснение в любви с Родиной. У Хвостова, творившего уже в XIX в., при всем несовершенстве художественной формы, образы природы становятся все более значимыми и самоценными, они призваны возбуждать не только мысль, но и чувства.

Природная тематика, как мы убедились, переплетена с размышлениями о философских вопросах, о вечности, о душе, и, конечно, о жизни и смерти. «Уже к середине XVIII века смерть сделалась одной из ведущих литературных тем», - заметил Ю. М. Лотман [Лотман 1994: 212-213], анализируя русскую культуру той эпохи. И все это, природ- 
ное и духовное, объединяется образом Творца, тем самым как бы восстанавливает всеобщую гармонию мира через поэзию.

Подытоживая краткий анализ функциональных особенностей образов природы в одической поэзии XVIII - начала XIX вв., сделаем следующие выводы. Удивление перед природой как Божьим творением, особенно в величественных картинах грозы, водопада, в нерукотворной красоте, отражает религиозный характер сознания, проявляющийся в восхищении, в ощущении величия Бога, явленного в силах природы. Так, в приведенных выше строках Тредиаковского грозовые тучи, закрывшие небо, способны «помутить» человека в страх. Сумароков, принося благодарение Творцу за дарованное людям светило, при этом в самом солнце видит «образ божества».

Созерцание величественных явлений, как у Ломоносова перед картиной звездного неба, рождает эстетическое наслаждение и в то же время обращает мысль к бесконечности Вселенной, как это происходит в «Комете» Хераскова. У Хераскова к тому же проявляется ощущение мистической связи явлений природы с миром человеческих дел, когда комета осмысляется как знак неблаговоления Божьего к врагам России. От величия водопада к величию деяний российских героев на поле брани органично перетекает мысль Державина.

Поэзия XVIII в. так или иначе демонстрирует ассоциативную связь мира природы и мира человека, параллелизм и определенную взаимосвязь явлений материальной и духовной жизни. В этом отношении она наследует фольклору и в то же время готовит почву для философской лирики XIX в. Природа вдохновляет поэтов на философские размышления о человеке и мире, когда бесконечное движение воды становится метафорой течения лет, течения жизни человеческой. Но дело не только в явлениях, призванных потрясать воображение: гармония природы вызывает у поэтов желание просто любоваться красотой, делясь этим чувством с читателем, как это происходит в «Оде в похвалу цветку розе» у Тредиаковского, в стихотворении «Апрель» Хераскова. У Хераскова, впрочем, такое любование пробуждающейся весенней природой в заключительной части стихотворения наводит на мораль: весна жизни человеческой хороша, но не вечна. У Хвостова образ реки обретает более сложный характер символа Родины, органичной гармонии сельской жизни, противопоставленной урбанизированной столице. В то же время он выражает и ностальгию по прошлому. Образ 
родной природы, возбуждающей воспоминания о детстве, юности, о корнях, получит дальнейшее развитие в литературе XIX в.

\section{Источники}

Державин Г. Р. Лира Державина или Избранные его стихотворения. М.: Университ. тип., 1817. 385 с.

Ломоносов М. В. Вечернее размышление о Божием величестве при случае великого северного сияния // Ломоносов М. В. Полн. собр. соч.: в 11 т. М.; Л.: Изд-во АН СССР, 1959. Т. 8: Поэзия. Ораторская проза. Надписи. С. 120-123.

Ломоносов М. B. Orationis de meteoris electrices explanationes. Изъяснения, надлежащие к слову о электрических воздушных явлениях // Ломоносов М. В. Полн. собр. соч.: в 11 т. М.; Л.: Изд-во АН СССР, 1952. Т. 3. С. 101-134.

Поэты 1790-1810-х гг. / вступ. ст. и сост. Ю. М. Лотман. подгот. текста М. Г. Альтшуллер. Л.: Сов. писатель, 1971. 912 с.

Пришвин М. М. Собр. соч.: в 8 т. Т. 5. М.: Худож. лит., 1983. 439 с.

Пушкин А. С. К Жуковскому // Пушкин А. С. Полн. собр. соч.: в 6 т. / под ред. М. А. Цявловского. М.; Л.: Academia, 1936. Т. 1. С. 159-162.

Пушкин А. С. Путешествие из Москвы в Петербург // Пушкин А. С. Полн. собр. соч.: в 6 т. / под ред. М. А. Цявловского. М.; Л.: Academia, 1936. Т. 5. С. 356-378.

Сумароков А. П. Долины, Волга, потопляя // Сумароков А. П. Избранные произведения. Л.: Сов. писатель, 1957. С. 87-88.

Сумароков А. П. Гимн о премудрости Божией в солнце // Сумароков А. П. Избранные произведения. Л.: Сов. писатель, 1957. С. 87-88

Тредиаковский В. К. Ода в похвалу цвету розе // Тредиаковский В. К. Избранные произведения. М.; Л.: Сов. писатель, 1963. С. 403-404.

Тредиаковский В. К. Описание грозы, бывшия в Гаге // Тредиаковский В. К. Избранные произведения. М.; Л.: Сов. писатель, 1963. С. 95-96.

Хвостов Д. И. Сочинения / сост. О. Л. Довгий, А. Е. Махов. М.: INTRADA, 1999. $224 \mathrm{c}$.

Хвостов Д. И. Реке Кубре // Полное собрание стихотворений графа Хвостова: в 4-х ч. СПб.: В тип. Императорскаго Воспитательнаго дома, 1817. Ч. 1. С. 46-50.

Хвостов Д. И. Реке Кубре // Полное собрание стихотворений графа Хвостова: в 8 кн. СПб.: [б.и.], 1828. Кн. 1: Лирические стихотворения. С. 167-171.

Херасков М. М. Апрель // Херасков М. М. Избранные произведения. Л.: Сов. писатель, 1961. С. 136-137

Херасков М. М. Комета, явившаяся в 1767 году при начале войны с турками // Херасков М. М. Избранные произведения. Л.: Сов. писатель, 1961. С. 134-136.

\section{Исследования}

Белинский В. Г. Собр. соч.: в 3 т. М.: ОГИЗ ГИХЛ, 1948.

Бухаркин П. Е. Риторическое смыслообразование в «Вечернем размышлении о Божием величестве при случае великого северного сияния» М. В. Ломоносова. 
Между однозначностью логики и полисемией языка // XVIII век. СПб.: Наука, 2006. С6. 24. С. 35-56.

Виницкий И. Ю. Граф Сардинский: Дмитрий Хвостов и русская культура. М.: НЛО, 2016. 353 с.

Гаспаров М. Л. Стиль Ломоносова и стиль Сумарокова - некоторые коррективы // Новое литературное обозрение. 2003. № 1 (59). С. 235-243.

Либан Н. И. Русская литература: Лекции-очерки. М.: Прогресс-Плеяда, 2014. $584 \mathrm{c}$.

Лотман Ю. М. Беседы о русской культуре. Быт и традиции русского дворянства (XVIII - начало ХІХ века). СПб: Искусство-СПБ, 1994. 399 с.

Махов А. Е. Это веселое имя Хвостов // Граф Дмитрий Иванович Хвостов. Сочинения / сост. О. Л. Довгий, А. Е. Махов. М.: INTRADA, 1999. 224 с.

Остолопов Н. Ф. Ключ к сочинениям Державина, с кратким описанием жизни сего знаменитого поэта. СПб.: Тип. И. Глазунова, 1822.95 с.

Тьнянов Ю. Н. Архаисты и Пушкин // Пушкин и его современники. М.: Наука, 1968. C. $23-121$. 


\section{References}

Belinskii, V. G. Sobranie sochinenii: $v 3$ t. [Collected Works: in 3 vols.]. Moscow, OGIZ GIHL Publ., 1948. (In Russ.)

Bukharkin, P. E. "Ritoricheskoe smysloobrazovanie v 'Vechernem razmyshlenii o Bozhiem velichestve pri sluchae velikogo severnogo siianiia’ M. V. Lomonosova. Mezhdu odnoznachnost'iu logiki i polisemiei iazyka" ["Rhetorical Sense-making in 'Evening Meditation on the Majesty of God on the Occasion of the Great Northern Lights' by M. V. Lomonosov. Between Unambiguity of Logic and Polysemy of Language"]. XVIII vek [18 ${ }^{\text {th }}$ Century], vol. 24. St. Petersburg, Nauka Publ., 2006, pp. 35-56 (In Russ.)

Vinitskii, I. Ju. Graf Sardinskii: Dmitrii Hvostov i russkaia kul'tura [Count of Sardinia: Dmitry Khvostov and Russian Culture]. Moscow, NLO Publ., 2016. 353 p. (In Russ.)

Gasparov, M. L. "Stil' Lomonosova i stil' Sumarokova - nekotorye korrektivy" ["Style of Lomonosov and Style of Sumarokov - Some Corrections"]. Novoe literaturnoe obozrenie, no. 1 (59), 2003, pp. 235-243 (In Russ.)

Liban, N. I. Russkaia literatura: Lektsii-ocherki [Russian Literature. Lectures-Essays]. Moscow, Progress-Pleiada Publ., 2014. 584 p. (In Russ.)

Lotman, Iu. M. Besedy o russkoi kul'ture. Byt i traditsii russkogo dvorianstva (XVIII nachalo XIX veka) [Conversations about Russian Culture. Life and Traditions of the Russian Nobility (18 $\mathrm{B}$ - Early 19 $9^{\text {th }}$ Century)]. St. Petersburg, Iskusstvo-SPB Publ., 1994. 399 p. (In Russ.)

Makhov, A. E. "Eto veseloe imia Hvostov" [“This Funny Name Khvostov"]. Graf Dmitrii Ivanovich Hvostov. Sochineniia [Count Dmitry Ivanovich Khvostov. Works]. Moscow, INTRADA Publ., 1999. 224 p. (In Russ.)

Ostolopov, N. F. Kliuch $k$ sochineniiam Derzhavina, s kratkim opisaniem zhizni sego znamenitogo poeta [A Key to Derzhavin's Works, with a Brief Life Description of the Famous Poet]. St. Petersburg, Tipografiia I. Glazunova Publ., 1822. 95 p. (In Russ.)

Tynyanov, Yu. N. "Arkhaisty i Pushkin" ["Archaists and Pushkin"]. Pushkin i ego sovremenniki [Pushkin and His Contemporaries]. Moscow, Nauka Publ., 1968, pp. 23-121. (In Russ.) 


\title{
Символика времени и вечности в лирике природы Ф. И. Тютчева
}

\begin{abstract}
Аннотация: В статье исследуется малоизученный в литературной науке материал о Тютчеве, посвященный проблеме взаимосвязанности символики в произведениях поэта. На основе анализа стихотворений в статье доказывается, что соотношение времени и вечности (восходящее к античности) является главным смыслообразующим и связующим принципом символической системы Тютчева. Особое внимание автором статьи уделяется стихотворению «День и ночь». Приводимый в статье анализ стихотворений «Кончен пир», «Лебедь», «Душа хотела 6 быть звездой» позволяет понять, что время в лирике природы Тютчева постоянно ассоциируется с изменением и движением, которые характерны для низа («дольного мира», мира «дня»); вечность - с состоянием неподвижности и неизменности, характерными для удаленного от «дольного чада» верха - беспредельного пространства. Доказывается, что благодаря главной философской оппозиции время - вечность поэтом вводятся новые примеры противопоставлений, усиливается антитетический характер всей тютчевской системы. Символическая система Тютчева распадается на два иерархических уровня, каждый из которых представлен соответствующими звеньями оппозиций, за ними, в свою очередь, закрепляется определенная шкала ценностных значений, определяющих семантику времени и вечности.
\end{abstract}

Ключевые слова: Ф. И. Тютчев, античность, время, вечность, концепция истории, поэтическая система, оппозиции, античный пир, дольный чад, мифологическая структура.

Информация об авторе: Людмила Григорьевна Шакирова, кандидат филологических наук, старший научный сотрудник, Институт мировой литературы им. А. М. Горького Российской академии наук, ул. Поварская, д. 25 a, 121069 г. Москва, Россия

E-mail: sh_ludgrig@mail.ru

Дата поступления статьи в редакиию: 28.12 .2020

Дата одобрения статьи рецензентами: 15.03 .2021

Дата публикации статьи: 28.06.2021

Для цитирования: Шакирова Л. Г. Символика времени и вечности в лирике природы Ф. И. Тютчева // Два века русской классики. 2021. Т. 3, № 2. С. 62-95. https://doi.org/10.22455/2686-7494-2021-3-2-62-95 


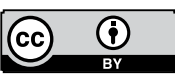

This is an open access article distributed under the Creative Commons Attribution

4.0 International (CC BY 4.0)
Dva veka russkoi klassiki,

vol. 3, no. 2, 2021, pp. 62-95. ISSN 2686-7494

Two centuries of the Russian classics, vol. 3, no. 2, 2021, pp. 62-95. ISSN 2686-7494

Research Article

(C) 2021. Ludmila G. Shakirova

A. M. Gorky Institute of World Literature of the Russian Academy of Sciences

Moscow, Russia

\title{
Symbols of Time and Eternity in F. I. Tyutchev's Nature Lyrics
}

\begin{abstract}
The article examines the poorly studied material concerning Tyutchev, dedicated to the interconnection of symbolism in the poet's works. Based on the analysis of poems, the article proves that the relationship between time and eternity (dating back to antiquity) is the main meaning-forming and connecting principle of Tyutchev's symbolic system. The author pays special attention to the poem Day and Night, the quintessence of the poet's worldview. The analysis of the poems The Feast is Over, The Swan, The Soul Would Like to Be a Star given in the article makes it possible to understand that time in the lyrics of Tyutchev's nature is constantly associated with the change and movement that are characteristic of the bottom ("dolny world", the world of "day"); eternity - with a state of immobility and immutability, characteristic of the upper, remote from the "dolny smoke" infinite space. It is proved that due to the main philosophical opposition between time and eternity, the poet introduces new examples of oppositions, and strengthens the antithetical nature of his entire system. Tyutchev's symbolic system splits into two hierarchical levels, opposite and at the same time interconnected with each other, each of which is represented by the corresponding links of oppositions, which, in turn, are assigned to a certain scale of values that determine the semantics of time and eternity.
\end{abstract}

Keywords: F. I. Tyutchev, antiquity, time, eternity, concept of history, poetic system, oppositions, antique feast, smoke, mythological structure.

Information about the author: Ludmila G. Shakirova, $\mathrm{PhD}$ in Philology, Senior Researcher, A. M. Gorky institute of World Literature of the Russian Academy of Sciences, Povarskaya 25 a, 121069 Moscow, Russia.

E-mail: sh_ludgrig@mail.ru

Received: December 28, 2020

Approved after reviewing: March 15, 2021

Published: June 28, 2021

For citation: Shakirova, L. G. "Symbols of Time and Eternity in F. I. Tyutchev's Nature Lyrics." Dva veka russkoi klassiki, vol. 3, no. 2, 2021, pp. 62-95. (In Russ.)

https://doi.org/10.22455/2686-7494-2021-3-2-62-95 
Почти все исследователи творчества Тютчева отмечали одну главную особенность символической системы поэта - взаимосвязанность всех ее элементов. Первые работы о поэзии Тютчева (Вл. С. Соловьева, С. Л. Франка, Д. С. Мережковского, 3. Дарского), по выражению В. Я. Брюсова, стремились «выявить философское содержание», т. е. пытались представить тютчевскую лирику как философское целое в своих концепциях. В итоге из символов поэта каждый произвольно возводил свою конструкцию ${ }^{1}$. Намеренная установка на системность без выявления объективно конструктивного принципа, управляющего системой и обеспечивающего взаимосвязанность системы на всех ее уровнях (в том числе и «философское содержание»), сводится лишь к толкованию лирики природы Тютчева на свой лад, что, по словам Д. С. Мережковского, «превращает алмаз в уголь». Система в итоге неизбежно оказывается субъективной концепцией самого исследователя, поскольку не выявляет природу взаимодействия отдельных стихотворений друг с другом, их объективную способность «прорастать» в систему множеством повторяющихся деталей, что ведет к возникновению циклических связей, которые в итоге и создают семантическое единство тютчевской лирики.

В ряде работ символику лирики природы Тютчева пытались объяснить постоянным кругом антитез (день - ночь, космос - хаос, зем-

\footnotetext{
1 Причем в большинстве работ, пользуясь философским языком, автоматически постулируется, что тютчевский комплекс идей сформировался под воздействием философии Шеллинга, поскольку и то, и другое натурфилософского содержания. Утверждение, закрепившееся в работах последних десятилетий, нуждается в серьезном пересмотре. Сама постановка проблемы символики немыслима без упора на мировоззренческие моменты, без выявления тютчевского комплекса идей и его соотнесенности с определенными философскими источниками. Тютчев создал на самом деле свою поэтическую модель мира на основе античной модели с сугубо присущими ей законами [Шакирова].
} 
ля - небо и т. д.), за которыми закреплялась определенная шкала ценностных значений. Исследователи, рассматривая те или иные антитезы (опять-таки не в их взаимосвязи!), говорили или о дуалистичности тютчевской поэтической системы (Б. Я. Бухштаб), или о ее диалектичности (Д. Д. Благой, К. В. Пигарев, Я. О. Зунделович), но ни в одной из работ не выявлялась причина появления многочисленных оппозиций в системе, в результате чего и возникала принципиально новая система образов, где их взаимодействие и взаимосцепляемость обеспечивались благодаря новому неожиданному ракурсу: весь художественный мир пропускался через время и вечность. Эта философская оппозиция и стала конструктивным принципом - формообразующим и содержательным - всей символической системы Тютчева.

В исследовательской литературе чаще всего в качестве «внутреннего стержня» в лирике природы Тютчева выделяли стихотворение «День и ночь», представляющее в целом художественно-философскую концепцию бытия [Боровская: 35-36]. Но почему все говорили лишь о полярности «дня и ночи», а на чем основана их космическая полярность у Тютчева, так и оставалось неясным.

Символика антитезы отнюдь не в том, что день (покров) скрывает сущность мироздания, а ночь открывает. В этом случае исследователями (начиная с В. Я. Брюсова) указывается лишь функиия покрова (что известно из содержания самого стихотворения).

Анализ стихотворений сводится многими исследователями к пересказу «близко к тексту» содержания тютчевских стихотворений, в итоге - к конкретизации, а вернее, к простой дешифровке символа, к потере его «смысловой перспективы». Исследователи рассуждают о поэтических афоризмах Тютчева [Голованевский, Сычёва], но, к сожалению, почти не соотносят символические ряды во множестве их перекличек и параллелей.

Если ограничиваться пределами только произведения «День и ночь», то глубинный смысл антитезы останется в тени. Его следует рассматривать, как и любое тютчевское стихотворение, лишь в соединении, во взаимодействии с другими. К тому же «День и ночь» можно назвать квинтэссенцией философского мировидения в том смысле, что оно является своего рода итогом, средоточием всего, что было создано до него. Поэтому стихотворение «День и ночь» можно поставить в смысловую связь с такими стихотворениями, как (назовем основ- 
ные) «Осенний вечер» (1830), «Mal’aria» (1830-х гг.?), «Яркий снег сиял в долине» (1836), «Весна» (1839), «Святая ночь на небосклон взошла» (1839).

Сущность «золотого покрова», «благодатной ткани» (жизни) раскрыта в «Mal'aria» (в предпоследней строке стихотворения все явления зримого мира называются также тканью: смерть ими «как тканью легкою свой облик прикрывает» [Тютчев 1965. 1: 44].

Все та ж высокая безоблачная твердь,

Все так же грудь твоя легко и сладко дышит,

Все тот же теплый ветр верхи дерев колышет,

Все тот же запах роз, и это все есть Смерть! [Тютчев 1965. 1: 44].

Через светлую ликующую картину земного мира просвечивает ужасающий в своей сверхреальности лик смерти, и спокойные беспечные повторения «все та ж», «все так же», «все тот же» теряют первоначальный смысл, столкнувшись с единственным словом, в котором, как в провале, как в пропасти, рушится все. Весь мир земной обречен смерти, потому что существует во времени. Потому у Тютчева время отождествляется со смертью, со «злом», через которое проходят все явления мира, поскольку существуют изолированно от целого. Слово «зло» всегда появляется там, где идет речь об отдельном существовании. Так, мифологическая Весна «не знает ... о зле», т. е. «игре и жертве жизни частной» [Тютчев 1965. 1: 96-97]. Не случайно третья строфа начинается отрицанием зла (индивидуального) и утверждением целого - «животворного океана» (море, океан, как мы помним, эквиваленты хаоса [Шакирова: 436]); «злая жизнь» вторгается в целое природы («Итальянская villa»). Многочисленные примеры еще раз свидетельствуют, что Тютчев идет вслед за Анаксимандром, утверждающим, что все обособившееся от целого «за свою нечестивость несет наказание и получает возмездие друг от друга в установленное время» [Античная литература: 12-13].

Таким образом, у Тютчева время есть и «зло», т. е. форма индивидуализации вещей (иначе говоря, бытие каждой вещи) и проявление «божьего гнева», т. е. движения внутри этой формы от жизни к смерти, которые здесь вступают в оксюморонные отношения: наиболее полное жизни одновременно и существует и не существует («есть смерть»). 
Сравним с оксюморонами Гераклита: «В одно и то же время мы существуем и не существуем»; «Всё, что мы, бодрствуя, видим, есть смерть» [Античная литература: 29].

Для «бездны безымянной» (или у Тютчева, как и у Анаксимандра, «беспредельности»), для основы мира (хаоса) не существует такой категории. Она вне времени, вечна, а потому, по Тютчеву, истинна ${ }^{1}$. Это представление восходит к мифологическому пониманию вечности. У Анаксимандра «эта природа (т. е. Беспредельное. - Л. Ш.) вечна и неизменна (нестареющая) и объемлет все миры. Время же <...> относится к области ограниченного рождения, существования и уничтожения» [Античная литература: 13].

Отношение Единого (хаоса) и Многого (упорядоченного космоса, т. е. «всего зримого» в стихотворении «Последний катаклизм») в античности, как видим, понималось как отношение времени и вечности. Поэтому антитеза «космос - хаос» в тютчевской лирике, как и в античной философии и литературе, является инвариантом оппозиции «время - вечность».

Время существует только для «золотого покрова». Все появляется, чтобы исчезнуть, все как «видение» проносится мимо:

Яркий снег сиял в долине, -

Снег растаял и ушел;

Вешний злак блестит в долине, -

Злак увянет и уйдет. «Яркий снег сиял в долине» [Тютчев 1965. 1: 80].

Течение времени рассматривается Тютчевым как путь разрушения, путь к смерти, как метаморфоза, превращение:

Когда, что так цвело и жило,

Теперь, так немощно и хило,

В последний улыбнется раз!..

«Обвеян вещею дремотой» [Тютчев 1965. 1: 128].

${ }^{1}$ См. стихотворение «Сон на море», где в предельно сконцентрированном виде дана идея хаотического как истинной вечной основы мироздания. Зримая внешность мира рассматривается Тютчевым как беспредельная фантазия человеческого воображения, развивающаяся в пространстве и противопоставляемая истинной реальности - «гремящей тьме», хаотической стихии. 
Но для Тютчева время выступает не только в роли истребителя бытия. Течение времени связано одновременно и с созиданием. Время означает изменение. В течении времени выражается движение. Вечно изменяющийся мир во времени - это мир в движении (от бытия к небытию). Тютчев изображает становление в традициях гераклитианской диалектики ${ }^{1}$. Все чередует собой лишь цепь бесконечных превращений:

Но с новым летом новый злак

И лист иной.

И снова будет все, что есть,

И снова розы будут цвесть,

И терны тож... «Сижу задумчив и один» [Тютчев 1965. 1: 70].

В этом смысле весна (вечное возрождение) и осень (функция, близкая функции смерти) - символы «золотого покрова», циркулирующего времени.

Все явления «внешнего» мира - это море бытия в круговратном бесплодном движении («тот же все вечный прибой и отбой»), и волны его плещут в вечном и утомительном однообразии: по сути, вечное повторение одних и тех же содержаний в мире. В этом смысле «золотой покров» (день) вечен и может относительно мирно сосуществовать с ночью, поэтому ночь срывает покров не однажды и не окончательно, а вечно. Борьба дня и ночи гарантирует вселенский порядок, т. е. единоборство противоборствующих сил. Но главенство ее по отношению к дню в том, что она открывает вечную основу мироздания - хаос и в этом смысле сопричастна вечности (в стихотворении «Святая ночь на небосклон взошла...» святая - значит божественная, слитная с главным божеством - хаосом, а божество и вечность у Тютчева - синонимы).

Таким образом, мы имеем два полярно противоположных символа: космический день - символ времени и ночь - символ вечности. По-

\footnotetext{
1 Гераклит - первый философ, усмотревший сущность наличного мира в его движении. Его знаменитая философема: «Нельзя в одну и ту же реку войти дважды» отразилась в тютчевской лирике: образ вечно бегущей струи в стихотворениях «Что ты клонишь над водами», «Успокоение» символизирует вечно изменчивую суть мира.
} 
этому антитеза день - ночь символична, это антитеза времени и вечности, по Тютчеву одновременное сосуществование двух противоположных состояний в мироздании, отражающие меру его постоянства и обусловленности. Время, по Тютчеву, относится к области упорядоченного становления (для которого характерна постоянная изменчивость явлений, выражающаяся в движении и характеризующая в то же время непрерывность времени), существования (говорящего о направленности времени) и уничтожения.

Этот процесс постоянных изменений идет через бесконечные периоды повторения, что обеспечивает вечность земного мира и его подвижное равновесие. Жизнь мира, «как океан безбрежный, / Вся в настоящем разлита», не ведая былого («Весна»: «Не о былом вздыхают розы»). Истинно сущая природа совмещает в себе два бытия: неизменное и изменчивое, вечность и время. На время переносятся свойства вечности, которая проявляет себя в непрекращающемся движении природы:

Чудный день! Пройдут века

Так же будут в вечном строе,

Течь и искриться река

И поля дышать на зное. «В небе тают облака» [Тютчев 1965. 1: 215].

Вечно текучая неделимая стихия жизни дается в виде постоянного круговорота элементов. Реалии природы (злак, снег, розы, небо Рима, река и т. д.) в таких стихотворениях становятся символами циркулирующего (т. е. бегущего по кругу) времени, символами «золотого покрова» ${ }^{2}$ Таким образом, в лирике природы Тютчева можно наблюдать своеобразную диалектику времени и вечности которая выражается в том, что в одних случаях говорится об уничтожимости и конечности во времени каждого явления мира (перечисление в «Mal'aria») и мира в целом, поглощение космоса хаосом, и в то же время утверждается временная бесконечность и неуничтожимость мира в целом, так как вечен первоисточник его жизни - хаос. Мир одновременно и вечен, и не вечен. (С другой стороны, мир изменяется и в то же время находится под

1 Циклическое время всегда характеризует бытие ограниченное и замкнутое и в пространственном отношении (см. «яркий снег сиял в долине, ...вешний злак блестит в долине...»). Подробно об этом ниже. 
знаком неподвижности). В этой внутренней раздвоенности - тайна единого бытия.

Исходя из этого, можно говорить, что в лирике природы Тютчева воспроизведено античное соотношение времени и вечности. Как и в античности, вечность у Тютчева выступает как источник всеобщего возникновения и уничтожения, поскольку хаос у Тютчева оказывается «родимым»: «О страшных песен сих не пой / Про древний хаос, про родимый» («О чем ты воешь, ветр ночной?») [Тютчев 1965. 1: 57] или как в стихотворении «Святая ночь на небосклон взошла», хаос - «наследье родовое», все из себя порождающий, все в себя вбирающий («Последний катаклизм») [Тютчев 1965. 1: 22]. «Все эманирующее из чего-то по сущности возвращается к тому, из чего эманирует» [Антология: 559]. «Все зримое опять покроют воды» первобытного хаоса, после чего будет возможным новое существование мира во времени, т. е. новое круговращение времени и связанного с ним мирового становления, и эта смена совершается периодически в течение всей вечности. Итак, вечность у Тютчева сводится к бесконечной последовательности круговоротов времени. Возникает структура, подобная мифологической. В частности, тютчевская концепция времени обнаруживает явное тяготение именно к платоновской концепции, не избежавшей мифологического влияния: «Поэтому он (Бог. - Л. Ш.) замыслил сотворить некое движущееся подобие вечности (т. е. время. - Л. Ш.)... Все это части времени, а “было” и “будет” суть виды возникшего времени, и, перенося их на вечную сущность, мы незаметно для себя делаем ошибку. Ведь мы говорим об этой сущности, что она “была”, “есть” и “будет”, но, если рассудить правильно, ей подобает одно только “есть”, между тем как “было” и “будет” приложимы лишь к возникновению, становящемуся во времени, ибо и то и другое суть движения. Но тому, что вечно пребывает тождественным и неподвижным, не пристало становиться со временем старше или моложе, либо стать таким когда-то, теперь или в будущем, либо вообще претерпевать что бы то ни было из того, чем возникновение наделило поток данных в ощущении вещей. Нет, все это - виды времени, подражающего вечности и бегущего по кругу согласно законам числа» [Платон: 477]. Здесь содержатся очень важные для Тютчева характеристики времени и вечности.

Странно, как не замечено было исследователями, что это платоновское время как «подвижный образ вечности» уже присутствует в 
юношеском стихотворении Тютчева «На новый 1816 год» («О время, Вечности подвижное зерцало!»).

Идея кругового движения характерна более всего для Античности, поскольку сами античные философы не могли выйти за рамки античного мифологического мышления. Именно поэтому античный мир не создал философии истории. Средневековье переняло от Античности общую идею соотносимости времени и вечности (которая трансформируется в противопоставление временного, мирского и вечного, божественного), но не саму идею цикличности. «В вечном, - по словам Августина Аврелия, - нет ни преходящего, ни будущего, ибо что проходит, то уже перестает существовать, а что будет, то еще не начало быть. Вечность же только есть, она ни была, как будто ее уже нет, ни будет, как будто доселе ее еще не существует» [Антология: 59]. Августин отвергает концепцию циклического времени (правда, на почве центральной догмы христианства), поскольку оно регрессивно и ничего не дает для объяснения истории, события которой уникально неповторимы (в частности, продолжением своего существования циклизм, с точки зрения Августина, опровергал бы уникальность главного исторического события - распятия Христа). Его время линейно, одновекторно и необратимо. «Новое сознание времени опирается на три определяющих момента: начало, кульминацию и завершение жизни рода человеческого. Время становится векторным, линейным и необратимым», - отметил А. Я. Гуревич [Гуревич: 100]. Эта необратимость времени станет основным моментом всех последующих концепций времени, время в них предстает как исторически направленное в сторону будущего, динамично развивающаяся структура. Так, например, в стихотворении С. П. Шевырева каждая последующая эпоха ставится на более высокую ступень, чем предшествующая:

Мир бысть - прошли века, но в каждое мгновенье

Да будет! - оглашает свет,

И человек за все творенье

Дает творящему ответ.

Я есмь («Да будет! — был глагол творящий») [Шевырев: 1].

История дана у Шевырева как прогресс разума (для Тютчева, сомневающегося в ценности рационального познания, - при постоянной 
текучести познание невозможно - прогресс разума вряд ли был критерием). Вера в прогресс истории - вот что характерно для концепций любомудров. История человечества имеет какую-то цель, а каждая последующая эпоха свое назначение в рамках осуществления этой цели. Идея была воспринята ими от Шеллинга, для которого история - саморазвитие абсолюта: «История в качестве целого представляется беспредельным и постепенно осуществляющимся откровением абсолюта» [Шеллинг: 356]. Модель истории Шеллинга заключала в себе элементы поступательного развития, которое дает всегда новое содержание.

Собственно, мысли о развитии как поступательности, качественном возвышении были теми новыми мыслями для любомудров, впервые блеснувшими в Германии. Эволюционная лестница Шеллинга (непрерывный ряд ступеней, восходящий от самого простого звена природы до самого сложного явления-произведения искусства) - образ, наиболее часто встречающийся в высказываниях любомудров в 1820-х гг. (Можно привести в пример рассуждения В. Ф. Одоевского о приготовленности каждого века предыдущим, о восхождении человеческого общества к «зрелости», о «лествице форм духа»). У Д. В. Веневитинова человечество и народ движутся вперед в процессе самопознания от «века золотого» в прошлом к «веку золотому» в будущем [Веневитинов: 133-134]. Есть несомненная перекличка не только с Шеллингом [Шеллинг: 394], но и с Новалисом, с его пониманием триадного развития: «...переход из сих эпох в другую должен быть постепенным и во всякой эпохе отражаются две другие» [Веневитинов: 304].

И вот здесь намечается явное концепционное несходство Тютчева и Шеллинга (Тютчева и любомудров). Тютчевская концепция истории обнаруживает тяготение к античной концепции «философии истории» (конечно, в данном случае можно лишь условно применить эту терминологию), т. е. цикличной в своей основе. Мифологическому сознанию понятие истории было чуждо. История и есть развитие. Где движение происходит в виде лишь простого повторения одного и того же (в итоге картина мира одна и та же, т. е. неподвижна), там нет и не может быть истории. (Это объясняется тем, что время ушедших поколений во всех случаях рассматривается им не в плане историческом, а в плане философском, что они значат по сравнению с вечностью, и, как правило, в соотношении с вечностью Тютчев демонстрирует суетность человеческой истории.) 
Концепция цикличности природных процессов будет распространяться Тютчевым и на понятие истории. Попытаемся доказать это на примере стихотворения «Кончен пир, умолкли хоры...»:

Кончен пир, умолкли хоры,

Опорожнены амфоры,

Опрокинуты корзины,

Не допиты в кубках вины,

На главах венки измяты,

Лишь курятся ароматы, -

В опустевшей светлой зале...

Кончив пир, мы поздно встали -

Звезды на небе сияли,

Ночь достигла половины...

Как над беспокойным градом,

Над дворцами, над домами,

Шумным уличным движеньем

С тускло-рдяным освещеньем

И бессонными толпами, -

Как над этим дольным чадом,

В горнем выспреннем пределе

Звезды чистые горели,

Отвечая смертным взглядам

Непорочными лучами... [Тютчев 1965. 1: 122]

Стихотворение внешне разбивается на две симметричные части. Но детальный его анализ показывает, что в смысловом отношении каждая часть тоже членима, так как построена на противопоставлении двух временных планов. В первой части статичная конструкция (перечисление завершившихся во времени действий без указания, кем эти действия совершались) заменяется динамичным словосочетанием «мы встали», в котором обозначены лица, только что совершившие действие. Все эти наблюдения приводят к мысли, что речь идет о двух различных пирах. Многоточие в данном случае скрепляет два этих повествовательных куска. К тому же оба пира различны по своей продолжительности: «светлая» зала свидетельствует о наступлении утра; 
второй пир завершается «поздно», когда «ночь достигла половины». Если бы мы сочли, что первая часть стихотворения заключает в себе описание лишь одного действия (конец какого-то одного пира), то это описание воспринималось бы иронически, потому что употребляемая здесь античная лексика (хоры, амфоры, венки измяты, курятся ароматы) создавала бы лишь комический эффект при описании какого-то современного действия. Но мы понимаем, что в первой части явное противопоставление двух далеко отстоящих друг от друга во времени действий, одно из которых принимается за начало отсчета времени в стихотворении. Тогда становится понятным значение в контексте античных слов, слов-символов, вызывающих у нас ассоциацию давно отшумевшего античного пира.

Многоточие после описания античного пира создает большую смысловую паузу и, как видим в дальнейшем, фиксирует переключение временной позиции. В первой же строке «Кончив пир, мы поздно встали» повторяются первые два слова, что были в самом начале стихотворения. Приостановленное действие как бы продолжает развиваться во времени, но мы понимаем, что это продолжение уже иного времени. Это подтверждается во второй части стихотворения, где рисуется город, напоминающий скорее современный, а не античный («беспокойный град» с «шумным уличным движеньем, с тускло-рдяным освещеньем»).

Таким образом, эти два временных плана составляют в стихотворении единый символический ряд. Они строят единый символ времени, обозначающий здесь быструю смену человеческих поколений. (Два пира - два звена в цепочке поколений. Смысловая пауза, обозначенная многоточием в первой части, разделяющая два временных момента, как бы заключает в себе намек на огромный промежуток времени, промелькнувший между ними.)

Две части стихотворения разделены между собой тоже многоточием, в данном случае обозначающим переключение уже не временной позиции, а пространственной (т. е. переключение зрительной позиции с тесной залы на град, позволяющей запечатлеть динамику града).

Вторая часть стихотворения являет собой противопоставление само по себе символическое: «дольный чад» и картина ночного неба, вводящая в стихотворение ощущение безмерного безграничного пространства. «Дольный чад» является здесь не столько обобщением гра- 
да с «шумным уличным движеньем», сколько обобщением пребывавших в нем и успевших исчезнуть цивилизаций (строка «как над этим дольным чадом» обобщает ранее проводившееся противопоставление временных планов). В сравнении с беспредельностью вечности, пространства веков оказываются сведенными к нулю, одной ничтожной точке, именуемой «дольным чадом». Таким образом, совершается перевод категории времени и вечности на язык пространства и обратная зависимость - постепенный переход от одного пространства, от «дольного чада», в котором тоже есть свои переходы: зала - град, к другому - «горнему выспренному» ${ }^{1}-$ означает переход от временного к вечному. Тютчев противопоставляет низ и верх (с этической точки зрения) как время и вечность (поэтому антитеза «низ - верх» будет являться вариантом оппозиции «время - вечность»).

Низ («дольный чад») характеризуется в прямом смысле как отсутствие простора, воздуха и чистоты. Мир низа (дня) - мир не прекращающегося ни на мгновение движения и изменения и природного (сезонного) и человеческого. Все, принадлежащее низу (дню), преходяще, текуче, подвергается распаду, тлену... чаще всего вод воздействием «багровых лучей», зноя, жары. Поэтому «зной» и «прах» могут даже оказаться в одном синонимическом ряду: «На мне, я чую, тяготеет Вчерашний зной, вчерашний прах!..» [Тютчев 1965. 1: 65]; «жизни некий преизбыток в знойном воздухе разлит» [Тютчев 1965. 1: 59] или другой пример: «та злая жизнь с ее мятежным жаром» [Тютчев 1965. 1: 91], где жизнь и жар сливаются воедино: «мятежный жар» - горение жизни, разрушение ее, иначе говоря, жизнь, уже заключающая в себе смерть, зло (отчасти та же конструкция, что и в «Mal'aria»). Эта устойчивая связь зноя и жизни явно из Библии. Так в Откровении Иоанна сказано: «Они не будут уже ни алкать, ни жаждать и не будет палить их солнце и никакой зной» (Откр. 7: 16). Поэтому «дольный мир», тесный и замкнутый в пространственном отношении, расценивается как «дольный чад», т. е. нечистый, порочный (вследствие своего непостоянства и изменения) и, таким образом, греховный, несущий в себе время, в отличие от

1 В словаре Даля: горний - высший, верхний, небесный; выспренный высокий в значении удаленного от поверхности земли, горний и духовно возвышенный. С высотой у Тютчева всегда ассоциируется радость: «Вот взобрался я на вершину, Сижу здесь радостен и тих» («Какое дикое ущелье»); «Деревья радостно трепещут, купаясь в небе голубом» («Сияет солнце, воды блещут») [Даль 1: 316]. 
«горнего» мира («Там в горнем неземном жилище, где смертной жизни места нет»). Отсюда ясно сочетание двух признаков, характеризующих звезды - «чистые» и «непорочные» т. е. не имеющие признаков мгновенности, смерти, тленности, вне греха изменения, поэтому «чистый» и «непорочный» сливаются в некоторое семантическое единство со значением «неизменный» (вечный). «Чистое» бытие верха как бы застыло в своей неподвижности, в своем субстанциальном безразличии ко всему, что происходит в земном мире: «Но который век белеет / Там, на высях снеговых» [Тютчев 1965 1: 82]. Что вне движения, вне превращений, то вечно. Что вечно, то божественно и непорочно. На горах, замкнутых в своем «вечном настоящем» «вдруг просветлеют огнецветно их непорочные ${ }^{1}$ снега». Пространственная высота гор ассоциируется с вечностью, поскольку они ближе к звездным мирам, к бесконечности. Особую роль играют в стихотворениях Тютчева деревья. Через их образ в строй стихотворения также входит вечное начало. Ведь их вершины купаются в небе, их шум - голос выси, голос вечности. Тютчевский текст как бы устанавливает романтическую субординацию ценностей: все, составляющее семантическую группу вечности, наделяется более высокими с этической точки зрения характеристиками, в данном случае - чистота, непорочность, неизменность. Таким образом, звезды, наделенные этими признаками, символизируют вечность, пред ними проходят чередой все цивилизации ${ }^{2}$. (Античный пир - символ ушедшей цивилизации, символ завершения одного из циклов истории.)

Фукидид говорил, что его целью является показ того времени, когда «будущее когда-нибудь повторится как одинаковое... минувшее может по свойству человеческой природы повторится когда-нибудь в будущем в том же самом или подобном виде» [Фукидид: 16].

В стихотворении «Кончен пир, умолкли хоры...», имеющем непосредственным объектом изображения всемирную историю, история

${ }^{1}$ Слова, употреблявшиеся в одном тексте, привносят в новый всю полноту смысла, ранее заключавшегося в них (происходит своего рода «циклизация» лексемы) и благодаря ассоциативному принципу приобретают символическое звучание, поскольку символизируются в процессе движения поэтической мысли.

2 Символическое значение в стихотворении приобретает и такая деталь, как «половина ночи» (в строке «ночь достигала половины»). В одном из ранних стихотворений - это «час явлений и чудес» т. е. час, когда очевиднее всего являет себя вечность. 
человечества представляет собой дублирование одних и тех же событий, что символизирует повторяемость и в конечном итоге неизменность истории (а мир истории, по общепринятому мнению, - это мир, где появляется новое, небывалое в прошлом. Сравним у Гете: «Зрелище ее вечно ново, ибо она создает все новые и новые явления и новых созерцателей» [Гете: 38].

История, таким образом, распадается на равные циклы ${ }^{1}$, и время человечества, аналогично природному (космическому) времени, движется по кругу, извечно повторяя уже пройденное: «Мужайтесь, боритесь...» «над вами» будут все те же «светила», «под вами» все те же «могилы». «Два голоса» [Тютчев 1965 1: 129].

В настоящем повторяется прошедшее и в итоге бесконечный процесс бессмысленного движения: «борьба безнадежна». Меняются лишь статисты («свершающие свой подвиг бесполезный»), что у Тютчева составляет суть истории:

И новое, младое племя

Меж тем на солнце расцвело «Бессонница» [Тютчев 1965 1: 18];

Как грустно полусонной тенью

За новым племенем брести «Как птичка раннею зарей» [Тютчев 1965. 1: 65];

Где новые садятся гости

За уготованный им пир².

«Когда дряхлеющие силы» [Тютчев 1965 1: 209].

Любопытно, что антитеза «верх - низ», употребляемая дважды в стихотворении «Два голоса», выполняет при этом различные функ-

\footnotetext{
${ }^{1}$ Цикл завершается катаклизмом - погружением в хаос, ночь (см. в «Цицероне» - «ночь Рима». Катастрофа, таким образом, знаменует переход к новому циклу. Исторический реальный материал содержится в поэзии Тютчева только в стихотворениях «на случай» и, как правило, дается как нелогичный, непостижимый. Об этом свидетельствует часто употребляемое слово «роковой», т. е. предопределенный (см. строки в стихотворении «1856»: «Стоим мы слепо пред Судьбою» ... «Слова неясны роковые»).

2 Целую концепцию истории несет одно лишь слово «пир», «кочующее» из одного стихотворения в другое и таким образом превращающееся в устойчивый символ.
} 
ции. В первой строфе уравнение верха и низа («молчат» равно и «светила», и «могилы») диктуется необходимостью создания нейтрального фона для восприятия другого противопоставления: предопределенного «блаженства» богов, свободных от «труда и тревоги», т. е. всего временного, а потому и «бессмертных» и предопределенность «конца» для «смертных сердец». Таким образом, уравнивание членов первой оппозиции было необходимо для противопоставления смертного бессмертного, временного - вечного. Кроме того, на фоне созданных «декораций» выявились участники предстоящего действа - «боги» в качестве зрителей и "други», которым предстоит участвовать в неравном поединке. С кем будут сражаться «други», пока неясно. Во второй части стихотворения верх уже не связан с низом: уравненное молчание в первой строфе не идентично молчанию в третьей строфе, где верх «безмолвный» (семантическая группа вечности пополняется новым значением), т. е. преисполненный горделивого величия (ср. с «безмолвной славой» в значении «вечной славой» в стихотворении «Рим ночью»), а низ - «немой», исключающий какую-либо возможность коммуникации, что подчеркивается введением дополнительного признака - «глухой». В одном случае молчание - высокомерное отчуждение, нежелание общения с неравным себе, в другом - молчание как результат крайне жалкого положения низа. По отношению к верху (природе) низ (прошлая история поколений) получает признаки низшей иерархичности. Отсутствие контакта между современным человеком, природой и предшествующими поколениями еще более подчеркивает полное одиночество человека (где нет сочувствующих) в борьбе с обозначившимся наконец-то врагом - Роком, Необходимостью, чья воля и устанавливает извечность круговоротов природы и человеческой истории, и по чьей воле происходит разрыв временного и вечного. Верх и низ теряют значение фона, становясь, вместе с богами, зрителями с разной степенью восприятия трагической борьбы человека с Роком, с высшей силой, управляющей миром, которой нет объяснения причинности ${ }^{1}$, кото-

1 Тютчев, как видим, последовательно оперирует античными понятиями. См. у Анаксимандра и Гераклита: «Также он принимает некоторый порядок и определенное время для перемены мира согласно роковой необходимости» [Антология: 24]. Но в Античности человек - безответное оружие Рока, у Тютчева - в борьбе с Роком. Это расхождение - весьма важное свидетельство начавшегося крушения созданной в 1820-1830-е гг. пантеистической конструкции. 
рой не смеют противиться даже боги, а потому и глядят «завистливым оком» на борьбу «непреклонных сердец». Очевидно, дарованное Роком «блаженство» прескучило им вконец. Не сломленный духом побеждает - так утверждает второй голос необходимость и тем самым ценность отдельной человеческой жизни как подвига (не снимая при этом тезиса о бессмысленности всеобщей человеческой истории пред ликом Вечности), сведя на нет саркастическую иронию первого голоса: «боритесь прилежно» (заранее предписанный автоматизм действий в мире предопределенности и тем самым бессмысленность человеческой жизни выражается посредством парадоксального сочетания двух взаимоисключающих понятий: «прилежно», т. е. «послушно» со значением пассивности и «боритесь» со значением активности действия).

Итак, оппозиция время - вечность в анализируемых стихотворениях реализуется через пространственные оппозиции верх - низ (горнее - дольнее, земля - небо) и тесно - безгранично («звездные круги» - интенсивно раздвигающаяся разнонаправленная бесконечность противопоставляется однолинейному плоскостному пространству низа). Это пространственное противопоставление времени и вечности с наибольшей силой развертывается в стихотворении «Лебедь».

Пускай орел за облаками

Встречает молнии полет

И неподвижными очами

В себя впивает солнца свет.

Но нет завиднее удела,

О лебедь чистый, твоего -

И чистой, как ты сам, одело

Тебя стихией божество.

Она, между двойною бездной,

Лелеет твой всезрящий сон -

И полной славой тверди звездной

Ты отовсюду окружен [Тютчев 1965 1:26].

Полет орла совершается в пространстве, граница которого - «солнца свет» (или «палящие солнечные лучи» в стихотворении «Душа хоте- 
ла б быть звездой»). Жар, зной, духота гибельны для всего земного, для мира дня («пламенного» дня), для мира времени. Это предел, положенный орлу, его «высота заветная», преодолеть которую он не в силах. Удаляясь от земли, от мира превращений, он неизбежно остается его пленником. Орел Ротчева ${ }^{1}$, «презирающий узы праха», в тютчевском тексте сам становится «прахом».

Для лебедя нет предела - он в бесконечности - охвачен «славой тверди звездной» (т. е. вечностью. «Слава», как мы помним, удел вечности) и более того, «полной» славой «отовсюду» пространственно окружен. Всеокруженность «звездной славой» (звезды вверху и внизу, отражаясь в воде, на которой покоится лебедь, и есть та «двойная бездна» $\left.{ }^{2}\right)-$ это уже полное_субстанциальное пребывание в вечности. Если с вечностью у Тютчева постоянно ассоциируется состояние неподвижности, а время связано с движением (платоновский принцип), то понятно, почему образ, охваченный вечностью, может подаваться только в состоянии абсолютного покоя - «сна» (ведь о полете лебедя не сказано ни слова), и сон лебедя характеризуется как «всезрящий сон». Всезрящий - качество, не доступное орлу; он видит «недвижными очами» (т. е. направленными в одну точку) лишь «солнца свет», так как все видеть, перемещаясь в пространстве, нельзя (что еще лишний раз доказывает пространственно-временную ограниченность его деятельности), а только, подобно лебедю, в состоянии абсолютного покоя, будучи неподвижным центром всеохватывающей «стихии» божества. Как видим, семантические поля лебедя и орла неадекватны. Каждое из них «конструирует» своего героя.

«Всезрящий», всевидящий - так говорят о Боге. Стало быть, лебедю приписываются функции божества, помимо дополнительного признака божественности: «чистый», под которым здесь подразумевается также и цвет: белый, т. е. светлый. Светлое у Тютчева постоянно ассоциируется с божеством: «Киприда светлая всплыла» (в стихотворении «Давно, давно ль, о Юг блаженный» [Тютчев 1965 1: 92]), весна «светла... как подобает
1 Я с ранних дней привык без страха
Парить к безоблачным странам
Я презираю узы праха!
Я близок силою к богам!
Стихотворение А. Г. Ротчева «Гармония» полностью приводится в книге Ю. Н. Тынянова «Архаисты и новаторы» [Тынянов: 364-365].
${ }^{2}$ Сравним: «И мы плывем, пылающею бездной со всех сторон окруже- ны» в стихотворении «Как океан объемлет шар земной». 
божествам» [Тютчев 1965 1: 96]. Ассоциативные переклички с Библией, часто употребляющей белый цвет в значении святости, непогрешимости, чистоты, здесь очевидны. В Откровении Иоанна читаем: «...а на престолах видел я сидевших двадцать четыре старца, которые облечены были в белые одежды и имели на главах своих золотые венцы» (Откр. 4: 4); «великое множество людей... стояло пред престолом и Агнцем в белых одеждах и с пальмовыми ветвями в руках своих...» (Откр. 7: 9)1.

Таким образом, противопоставление лебедя орлу в высшей степени контрастно, поскольку они принадлежат различным мирам. Антитетичность их семантических полей есть по сути противопоставление времени и вечности. Как указывал Ю. Н. Тынянов, «сопоставление (семантическое) орла с лебедем было излюбленным в европейской поэзии, причем в этом символическом состязании побеждал орел. У Тютчева победа за лебедем» [Тынянов: 365]. Это стало возможным благодаря переводу «типовой» антитезы в философский план. У А. Г. Ротчева антитеза подается как проблема соотношения двух этических норм жизни: деятельной жизни орла и тихой «незаметной» созерцательной жизни лебедя.

Итак, на основании анализируемых текстов можно сделать вывод, что оппозиция время - вечность включает в себя несколько стабильных конструкций, которые можно представить следующим образом:

Время (как форма существования индивидуальных вещей

|

Космос

|

День

1

Низ («дольный мир»)

Тесное замкнутое пространство
Вечность (как форма существования Единого)

|

Хаос (Единое)

|

Ночь

|

Верх («горный мир»)

|

Беспредельность

1 Анализы тютчевских текстов приводят подчас к неожиданным наблюдениям. У Тютчева с миром дня, зноя - с миром времени - чаще всего связываются огненные, «знойные» цвета: «багровый», «багряный», «пламенный» или же «зловещий» блеск и пестрота красок: «Зловещий блеск и пестрота дерев» («Обвеян вещею дремотой»); «гляжу тревожными глазами на этот блеск, на этот свет» («Лето 1854»); «О, этот Юг, о, эта Ницца!.. О, как их блеск меня тревожит!» Для мира вечности характерна однородность цвета, в основном используется светлый, а также все оттенки «небесного»: «голубой», «лазурный», «лазоревый». 
и является тем основным конструктивным связующим принципом, вызывающим к жизни, помимо этих, новые бинарные оппозиции, звенья которых будут также семантически взаимосвязаны. Одновременно от развертывания главной философской оппозиции в вариантных антитезах зависит появление тех или иных символов.

В лирике природы Тютчева на всех оппозиционных уровнях вечность характеризуется такими состояниями, как, неподвижность, неизменность, высота (удаленность в пространстве от «дольного чада»), глубина (не только расширение пространства, но и интенсивная его углубленность: «Небесный свод... таинственно глядит из глубинь»»; «в бездомном небе звездный сонм горит» и т. д.), чистота (нетленность, непорочность, одноцветность), тишина и безмолвие («Есть некий час в ночи всемирного молчанья»; в др. дословно: «Кто без тоски внимал из нас / Среди всемирного молчанья»; «Туда взлетая,

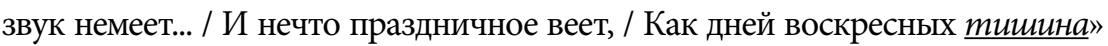
(курсив мой. - Л. Ш.)).

Поэтому все, что связывается с одним из этих состояний (или несколькими одновременно), представляется Тютчеву вечным.

Если с вечностью у Тютчева постоянно ассоциируется состояние неподвижности («А там в торжественном покое... сияет Белая гора») и Тютчев противопоставляет вечность как что-то неподвижное, как неподвижную длительность течению времени ${ }^{1}$, то понятно, почему он находит элементы вечности в неподвижных руинах, когда рисует упадок и безмолвие некогда могущественного Рима. Руины - это все, что осталось от исчезнувших цивилизаций (это и ответ на ранее задававшийся вопрос: «Что уцелело, что дошло до нас» во времени от ушедших поколений: см. стихотворение «Через ливонские я проезжал поля»). Любопытно сравнить два «римских» стихотворения Тютчева и Шевырева:

В ночи лазурной почивает Рим.

Взошла луна и овладела им,

И спящий град, безлюдно-величавый

Наполнила своей безмолвной славой ...

${ }^{1}$ В стихотворении «Итальянская villa» (1837):

И мы вошли ... все было так спокойно,

Так все от века мирно и темно!..

через символическое противопоставление двух состояний передана основная коллизия стихотворения: человеческое время и вечность несовместимые понятия. 
Как сладко дремлет Рим в ее лучах!

Как с ней сроднился Рима вечный прах!..

Как будто лунный мир и град почивший -

Все тот же мир, волшебный, но отживший!..

«Рим ночью» (1850) [Тютчев 1965. 1: 120].

Когда в тебе, веками полный Рим,

По стогнам гром небесный пробегает,

И дерзостно раскатом роковым

В твои дворцы и храмы ударяет:

Тогда я мню, что это ты гремишь

Во гневе прах столетий сотрясаешь

И сгибами Виссона шевелишь,

И громом тем Сатурна устрашаешь.

«К Риму» («По лестнице торжественной веков») [Шевырев: 80].

В сознании Шевырева в отношении к римской теме всегда присутствуют три момента: 1) Рим, шедший к славе «по лестнице торжественной веков»; 2) «и пал гигант»; 3) «но путь торжеств еще не истреблен» (устанавливается преемственность между эпохами). Таким образом, Шевырев решает тему с романтических позиций в историческом, а не философском, подобно Тютчеву, ключе, поэтому, в сравнении с тютчевским, стихотворение Шевырева не заключает в себе никакой символики. Гром - лишь метафора былого величия Рима ${ }^{1}$. Но в тютчевском стихотворении традиционный образ, попадая в стихию взаимосвязанных символов, вступает с ними в неожиданные смысловые контакты, символизируясь сам, т. е. подчиняясь уже установившимся законам символической системы. Строка «Как с ней сроднился Рима вечный прах» - смысловой центр стихотворения. Если ночь у Тютчева всегда ассоциируется с вечностью, то Рим «безлюдно-величавый», сроднившись с ночью, в данном случае является символом вечности. «Величавым» может быть только «безлюдный» град, в отличие от града в стихотворении «Кончен пир, умолкли хоры...». В нем отсутствует движение и все, что имеет отношение к

${ }^{1}$ Сравним у Майкова стихотворение "Сampagna di Рота" - развалины Рима наводят на мысль об упадке нравов в современной Италии: «Вот она - Италия святая!» 
миру дня, к миру времени: «шум... говор, крики», «толпа» - суета, поэтому здесь царствует покой. Луна заполняет его «безмолвной славой», т. е. величавым вечным молчанием. Поэтому все стихотворение рисует «волшебный мир» вечности, с которым сроднился «спящий» Рим. Его прошлое «дремлет» в настоящем. Полная неразличимость моментов (прошлого, настоящего и будущего), отсутствие последовательности и их движения (т. е. всего того, что характеризует однолинейное время, когда имеют в виду его «течение») - вот что свойственно вечности, в которой все сосуществует в «бесконечно длящемся настоящем». Поэтому о совершающемся действии, а вернее бездействии Рима, говорится только в настоящем времени: «почивает», «дремлет» его «вечный прах». Прошлое и настоящее в ночи хаоса не различимы, «сроднились». Уже в раннем стихотворении «Проблеск» «полуночь» пробуждает «ненароком» прошлое «дремавших струн» или в стихотворении «Арфа скальда» лазурный свет луны заставляет «давно минувший» вториться мотив. Ко всему, что связано у Тютчева с хаосом и ночью, не приложимы временные ограничения, так как там, где отсутствует время, невозможно определить длительность действия. Неизвестно, как долго «почивает» Рим, как «долго спала в ночи» арфа скальда, итальянская вилла (предполагается неопределенно, что «века два тому иль боле»). В этом отношении интересно стихотворение «Еще шумел весенний день». Переход из мира «пышно-золотого», полного движения и «звуков жизни благодатной», т. е. мира времени в мир «царства теней», «покоя» и «молчанья» (даже «солнце» заменяется абстрактно-неопределенным «светилом») фиксируется невозможностью автора определить длительность этого состояния: «не знаю, долог ли был сон...».

Размышления Тютчева о человеческом времени, желание уподобить человеческое время вечности, слив в нем одновременно прошлое и настоящее:

О, как тогда с земного круга

Душой к бессмертному летим!

Минувшее, как призрак друга,

Прижать к груди своей хотим, - (курсив мой. - Л. Ш.)

«Проблеск» [Тютчев 1965. 1: 9] 
ведут к трагическому финалу - пониманию невозможности изменить общий «порядок» времени. Уподобиться вечности нельзя, возможно лишь стремление к слиянию с ней в редчайшие мгновения, конец веры, конец мечты.

Но, ах, не нам его судили;

Мы в небе скоро устаем, -

И не дано ничтожной пыли

Дышать божественным огнем.

«Проблеск» [Тютчев 1965. 1: 9].

Человеку «не дано» длительно пребывать в неразличимом «покое» вечности.

В исследование сущности человеческого времени Тютчев был «погружен» на протяжении всей своей творческой жизни. В этом смысле наиболее характерно стихотворение «Я помню время золотое...»:

Я помню время золотое,

Я помню сердцу милый край.

День вечерел; мы были двое;

В тени, внизу, шумел Дунай.

И на холму, там, где, белея

Руина замка вдаль глядит,

Стояла ты, младая фея,

На мшистый опершись гранит.

Ногой младенческой касаясь

Обломков груды вековой;

И солнце медлило, прощаясь

С холмом, и замком, и тобой [Тютчев 1965. 1: 66].

Момент, всплывающий в памяти, оказывается промежуточным звеном в цепи Вечности. То, что за феей оказывается «вековая» руина замка, деталь не случайная, как не случайно то, что в окончательной

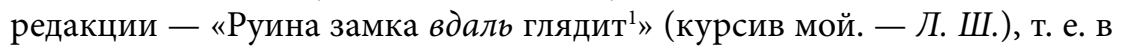

${ }^{1}$ См. две другие редакции: «Руина с крутизны глядит» и «Руина замка в 
пространственную бесконечность, остраняясь от земного, от «дола». Время в данном случае принимает пространственный образ в виде бесконечно уходящей линии. В «дол», замкнутый в пространственно-временном отношении, руина замка глядеть не может. Замена «дола» на «даль» оказалась весьма существенной, усиливая таким образом семантику всего стихотворения.

Но Тютчев хочет зафиксировать этот момент прошлого (как бы останавливает его) с тем, чтобы выявить, что в нем вечное, не подвластное времени (Такой неподвижной отметкой, относительно которой «течет» время, является в общем плане картины «руина замка»). Этим объясняется намеренное отсутствие движения, поскольку в данной ситуации (не отвлекающей внимания) возможно более рельефное противопоставление различных временных характеристик объектов картины, приближенных вплотную к зрителю: «Ногой младенческой касаясь обломков груда вековой» (курсив мой. - Л. Ш.). Это противопоставление времени феи и времени руины есть одновременно и их слияние в одном мгновении, которое здесь намеренно затягивается: «И солнце медлило, прощаясь / С холмом, и замком, и тобой...» (курсив мой. - Л. Ш.).

Приостановленное движение и время свидетельствуют о том, что в данном случае фея, как и руина, сопричастна вечности. Но явилось зло, закрывшее врата рая. Время, как бы наверстывая упущенное, вновь продолжило свой бег, тут же на глазах превращая в прошлое настоящее:

И ветер тихий мимолетом

Твоей одеждою играл

И с диких яблонь цвет за цветом

На плечи юные свевал.

Ты беззаботно вдаль глядела...

Край неба дымно гас в лучах,

День догорал; звучнее пела

Река в померкших берегах.

«Я помню время золотое» [Тютчев 1965. 1: 56].

Но для руины замка бег времени не страшен, она вдаль глядит (!) сквозь время. (За счет многоразового употребления перфектных форм 
создается образ быстро движущегося времени). Там, где фея «беззаботно вдаль глядела», «руина замка вдаль глядит» и по сей день, в тот момент, с которого ведется повествование о давно утраченном времени (и в этом смысле руина, сохраняя всю вещественную конкретность, символизирует для него вечность, в то время как образ феи является символом преходящего).

Здесь то же противопоставление времени и вечности, а если стихотворение содержит такое противопоставление, то вряд ли можно говорить о его «безмятежной настроенности» [Пигарев: 230]. Все стихотворение проникнуто не безмятежностью, а тоскливым ощущением быстротекучести времени и невосполнимости мгновений человеческой жизни. Длительность каждого момента человеческой жизни, как и длительность каждого явления в природе, воспринимаются Тютчевым всегда лишь по отношению к вечности (даже если в стихотворении о самой вечности не сказано ни слова).

Как неожиданно и ярко,

На влажной неба синеве,

Воздушная воздвиглась арка

В своем минутном торжестве!

Один конец в леса вонзила, Другим за облака ушла Она полнеба обхватила И в высоте изнемогла.

О, в этом радужном виденье Какая нега для очей!

Оно дано нам на мгновенье, Лови его - лови скорей!

Смотри - оно уж побледнело, Еще минута, две - и что ж? Ушло, как то уйдет всецело, Чем ты и дышишь и живешь «Как неожиданно и ярко...» [Тютчев 1965. 1: 204]. 
Bce, проходя через настоящее, не задерживаемся в нем более одного мгновения, постепенно погружаясь в небытие, в прошлое. Время выполняет роль некой грани, на которой чередуется бытие и ничто, настоящее и прошедшее. Отсюда своеобразная погоня за неуловимым и невозвратимым временем («еще минута, две - и что ж? Ушло...» «Как неожиданно и ярко...» [Тютчев 1965. 1: 204], желание остановить и «растянуть» его («О время, погоди!» стихотворение «Так в жизни есть мгновения ${ }^{1}$ [Тютчев 1965. 1: 160]. Человек напрасно мнит себя носителем времени:

Вот наша жизнь, - промолвила ты мне, -

Не светлый дым, блестящий при луне,

А эта тень, бегущая от дыма...

«Как дымней столп светлеет в вышине» [Тютчев 1965. 1: 114].

«Нет, непрочность человеческой жизни - единственная вещь на земле, которую никакие разглагольствования и никакое ораторское искусство никогда не в силах будут преувеличить» [Тютчев 1980. 2: 177-178]. Он подчинен конечному:

Все вместе - малые, большие

Утратив прежний образ свой,

Все - безразличны, как стихия, -

Сольются с бездной роковой!..

О нашей мысли обольщенье,

Ты, человеческое Я,

${ }^{1}$ Отсюда острый интерес Тютчева к отдельному моменту человеческой жизни и жизни природы. Он с особенной тщательностью рисует мгновенные явления природы (грозу, бурю), что можно объяснить стремлением запечатлеть характер этого момента времени, стремительность движения и изменения. Примерами тому служат стихотворения «Неохотно и несмело», «Как весел грохот летних бурь», «Весенняя гроза». На наш взгляд, именно в этих стихотворениях Тютчев приближается к импрессионистическому изображению природы. Поглощенность Тютчева настоящим сказывается в частом употреблении повелительных глагольных форм: «Смотри, как роща зеленеет». 
Не таково ль твое значенье, Не такова ль судьба твоя? «Смотри, как на речном просторе...» [Тютчев. 1965. 1: 130], —

а время бесконечно.

Человек несет в себе только настоящее. Будущее еще не существует, а прошлое (в собственном смысле) уже не существует. Прошлое теряет свою реальность, оно «царство теней», «мир давно распавшийся и сгинувший» [Тютчев 1980. 2: 88].

Реально только то, что есть, а «было» («Былое - было ли когда?») и «будет» («Кто смеет молвить: до свиданья Чрез бездну двух или трех дней?”) - «призраки»:

И наша жизнь стоит перед нами,

Как призрак ${ }^{1}$, на краю земли,

И с нашим веком и друзьями

Бледнеет в сумрачной дали.

«Бессонница» [Тютчев 1965. 1: 18].

Воспоминания о давних событиях или лицах передаются у Тютчева через отдаленность в пространстве:

Твой милый образ, незабвенный,

Он предо мной везде, всегда,

Недостижимый, неизменный,

Как ночью на небе звезда... (курсив мой. - Л. Ш.)

«Еще томлюсь тоской желаний» [Тютчев 1965. 1: 105].

Паскаль говорил: «Как страшно чувствовать, что течение времени уносит все, чем ты обладал». Почти та же мысль звучит в письмах и в стихотворениях Тютчева: «Какое отвратительное колдовство! Люди, воспоминание о которых здешние места оживили во мне до такой остроты, что мне стало казаться, будто я только что расстался с ними, предстали передо мной почти неузнаваемыми от разрушений времени... И мне кажется, что без меня ты больше во власти этого недуга,

1 В другом стихотворении: «О бедный призрак немощный и смутный забытого загадочного счастья». 
именуемого временем» (Из письма к Э. Ф. Тютчевой от 14 июля 1849 г.) [Тютчев 1980. 2: 60]. Этим можно объяснить усиленные попытки удержать воспоминания - «обломки былой жизни»: «Ты взял ее, но муку вспоминанья, Живую муку мне оставь по ней» [Тютчев 1965. 1: 197].

Тютчев мучительно решает проблему соотношения человеческого и вселенского времени (вечности). В лирике первого периода, как мы помним, предлагается подчас слияние времени личности с вечностью («Видение», «Как океан объемлет шар земной», «О чем ты воешь, ветр ночной»), которое всегда представляется как желаемое:

\author{
Дай вкусить уничтоженья \\ С миром дремлющим смешай! \\ «Тени сизые смесились» [Тютчев 1965. 1: 75].
}

В данных стихотворениях, казалось бы, проглядывает мифологическая структура: мифологическое слияние субъекта и объекта. Но оно осуществимо лишь при условии полного отсутствия чувства личности, понимания ее как безразличной части целого (в то время как для Тютчева личность представляет наивысшую ценность). В этом случае можно было бы утверждать, что человеческая жизнь, подобно природной, тяготеет к цикличности (возвращением к «родимому» хаосу). Но наряду с этим мотивом в лирике 1820-1830 гг. сосуществует другой: «тебе уж возрожденья нет», который впоследствии становится доминирующим.

В более поздней лирике совершенно немыслимо достижение и восстановление первородного мифологического единства субъекта и объекта (что является необходимым условием осуществления мифа) ${ }^{1}$.

Человеческое время необратимо («О сколько жизни было тут, невозвратимо пережитой» (курсив мой. - Л. Ш.) в стихотворении «Она сидела на полу»). Таков неизменный итог тютчевских раздумий. Тютчевым отвергается общеантичная излюбленная идея: если все возвращается на свои круги, то, что бы ни произошло, человек снова через какое-то время вернется к жизни и повторит то, что уже совершил. Тютчевский нигилизм приводит к полному отказу от идеи пантеистического бессмертия. Таким образом, можно сделать вывод, что миф y

\footnotetext{
${ }^{1}$ Античная гармония разрушена в стихотворении Тютчева «Певучесть есть в морских волнах».
} 
Тютчева кончается там, где начинается исследование времени личноcmu.

В лирике второго периода становится главным противопоставление времени природы времени личности, что приводит к разладу с природой, в результате которого отрицаются ее духовность и разумность: она не обладает памятью. Сомнения в существовании «Мировой души» приводят к появлению сниженных, «заземленных» картин вселенной за счет утраты прежней символической образности:

Святилище небес (т.е. хаос, курсив мой - Л. Ш.) «Видение» (1822),

сравним: И тот же мрак ... кругом (т.е. хаос, курсив мой. - Л. Ш.) «Брат, столько лет сопутствовавший мне» (1870).

Так как все явления рассматриваются Тютчевым под углом зрения вечности, то поэту свойственно занимать позицию вневременного вездесущего созерцателя (в особенности там, где изображается время в его фантастической длительности, к примеру, в ранее анализируемом нами стихотворении «Кончен пир, умолкли хоры...»). К тому же такая позиция, пространственная и временная («везде» и «всегда»), по Тютчеву, дает право превосходства и возвышает над изображаемой ситуацией. Наиболее характерно с этой точки зрения стихотворение «Два голоса» (1850). Вечному созерцателю как бы свойствен некий вневременный и всеобщий духовный опыт, предугадывающий неизбежность одних и тех же повторений в общем круговороте времени.

На позиции вечного созерцателя Тютчеву было свойственно становиться и в лирике первого периода. Но вечное созерцание там выражалось как своего рода желание. К примеру, в «Цицероне» (1830?) авторская позиция выражена желанием быть вечным (подобно богам) наблюдателем человеческой истории, ее катаклизмов:

Он их высоких зрелищ зритель,

Он в их совет допущен был -

И заживо, как небожитель,

Из чаши их бессмертье пил! (курсив мой. - Л. Ш.)

[Тютчев 1965. 1: 36]. 
Или, к примеру, стихотворение «Душа хотела 6 быть звездой» (1836?):

Душа хотела 6 быть звездой,

Но не тогда, как с неба полуночи

Сии светила, как живые очи,

Глядят на сонный мир земной, -

Но днем, когда сокрытые, как дымом

Палящих солнечных лучей,

Они, как божества, горят светлей

В эфире чистом и незримом. [Тютчев 1965. 1: 79].

Образ звезды, как уже упоминалось выше, связан у Тютчева с представлением о вечности. Значит, в данном случае желание быть звездой ассоциируется с желанием быть вечным. Но Тютчев оговаривает такой момент: «Душа хотела б быть звездой» не ночью, но днем, когда они как божества горят светлей (уже известная нам конструкция), не ярче, как ночью, а прозрачнее, освещенные снизу лучами солнца. Чем светлее, тем прозрачнее; чем прозрачнее, тем невидимее. Божество должно быть всевидящим, но невидимым. Стало быть, желание уподобиться дневной звезде равнозначно желанию быть божеством и вечно наблюдать не ночной, «сонный мир земной», неподвижный, мертвый в своих застывших очертаниях, а дневной, мир в движении и в его бесконечных превращениях, оставаясь в позиции созерцателя невидимого, «сокрытого как дымом... солнечных лучей» в «эфире незримом» для человеческого взгляда. И в то же время желание быть удаленным от «дольного чада», палимого солнцем (от зноя, что является зенитом жизни, близости смерти) - желание, которое сводится к стремлению преодолеть земное время.

Авторская позиция выражена желанием быть невидимым созерцателем вечного движения этого «дольного чада» и вечного изменения всех его явлений, т. е. быть на грани неподвижной вечности и изменчивого мира («палящие солнечные лучи» и есть та граница, разделяющее вечное и временное), в итоге на стыке времени и вечности.

Таким образом, если в стихотворениях до 1840-х гг. авторская позиция выражалась лишь желанием быть вечным созерцателем, быть вне времени, то в некоторых стихотворениях второго периода для Тютчева 
характерно утверждение авторской позиции как вневременной. И связано это с таким фактом, как ослабление пантеистических идей в лирике Тютчева: сознание ограниченности человеческой жизни во времени вылилось одновременно в утверждение неповторимости отдельной личности, стремление противостоять временному потоку.

Образы лирики природы Тютчева так или иначе находятся в зависимости от соотношения времени и вечности - мифологического принципа, в высшей степени связывающего стихотворения в одно смысловое целое. Через эту поистине космическую оппозицию (время - вечность), словно через многогранную призму, преломляется каждое стихотворение. Если человеческая жизнь ограничена во времени, имеет ли смысл человеческое познание («Фонтан», «Волна и дума»)? Именно из-за этой обреченности смерти человек не может постигнуть истинный смысл вечной природы. В связи с этой темой (развившейся в дальнейшем в тему человеческой беспомощности перед временем: см. стихотворение «Увы, что нашего незнанья...») параллельно возникает тема Рока («Из края в край», «Два голоса»), т. е. в художественно-философской поэтической системе Тютчева одно с другим оказывается тесно связанным.

Истинная символика каждого стихотворения в лирике природы Тютчева может быть понята лишь в соединении (посредством ассоциативно-семантической связи, о чем уже упоминалось выше) с другими стихотворениями. Каждое из них отражается в другом, подобно зеркалу в зеркале, образуя бесконечную смысловую перспективу, поскольку любое из этих стихотворений преломляется через центральную антитезу лирики природы Тютчева: время - вечность. Вся лирика природы Тютчева - это, образно выражаясь, желание бесконечно говорить о времени. 


\section{Список литературы \\ Источники}

Античная литература. Фрагменты. М.: Высшая партийная школа, 1940. 214 с.

Антология мировой философии в 4 т. М.: Мысль, 1974. Т. 1, ч. 1.686 с.

Брюсов В. Я. Ф. И. Тютчев. Критико-биографический очерк // Тютчев Ф. И. Полн. собр. соч.: в 3 кн. СПб.: Т-во А.Ф. Маркса, 1913. Т. 1. С. 5-37.

Веневитинов Д. В. Полн. собр. соч. М.; Л.: Академия, 1934. Т. 1.534 с.

Гете И. В. Избранные философские произведения. М.: Наука, 1964. 520 с.

Гуревич А. Я. Категории средневековой культуры. М.: Искусство, 1972. 318 с.

Даль В.И. Толковый словарь живого великорусского языка: в 4 т. СПб.: Диамант, 1996.

Зунделович Я. О. Этюды о лирике Тютчева. Самарканд, 1971. 167 с.

Пигарев К. В. Жизнь и творчество Ф. И. Тютчева. М.: Наука, 1962. 376 с.

Платон. Соч.: в 3 т.. М.: Мысль, 1974. Т. 3, ч. 1686 с.

Тынянов Ю.Н. Архаисты и новаторы. Л.: Прибой, 1929. 596 с.

Тютчев Ф. И. Лирика в 2 т. М.: Наука, 1965. Т. 1.446 с. Т. 2.451 с.

Тютчев Ф. И. Соч.: в 2 т. М.: Правда, 1980. Т. 2. 351 с.

Фукидид. История: в 2 т. М.: М. и С. Сабашниковы, 1915. Т. 1. 403 с.

Шевырев С. П. Стихотворения. Л.: Сов. писатель, 1939. 281 с.

Шеллинг Ф. В. Система трансцендентального идеализма. Л.: Соцэкгиз. Ленингр. отд-е, 1936. 455 с.

\section{Исследования}

Боровская И.О. Пространство во времени и время в пространстве в поэзии Ф. И. Тютчева // Филологические науки. Вопросы теории и практики. 2008. № 1 . С. 33-38.

Голованевский А. Л., Сычёва Е. Н. Семантическое поле «природа» в поэтической афористике Ф. И. Тютчева // Вестник Брянского государственного университета. 2015. № 1. С. 246-250.

Шакирова Л. Г. Тютчев и Шеллинг // Мир науки, культуры и образования. 2018. № 4 (71). C. 433-438. 


\section{References}

Borovskaia, I. O. "Prostranstvo vo vremeni i vremia v prostranstve $\mathrm{v}$ poezii F. I. Tiutcheva" ["Space in Time and Time in Space in F. I. Tyutchev's Poetry"]. Filologicheskie nauki. Voprosy teorii i praktiki, no. 1, 2008, pp. 33-38. (In Russ.)

Golovanevskii, A. L., Sycheva, E. N. "Semanticheskoe pole 'priroda' v poeticheskoi aforistike F. I. Tiutcheva" ["Semantic Field 'Nature' in F. I. Tyutchev's Poetic Aphoristics"]. Vestnik Brianskogo gosudarstvennogo universiteta, no. 1, 2015, pp. 246-250. (In Russ.)

Shakirova, L. G. "Tiutchev i Shelling" ["Tyutchev and Schelling"]. Mir nauki, kulttury i obrazovaniia, no. 4 (71), 2018, pp. 433-438. (In Russ.) 


\title{
Декабристы в эпическом отображении Л. Н. Толстого и Н. А. Некрасова
}

\author{
Исследование выполнено при финансовой поддержке РФФИ \\ в рамках научного проекта № 20-012-00102
}

\begin{abstract}
Аннотация: Статья посвящена изучению предпринятых Л. Н. Толстым в жанре романа и Н. А. Некрасовым в жанре поэмы наиболее масштабных в русской литературе XIX в. попыток создать эпическое произведение на материале движения декабристов и судеб его участников. Исследование основных этапов работы Толстого над неосуществленным замыслом «Декабристов», а Некрасова над поэмой «Дедушка» и циклом поэм «Русские женщины» позволяет сделать вывод о том, что работа над эпическими произведениями в прозе и в стихах привела Толстого и Некрасова к результатам крайне несхожим. Психологически углубленные толстовские зарисовки и горячий, а местами мелодраматический пафос поэм Некрасова образовали во многом контрастные художественные миры. Нравственный поиск Толстого в несостоявшемся романе предполагает разрешение общественных противоречий в области своеобразной «религии чувства» и вызывает грандиозный «побочный эффект» создание романа-эпопеи «Война и мир». Поэмы Некрасова вслед за публицистикой А. И. Герцена закладывают основы декабристского мифа и культа декабристов как мучеников революционной веры. Выдвигается гипотеза о том, что неудача Толстого в работе над романом о декабристах и малая художественная состоятельность «декабристских» поэм Некрасова объясняются отсутствием в историческом материале основы для подлинно эпического творчества.
\end{abstract}

Ключевье слова: Л. Н. Толстой, Н. А. Некрасов, С. Г. Волконский, декабристы, «Война и мир», «Дедушка», «Русские женщины», эпическое.

Информация об авторе: Александр Вадимович Гулин, доктор филологических наук, ведущий научный сотрудник, Институт мировой литературы им. А. М. Горького Российской академии наук, ул. Поварская, д. 25 a, 121069 г. Москва, Россия.

E-mail: gulinimli@yandex.ru

Дата поступления статьи в редакиию: 11.02 .2021

Дата одобрения статьи рецензентами: 18.03 .2021

Дата публикации статьи: 28.06.2021

Для иитирования: Гулин А. В. Декабристы в эпическом отображении Л. Н. Толстого и Н. А. Некрасова // Два века русской классики. 2021. Т. 3, № 2. С. 96-119. https://doi.org/10.22455/2686-7494-2021-3-2-96-119 


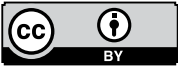

This is an open access article distributed under the Creative Commons Attribution

4.0 International (CC BY 4.0)
Dva veka russkoi klassiki,

vol. 3, no. 2, 2021, pp. 96-119. ISSN 2686-7494

Two centuries of the Russian classics,

vol. 3, no. 2, 2021, pp. 96-119. ISSN 2686-7494

Research Article

(c) 2021. Alexander V. Gulin

A. M. Gorky Institute of World Literature of the Russian Academy of Sciences

Moscow, Russia

\section{The Decembrists in the Epic Representation of L. N. Tolstoy and N. A. Nekrasov}

Acknowledgments: The reported study was funded by Russian Foundation for Basic Research (RFBR), project number 20-012-00102.

Abstract: The article considers the most ambitious attempts in Russian literature of the $19^{\text {th }}$ century to create an epic work on the material of the Decembrist movement and the fate of its participants made by L. N. Tolstoy in the genre of novel and by N. A. Nekrasov in the genre of poem. The study of main stages of Tolstoy's work on the unfulfilled plan of the Decembrists and Nekrasov's work on the poem Grandfather and the cycle of poems "Russian Women" allows to conclude that Tolstoy and Nekrasov, creating their epic works in prose and verse, came to extremely dissimilar results. Tolstoy's psychologically deep sketches and hot and sometimes melodramatic pathos of Nekrasov's poems formed in many ways contrasting artistic worlds. Tolstoy's moral search in the failed novel presupposes the resolution of social contradictions in the field of a kind of "religion of feeling" and causes a grandiose "side effect" - the creation of the epic novel War and Peace. Nekrasov's poems, following the journalism of A. I. Herzen, laid the foundations of the Decembrist myth and the cult of the Decembrists as martyrs of the revolutionary faith. The hypothesis is put forward that Tolstoy's failure to work on a novel about the Decembrists and the low artistic viability of Nekrasov's Decembrist poems are explained by the lack of a basis for truly epic creativity in the historical material.

Keywords: L. N. Tolstoy, N. A. Nekrasov, S. G. Volkonsky, the Decembrists, War and Peace, Grandfather, Russian Women, epic.

Information about the author: Alexander V. Gulin, DSc in Philology, Leading Research Fellow, A. M. Gorky institute of World Literature of the Russian Academy of Sciences, Povarskaya 25 a, 121069, Moscow, Russia

E-mail: gulinimli@yandex.ru

Received: February 11, 2021

Approved after reviewing: March 13, 2021

Published: June 28, 2021

For citation: Gulin, A. V. “The Decembrists in the Epic Representation of L. N. Tolstoy and N. A. Nekrasov." Dva veka russkoi klassiki, vol. 3, no. 2, 2021, pp. 96-119. (In Russ.) https://doi.org/10.22455/2686-7494-2021-3-2-96-119 
Л. Н. Толстого и Н. А. Некрасова в 1850-е гг. - первое время их знакомства - соединяли многообразные творческие, деловые и жизненные связи. Именно Некрасов и его журнал «Современник» (впрочем, избранные для дебюта самим молодым писателем) открыли Толстому дорогу в литературу. Роль Некрасова в распознавании дарования Толстого, в том, что его творческий путь с первых шагов сложился так, а не иначе, что издательская судьба ранних произведений писателя оказалась исключительно благоприятной, общеизвестна. С исчезновением прямых творческих контактов и нарастанием идейных противоречий на протяжении 1860-1870-х гг. отношения Некрасова и Толстого ограничились редкой деловой перепиской. Тем показательнее, при всем расхождении художественных и человеческих судеб, выглядят в это время творческие сближения старшего и младшего литераторов. Наиболее очевидным здесь, конечно, является пристальный интерес одного и другого к русскому крестьянскому миру. Но по-своему не менее значительной выглядит и многолетняя увлеченность обоих художников темой декабристов.

Декабризм как идейное, духовное, психологическое, сословное явление, как предмет и содержание творчества со времени его появления и на протяжении всего XIX столетия сохранял более или менее постоянное значение для русской литературы. Декабристская проблематика прямо, а чаще глубинно присутствует в творчестве большинства русских писателей-классиков - прежде всего, как составляющая огромной, по сути эсхатологической темы революции и традиции в национальной жизни. Но только Некрасову и Толстому, одному - в форме поэмы, другому - в форме романа, принадлежат в большой русской литературе попытки создать эпическое произведение о декабристах. Существуют в этих попытках - по видимости, параллельных, как будет видно из дальнейшего, - и вполне очевидные пересечения. 
Непосредственный интерес к декабристам и декабризму оживился в русском обществе одновременно с коронационным манифестом 1856 г., одна из статей которого объявляла о помиловании сибирских изгнанников. Вскоре началось возвращение тех из них, кто остался жив, в центральную Россию. К тому же времени относился и первый замысел произведения Толстого о декабристах. «В 1856 году, - говорил писатель, - я начал писать повесть с известным направлением, героем которой должен был быть декабрист, возвращающийся с семейством в Россию» [Толстой 1928-1958. 13: 53]. Возможно, здесь имеется в виду только замысел произведения, потому что в начале 1861 г., находясь за границей, Толстой сообщал А. И. Герцену: «Я затеял месяца четыре тому назад роман, героем которого должен быть возвращающийся декабрист. Я хотел поговорить с вами об этом, да так и не успел. - Декабрист мой должен быть энтузиаст, мистик, христианин, возвращающийся в 56 году в Россию с женою, сыном и дочерью и примеряющий свой строгий и несколько идеальный взгляд к новой России. Скажите, пожалуйста, что вы думаете о приличии и своевременности такого сюжета. Тургеневу, кот<орому> я читал начало, понравились первые главы» [Толстой 1928-1958. 60: 373]. Работа над романом продолжалась и в конце 1862 г., что отметила вскоре после свадьбы молодая жена Толстого Софья Андреевна. В результате появились три черновые главы произведения о современности, в которых действовал только что вернувшийся из Сибири старик-декабрист с вымышленным именем Петр Лабазов.

$\mathrm{C}$ «декабристским» сюжетом оказался теснейшим образом связан замысел романа-эпопеи «Война и мир». Толстой, по его широко известному признанию, совершил как бы «возвратный» путь от 1856 г. к началу жизни своего героя: «Итак, от 1856 года возвратившись к 1805 году, я с этого времени намерен провести уже не одного, а многих моих героинь и героев через исторические события 1805, 1807, 1812, 1825 и 1856 года. Развязки отношений этих лиц я не предвижу ни в одной из этих эпох» [Толстой 1928-1958. 13: 53]. Но только в эпилоге «Войны и мира» тема декабристов снова заявила о себе со всей очевидностью. Писатель не считал ее вполне освоенной, в 1870-х гг. он снова вернулся к «декабристскому» замыслу. Но особенно увлекла его эта работа после окончания в 1877 г. романа «Анна Каренина», когда в 1878-1879 гг. было написано подавляющее большинство из пятнадцати сохранившихся «начал» «декабристского» романа. По существу, это был новый срав- 
нительно с «лабазовским» романом 1860-х гг. творческий замысел. Он также не получил дальнейшего развития. Однако в 1884 г., по просьбе издателей сборника «XXV лет» Общества для пособия нуждающимся литераторам и ученым, Толстой отдал в печать под общим названием «Декабристы» три давние главы и два фрагмента конца 1870-х гг., тем самым объединив их в одно целое. Возможно, этим подчеркивалось, что работа над «Декабристами» была своеобразным, хотя и прерывистым фоном для создания двух великих шедевров русской литературы: «Войны и мира» и «Анны Карениной».

Поэмы Некрасова о декабристах создавались в гораздо более короткий период. Первая из них - «Дедушка» - была написана и сразу же опубликована в 1870 г., а две части единого цикла «Русские женщины» появились соответственно - «Княгиня Трубецкая» в 1871 г. (первая публикация - 1872 г.), и «Княгиня М. Н. Волконская» в 1872 г. (первая публикация - 1873 г.). Поэт предполагал, что завершением цикла станет третья поэма, посвященная А. Г. Муравьевой, но она так и осталась в замыслах.

И Толстой, и Некрасов, подступая к декабристской теме, стремились к возможно большей фактической обоснованности своих произведений. Толстой за два десятилетия, в течение которых продолжались его попытки писать роман о дворянских революционерах, лично познакомился с несколькими из них. Первым и, вероятно, самым счастливым знакомством было несколько месяцев, проведенных писателем в Монтрё и Веве на берегу Женевского озера весной и летом 1857 г. в одной дружеской компании с братом лицейского товарища Пушкина М. И. Пущиным (которого, впрочем, можно считать декабристом только с известными оговорками). Разумеется, Толстого связывали с декабристами не только творческие интересы, но и простая сословная принадлежность к одному достаточно узкому кругу и родственные связи с некоторыми из них. Так, в конце 1860 г. Толстой встретился во Флоренции со своим троюродным дядей С. Г. Волконским и его женой Марией Николаевной (урожденной Раевской). В круг лично ему известных декабристов, к которым писатель много позднее обращался именно в поиске необходимых материалов, вошли М. И. МуравьевАпостол, П. Н. Свистунов, А. П. Беляев, Д. И. Завалишин. Печатные и рукописные источники о людях 14 декабря также изучались Толстым, особенно в 1870-е гг., с предельной основательностью. 
Некрасов, не имея столь широких связей среди декабристов, тоже собирал сведения о них в 1860-1870-е гг. Достаточно сказать, что никому не известные в ту пору рукописные «Записки» М. Н. Волконской (впервые опубликованы только в 1904 г.) в течение нескольких вечеров ему читал вслух, тут же переводя с французского, который поэт знал недостаточно, сын декабриста и хороший знакомый Некрасова М. С. Волконский.

Работа над эпическими произведениями о декабристах в прозе и в стихах, как того и следовало ожидать, привела Толстого и Некрасова к результатам крайне несхожим. Психологически углубленные толстовские зарисовки и горячий, а местами и мелодраматический пафос поэм Некрасова образовали во многом контрастные художественные миры. То же самое можно сказать и о глубинных идейных установках каждого из художников: нравственный поиск Толстого, предполагающий разрешение общественных противоречий исключительно в области своеобразной «религии чувства», и вполне радикальный некрасовский социальный протест в сочетании с демократическим «прогрессизмом» поэта создают впечатление ни в чем не сходящихся крайних позиций. Тем не менее одно и другое существует в пределах единого принципа, некоего преемственного по отношению к декабризму своевольного жизненного идеала. Намерение искать духовную и нравственную опору для современного мира именно в декабристах само по себе выглядело у каждого из художников весьма красноречивым.

В 1858 г., разочарованный духом преобразований своего времени, Толстой написал В. П. Боткину: «Политическая жизнь вдруг неожиданно обхватила собой всех. Как бы мало кто ни был приготовлен к этой жизни, всякий чувствует необходимость деятельности. И что говорят и что делают, страшно и гадко становится. <...> А людей, которые бы просто силой добра притягивали бы к себе и примиряли людей в добре, таких нету» [Толстой 1928-1958. 60: 245, 247]. Первый «декабристский» роман задумывался Толстым именно в русле этого высказывания. Описание русской современности выглядело здесь жёлчно-сатирическим: «Это было недавно, в царствование Александра II, в наше время - время цивилизации, прогресса, вопросов, возрождения России и т. д., и т. д. В то время, когда победоносное русское войско возвращалось из сданного неприятелю Севастополя, когда вся Россия торжествовала уничтожение черноморского флота, и белокаменная Москва 
встречала и поздравляла с этим счастливым событием остатки экипажей этого флота, подносила им добрую русскую чарку водки и, по доброму русскому обычаю, хлеб-соль и кланялась в ноги <..>, явились вопросы кадетских корпусов, университетов, цензуры, изустного судопроизводства, финансовый, банковый, полицейский, эманципационный и много других. Все старались отыскивать еще новые вопросы, все пытались разрешать их, писали, читали, говорили проекты, всё хотели исправить, уничтожить, переменить, и все россияне, как один человек, находились в неописанном восторге» [Толстой 2000. 4: 179-180].

Движение писателя к «Войне и миру» совершалось как бы от противного, в поиске исторической точки опоры: «Русский мир эпохи первой Отечественной войны представлял собой, по мысли Толстого, необходимую нравственную альтернативу отравленной духом разлада современности. Этот ясный устойчивый мир, хорошо понимал писатель, таил в себе вечные духовные ориентиры. Повинуясь верному историческому чутью, Толстой избрал в 1860-е годы предметом для своего творчества единственную в XIX веке эпоху неомраченного, основанного на действительной нравственной связи сплочения всех сословий, всех элементов общества» [Гулин 2018: 11-12]. Тем показательнее, что совершенно в духе современных ему идейных и нравственных блужданий Толстой связал русскую победу над Наполеоновским нашествием и зарождение декабризма. Нам уже приходилось неоднократно говорить об этом устойчивом представлении двух минувших столетий: «Наши современники часто думают <...>, что восстание декабристов было прямо подготовлено событиями 1812 года. Долгое время дело представлялось так, будто спасители Отечества от нашествия извне хотели теперь спасти его изнутри. Но стоит лишь различить в тумане позднейших наслоений живые ценности той великой войны, как декабристы предстанут едва ли не продолжателями дела Наполеона на русской почве. Да, многие из них были участниками только что отгремевшей священной брани. Но это они же (и с этим тоже нельзя поспорить!) покусились несколько лет спустя на те самые святыни, что отстояли, сознательно или нет, в прошедшие годы» [Гулин 2003: 16-17].

Возможно, Петр Лабазов - центральный персонаж начатого, но так и не законченного «декабристского» романа начала 1860-х гг. как раз и виделся Толстому героем, примиряющим людей в добре среди наступившего общественного хаоса. Таким же персонажем отчасти оказался 
и Пьер Безухов на страницах эпилога «Войны и мира». Безухов - очень странный декабрист, не заговорщик, не политик. Он человек, всем без исключения желающий добра, каким он его себе представляет, каким он понял его в 1812 г. «Ведь я не говорю, - утверждал он, — что мы должны противудействовать тому-то и тому-то. Мы можем ошибаться. А я говорю: возьмемтесь рука с рукою те, которые любят добро, и пусть будет одно знамя - деятельная добродетель» [Толстой 1928-1958. 12: 291].

Между тем именно «каратаевские» открытия, сделанные Безуховым на исходе 1812 г., неумолимо влекли героя к попытке «освободить» общество от любых «цивилизованных» начал. В эпилоге «Войны и мира» разгорался спор о современности между Пьером и его новым родственником Николаем Ростовым. И далеко не Ростов, готовый исполнить согласно присяге любой приказ нелюбимого Безуховым Аракчеева, выступал зачинщиком этого конфликта. Это Пьер, убежденный, что без него «все распадается», говорил и действовал как обладатель последней истины. Он мечтал, что «люди добра» все вместе предотвратят новую пугачевщину. Однако подобный рецепт исцеления «по-безуховски» не обещал подлинной России ни мира, ни согласия. Слишком своевольным, гордым, расплывчатым было это добро, в одиночку найденное героем. Толстовская религия безгрешного человечества (сквозная для Толстого формула - «Нет в мире виноватых») приносила совсем не те плоды, о которых мечталось.

Прообразом декабриста Лабазова у Толстого и дедушки из одноименной поэмы Некрасова (или одним из таких прообразов) можно вполне определенно считать Сергея Григорьевича Волконского единственного действующего генерала среди декабристов на момент разгрома дворянских революционеров. И в «лабазовских» главах «декабристского» романа Толстого, и в поэме Некрасова действие происходит в период возвращения героя из Сибири. И там и здесь в облике декабриста подчеркиваются поражавшие современников чуть ли не библейские черты, которые отличали старика Волконского. Уже в начале XX в. Толстой вспоминал о своей встрече с ним в 1860 г.: «Его наружность, - с длинными седыми волосами была совсем как у ветхозаветного пророка... Это был удивительный старик, цвет петербургской аристократии, родовитой и придворной» [Гольденвейзер: 141].

Разумеется, у Толстого никогда не заходила речь о святости декабристов. Зато в поэмах Некрасова «мученики свободы» нередко выгля- 
дели именно как святые новой революционной веры. Некрасов, безусловно, вполне разделял мысли на сей счет главного основоположника декабристского мифа в русском общественном сознании и создателя своеобразной «религии декабризма» А. И. Герцена. Характерными в этом смысле выглядят слова, прозвучавшие в короткой герценовской заметке «Князь Сергей Григорьевич Волконский» на смерть декабриста в 1865 г.:

Сходят в могилу великие страдальцы николаевского времени, наши отцы в духе и свободе, герои первого пробуждения России, участники великой войны 1812 и великого протеста $1825 \ldots$

Пусто... мелко становится без них...

Князь Сергей Григорьевич Волконский скончался 28 ноября (10 декабря).

С гордостью, с умилением вспоминаем мы нашу встречу с старцем в 1861 году. Говоря об ней в “Колоколе” < ..>, мы боялись назвать старца.

«...Старик, величавый старик, лет восьмидесяти, с длинной серебряной бородой и белыми волосами, падавшими до плеч, рассказывал мне о тех временах, о своих, о Пестеле, о казематах, о каторге, куда он пошел молодым, блестящим и откуда только что воротился седой, старый, еще более блестящий, но уж иным светом.

Я слушал, слушал его - и когда он кончил, хотел у него просить напутственного благословения в жизнь - забывая, что она уже прошла... и не одна она... < ...> Пограничные споры двух поколений, поддерживающие их память, надоедят - и из-за них всплывут тени старцев-хранителей и, через кладбище сыновей своих, призовут внуков на дело и укажут им путь».

Удивительный кряж людей... Откуда XVIII век брал творческую силу на создание гигантов везде, во всем, от Ниагары и Амазонской реки до Волги и Дона?.. Что за бойцы, что за характеры, что за люди! [Герцен 19: 16-17].

Некрасовское изображение дедушки, его первой встречи с родными после сибирского изгнания определенно имело одним из своих источников эту неподцензурную заметку Герцена и оказалось выдержано в той же восторженно-религиозной тональности:

Все, уж давно поджидая, Встретили старого вдруг... 
Благословил он, рыдая,

Дом, и семейство, и слуг,

Пыль отряхнул у порога,

С шеи торжественно снял

Образ распятого бога

И, покрестившись, сказал:

- Днесь я со всем примирился,

Что потерпел на веку!..-

Сын пред отцом преклонился,

Ноги омыл старику;

Белые кудри чесала

Дедушке Сашина мать,

Гладила, их, целовала,

Сашу звала целовать [Некрасов 4: 111-112].

«Декабристы, - резюмирует Е. Б. Васильева свой комплексный анализ изданий А. И. Герцена и Н. П. Огарева, - идентифицировались как “святые мученики”, “святые отцы”, “мученики 14 декабря”, “великие мученики”. Редакторы проводили прямое отождествление декабристов с Христом, так как декабристы вышли на Сенатскую площадь чтобы “...очистить детей рожденных в среде палачества и раболепия”. Возвращение же декабристов из ссылки уподоблялось воскрешению, дающему России еще один шанс нового, справедливого будущего...» [Васильева: 72].

У Некрасова в поэме тоже следует целый ряд определений, по видимости, растворенных в тексте (в том числе, несомненно, из цензурных соображений), но все-таки образующих представление о дедушке как идеальном герое, праведнике «новой веры»:

Дедушка древен годами, Но еще бодр и красив,

Строен, высокого роста,

Но как младенец глядит,

Как-то апостольски-просто,

Ровно всегда говорит... [Некрасов 4: 112]. 
В том же духе выдержано и одно из наиболее выразительных мест в поэме:

Пел он о славном походе

И о великой борьбе;

Пел о свободном народе

И о народе-рабе;

Пел о пустынях безлюдных

И о железных цепях;

Пел о красавицах чудных

С ангельской лаской в очах;

Пел он об их увяданье

В дикой, далекой глуши

И о чудесном влиянье

Любящей женской души...

О Трубецкой и Волконской

Дедушка пел - и вздыхал,

Пел - и тоской вавилонской

Келью свою оглашал... [Некрасов 4: 120].

Свое продолжение эти строки получат в обеих поэмах цикла «Русские женщины». Но с особенной силой представление о святости декабристов прозвучит в прямой речи главной героини второй поэмы М. Н. Волконской:

Напрасно чернила его клевета,

Он был безупречней, чем прежде,

И я полюбила его, как Христа...

В своей арестантской одежде

Теперь он бессменно стоит предо мной,

Величием кротким сияя.

Терновый венец над его головой,

Во взоре - любовь неземная... [Некрасов 4: 161].

Продолжением сказанному у Некрасова служил эпизод уже действительной встречи Волконской с мужем, почерпнутый поэтом из сообщенных ему изустно записок княгини, правда, перенесенный для 
поэтического эффекта непосредственно в рудник, под землю, где работали в первые годы своего заключения некоторые декабристы. Здесь, между прочим, появились и допускающие двоякое (в случае с «передовой общественностью» можно не сомневаться, какое) толкование строки о «мстительном палаче»:

Да, цепи! Палач не забыл никого

(О, мстительный трус и мучитель!), -

Но кроток он был, как избравший его

Орудьем своим искупитель.

$\ldots$

Я только теперь, в руднике роковом,

Услышав ужасные звуки,

Увидев оковы на муже моем,

Вполне поняла его муки,

И силу его... и готовность страдать!

Невольно пред ним я склонила

Колени, - и прежде чем мужа обнять,

Оковы к губам приложила!.. [Некрасов 4: 183-184].

Вскоре после публикации поэмы Ф. М. Достоевский на страницах «Дневника писателя» за 1873 г. поставил эту сцену (жена целует оковы своего мужа прежде, чем поцеловать самого мужа) под сомнение как психологически неточную. Писатель говорил о «мундирности» поэмы, подразумевая в этом случае некий обязательный в «рукопожатном» обществе того времени либерально-фрондерский «мундир». «Я читал две последние поэмы Некрасова - решительно этот почтенный поэт ходит теперь в мундире. А ведь даже и в этих поэмах есть несколько хорошего и намекает на прежний талант г-на Некрасова. Но что делать: мундирный сюжет, мундирность приема, мысли, слога, натуральности... да, мундирность даже самой натуральности. Знает ли, например, маститый поэт наш, что никакая женщина, даже преисполненная первейшими гражданскими чувствами, приявшая, чтобы встретиться с несчастным мужем, столько трудов, проехавшая шесть тысяч верст в телеге $\langle\ldots>$ - знаете ли вы, поэт, что эта женщина ни за что не поцелует сначала цепей любимого человека, а поцелует непременно сначала его самого, а потом уже его цепи, если уж так сильно и внезапно 
пробудится в ней великодушный порыв гражданского чувства, и так сделает всякая женщина решительно» [Достоевский 21: 73]. Тем самым Достоевский невольно вступил в полемику не только с автором поэмы, но и с ее источником, дотошно пересказанным у Некрасова. Однако создатель «Записок из Мертвого дома» все-таки лучше многих понимал, о чем он говорит. Всегда высоко почитаемый Достоевским подвиг жен декабристов, нередко их действительно христианское страдание за своих мужей представали в поэме как прямое соучастие в деле дворянских революционеров.

Из приведенных примеров хорошо заметно различие подходов к теме декабристов Толстого и Некрасова. Тем не менее это не исключает наличия некой глубинной точки соприкосновения двух художников, которую особенно ярко демонстрирует творческий сюжет с «декабристским» эпилогом «Войны и мира» и поэмой «Дедушка». Печатание романа-эпопеи было завершено Толстым осенью 1869 г. Некрасовская поэма написана в следующем 1870 г. Даже учитывая, что важнейшим импульсом для ее создания Некрасову служили воспоминания и размышления о Волконском А. И. Герцена, можно почти уверенно говорить и о том, что эпилог «Войны и мира» тоже был внимательно прочитан поэтом.

На эти мысли наводит заметная смысловая перекличка двух произведений. Скажем, приехавший из Петербурга Пьер Безухов говорит в разговоре с Николаем Ростовым: «Положение в Петербурге вот какое: государь ни во что не входит. Он весь предан этому мистицизму (мистицизма Пьер никому не прощал теперь). Он ищет только спокойствия, и спокойствие ему могут дать только те люди sans foi ni loi (без совести и чести - $ф р$.$) , которые рубят и душат всё сплеча: Магницкий,$ Аракчеев и tutti quanti (тому подобные $-u m$.) $<\ldots>-$ Ну, и все гибнет. В судах воровство, в армии одна палка: шагистика, поселения, - мучат народ, просвещение душат. Что молодо, честно, то губят! Все видят, что это не может так идти» [Толстой 1928-1958. 12: 182]. А дедушка у Некрасова вдохновенно рисует малолетнему внуку такую картину из прошлых дней:

Впрочем, не то еще было!

И не одни господа,

Сок из народа давила 
Подлых подьячих орда.

Что ни чиновник - стяжатель

С целью добычи в поход

Вышел... а кто неприятель?

Войско, казна и народ!

Всем доставалось исправно.

Стачка, порука кругом:

Смелые грабили явно,

Трусы тащили тайком.

Непроницаемой ночи

Мрак над страною висел...

Видел - имеющий очи

И за отчизну болел [Некрасов 4: 117].

Но куда важнее в поэме Некрасова собственно несущий поэтический прием: дедушка-революционер, не сообщая внуку причину своего многолетнего страдальческого отсутствия, исподволь, шаг за шагом готовит мальчика к тому, чтобы открыть ему свою тайну - и одновременно к чему-то великому и светлому, очевидно, к подвигу на благо народа и страны:

Время проходит. Исправно

Учится мальчик всему -

Знает историю славно

(Лет уже десять ему),

Бойко на карте покажет

И Петербург, и Читу,

Лучше большого расскажет

Многое в русском быту.

Глупых и злых ненавидит,

Бедным желает добра,

Помнит, что слышит и видит...

Дед примечает: пора!

Сам же он часто хворает,

Стал ему нужен костыль...

Скоро уж, скоро узнает

Саша печальную быль... [Некрасов 4: 122]. 
Вероятнее всего, поэт прямо развивал здесь мечту Герцена о том, что «тени старцев-хранителей» «призовут внуков на дело и укажут им путь». Но даже в том случае, если Некрасов писал свою поэму, не оглядываясь вольно или невольно на роман-эпопею Толстого, оба художника видели будущее России примерно в одном ключе. Сентиментальный идеализм Толстого и революционно-демократический энтузиазм Некрасова приводили к похожим последствиям. Своеобразной мерой правоты «декабриста» Пьера Безухова и «охранителя» Николая Ростова в «Войне и мире» стало причудливое отражение их спора во внутреннем мире юного Николеньки Болконского. Странный сон, увиденный мальчиком, завершал художественный рассказ эпилога и завершал собственно роман. Дядя Пьер и он сам в касках, наподобие тех, что носили герои античности (Николенька увлекался Плутархом), войско, которое они ведут за собой, дядя Николай Ильич, грозно ставший у них на пути, князь Андрей - умерший отец, который внезапно слился с образом Пьера и заменил его собой. Проснувшийся Николенька грезил о подвигах, о славе. Но больше всего - о чем-то возвышенном и прекрасном, что сделает он сам во имя всех людей: “"Я знаю, они хотят, чтобы я учился. И я буду учиться. Но когда-нибудь я перестану; и тогда я сделаю. Я только об одном прошу Бога: чтобы было со мною то, что было с людьми Плутарха, и я сделаю то же. Я сделаю лучше. Все узнают, все полюбят меня, все восхитятся мною". И вдруг Николенька почувствовал рыдания, захватившие его грудь, и заплакал» [Толстой 1928-1958. 12: 294].

В этих мечтах о благе человечества Николенька был заодно с Безуховым, так же, как Саша у Некрасова имел перед собой пример дедушки. Но сон Николеньки, но благородные устремления Саши никому не предвещали мира, потому что «естественное» добро Безухова, потому что благородная борьба дедушки «за все хорошее против всего плохого», устремляясь в подлинную жизнь со страниц художественной реальности, обещали этой жизни поистине великие потрясения. Слишком своевольным оказывалось и это пережитое двумя мальчиками разных поколений «не названное, но высокое».

В 1872 г. старший современник Толстого и Некрасова П. А. Вяземский, обращаясь к своему многолетнему корреспонденту Петру Ивановичу Бартеневу, написал по поводу недавно подготовленного Бартеневым сборника исторических материалов «XIX век»: «К чему, например, 
дали Вы так много места декабристам в сборнике XIX века? Неужели значение их в историческом отношении так крупно, что оно может обозначать эпоху и что с них как будто следует начинать новое летоисчисление? В беспристрастной оценке этого дела нельзя не прийти к заключению, что умыслы их были преступны и безумны не только противу правительства, но и противу России, которая не устояла бы или, по крайней мере, надолго была бы потрясена, если бы покушение их увенчалось успехом. Оно залило бы Россию кровью, и эти передовые люди утоплены были бы в этой крови другими лицами, передовейшими. Да и самые передовые лица были ли в самом деле крупные исторические личности? Ни в одном из них не было государственных залогов и зачатков. Они были политические Белинские. <...> Мысль, что Россия утратила в них много обещавшую жатву, - мысль, по мне, неверная» [Летописи: 495-496, 497].

Пожалуй, Вяземский ошибался только в одном - в готовности преобладающего большинства своих образованных современников действительно вести новое летоисчисление «по декабристскому календарю». В остальном же, увы, слишком многое подтверждало его правоту. Скажем, создававшиеся С. Г. Волконским на старости лет «Записки» (они завершаются рассказом о начале следствия по делу декабристов) представляют образ мемуариста, весьма далекий от тех «гигантов», которые грезились мечтательному Герцену. И дело здесь даже не в том, что подобно всем вообще декабристам Волконский не испытывал и малейших угрызений совести по поводу погубленных революционерами подчиненных им «нижних чинов», а в чрезвычайной простоте, односложности - если использовать определение К. Н. Леонтьева, «высоких помыслов» рассказчика.

«Как я уже упомянул, - пишет Волконский - во время первого моего пребывания в Киеве я вошел в кружок людей мыслящих, что дела их не должны ограничиваться шарканьем и пустопорожней жизнью петербургских гостиных и шагистикой военной гарнизонной жизни, а что жизнь и дела их должны быть посвящены пользе родины и гражданским преобразованиям, имеющим целью поставить Россию на уровень гражданского быта, введенного в Европе в тех государствах, где начало было не власть деспотов, но права человека и народов, и к этому времени надо приписать первые общие попытки общественного мнения к уничтожению крепостного права» [Волконский: 407]. Престарелый 
декабрист будет вполне искренне приписывать усилиям людей 1825 г. состоявшееся много лет спустя по воле правительства освобождение крепостных. Подобно еще нескольким из вернувшихся в Россию изгнанников, он будет также прекрасно улавливать спрос на революционные настроения и постарается вполне ему соответствовать: «Прежде, нежели взяться за нить действия по тайному обществу, еще отклонюсь к частной личности; полагаю обязанностью оспаривать убеждение, тогда уже вкравшееся между членами общества и как-то доныне существующее, что Павел Иванович Пестель действовал из видов тщеславия и искал при удаче захватить власть, а не имел целью чистой общей выгоды, - мнение, обидное памяти того, кто принес свою жизнь в жертву общему делу» [Волконский: 417]. Продолжая свой рассказ о Пестеле, который одно время собирался выйти из движения и отправиться за границу, Волконский напишет: «Только мои увещания, голос истинного убеждения моего заставили Пестеля отказаться от своего намерения; но как суждено было нашему обществу потерпеть неудачу, то теперь я и не рад, что отклонил его от поездки в чужие края. Он был бы жив и был бы в глазах Европы иным историком нашему делу, чем Николай Тургенев...» [Волконский: 418]. Как видим, забота о международном резонансе, о том, как посмотрит на происходящее в России «просвещенное» мировое сообщество, тоже не была чуждой мемуаристу.

Впрочем, есть в мемуарах Волконского эпизод, который один стоит едва ли не всех его записок. Вспоминая проходивший осенью 1823 г. смотр государем Александром Павловичем расположенной на Украине Второй армии, Волконский рассказал, каким образом император дал ему понять, что планы заговорщиков не являются для него тайной. По словам мемуариста, в ту пору командира пехотной бригады (два полка), царь подозвал его к себе и похвалил следующим образом: «Я очень доволен Вашей бригадой; Азовский полк - из лучших полков моей армии, Днепровский немного отстает - но видны и в нем следы ваших трудов. И по-моему, гораздо для вас выгоднее будет продолжать оные, а не заниматься управлением моей Империи, в чем вы, извините меня, и толку не имеете» [Волконский: 434]. Одной-единственной фразой государь и похвалил своего бригадного командира, и напомнил ему о служении царю как единственном источнике дворянских привилегий, и предостерег от самозваных, по сути - безответственных, дилетантских, целей зреющего заговора. 
Замыслы эпического произведения о декабристах ни у Толстого, ни у Некрасова в полной мере не состоялись. На то существовал целый ряд вполне объективных причин. Вскоре после выступления декабристов и незадолго до своей смерти умудренный историческим знанием Н. М. Карамзин писал П. А. Вяземскому: «Бог спас нас 14 декабря от великой беды. Это стоило нашествия французов...» [Карамзин: 169]. А Толстой в пору создания «Войны и мира» утверждал: «На что много любителей Наполеона, а ни один поэт еще не сделал из него образа; и никогда не сделает» [Толстой 1928-1958. 15: 242]. Попытка наполеоновского реванша в 1825 г., характеры главных деятелей революционного движения не содержали в себе необходимых предпосылок для создания полноценного эпоса.

Уже первые критики, писавшие о «декабристских» поэмах Некрасова, если только у них не было конъюнктурных, строго «мундирных» задач, признавали их малую художественную состоятельность сравнительно с великими созданиями поэта 1840-1860-х гг. Тем не менее сам Некрасов был доволен произведенным на публику впечатлением. 26 февраля 1873 г. он сообщал брату Федору Алексеевичу: «Моя поэма “Кн. Волконская”, которую я написал летом в Карабихе, имеет такой успех, какого не имело ни одно из моих прежних писаний. <..> Литературные шавки меня щиплют, а публика читает и раскупает» [Некрасов 15-2: 12]. Между тем этот успех во многом объяснялся лубочной стилистикой произведения. Нельзя сбрасывать со счетов и фактографическую новизну некрасовских поэм начала 1870-х гг. Подробнейшим образом переложенные рифмованными стихами никому в ту пору не известные записки Волконской, точно так же, как рассказанные в рифму посвященные княгине Е. И. Трубецкой фрагменты записок А. Е. Розена (изданы в Мюнхене в 1869 г. и запрещены к печатанию в России), разумеется, привлекали читающую публику. Явная оппозиционность этих поэм, их устремленный к революционным потрясениям религиозный идеал тоже вполне отвечали запросам «передовой общественности». Впрочем, возможно, с точки зрения просветительской фактографии они не утратили своего значения для юношества и по сегодняшний день.

И для Толстого в 1870 гг., и для Некрасова обращение к теме декабристов прежде всего определялось остро современной (насколько реалистичной, настолько же и умозрительной) задачей: поиском путей 
соединения русских привилегированных сословий с народным миром. По этому поводу И. И. Сизова, рассматривая творческую концепцию «декабристского» произведения Толстого конца 1870-х гг., совершенно справедливо заметила: «Народ, трудовое крестьянство (земледельцы) представлялись Толстому идеалом общественной жизни и главным положительным героем. Развитие линии дворянского героя предполагало поиск путей сближения с народом» [Сизова 2019: 106]. В свою очередь, Некрасов откровенно любовался «мужицкими» чертами в образе своего дедушки, воспевал освоенное сибирским изгнанником искусство пахаря. В цикле «Русские женщины» жены декабристов открывали для себя духовный свет народной жизни и сами прикасались к ней своими страдальческими судьбами. Тем не менее этот «объединительный» (и важнейший) сюжет оказался в одном случае только намеченным, в другом - хотя и реализованным, но художественно несовершенным. Впрочем, тема декабризма, обозначенная Толстым и Некрасовым как тема национального единства - это, прежде всего, тема подлинных и подложных ценностей русского мира, которая требует отдельного рассмотрения уже за пределами этой статьи. И она, безусловно, не обещает быть простой.

28 января 1878 г., вскоре после смерти Некрасова, Толстой написал Н. Н. Страхову: «О Некрасове я недавно думал. По-моему, его место в литературе будет место Крылова. То же фальшивое простонародничанье и та же счастливая карьера - потрафил по вкусу времени - и то же невыработанное и не могущее быть выработанным - настоящее присутствие золота, - хотя и в малой пропорции и в неподлежащей очищению смеси» [Толстой 1928-1958. 62: 378]. Далеко не все справедливо в этом очень субъективном суждении о двух великих поэтах XIX в. Оба они неотделимы от народного русского самосознания. Но применительно к «Дедушке» и к «Русским женщинам» (именно к этим поэмам) слова Толстого выглядят, пожалуй, наименее спорными.

Впрочем, и сам Толстой, несмотря на грандиозный «побочный эффект» работы над «декабристским» замыслом - «Войну и мир», оказался не властен написать подлинно эпическое, народное произведение на материале собственно движения дворянских революционеров. На страницах творческой истории романа о декабристах $1870-$ х гг. в академическом собрании сочинений писателя И. И. Сизова выразительно обрисовала момент творческого «обрыва», наступивший однажды 
в этой работе Толстого: «Насколько значимым представлялся автору декабристский роман, видно из письма к П. Н. Свистунову от 25 декабря 1878 г.: “Дело, которое занимает меня, для меня теперь почти так важно, как моя жизнь” <..>. Тем не менее, в феврале 1879 г. роман был оставлен на пике творческих исканий. “Здоровье мое всё нехорошо, но работаю очень много и страстно, хотя ничего не пишу”. Это, по сути, подведение итогов в письме к Н. Н. Страхову от $13 \ldots 14$ февраля 1879 г. <..>. Эпоха 1820-х годов вновь увлечет Толстого в годы первой русской революции и позднее (1904-1905, 1908), но работа над произведением не возобновится» [Сизова 2014: 693-694].

Среди позднейших высказываний писателя о причинах неудачи «декабристского» замысла, как правило, не авторизованных, засвидетельствованных третьими лицами, два представляются наиболее значительными. Первое из них как совершенно достоверное однажды привел В. В. Розанов: «Кстати, о последнем, так удачно начавшемся романе, мне пришлось услышать мнение самого Толстого. Хотя и не мне сказанное. “Декабристы” не были серьезными людьми. Это не были серьезные характеры. 14 декабря было эпизодом их жизни, пожалуй, их возраста и настроения, а не плодом какой-нибудь страшной решимости, какую принимает убежденный человек как вывод из всей жизни. И я перестал писать роман, видя, что для него нет сюжета, не может хватить содержания"» [Розанов: 233]. И второе суждение, записанное П. А. Сергеенко, - в ответ на вопрос, будет ли когда-нибудь закончен роман: «Нет, я навсегда оставил эту работу, - ответил Лев Николаевич неохотно, $-<\ldots>$ потому что не нашел в ней того, чего искал, т. е. общечеловеческого интереса. Вся эта история не имела под собою корней» [Сергеенко: 12].

Сказанное, впрочем, никоим образом не означало, что Толстой в поздние десятилетия жизни отказался от своевольных идеалов далекой творческой поры. Говоря о характере освоения материалов истории в «Войне и мире», В. И. Щербаков проницательно замечает: «Очевидно, что толстовская “правда" - это глубоко субъективное представление Толстого о том времени, а не убеждение, сложившееся на основе изучения каких-то фактов, неведомых историкам, ибо он сам черпал факты в основном из трудов тех же историков, нередко перенося целые страницы их “лживых” описаний в текст “Войны и мира”. < ..> Постижение истории для Толстого - это именно “воля и представление”, 
мифотворческое преображение фактического материала. История для Толстого - это прошлое, которое можно изменить» [Щербаков: 306].

Речь между тем идет еще и о некоем глубоко религиозном, в духе мятежной современности, духовном переосмыслении прошлого. Нам уже неоднократно приходилось говорить о том, что собственно «Война и мир» заключала в себе грандиозную попытку художественного пересотворения вселенной на основе субъективно-авторских понятий о жизни: «Природа больших и малых конфликтов, которые возникают в романе, при всем психологическом их разнообразии, как правило, имеет единую и совершенно определенную первопричину. Это покушение цивилизации (“головного”, отвлеченного, оформленного, сознательного начала в мироздании) против естественного бытия. Название "Война и мир", которое часто и на разные лады интерпретировалось всеми, кто размышлял о толстовском шедевре, прежде всего означает именно такое противостояние $<\ldots>$ естественной жизни и цивилизации - согласно представлениям Толстого, жизни и нежизни. Действующие лица романа и до некоторой степени целые народы проходят в “Войне и мире" через бесконечные “ловушки” цивилизации, чтобы самим ходом событий, в дальнейшей жизни и даже в смерти приблизиться к торжеству толстовской эмоциональной правды и “данного нам в ощущениях" (“прелести” бытия, как любит говорить писатель) безличного сверхчувственного начала вселенной» [Гулин 2020: 172].

Далеко не случайно в «декабристском» эпилоге романа, именно в связи с возмущенными высказываниями Безухова о правительстве появилась и взятая в скобки многозначительная авторская ремарка: «Все слишком натянуто и непременно лопнет, - говорил Пьер (как, с тех пор, как существует правительство, вглядевшись в действия какого бы то ни было правительства, всегда говорят люди)» [Толстой 1928-1958. 12: 182]. Эти почти иронические слова между тем содержали в себе не только наблюдение за парадоксами человеческого сознания, но и некий окончательный вывод, к которому, по мысли Толстого, все же нельзя не прийти, вникая в самую природу государственности. Сквозная формула толстовского творчества «Нет в мире виноватых», мысль о попираемом цивилизацией естественном блаженстве всех живущих были слишком хорошо различимы в «Войне и мире». Родственные декабризму западные учения о построении земного рая, кажется, уже в 
то время готовы были найти в Толстом одного из наиболее своеобразных, ярких и масштабных своих последователей.

На рубеже 1870-1880-х гг. началась титаническая, обращенная непосредственно в жизнь, толстовская попытка всемирного - бескровного, как полагал он, переворота. Именно теперь, в пору беспрецедентной по интенсивности, в сущности, революционной борьбы со всем цивилизованным миром (но главным образом - с русской цивилизацией!) «декабристские начала» его жизни достигли своего всемерного развития. Так что и сами декабристы, их политическое движение, показались писателю только одним из цивилизованных покушений против естественной, вечной - божественной, согласно убеждениям Толстого, жизни непринужденного чувства. Тем не менее, своим пониманием всемогущего художника Толстой и в эти поздние годы прекрасно уловил бесперспективность темы декабристов как первоосновы для национального художественного эпоса.

$\mathrm{XX}$ век - время всемерного утверждения на русской почве (лишь с небольшими идеологическими оговорками) декабристского мифа. Восторженные или просто похвальные отзывы о революционерах 1825 г., культовые образы декабристов за те два столетия, когда их дело набирало силу, претворялось в жизнь, шло к своему вырождению, сделались общим местом русской исторической и художественной литературы. И все же ничего подлинно эпического, национально значимого на этой обильно возделанной почве так и не взошло. Возможно, для появления всходов здесь не хватало иного, найденного за пределами декабризма отношения к историческому явлению вместе с готовностью учитывать печальный опыт заблуждений, выстраданный поколениями предков.

\section{Список литературы Источники}

Волконский С. Г. Записки. СПб.: Синод. тип., 1902. 548 с.

Гериен А. И. Полн. собр. соч.: в 30 т. М.: Изд-во АН СССР, 1954-1966.

Гольденвейзер А. Б. Вблизи Толстого. М.: Худож. лит., 1959. 487 с.

Достоевский Ф. М. Полн. собр. соч.: в 30 т. Л.: Наука, 1980. Т. 21: Дневник писателя, 1873: Статьи и заметки, 1873-1878. 551 с.

Карамзин Н. М. Письма Н. М. Карамзина к князю П. А. Вяземскому // Старина и новизна: Исторический сборник, издаваемый при обществе ревнителей русского исторического просвещения в память императора Александра III. СПб.: Тип. М. М. Стасюлевича, 1897. Кн. 1. С. 1-204. 
Летописи Государственного литературного музея. М.: Гос. лит. музей, 1938. Кн. III: Декабристы / ред. Н. П. Чулков. 566 с.

Некрасов Н. А. Полн. собр. соч. и писем: в 15 т. СПб.: Наука, 1981-2000.

Розанов В. В. На закате дней: Л. Толстой и быт // Розанов В. В. О писательстве и писателях. М.: Республика, 1995. С. 231-236.

Сергеенко П. А. Как живет и работает гр. Л. Н. Толстой. М.: Тов-во И. Н. Кушнерев и $\mathrm{K}^{\circ} .1898 .106 \mathrm{c}$.

Толстой Л. Н. Полн. собр. соч.: в 100 т. М.: Наука, $2000-\ldots$

Толстой Л. Н. Полн. собр. соч.: в 90 т. М.: Худож. лит., 1928-1958.

\section{Исследования}

Васильева Е. Б. А. И. Герцен и Н. П. Огарев о декабристах // Актуальные проблемы исторических исследований: взгляд молодых учёных. Новосибирск: Параллель, 2011. С. $67-73$.

Гулин А. В. Богучаровский «бунт» в «Войне и мире» Л. Н. Толстого: источники, философия, поэтика // Studia Litterarum. 2020. Т. 5, № 1. C. 162-177. DOI: 10.22455/2500-4247-2020-5-1-162-177

Гулин А. В. Соборность или «роевое чувство»? (Русский мир 1812 года в «Войне и мире» Л. Н. Толстого) // Вестник тверского государственного университета. Серия «Филология». 2018. № 3. С. 11-22.

Гулин А. В. Роман «Кюхля» и декабристский миф: вступительная статья // Тынянов Ю. Н. Кюхля. М.: Детская литература, 2003. С. 5-20.

Сизова И. И. Лев Толстой в работе над романом «Декабристы» // Два века русской классики. 2019. № 1. C. 104-117. DOI: 10.22455/2686-7494-2019-1-1-104-117

Сизова И. И. Творческая история незавершенного романа «Декабристы» // Толстой Л. Н. Полн. собр. соч.: в 100 т. М.: Наука, 2014. Т. 9. С. 669-694.

Щербаков В. И. Война 1812 года в романе Л. Н. Толстого «Война и мир» // 1812 год и мировая литература. М.: ИМЛИ РАН, 2013. С. 235-318. 


\section{References}

Vasileva, E. B. "A. I. Gertsen i N. P. Ogarev o dekabristakh" [“A. I. Herzen and N. P. Ogarev on the Decembrists"]. Aktual'nye problemy istoricheskikh issledovanii: vzgliad molodykh uchionykh [Actual Issues of Historical Research: View of Young Scientists]. Novosibirsk, Parallel Publ., 2011, pp. 67-73. (In Russ.)

Gulin, A. V. “Bogucharovskii 'bunt' v 'Voine i mire' L. N. Tolstogo: istochniki, filosofiia, poetika" ["The 'Rebellion' in Bogucharovo in Leo Tolstoy's 'War And Peace': Sources, Philosophy, Poetics”]. Studia Litterarum, vol. 5, no. 1, 2020, pp. 162-177. DOI: 10.22455/2500-4247-2020-5-1-162-177 (In Russ.)

Gulin, A. V. 'Sobornost' ili 'roevoe chuvstvo'? (Russkii mir 1812 goda v 'Voine i mire' L. N. Tolstogo)" ["Conciliarity or 'Swarm Feeling'? (Russian World of 1812 in L. N. Tolstoy's 'War and Peace')"]. Vestnik Tverskogo Gosudarstvennogo Universiteta. Seriia "Filologiia", no. 3, 2018, pp. 11-22. (In Russ.)

Gulin, A. V. "Roman 'Kiukhlia' i dekabristskii mif: vstupitel'naia stat'ia" [“The Novel 'Kyukhlya' and the Decembrist Myth: Introduction”]. Tynianov, Ju. N. Kiukhlia [Kyukhlya]. Moscow, Detskaia literatura Publ., 2003, pp. 5-20. (In Russ.)

Sizova, I. I. "Lev Tolstoi v rabote nad romanom 'Dekabristy". [“Leo Tolstoy Working on the Novel 'The Decembrists"']. Dva veka russkoi klassiki, no. 1, 2019, pp. 104-117. DOI: 10.22455/2686-7494-2019-1-1-104-117 (In Russ.)

Sizova, I. I. "Tvorcheskaia istoriia nezavershennogo romana 'Dekabristy"' ['Creative History of the Unfinished Novel 'The Decembrists."]. Tolstoi, L. N. Polnoe sobranie sochinenii: v 100 tomah [Complete Works: in 100 vols.], vol. 9. Moscow, Nauka Publ., 2014, pp. 671-696. (In Russ.)

Shherbakov, V. I. "Voina 1812 goda v romane L. N. Tolstogo 'Voina i mir." ["The War of 1812 in Leo Tolstoy's Novel 'War and Peace.'] 1812 god i mirovaja literatura [The Year 1812 and World Literature]. Moscow, IWL RAS Publ., 2013, pp. 235-318. (In Russ.) 


\title{
Образ газеты и значение периодической прессы как одной из основ информационного мира в романе И. А. Гончарова «Обломов»
}

\begin{abstract}
Аннотация: Статья посвящена анализу художественных функций образа газеты в романе И. А. Гончарова «Обломов» и осмыслению нравственно-философских итогов противоборства главного героя с профанными информационными вызовами внешней среды. Особое внимание уделяется смысловому наполнению парадигмы Обломов - информационный мир, интерпретируемой с учетом богатого опыта работы Гончарова в газетно-редакторской сфере. Автор статьи доказывает, что одним из центральных постулатов в нравственно-философской концепции писателя является сохранение человечности. Диалоги героев и столкновение их позиций показывают, что гуманность в понимании Обломова перекликается с соответствующим ее осмыслением Гончаровым, раскрывают сложное и многогранное мировидение писателя. В исследовании намечается эволюция отношения к информационной модели в русской классической литературе и рассматривается вопрос о соразмерности между внешней инерцией и внутренней динамикой, свойственными Илье Ильичу Обломову. Выдвигается гипотеза о напряженной духовной жизни Обломова, расшифровывается целесообразность произнесения главным героем имени Пушкина.
\end{abstract}

Ключевые слова: И. А. Гончаров, «Обломов», газета, цензура, «реальное направление», обличительные тенденции, информационный мир, А. С. Пушкин.

Информация об авторе: Иван Владимирович Пырков, доктор филологических наук, профессор, Саратовская государственная юридическая академия, ул. Чернышевского, 104, 410028 г. Саратов, Россия.

ORCID ID: https://orcid.org/0000-0003-3480-3824.

E-mail: allekta@yandex.ru

Дата поступления статьи в редакиию: 03.02 .2021

Дата одобрения статьи рецензентами: 14.04 .2021

Дата публикации статьи: 28.06.2021

Для циттирования: Пырков И. В. Образ газеты и значение периодической прессы как одной из основ информационного мира в романе И. А. Гончарова «Обломов» // Два века русской классики. 2021. Т. 3, № 2. С. 120-137. https://doi.org/10.22455/2686-7494-2021-3-2-120-137 


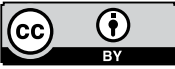

This is an open access article distributed under the Creative Commons Attribution

4.0 International (CC BY 4.0)
Dva veka russkoi klassiki,

vol. 3, no. 2, 2021, pp. 120-137. ISSN 2686-7494

Two centuries of the Russian classics, vol. 3, no. 2, 2021, pp. 120-137. ISSN 2686-7494

Research Article

(C) 2021. Ivan V. Pyrkov

Saratov State Law Academy, Saratov, Russia

\title{
The Newspaper and Other Markers of the Information World in the Novel Oblomov by Ivan Goncharov
}

\begin{abstract}
The article is devoted to the analysis of the artistic functions of the image of newspaper in the novel by I. A. Goncharov Oblomov and the comprehension of moral and philosophical results of the confrontation of protagonist with the profane information challenges of the external environment. Particular attention is paid to the semantic content of the Oblomov paradigm - the information world, interpreted taking into account the rich experience of Goncharov's work in the newspaper editorial field. The author of the article proves that one of the central tenets in the moral and philosophical concept of the writer is the preservation of humanity. The dialogues of heroes and the clash of their positions show that humanity in Oblomov's understanding echoes the corresponding understanding of it by Goncharov, revealing the complex and multifaceted worldview of the writer. The study outlines the evolution of attitudes towards the information model in Russian classical literature and examines the issue of the proportionality between external inertia and internal dynamics characteristic of Ilya Ilyich Oblomov. A hypothesis is put forward about the intense spiritual life of Oblomov, the expediency of pronouncing the name of Pushkin by the protagonist is deciphered.
\end{abstract}

Keywords: Ivan Goncharov, Oblomov, newspaper, censorship, "real direction", accusatory tendencies, the information world, Aleksandr Pushkin.

Information about the author: Ivan V. Pyrkov, DSc in Philology, Professor, Saratov State Law Academy, 104 Chernyshevskogo str., 410028 Saratov, Russia. ORCID ID: https:// orcid.org/0000-0003-3480-3824

E-mail: allekta@yandex.ru

Received: February 03, 2021

Approved after reviewing: April 14, 2021

Published: June 28, 2021

For citation: Pyrkov, I. V. “The Newspaper and Other Markers of the Information World in the Novel Oblomov by Ivan Goncharov." Dva veka russkoi klassiki, vol. 3, no. 2, 2021, pp. 120-137. (In Russ.) https://doi.org/10.22455/2686-7494-2021-3-2-120-137 
В судьбе И. А. Гончарова отечественная периодика занимала особое место. Ю. М. Лощиц обращает внимание на кропотливый и, в сущности, неблагодарный труд, проделанный Гончаровым - редактором правительственной газеты «Северная почта»: «С первых же месяцев своего редакторства Гончаров оказался по рукам и ногам опутан неотлагательными административными заботами <..>. Иван Александрович попытался для начала изменить хотя бы внешний облик газеты, улучшить литературный уровень её материалов $<\ldots>$. А ведь и корректуры надо прочитывать ему самому. И самому править статьи сотрудников» [Лощиц: 259-260].

Редакторские будни отразились в гончаровском эпистолярном наследии. Так, в письме к Д. Л. Кирмаловой писатель делится концептуально значимыми размышлениями о работе на посту главного редактора правительственной газеты, косвенно затрагивая актуальную для него на протяжении долгих лет оппозицию: «служба - творчество». «Ну, что сказать? Сказал бы: скучно, пора перестать жить, да некогда и подумать об этом. Работа поглощает меня всего, а это имеет именно ту хорошую сторону, что не дает замечать времени, жизни. Равнодушие ко всему (курсив Гончарова. - И. П.) делает меня до того прилежным, что министр третьего дня выразил удивление, сказав, что он не ожидал от меня или ожидал всего, кроме трудолюбия, считая меня за Обломова. <...> Никуда не хожу, ничего не читаю, кроме “Северной почты” $[$ [Суперанский: 430].

В 1856 г. Гончаров принимает на себя обязанности цензора Петербургского цензурного комитета, в 1865 г. становится членом Совета по делам печати. Гончарову, выступавшему относительно целого ряда периодических изданий («День», «Санкт-Петербургские ведомости», «Северная почта» и др.) в роли цензора, автора, редактора, специфика газетной среды и информационного мира в целом была хорошо известна. 
Закономерно, что данное обстоятельство, существенно дополняющее фонд биографических сведений о Гончарове, уточняющее его писательский портрет, вызывает неослабевающий интерес исследователей на протяжении многих лет [Ковалёв; Гайнцева; Греков; Котельников; Труайа Анри; Зубков].

Однако, несмотря на важность и концептуальное значение [Пырков 2012], образ газеты в творчестве Гончарова до сих пор остается неизученным [Семёнов 2012].

Проблема столкновения Ильи Ильича Обломова с информационным потоком в многоразличных его воплощениях (слухи, людская молва, письмо) также до сих пор не исследована. Проанализируем несколько ключевых эпизодов из романа «Обломов», в которых образ газеты получает метафорическое обобщение, и рассмотрим столкновение главного героя с чуждым ему, внешним, не затрагивающим смысловых глубин жизни информационным потоком.

Характеризуя замкнутую жизнь Ильи Ильича Обломова и подчеркивая внешнюю инерцию героя, автор замечает: «На этажерках, правда, лежали две-три развернутые книги, валялась газета, на бюро стояла и чернильница с перьями; но страницы, на которых развернуты были книги, покрылись пылью и пожелтели; видно, что их бросили давно; нумер газеты был прошлогодний, а из чернильницы, если обмакнуть в нее перо, вырвалась бы разве только с жужжаньем испуганная муха» [Гончаров 2000: 7]. Глубоко символично, что «нумер газеты» датирован прошлым годом - в обломовском полутемном жилище все так или иначе тяготеет к прошлому, тогда как времени настоящему, сегодняшнему дню пробиться сюда не легче, чем солнечным лучам сквозь спущенные «сторы» [Гончаров 2000: 6]. Семантически значим отнесенный к газете глагол «валялась», демонстрирующий, насколько герой пренебрежительно и критически воспринимает газетную информацию, насколько далек он от злобы дня, которая неизбежно отражается в газетном содержании. Примечательно, что в романе «Обрыв» автор помещает слово «газета» в принципиально иной контекст: Борис Райский объясняет Леонтию Козлову весомость газеты в новых социально-экономических и политических обстоятельствах: «Ах ты, старовер! как ты отстал здесь! О газетах потише - это Архимедов рычаг: они ворочают миром...» [Гончаров 2004: 209]. 
«Жизнь трогает», [Гончаров 2000: 166] - жалуется Обломов Штольцу и предпринимает отчаянные усилия, чтобы отмахиваться от беспокоящих «щипков» действительности. В этой постоянно ведущейся упорной борьбе за право «выделки покоя» [Гончаров 2000: 180] свежая газета Илье Ильичу не помощник. Он довольствуется прошлогодним «нумером», возможно так ни разу и не открытым. В Обломовке, где рос и воспитывался главный герой, информационный поток сводился к нулю: письма предпочитали не получать (по принципу лучшая информация - ее отсутствие), если всё же получали по недосмотру, то годами, как это произошло с письмом некоего Радищева, помещика-соседа, не открывали. Газеты же если и читали, то «третьегодичные». Отец Обломова, Илья Иванович, долгим зимним вечером мог почитать для собравшейся семьи «третьегодичные ведомости» [Гончаров 2000: 136]. Девиз обломовцев, сформулированный всё тем же главой семейства, звучал характерно: «То ли бы дело, если б каждый день как вчера, вчера как завтра!..» [Гончаров 2000: 129]. За этот жизненный алгоритм и ведёт борьбу Илья Ильич Обломов, впитавший вместе с молоком матери главные темпоральные ценности обломовского мировосприятия.

«Да ты поэт, Илья!» - восклицает Штольц, когда Обломов доверяет ему свою мечту о семейном счастье на фоне идеализированного усадебного пейзажа. «Да, поэт в жизни, потому что жизнь есть поэзия» [Гончаров 2000: 178-179], - отвечает, в соответствии со своей жизненной философской программой, Илья Ильич. В обломовском плане по обустройству имения мы видим пышные цветники, березовую рощу, семейный ужин, неспешное общение с друзьями. И никаких газет даже «третьегодичных».

В экспозиционной части романа автор изображает амбивалентную природу главного героя, противопоставляющего общепринятому пониманию исторического прогресса поэзию повседневности, невольно переносящего ментальную проекцию идиллической Обломовки в реальный мир, показываемый автором в том числе и сквозь призму газетных страниц.

Продолжая раскрывать образ Ильи Ильича Обломова, Гончаров пишет: «Что ж он делал дома? Читал? Писал? Учился?

Да: если попадется под руку книга, газета, он ее прочтет» [Гончаров 2000: 60]. Правда, чтение это своеобразное - герой или забудет о прочитанном, или отложит, не дочитав, до лучших времен. 
Андрей Штольц прямо спрашивает своего друга: «Ни газеты не видать... - Читаешь ли ты газеты?» И получает прямой, хотя далеко не прямолинейный ответ: «Нет, печать мелка, портит глаза... и нет надобности: если есть что-нибудь новое, целый день со всех сторон только и слышишь об этом» [Гончаров 2000: 169].

Штольц спрашивает не из любопытства, и не только потому, что уличает Илью Ильича во внешней бездеятельности на фоне постоянно спешащей петербургской жизни, где набирают обороты буржуазные отношения. Для Штольца информационная замкнутость сама по себе непредставима. Ежедневные сводки, сведения экономического характера, оповещение о важных городских событиях, политические новости - без газетных страниц, информирующих о действительности и её моделирующих, капиталистическая машина не могла набрать должного хода.

В ответных словах Обломова легко угадывается ирония: мелкая печать, как можно предположить, означает несущественность газетной тематики, её сиюминутность, не связанную с теми требованиями основательности и прочности, которые Обломов предъявлял к жизни.

Действие романа приходится на середину 1840-х гг., в это время газетная периодика была проникнута мотивами политической борьбы, знакомила читателей с художественными и публицистическими произведениями А. И. Герцена, В. Г. Белинского, Н. А. Некрасова, И. С. Тургенева, П. А. Вяземского, А. С. Хомякова, Ф. В. Булгарина и многих других авторов, относящихся к противоположным идейным лагерям. По заключению Т. А. Семёновой, «Русская печатная газета $<\ldots>$ становится в первой половине XIX века ареной борьбы <...> за читателя» [Семёнова 2010]. У Обломова - своя «арена борьбы», Илья Ильич сражается за право не быть как «другие», за уникальность своего маленького мира.

Однако в диалоге с одним из своих «утренних визитеров» литературным поденщиком Пенкиным, привносящим в жилище Ильи Ильича едкий запах типографской краски, дух газетных новостей, Обломов доказывает, что прекрасно разбирается в проблематике и тематической выборке современной ему периодики. Буквально не поднимаясь с дивана, Илья Ильич в пух и прах разбивает идеологию ратующего за «реальное направление» и обличительные тенденции беллетристагазетчика: 
$-<\ldots>$ Читали мою статью?

- Нет.

- Я вам пришлю, прочтите.

- О чем? - спросил сквозь сильную зевоту Обломов.

- О торговле, об эмансипации женщин, о прекрасных апрельских днях, какие выпали нам на долю, и о вновь изобретенном составе против пожаров. Как это вы не читаете? Ведь тут наша вседневная жизнь. <..>

- Много у вас дела? - спросил Обломов.

- Да, довольно. Две статьи в газету каждую неделю, потом разборы беллетристов пишу <...> [Гончаров 2000: 26].

Илья Ильич, продолжая зевать от скуки, слушает Пенкина до тех пор, пока тот не заговаривает о «презрении над падшим человеком» [Гончаров 2000: 27].

- Что ж еще нужно? И прекрасно, вы сами высказались: это кипучая злость - желчное гонение на порок, смех презрения над падшим человеком... тут все!

- Нет, не все! - вдруг воспламенившись, сказал Обломов. - Изобрази вора, падшую женщину, надутого глупца, да и человека тут же не забудь. Где же человечность-то? Вы одной головой хотите писать! - почти шипел Обломов. - Вы думаете, что для мысли не надо сердца? Нет, она оплодотворяется любовью. Протяните руку падшему человеку, чтоб поднять его, или горько плачьте над ним, если он гибнет, а не глумитесь. $<\ldots>$ Какое же тут искусство, какие поэтические краски нашли вы? Обличайте разврат, грязь, только, пожалуйста, без претензии на поэзию.

- Что же, природу прикажете изображать: розы, соловья или морозное утро, между тем как все кипит, движется вокруг? Нам нужна одна голая физиология общества; не до песен нам теперь...

- Человека, человека давайте мне! - говорил Обломов. - Любите его... [Гончаров 2000: 26-27].

То, что для Пенкина, характерного представителя кипучей газетной среды, с ее обличениями, спорами, идейными столкновениями, неотложной сиюминутной злободневностью, оказывается не просто хлебом насущным, а прочно ассоциируется с прогрессом, для Обломова - топтание на месте, механическая деятельность ради деятель- 
ности. «И всё писать, всё писать, как колесо, как машина: пиши завтра, послезавтра; праздник придет, лето настанет - а он все пиши? Когда же остановиться и отдохнуть? Несчастный!» [Гончаров 2000: 29]. Илья Ильич догадывается, что прошлогодний «нумер» газеты мало чем отличается от сегодняшнего, он с первого взгляда, при всей своей внешней инфантильности (или, как сформулировал один из комментаторов, «застарелом младенчестве» [Адян 1992]), безошибочно отличает вечное от сиюминутного, значимое от несущественного. Представление Обломова о прогрессе базируется на неизменных ценностных установках, манифестированных им, в частности, в диалоге-полемике с Пенкиным.

Более того, за вдохновенной отповедью Обломова угадывается взгляд автора на односторонность «обличительного направления», в обломовском голосе отчетливо слышатся гончаровские нотки. «Вопросы о религии, о семейном союзе, о новом устройстве социальных начал, об эмансипации женщины <...> не суть частные, подлежащие решению той или другой эпохи, той или другой нации, того или другого поколения вопросы, - писал многое повидавший к тому времени как редактор и цензор Гончаров в предисловии к роману “Обрыв”. - Это общие, мировые, спорные вопросы, идущие параллельно с общим развитием человечества $<\ldots>>$ за них ведется постоянная борьба в науке, в недрах церкви, на политической арене, всюду» [Гончаров 1952-1955. 8: 154].

Позицию романиста Гончарова ошибочно было бы считать консервативной, гончаровское мировидение сложно и многогранно. В. И. Мельник в книге «И. А. Гончаров» подчеркивает: «Гончаров был умным цензором, он отвергал пустое зубоскальство и “обличительство”, но не придирался к пустякам и щадил настоящую литературу. $<\ldots>$ Цензорская деятельность Гончарова выпала на тот период, когда в русское общество начинают проникать $<\ldots>$ вульгарноматериалистические $<\ldots>$ идеи. Вот образец его отзыва на статьи известного «разрушителя эстетики» Д. И. Писарева: «Г[осподин] Писарев с свойственной ему заносчивостью (но не без дарования и живой выработанной речью) разрушает господствовавшие доселе начала критики и эстетический вкус <..>. Самого Пушкина разумеет как рифмоплета, как поверхностный, слабый и мелкий ум, не способный сознавать и оценить серьезных явлений и потребностей своего времени». Крити- 
ческое дарование за Писаревым цензор признает, но циничного отношения к Пушкину ему простить не может. В разрушении эстетического начала Гончаров $<\ldots>$ видел разрушение основ самой жизни $<\ldots .>$ » [Мельник: 45].

Гончаров не приемлет крайностей, для него переустройство общества может быть только эволюционным, основанным на почитании традиций и гуманности. Сохранение человечности - один из центральных постулатов в нравственно-философской концепции писателя. Диалог Обломова с Пенкиным не просто наводит на размышление о том, что гуманность в понимании Ильи Ильича перекликается с гуманностью в понимании Гончарова, но и многое проясняет в позиции Гончарова-цензора.

Немаловажную роль газета играет в движении сюжета романа. Ольга Ильинская, задавшись целью приобщить Обломова к деятельности, мечтала «...как “прикажет ему прочесть книги”, которые оставил Штольц, потом читать каждый день газеты и рассказывать ей новости, писать в деревню письма, дописывать план устройства имения, приготовиться ехать за границу <...>. И все это чудо сделает она, такая робкая, молчаливая, которой до сих пор никто не слушался, которая еще не начала жить! Она - виновница такого превращения!» [Гончаров 2000: 205].

Ольге удается на время «разбудить» Обломова: «Он догнал жизнь, то есть усвоил опять все, от чего отстал давно; знал, зачем французский посланник выехал из Рима, зачем англичане посылают корабли с войском на Восток; интересовался, когда проложат новую дорогу в Германии или Франции. $<\ldots>$ Он усвоил $<\ldots>$ то, что вращалось в кругу ежедневных разговоров в доме Ольги, что читалось в получаемых там газетах <...> [Гончаров 2000: 273].

Ольга Ильинская считает «ежедневное» чтение газет и пересказ газетных новостей одним из главных условий преображения Обломова. И Обломов действительно меняется, «догоняет жизнь», по выражению автора. Хотя его преображение связано, конечно, не с газетами, а с женским влиянием Ольги.

Чернильница Ильи Ильича теперь «полна чернил», на столе лежит «гербовая» бумага, он пишет Ольге глубоко прочувствованные письма, где ни разу не сталкиваются, как раньше, «что» и «который», он ходит с Ольгой в театр, он готов к переустройству Обломовки, он собирается 
за границу, он похож на «других», перед ним дилемма «теперь или никогда» [Гончаров 2000: 188]. «Он усвоил только то, что вращалось в кругу ежедневных разговоров в доме Ольги, что читалось в получаемых там газетах, и довольно прилежно, благодаря настойчивости Ольги, следил за текущей иностранной литературой. Все остальное утопало в сфере чистой любви» [Гончаров 2000: 273].

Обломов влюбился, однако «летняя, цветущая поэма любви как будто остановилась <...> [Гончаров 2000: 302]. Причин можно назвать немало. Одна из них, как мы полагаем, в прямом столкновении Обломова с внешним информационным потоком.

Захар, как называет его Гончаров, рыцарь «и со страхом, и с упреком» [Гончаров 2000: 67], задает Илье Ильичу вроде бы вполне безобидный вопрос, но смещает им парадигму восприятия Обломова, который как будто открывает глаза и видит происходящее совсем в ином, чем несколько мгновений назад, свете. Вопрос Захара Трофимовича выглядит невинно:

- Стало быть, свадьба-то после Рождества будет? - прибавил Захар.

- Какая свадьба? - вдруг встав, спросил Обломов.

- Известно какая: ваша! - отвечал Захар положительно, как о деле давно решенном. - Ведь вы женитесь?

- Я женюсь! На ком? - с ужасом спросил Обломов, пожирая Захара изумленными глазами.

- На Ильинской барыш... - Захар еще не договорил, а Обломов был у него почти на носу.

- Что ты, несчастный, кто тебе внушил эту мысль? - патетически, сдержанным голосом воскликнул Обломов, напирая на Захара.

- Что я за несчастный? Слава тебе Господи! - говорил Захар, отступая к дверям. - Кто? Люди Ильинские еще летом сказывали.

- Цссс!.. - зашипел на него Обломов, подняв палец вверх и грозя на Захара. - Ни слова больше! [Гончаров 2000: 319].

Если мелкую газетную печать Обломов просто не замечает, если «огромные бледные буквы» письма от старосты, полного тревожных известий о безрадостном сегодняшнем дне Обломовки («Пятую неделю нет дождей»; «Озимь ино место червь сгубил...»; «... нынешний год пошлем доходцу <...> тысящи яко две помене против того года <...» 
[Гончаров 2000: 35]) хоть как-то нейтрализуются имеющимся в запасе у Ильи Ильича пусть и идиллическим, но все же планом переустройства имения, то озвученная пестрой людской массой информация, врывающаяся во внутренний мир Ильи Ильича прямо с улицы, неприемлема и неодолима для Обломова.

Обломов потрясен. Любовь к Ольге преобразила его, помогла преодолеть скепсис и проявить свои лучшие качества («Это хрустальная, прозрачная душа; таких людей мало; они редки; это перлы в толпе!» [Гончаров 2000: 467] - скажет про своего друга проницательный Штольц). Но любовь сделала Обломова уязвимее. Оставаясь «поэтом в жизни», Илья Ильич представлял себе свадьбу как «поэтический миг», «венец счастья». Для Обломова немыслимо, что этот «миг» обсуждают «люди», говорят о нем «лакеи», «кучера». Глубоко личностный и неповторимый момент его судьбы, который еще пока только грезится «в розовой атмосфере» [Гончаров 2000: 320], как чудо, стал темой для пересудов. Илья Ильич Обломов в ужасе узнал, что личностно-интимная сфера его существования превратилась в информацию для "других", распространяющуюся «по лакейским, по магазинам, по рынкам» [Гончаров 2000: 322].

Любопытна оценка Обломова, сформулированная автором «Истории русской словесности» П. Н. Полевым: «В Обломове, человеке умном, сердечно-прекрасном, одаренном недюжинными способностями, обеспеченным хорошими материальными средствами, он (Гончаров. И. П.) представил нам несчастного, полубольного <...> маньяка, который сам лишает себя всяких прелестей жизни <...> [Полевой: 468]. Кстати, и про службу Гончарова Петр Николаевич Полевой высказывался весьма характерологично, замечая, что « 40 р. сер. с печатного листа» [Полевой: 468] в качестве гонорара за «Обыкновенную историю» не могут быть единственным доходом для жизни в столице.

Парадокс в том, что герой Гончарова, Илья Ильич Обломов, оказывается в каком-то смысле свободнее и независимее автора, поскольку Обломову не нужно отправляться каждый день на службу. Вот и подумаем теперь: разве допустит столь одержимый своей независимостью от времени и свободой от информации внешнего мира герой, чтобы кто-то посторонний, кроме, может быть Ольги, касался его мира внутреннего? Всего лишь обсуждение предстоящей свадьбы «людьми», мысль о публичности счастливой минуты заставляет потускнеть в его 
воображении «померанцевую ветку» [Гончаров 2000: 320]. Илья Ильич попытался вновь представить свадьбу в сияющем свете. «Но краски были уже не те: тут же, в толпе, был грубый, неопрятный Захар и вся дворня Ильинских, ряд карет, чужие, холодно-любопытные лица. Потом, потом мерещилось все такое скучное, страшное...» [Гончаров 2000: 320]. Гончаров вскрывает одно из важнейших психологических свойств Обломова - его принципиальную непубличность. Свойство, во многом воспитанное укладом жизни в Обломовке. Идиллический усадебный мир обломовцев был не создан для каких бы то ни было средств внешней связи. Как совершенно справедливо замечает И. Н. Сухих, даже само сопоставление выглядит странно: «Обломов и телеграф» [Сухих: 97]. Точно так же невозможно представить, что о личной жизни Обломова или о его семейном круге пишут газеты.

Свойство категорической непубличности - типично обломовская черта. Во всяком случае Лаврецкий из тургеневского «Дворянского гнезда» узнает и о жизни своей супруги в Париже, и о ее мнимой смерти именно из газет, смиряется с тем, что его жена стала настоящей «известностью» [Тургенев 1981. 6: 54]. В чеховской драме «Три сестры» из кармана военного доктора Чебутыкина привычно торчит газета, автор так и указывает в ремарке: «...он все время с газетой» [Чехов 1986. 13: 131]. Как будто все понимающий, но не имеющий возможности ничего изменить герой стремится спрятаться за фантомной информационной моделью от ощущения безысходности и беспомощности, свойственного трагическому мировосприятию эпохи «конца века» - "Fin de siècle".

Для Обломова, человека, живущего по собственному, обломовскому летоисчислению, подобное невозможно в принципе.

И все же не будем упускать из внимания амбивалентность гончаровского героя. Сфокусируем внимание на последней мизансцене с участием Обломова. Далеко позади осталось житье на Гороховой, позабыты планы о перемене жизни в Обломовке, Ольгино пение (Casta Diva, ария из оперы В. Беллини «Норма») не звучит больше, Илья Ильич нашел свою Милитрису Кирбитьевну, Агафью Матвеевну Пшеницыну, и провел несколько счастливых лет на Выборгской стороне, среди мира и тишины, в кругу любимой семьи. Для все понимающего Штольца такое развитие событий означает «никогда». Для все чувствующего Обломова - значит «теперь». 
— Ты ли это, Илья? - упрекал он. - Ты отталкиваешь меня, и для нее, для этой женщины!.. Боже мой! - почти закричал он, как от внезапной боли. - Этот ребенок, что я сейчас видел... Илья, Илья! Беги отсюда, пойдем, пойдем скорее! Как ты пал! Эта женщина... что она тебе...

- Жена! - покойно произнес Обломов.

Штольц окаменел.

- А этот ребенок — мой сын! Его зовут Андреем, в память о тебе! [Гончаров 2000: 483].

Ответ Обломова Штольцу полон не только драматизма, но прежде всего тихого внутреннего достоинства. Илья Ильич предстает перед читателями человеком внутренне свободным, самодостаточным и, что самое главное, не прекратившим ни на минуту духовного труда, безошибочно отделяющим главную информацию от второстепенной («Я не сплю, я все слышу...» [Гончаров 2000: 150]).

Перед последней встречей с Андреем Штольцем, в начале эпизода, Алексеев рассказывает Обломову новости. Образы большинства «утренних визитеров» так и останутся в читательской памяти изящно выточенными автором из лексического материала статуэтками. Но Алексееву, произносящему прописные истины («Никогда не надо предаваться отчаянию: перемелется - мука будет» [Гончаров 2000: 36], этому герою-спутнику, суждено выполнить еще одну, значимую для архитектоники романа и для более точной нюансировки портрета Обломова миссию.

Алексеев сообщает Илье Ильичу, которому нельзя больше спать после обеда из-за недавнего удара, о газетных новостях, услышанных от читавшего газету Дмитрия Алексеевича, сына Алексея Спиридоныча. Фамилия Алексеева несколько раз обыгрывается автором, возможно, намекающим в данном случае на передачу информации из уст в уста, от лица к лицу. Газетные новости доходят до Обломова не на прямую, а опосредованно, глухим отзвучьем, искривленным отражением.

- Да-с, иногда читаю, или другие читают, разговаривают, а я слушаю. Вот вчера у Алексея Спиридоныча сын, студент, читал вслух...

- Что ж он читал?

- Про англичан, что они ружья да пороху кому-то привезли. Алексей Спиридоныч сказали, что война будет. 
$<\ldots>$

- Ну, что еще нового в политике? - спросил, помолчав, Илья Ильич.

- Да пишут, что земной шар все охлаждается: когда-нибудь замерзнет весь.

- Вона! Разве это политика? - сказал Обломов.

Алексеев оторопел.

- Дмитрий Алексеич сначала упомянули политику, - оправдывался он, - а потом все сподряд читали и не сказали, когда она кончится. Я знаю, что уж это литература пошла.

- Что же он о литературе читал? - спросил Обломов.

- Да читал, что самые лучшие сочинители Дмитриев, Карамзин, Батюшков и Жуковский...

- А Пушкин?

- Пушкина нет там. Я сам тоже подумал, отчего нет! Ведь он хений, сказал Алексеев, произнося 2, как $x$ [Гончаров 2000: 478-479].

Обломов мгновенно реагирует на реестр литературных имен в газетном обзоре, куда не попадает почему-то Пушкин. Илья Ильич обнаруживает чуткость и подвижность мысли, доказывает, что внутренняя работа не останавливалась в нем ни на минуту. Автор, для которого имя Пушкина священно, доверяет произнести его на излете романа полудремлющему Обломову, а не деятельностному Штольцу. Отклик героя на газетные новости вновь возвращает нас к вопросу о внешней и внутренней деятельности.

Немецкий культуролог Эрих Фромм, размышляя о феномене «действия» и «бездействия» в книге «Искусство любить», по нашему мнению, оказывается близок к гончаровскому миропониманию в романе «Обломов». «Признав любовь деятельностью, - замечает Э. Фромм, мы сталкиваемся, однако, с определенной трудностью, которая состоит в неоднозначности слова “деятельность”. Под “деятельностью” <...> обычно понимается действие, предполагающее некоторую затрату энергии и влекущее за собой изменение существующего положения вещей. Так, деятельным считается человек, занимающийся бизнесом, изучающий медицину, работающий на конвейере <... . Все эти виды активности имеют между собой то общее, что все они направлены на достижение некоторой внешней цели. Что же касается мотивов деятельности, то они не принимаются во внимание. Вот, например, че- 
ловек, который взялся за нескончаемую работу, движимый чувством одиночества и неуверенности; или другой - движимый честолюбием или жадностью. В любом из этих случаев человек - раб своей страсти, и его активность есть на самом деле "пассивность", потому что он гоним этой страстью. Его роль “страдательная”, а не “действительная”. С другой стороны, человек, неподвижно сидящий и созерцающий безо всякой видимой цели, кроме разве что переживания своего единства с миром, считается “пассивным", потому что он ничего не “делает". Но на самом деле такое состояние сосредоточенной медитации - самая высшая форма деятельности из всех, какие возможны: деятельность души, возможная только при условии внутренней (курсив мой. - И. П.) свободы и независимости» [Фромм].

Называя имя Пушкина, произнося монолог «о человеке», до конца оставаясь «поэтом в жизни», занимаясь «выделкой покоя», отстаивая право на непубличность и свое собственное понимание исторического прогресса, Илья Ильич Обломов проявляет, конечно, внутреннюю свободу и независимость. Внешняя инерция главного героя оборачивается напряженной внутренней динамикой, одним из маркеров которой становится в тексте Гончарова парадигма «Обломов - газета», интегрирующаяся автором в более широкое противопоставление: Обломов - информационный мир.

Мы предполагаем, что самоироничное словосочетание «равнодушие ко всему», выделенное в одном из писем Гончарова-редактора курсивом, имеет, как и в случае с Обломовым, обратную сторону - участливое внимание и любовь ко всему. А возможно, писатель имеет в виду «равнодушие ко всему» в значении ко всему мелкому, несущественному. Трудно представить действительно равнодушным человека, первым из русских писателей отважившегося на путешествие «кругом света» на военном фрегате и, как известно, принявшим на себя на склоне лет воспитание и попечение детей своего покойного камердинера.

Нет сомнения в том, что возможность увидеть литературный процесс изнутри, знакомство с газетно-журнальной сферой, равно как и цензорский опыт, повлияли на творчество Гончарова. Рецепция всего корпуса художественных текстов писателя с учетом его редакторской и цензорской службы, при условии дальнейшей расшифровки эволюционного кода образа газеты и других маркеров информационного мира в русской классической литературе, перспективна как для результатив- 
ного осмысления закономерностей гончаровской поэтики, так и для реконструкции писательской репутации И. А. Гончарова.

\section{Список литературы \\ Источники}

Гончаров И. А. Полн. собр. соч. и писем: в 20 т. СПб.: Наука. 2000. Т. 4.495 с.

Гончаров И. А. Собр. соч.: в 8 т. М.: Худож. лит., 1955. Т. 8. 576 с.

Полевой П. Н. История русской словесности: в 3 т. СПб.: Изд-е А. Ф. Маркса, 1900. T. 3. 708 c.

Суперанский М. Ф. Ив. Ал. Гончаров и новые материалы к его биографии // Вестник Европы. 1908. № 12. С. 417-460.

Тургенев И. С. Полн. собр. соч. и писем: в 30 т. М.: АН СССР, 1978-2018.

Чехов А. П. Полн. собр. соч. и писем: в 30 т. М.: АН СССР, 1974-1983.

\section{Исследования}

Адян В. С. Застарелое младенчество: (к вопросу о гончаровском понимании природы обломовщины) // Материалы юбилейной гончаровской конференции 1987 г. Ульяновск: Симбирская книга, 1992. С. 86-94.

Гайнцева Э. Г. И. А. Гончаров в «Северной почте» (История одной газетной публикации) // Материалы Международной научной конференции, посвящённой 185-летию со дня рождения И. А. Гончарова). Ульяновск: Печатный двор, 1998. C. 261-267.

Греков В. Н. «Неумеренно горячий образ действий редакции» (И. А. Гончаров - цензор газеты «День») // Материалы V Международной научной конференции, посвящённой 200-летию со дня рождения И. А. Гончарова. Ульяновск: «Корпорация технологий продвижения», 2012. С. 319-326.

Зубов К. Ю. И. А. Гончаров-фельетонист на страницах «Санкт-Петербургских ведомостей» // Материалы VI Международной научной конференции, посвящённой 205-летию со дня рождения И. А. Гончарова. Ульяновск: «Корпорация технологий продвижения», 2017. С. 213-224.

Ковалёв И. А. И. Гончаров - редактор газеты «Северная почта» // Русская литература. 1958. № 2. С. 136-141.

Котельников В. А. И. А. Гончаров в цензурном ведомстве // Цензура в России: история и современность: сб. науч. тр. СПб.: Изд-во Рос. нац. библиотеки, 2013. Вып. 6. С. 247-278.

Лощии Ю. М. Гончаров. М.: Молодая гвардия, 1977. 351 с.

Мельник В. И. И. А. Гончаров. М.: Вече, 2012. 432 с.

Пььрков И. В. Письма Обломова // Вестник славянских культур. 2012. № 3 (25). C. 71-80.

Семёнова Т. А. Особенности развития газетного дела в России в первой половине XIX века // Молодой учёный. 2010. № 12 (23). С. 24-27. 
Семёнов А. Н. Концепт СМИ в структуре художественного текста И. А. Гончарова (роман «Обломов») // Материалы V Международной научной конференции, посвящённой 200-летию со дня рождения И. А. Гончарова. Ульяновск: «Корпорация технологий продвижения», 2012. С. 144-151.

Сухих И. Н. Проблемы поэтики А. П. Чехова. Л.: Ленинградский ун-т, 1987. $180 \mathrm{c}$.

Труайа Анри. «Мильон терзаний» Ивана Александровича Гончарова. (Перевод с французского М. А. Руковой). М.: Центр книги Рудомино, 2012. С. 111-114.

Фромм Эрих. Искусство любить. М.: Педагогика, 1990. С. 10-11.

\section{References}

Adian, V. S. "Zastareloe mladenchestvo: (k voprosu o goncharovskom ponimanii prirody oblomovshchiny)" ["Chronic Infancy: (on Goncharov's Understanding of the Nature of Oblomovism)"]. Materialy iubileinoi goncharovskoi konferentsii $1987 \mathrm{~g}$. [Materials of the Jubilee Goncharov Conference of 1987]. Ul'ianovsk, Simbirskaia kniga Publ., 1992, pp. 86-94. (In Russ.)

Gaintseva, E. G. “I. A. Goncharov v 'Severnoi pochte' (Istoriia odnoi gazetnoi publikatsii)" ["I. A. Goncharov in the 'Severnaya Pochta' (History of a Newspaper Publication)"]. Materialy Mezhdunarodnoi nauchnoi konferentsii, posviashchennoi 185-letiiu so dnia rozhdeniia I. A. Goncharova [Materials of the International Scientific Conference Dedicated to the $185^{\text {th }}$ Anniversary of I. A. Goncharov).]. Ul'ianovsk, Pechatnyi dvor Publ., 1998, pp. 261-267. (In Russ.)

Grekov, V. N. “'Neumerenno goriachii obraz deistvii redaktsii' (I. A. Goncharov tsenzor gazety 'Den'.") [“Unreasonably Hot Way of Action by the Editorial Board" (I. A. Goncharov as a Censor of the Newspaper 'Den')"]. Materialy V Mezhdunarodnoi nauchnoi konferentsii, posviashchennoi 200-letiiu so dnia rozhdeniia I. A. Goncharova [Proceedings of the $5^{\text {th }}$ International Scientific Conference Dedicated to the $200^{\text {th }}$ Anniversary of I. A. Goncharov]. Ul'ianovsk, Korporatsiia tekhnologii prodvizheniia Publ., 2012, pp. 319-326. (In Russ.)

Zubov, K. Iu. "I. A. Goncharov-fel'etonist na stranitsakh 'Sankt-Peterburgskikh vedomostei'." ["Goncharov-feuilletonist on the Pages of St. Petersburg Gazette”]. Materialy VI Mezhdunarodnoi nauchnoi konferentsii, posviashchennoi 205-letiiu so dnia rozhdeniia I. A. Goncharova [Proceedings of the $6^{\text {th }}$ International Scientific Conference Dedicated to the $205^{\text {th }}$ Anniversary of I. A. Goncharov]. Ul'ianovsk, Korporatsiia tekhnologii prodvizheniia, 2017, pp. 213-224. (In Russ.)

Kovalev, I. A. "Ivan Goncharov - redaktor gazety 'Severnaia pochta." ["Ivan Goncharov as an Editor of the Newspaper 'Severnaya Pochta'."]. Russkaia literatura, no. 2, 1958, pp. 136-141. (In Russ.)

Kotel'nikov, V. A. "I. A. Goncharov v tsenzurnom vedomstve" ["I. A. Goncharov in the Censorship Department”]. Tsenzura v Rossii: istoriia i sovremennost' [Censorship in Russia: History and Modernity], issue 6. St. Petersburg, Rossiiskaia natsional'naia biblioteka Publ., 2013, pp. 247-278. (In Russ.) 
Loshchits, Iu. M. Goncharov [Goncharov]. Moscow, Molodaia gvardiia Publ., 1977. 351 p. (In Russ.)

Mel'nik, V. I. I. A. Goncharov [I. A. Goncharov]. Moscow, Veche Publ., 2012. 432 p. (In Russ.)

Pyrkov, I. V. "Pis'ma Oblomova" [“Oblomov's Letters"]. Vestnik slavianskikh kul'tur, no. 3 (25), 2012, pp. 71-80. (In Russ.)

Semenova, T. A. "Osobennosti razvitiia gazetnogo dela v Rossii v pervoi polovine XIX veka" ["Features of the Development of Newspaper Business in Russia in the First Half of the $19^{\text {th }}$ Century"]. Molodoi uchenyi, no. 12 (23), 2010, pp. 24-27. (In Russ.)

Semenov, A. N. "Kontsept SMI v strukture khudozhestvennogo teksta I. A. Goncharova (roman 'Oblomov')" ["The Concept of Mass Media in the Structure of I. A. Goncharov's Literary Text (the Novel 'Oblomov')"]. Materialy V Mezhdunarodnoi nauchnoi konferentsii, posviashchennoi 200-letiiu so dnia rozhdeniia I. A. Goncharova [Proceedings of the $5^{\text {th }}$ International Scientific Conference Dedicated to the $200^{\text {th }}$ Anniversary of I. A. Goncharov]. Ul'ianovsk, Korporatsiia tekhnologii prodvizheniia Publ., 2012, pp. 144-151. (In Russ.)

Sukhikh, I. N. Problemy poetiki A. P. Chekhova [Issues of A. P. Chekhov's Poetics]. Leningrad, Leningradskii universitet Publ., 1987, 180 p. (In Russ.)

Truaia, Anri. "Mil'on terzanii" Ivana Aleksandrovicha Goncharova ["Million of Torments" by Ivan Alexandrovich Goncharov]. Moscow, Tsentr knigi Rudomino Publ., 2012, pp. 111-114. (In Russ.)

Fromm, Erikh. "Iskusstvo liubit"” ["The Art of Loving"]. Moscow, Pedagogika Publ., 1990. pp. 10-11. (In Russ.) 


\section{Роман-эксперимент Н. А. Некрасова и Ф. М. Достоевского в свете этнопоэтики}

Работа выполнена в рамках государственного задания Министерства науки и высмего образования Российской Федеращии (тема № 0856-2021-0005)

Аннотация: В статье рассматриваются романы Н. А. Некрасова «Жизнь и похождения Тихона Тростникова» (1843) и Ф. М. Достоевского «Униженные и оскорбленные» (1861) как экспериментальные, в которых писатели стремились соединить европейские и национальные традиции. Обращение к биографическому материалу, использование структурного метода позволило обнаружить сходство в жанровом содержании произведений и различие, обусловленное разными мировоззренческими установками писателей. Оба романа создавались как автобиографические, авантюрные и фельетонные, включали элементы «натурального очерка», но каждый из писателей стремился использовать национальное жанровое содержание: у Некрасова это народная драма, а Достоевский обращается к традициям древнерусской календарной словесности, проложной повести, в которой показывается проверка Священного Писания. Некрасову не удалось создать целостного произведения, во многом из-за повествовательной формы, в которой в некоторых случаях проступало пародийное начало. Но Достоевскому евангельские аллюзии и притчевый сюжет, а также задача «восстановления погибшего человека», обращения к церковному календарю позволяют вывести роман на новый уровень, высшей формой которого стали его последние произведения «Подросток» и «Братья Карамазовы».

Ключевые слова: Н. А. Некрасов, Ф. М. Достоевский, роман-фельетон, авантюрный роман, автобиографические аллюзии, притчевый сюжет, церковный календарь.

Информация об авторе: Елена Алексеевна Фёдорова, доктор филологических наук, доцент, профессор кафедры теории и практики коммуникации, Ярославский государственный университет им. П. Г. Демидова, ул. Советская, д. 14, 150003 г. Ярославль, Россия. ORCID ID: https://orcid.org/0000-0001-7756-2499

E-mail: sole11@yandex.ru

Дата поступления статьи в редакиию: 23.01 .2021

Дата одобрения статьи рецензентами: 16.03 .2021

Дата публикации статьи: 28.06.2021

Для ицитирования: Фёдорова Е. А. Роман-эксперимент Н. А. Некрасова и Ф. М. Достоевского в свете этнопоэтики // Два века русской классики. 2021. Т. 3, № 2. С. 138-149. https://doi.org/10.22455/2686-7494-2021-3-2-138-149 


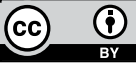

This is an open access article distributed under the Creative Commons Attribution 4.0 International (CC BY 4.0)
Dva veka russkoi klassiki,

vol. 3, no. 2, 2021, pp. 138-149. ISSN 2686-7494

Two centuries of the Russian classics, vol. 3, no. 2, 2021, pp. 138-149. ISSN 2686-7494

Research Article

(C) 2021. Elena A. Fedorova

P. G. Demidov Yaroslavl State University Yaroslavl, Russia

\section{Experimental Novels by Nikolay Nekrasov and Feodor Dostoevsky in the Light of Ethnopoetics}

Acknowledgments: The work was carried out within the framework of the state task of the Ministry of Science and Higher Education of the Russian Federation (topic No. 08562021-0005).

Abstract: The article considers novels The Life and Adventures of Tikhon Trostnikov (1843) by N. A. Nekrasov and Humiliated and Insulted (1861) by F. M. Dostoevsky as experimental works in which the authors sought to combine European and national traditions. The reference to biographical material, the use of the structural method allowed to discover the similarity in genre content of the works and the difference of ideological attitudes of the authors. Both novels were created as autobiographical works, adventurous and satiric, included elements of "natural essay", but each of the authors sought to use national genre content: Nekrasov's is a folk drama, and Dostoevsky refers to the traditions of Old Russian calendar literature, a literary story that shows the verification of the Holy Scriptures. Nekrasov failed to create a complete work, largely due to the narrative form, in which in some cases the parody begins to appear. But Dostoevsky managed to bring the novel to a new level, especially in his last works The Raw Youth and The Brothers Karamazov. Performing the task of "restoring the lost man", Dostoevsky turns to the church calendar, Gospel allusions and parable plot.

Keywords: N. A. Nekrasov, F. M. Dostoevsky, feuilleton novel, adventurous novel, autobiographical allusions, parable plot, church calendar.

Information about the author: Elena A. Fedorova, DSc in Philology, Associate Professor, Professor for the Department of Theory and Practice of Communication, P. G. Demidov Yaroslavl State University, Sovetskaya St., 14, 150003 Yaroslavl, Russia. ORCID ID: https://orcid.org/0000-0001-7756-2499

E-mail: sole11@yandex.ru

Received: January 23, 2021

Approved after reviewing: March 16, 2021

Published: June 28, 2021

For citation: Fedorova, E. A. "Experimental Novels by Nikolay Nekrasov and Feodor Dostoevsky in the Light of Ethnopoetics." Dva veka russkoi klassiki, vol. 3, no. 2, 2021, pp. 138-149. (In Russ.) https://doi.org/10.22455/2686-7494-2021-3-2-138-149 
Несмотря на все возрастающий интерес во всем мире к творчеству Ф. М. Достоевского и попытки рассмотреть взаимовлияния русских писателей [Gerigk], православную основу творчества Достоевского [Gibson; Müller], мало внимания в зарубежной и даже отечественной науке уделено новаторскому по сути роману «Униженные и оскорбленные» (1861), раскрытию национального жанрового содержания этого произведения [Egeberg]. Продуктивным в этом плане видится нам сопоставление указанного романа с незавершенным произведением Н. А. Некрасова «Жизнь и похождения Тихона Тростникова» (18431848). Петербургские типы Некрасова и Достоевского уже сравнивались ранее, было обнаружено очевидное их сходство [Фёдорова]. Чем это объясняется?

В 40-60-е гг. XIX в. русские писатели ищут новые жанровые формы, которые смогли бы вместить в себя охват современной действительности и одновременно воздействовали бы на широкую аудиторию. Стремление наполнить эти жанровые формы национальным содержанием объясняется подъемом самосознания, размышлением писателей о судьбе России в переломный момент ее истории. К таким новаторским произведениям можно отнести незаконченный роман Некрасова «Жизнь и похождения Тихона Тростникова» и роман Достоевского «Униженные и оскорбленные». Несмотря на дистанцию во времени создания этих произведений, между ними обнаруживается сходство.

Объединяет романы Некрасова и Достоевского автобиографический характер рассказчика, включение в них сцен из литературной и журналисткой жизни, ориентация на «фельетонный» и авантюрный западноевропейский роман, следование традициям «натурального очерка», гоголевские традиции. Можно утверждать, что романы вбирают в себя автобиографическое произведение, «натуральный очерк», роман-фельетон и авантюрный роман. Вместе с тем оба писателя стре- 
мятся обратиться к национальной почве: Некрасов пытается включить в роман историю Параши и ее брата-извозчика, их встречу в трактире (элементы народной драмы), а Достоевский ставит перед собой задачи, связанные с традициями дидактической древнерусской словесности. «Униженные и оскорбленные» вырастает из романа воспитания, содержит притчевый сюжет и евангельские аллюзии, а также ориентацию на церковный календарь.

В. Н. Захаров определил жанровую форму произведения «Униженные и оскорбленные» как «фельетонный роман», поскольку его содержание занимательно и актуально, в нем есть интрига, «петербургские тайны» обитателей дворцов и трущоб [Захаров 2013: 196]. В романе Некрасова также показана жизнь петербургского дна. Особенно тяготеет к «натуральному очерку» глава «Петербургские углы» [Шпилевая: 108]. Возможно, фактическая основа произведений обоих писателей создавалась на материале знаменитой Вяземской лавры в Петербурге, где преобладали питейные и публичные дома, воровские притоны [Юркова]. Главный герой романа Некрасова, Тихон, поселяется в подобных трущобах и знакомится с людьми «дна». Параша и Агаша - девушки, оказавшиеся без родных и помощи в большом чужом городе, - могут погибнуть или стать жертвой сладострастников [Некрасов: 163-164, 260]. Подобная судьба не исключена и для героини Достоевского Нелли, которая оказывается в публичном доме Бубновой, откуда ей помогает бежать Иван Петрович. Прообразом для обеих героинь становится Матильда из одноименного романа Э. Сю: у Некрасова это знаковое имя одной из падших героинь в романе о Тихоне Тростникове, известно также, что Достоевский мечтал перевести роман «Матильда» Э. Сю на русский язык. Мотив немецкой песни «Мой милый Августин» звучит в кондитерской, где сидит старик Смит (позднее он войдет в роман «Бесы») и является для Достоевского символом сентиментальной мещанской пошлости [Достоевский: 51, 863]. У Некрасова “Mein lieber Augustin” звучит в главе «Петербургские углы» и становится фоном для типичной картины петербургской жизни, поскольку об этом произведении сообщается, как «немецкой песенке, которую очень любят все петербургские немки» [Некрасов: 117].

Г. А. Шпилевая определила роман Некрасова как авантюрный и подчеркнула преимущества этого жанра: использование нероманных 
приемов - «нанизывание» сюжетно-однотипных событий, которые складывались в достаточно плоскую картину, имитирующие «эпическую объемность», «введение “вставных” новелл, меняющих стиль и расширяющих хронотоп повествования», изображение действительности «невероятно интересной и опасной», обращение к теме искусства [Шпилевая: 104, 109]. Исследовательница сопоставляет героя романа Некрасова «седого господина» с Хромым Бесом Луиса Велеса де Гевары на основании вопроса, который задает рассказчик: «...недоставало только для полной его биографии свидетельства о крещении. Но кто же усомнится, что хозяин крещеный?..» [Шпилевая: 105]. Кроме того, Г. А. Шпилевая обнаруживает в романе Некрасова и в романе Лесажа интертекстуальную «тонкую интеллектуальную игру между авторами, героем и современным читателем, которые достаточно иронично относились к обществу и литературе» [Шпилевая: 109].

Н. Н. Мостовская поднимает проблему пародии в романе: сюжетная линия Матильда - Тростников пародирует традиционный романтический роман, название второй части также пародийно, поскольку в ней говорится не о "русском Жильблазе», а показывается литературно-журнальная жизнь 1840-х гг. [Мостовская 1988: 55]. В главе «Почтеннейший» Некрасов создает заостренно сатирический портрет, опираясь на известные факты литературной и житейской биографии Булгарина, отзывы о нем в критике, обращаясь к методу доведения до абсурда мотивов, подлежавших осмеянию, нередко к гротеску, к сатире «на лица», используя отдельные элементы самого пародируемого стиля [Мостовская 1988: 56, 57]. Н. Н. Мостовская также отмечает гоголевские традиции, которые использует Некрасов в романе: это, прежде всего, лирические обращения к читателям, которые сочетаются с сатирическими обобщениями, бытовыми и гротескными зарисовками [Мостовская 1988: 26]. Исследовательница выделяет общие темы в лирических размышлениях Гоголя и Некрасова: образ Петербурга, пронизанный лирическим и сатирическим пафосом, а также размышления о литературном творчестве как общественном служении [Мостовская 1983: 26-27].

Создавая образ Петербурга, Некрасов делится своими первыми впечатления о «великолепном и обширном городе». И лишь после того, как пришлось спуститься в «душные подвалы» и увидеть там 
грустные сцены из жизни бедных людей, автор при обращении к городу отказался от своего первого впечатления: «И сильней поразили меня такие картины, неизбежные в больших и кипящих народонаселением городах, глубже запали в душу, чем блеск и богатства твои, обманчивый Петербург! И не веселят уже меня твои гордые здания и все, что есть в тебе блестящего и поразительного!» [Некрасов: 251].

Достоевский также создает образ призрачного Петербурга. Ихменев указывает Ивану Петровичу «на туманную перспективу улицы, освещенную слабо мерцающими в сырой мгле фонарями, на грязные дома, на сверкающие от сырости плиты тротуаров, на угрюмых, сердитых и промокших прохожих, на всю эту картину, которую обхватывал черный, как будто залитый тушью купол петербургского неба. Мы выходили уж на площадь; перед нами во мраке вставал памятник, освещенный снизу газовыми рожками, и еще далее подымалась тёмная, огромная масса Исакия, неясно отделявшаяся от мрачного колорита неба» [Достоевский 2000: 103]. Герой Достоевского, как и герой Некрасова, оказывается втянут в литературно-общественную борьбу, но от пародии писатель уходит. Можно увидеть немногие приемы антифразиса, например, в случае, когда газета «Северная пчела» (где печатались литературные враги Достоевского Ф. В. Булгарин и Л. В. Брант) в тексте Достоевского превращается в «Северный трутень» [Достоевский 2000: 76].

С одной стороны, Достоевский искал приемы привлечения внимания читателя, как это происходит в бульварном романе. Образцом может служить роман Э. Сю «Парижские тайны», который упоминает Маслобоев в романе: это остросюжетность, любовные треугольники, детективная история, семейная тайна [Захаров 2013: 183-185]. Однако, несмотря на эту близость, Достоевский ставил совершенно иные задачи в своем романе, поэтому его главных героев нельзя назвать «застывшими типами бульварного романа» [Шарипова: 186].

Во время встречи в Твери в августе 1859 г. Достоевский рассказал брату Михаилу о замысле нового романа. Вернувшись в Петербург, М. М. Достоевский высказал в письме от 21 сентября 1859 г. свои мысли о двух новых романах: «Милейший мой, я, может быть, ошибаюсь, но твои два большие романа будут нечто вроде "Lehrjahre und 
Wanderungen” Вильгельма Мейстера. Пусть же они и пишутся, как писался “Вильгельм Мейстер”, отрывками, исподволь, годами. Тогда они и выйдут так же хороши, как и два Гетевы романа <...>. Мне бы очень хотелось, чтоб в Твери ты написал что-нибудь хорошее, из ряду вон» [Долинин: 515]. А. С. Долинин увидел общее между романом Гёте и Достоевского: автобиографичность главного героя, основную идеологическую концепцию - отказ от эгоистически индивидуального в пользу социальности, сходство между образом Миньоны у Гёте и Нелли у Достоевского [Долинин: 561]. Некрасов на полях автографа романа о Тихоне Тростникове делает отметку, обращаясь к другому роману Гёте - «Страдания молодого Вертера» [Некрасов: 750].

Роман воспитания И. В. Гёте «Годы странствий Вильгельма Мейстера» показывал духовное возрастание души героя, его освобождение от эгоизма. Значительную роль в этом сыграли героини этого произведения - Миньона и Наталья. Роман Достоевского «Униженные и оскорбленные» несет в себе элементы романа воспитания: история Наташи зеркально отражает судьбу матери Нелли, рассказ Нелли отцу Наташи о гибели матери от жестокости отца, который не нашел в себе силы при жизни дочери простить ее, становится предупреждением для Николая Сергеевича Ихменева, отца Наташи. Введение церковного календаря в роман превращает его в воспитательное чтение, которое напоминает Четьи-Минеи: начинается действие в сентябре, накануне праздника Воздвижения Животворящего Креста, а завершается в Светлое Христово Воскресение примирением отца и дочери. Кроме того, истории Наташи и матери Нелли - это две вариации на один евангельский сюжет - притчи о блудном сыне. Притчевый сюжет продолжает традиции дидактической проложной повести древнерусской словесности, повести о проверки Писания [Ромодановская: 71-73].

Основная тема в романе - христианская: «Она обозначена в датах христианского календаря (кульминация событий приурочена к Пасхе), в присутствии Евангелия в тексте романа, в имени Христа, в идеале и идеях героев, в христианском преображении традиционных романных мотивов «разбитых сердец», «несбывшихся надежд», «неустроенных судеб». В страданиях яснеет Истина» [Захаров: 2013, 199200]. Кроме того, Достоевский вводит в роман пасхальный рассказ историю Нелли [Захаров 2012: 121-122]. Симметричная композиция 
романа (история матери Нелли и судьба Наташи), притчевый сюжет, обращение к церковному календарю, аллюзии к Евангелию на идейном и сюжетном уровнях продолжают традиции проложной повести древнерусской словесности, в которой происходила проверка Священного Писания. Новые типы героев, символика хронотопа и предметной детали, передача авторских идей своим героям, некоторые сюжетные ходы затем будут использованы Достоевским в своем «великом пятикнижии».

Роман призван утвердить идею христианской любви к ближнему: забывает о своем чувстве Иван Петрович, погружаясь в сопереживание Наташе, отказывается от гордости Ихменев, даруя прощение своей «блудной дочери» в Светлое Христово Воскресение. Помогает ему в этом рассказ Нелли, которая выполняет просьбу Ивана Петровича. Иван Петрович, как Мышкин, страдает за Наташу до боли в сердце: «Я действительно почувствовал, что меня как будто что ударило в самое сердце» [Достоевский 2000: 201]. Система образов в романе выстраивается не по принципу положительных и отрицательных персонажей, а по способности героев к любви и прощению. Николай Сергеевич Ихменев не только прощает свою дочь в Светлое Христово Воскресение, но, подобно будущему герою, Мармеладову, стремится возвысить свою униженную дочь, вспоминая евангельский сюжет «Христос и грешница»: «О! Пусть мы униженные, пусть мы оскорбленные, но мы опять вместе и пусть, пусть теперь торжествуют эти гордые и надменные, унизившие и оскорбившие нас! Пусть они бросят в нас камень! Не бойся, Наташа... Мы пойдем рука в руку, и я скажу им: это моя дорогая, это возлюбленная дочь моя, это безгрешная дочь моя, которую вы оскорбили и унизили, но которую я, я люблю, и которую благословляю во веки веков!» [Достоевский 2000: 378].

Таким образом, вбирая элементы европейского романа (автобиографического, авантюрного, фельетонного), романы Некрасова и Достоевского обращаются к национальному жанровому содержанию, но если для Некрасова это народная драма, то Достоевский берет за основу проложную повесть, которая «проверяет» Священное Писание, обращаясь к частным судьбам людей. Идея духовного воскресения человека, пасхальность русской словесности помогает Достоевскому создать первый удачный роман, который восторженно принимается читателями. Некра- 
совскому роману подобной «духовной скрепы» не хватает, поэтому он сюжетно и стилистически рассыпается и остается незавершенным.

\section{Список литературы \\ Источники}

Достоевский Ф. М. Полн. собр. соч. Канонические тексты. Петрозаводск: Издво Петрозаводского ун-та, 2000. T. IV. 955 с.

Долинин А. С. Письма М. М. Достоевского к Ф. М. Достоевскому // Ф. М. Достоевский: Материалы и исследования. Л.: Изд-во АН СССР, 1935. С. 505-555.

Некрасов Н. А. Полн. собр. соч. и писем: в 15 т. Л.: Наука; Ленинградское отд-е, 1984. Т. 8: Художественная проза. Незаконченные романы и повести 1841-1856 гг. $782 \mathrm{c}$.

\section{Исследования}

Буданова Н. Ф. «Униженные и оскорбленные» // Достоевский: Сочинения, письма, документы: Словарь-справочник / сост. и науч. ред. Г. К. Щенников, Б. Н. Тихомиров. СПБ.: Пушкинский Дом, 2008. С. 181-185.

Захаров В. Н. Имя автора - Достоевский. Очерк творчества. М.: Индрик, 2013. $456 \mathrm{c}$.

Захаров В. Н. Проблемы исторической поэтики. Этиологические аспекты. М.: Индрик, 2012. 264 с.

Мостовская Н. Н. Гоголь в восприятии Некрасова // Некрасовский сборник. Л.: Наука, Ленинградское отд-е, 1983. T. VIII. С. 25-35.

Мостовская Н. Н. Пародия в прозе Некрасова (сатирическое мастерство; полемика) // Некрасовский сборник. Л.: Наука, Ленинградское отд-е, 1988. Т. IX. C. 54-68.

Ромодановская Е. К. От цитаты к сюжету. Роль повести-притчи в становлении новой русской литературы // Евангельский текст в русской литературе XVIIIXX веков. Цитата, реминисценция, мотив, сюжет, жанр. Петрозаводск: Изд-во Петрозаводского ун-та, 1994. С. 66-75.

Фёдорова Е. А. Петербургские типы в прозе Н. А. Некрасова и в романе Ф. М. Достоевского «Преступление и наказание» // MUNDO ESLAVO - JOURNAL OF SLAVIC STUDIES. 2017. № 16. C. 93-98.

Шарипова Д. Д. О влиянии жанра бульварного романа на творчество Ф. М. Достоевского: «Братья Карамазовы» // Достоевский и современность. Материалы XXXI Международных Старорусских чтений 2016 года. Великий Новгород, 2017. C. $182-190$.

Шпилевая Г. А. «Жизнь и похождения Тихона Тростникова» и традиции авантюрного романа // Некрасовский сборник. Л.: Наука, Ленинградское отд-е, 2008. T. XIV. C. 103-111.

Юркова 3. М. Сенная площадь. Вчера, сегодня, завтра. Центрполиграф, 2011. 272 c. 
Egeberg Erk. Na poroge masterstva: Ot "Unizhennykh i oskorblennykh" k "Prestupleniiu I nakazaniiu" // Dostoevsky Studies: The Journal of the International Dostoevsky Society n.s. 20 (2016): 47-58.

Gerigk H.-J. Ein Meister aus Russland. Beziehungsfelder der Wirkung Dostojewskijs. Vierzehn Essays. Heidelberg: Universitätsverlag Winter, 2010. 215 s.

Gibson A. Boyce. The Religion of Dostoevsky. Eugene, OR: Wipf\&Stock, 2016. 224 p.

Müller L. Die Begegnung und Auseinandersetzung von östlichem und westlichem Christentum im Leben und Werk Dostojewskijs, Tolstojs und Solov'evs // Tausend Jahre Christentum in Russland. Zum Millennium der Taufe der Kiever Rus / Hrsg. K. C. Felmy, G. Kretschmar, F. von Lilienfeld, C.-J. Roepke, Göttingen: Vandenhoeck \& Ruprecht, 1988, pp. 78-82. 


\section{References}

Budanova, N. F. "Unizhennye i oskorblennye" ["Humiliated and Insulted"]. Dostoevskii: Sochineniya, pis'ma, dokumenty [Dostoevsky: Works, Letters, Documents]. St. Petersburg, Pushkinskii Dom Publ., 2008, pp. 181-185. (In Russ.)

Zakharov, V. N. Imya avtora - Dostoevskii [The Author's Name is Dostoevsky]. Moscow, Indrik Publ., 2013. 456 p. (In Russ.)

Zakharov, V.N. Problemy istoricheskoi poetiki [Issues of Historical Poetics]. Moscow, Indrik Publ., 2012. 264 p. (In Russ.)

Mostovskaya, N. N. "Gogol' v vospriiatii Nekrasova" ["Gogol as Perceived by Nekrasov"]. Nekrasovskii sbornik [Nekrasov Collection], vol. VIII. Leningrad, Nauka Publ., 1983, pp. 25-35. (In Russ.)

Mostovskaya, N. N. "Parodiia v proze Nekrasova (satiricheskoe masterstvo; polemika)" ["Parody in Nekrasov's Prose (Satirical Skill; Polemics)"]. Nekrasovskii sbornik [Nekrasov Collection], vol. IX. Leningrad, Nauka Publ., 1988, pp. 54-68. (In Russ.)

Romodanovskaya, E. K. “Ot tsitaty k siuzhetu. Rol' povesti-pritchi v stanovlenii novoi russkoi literatury" ["From Quotation to Plot. The Role of Story-Parable in the Formation of New Russian Literature"]. Evangel'skii tekst v russkoi literature XVIII-XX vekov [The Gospel Text in Russian Literature of the $18^{\text {th }}-20^{\text {th }}$ Centuries], collection of scientific papers. Petrozavodsk, Izdatel'stvo Petrozavodskogo universiteta Publ., 1994, pp. 66-75. (In Russ.)

Fedorova, E. A. "Peterburgskie tipy v proze N. A. Nekrasova i v romane F. M. Dostoevskogo 'Prestuplenie i nakazanie"' [“Petersburg Types in N. A. Nekrasov's Prose and in the Novel 'Crime and Punishment' by F. M. Dostoevsky"]. Mundo eslavo journal of slavic studies, no. 16, 2017, pp. 93-98. (In Russ.)

Sharipova, D. D. "O vliianii zhanra bul'varnogo romana na tvorchestvo F. M. Dostoevskogo: 'Brat'ia Karamazovy"' ['On the Influence of the Pulp Fiction on F. M. Dostoevsky's Works: 'The Brothers Karamazov.']. Dostoevskii i sovremennost'. Materialy XXXI Mezhdunarodnykh Starorusskikh chtenii 2016 goda [Dostoevsky and the Present. Materials of the $31^{\text {st }}$ International Old Russian Proceedings 2016]. Veliky Novgorod, Novgorodskii muzei-zapovednik Publ., 2017, pp. 182-190. (In Russ.)

Shpilevaya, G. A. “'Zhizn' i pokhozhdeniia Tikhona Trostnikova' i traditsii avantiurnogo romana" [“The Life and Adventures of Tikhon Trostnikov' and the Traditions of the Adventure Novel"]. Nekrasovskii sbornik [Nekrasov Collection], vol. XIV, Leningrad, Nauka Publ., 2008, pp. 103-111. (In Russ.)

Yurkova, Z. M. Sennaya ploshchad'. Vchera, segodnya, zavtra [Sennaya Square. Yesterday, Today, Tomorrow]. Tsentrpoligraf Publ., 2011. 272 p. (In Russ.)

Egeberg, Erk. Na poroge masterstva: Ot "Unizhennykh i oskorblennykh" $\mathrm{k}$ "Prestupleniiu I nakazaniiu". Dostoevsky Studies: The Journal of the International Dostoevsky Society, no. 20, 2016, pp. 47-58. (In Russ.)

Gerigk, H.-J. Ein Meister aus Russland. Beziehungsfelder der Wirkung Dostojewskijs. Vierzehn Essays. Heidelberg, Universitätsverlag Winter, 2010. 215 S. (In German).

Gibson, A. Boyce. The Religion of Dostoevsky. Eugene, OR: Wipf\&Stock, 2016. 224 p. (In English). 
Е. А. Фёдорова. Роман-эксперимент Н. А. Некрасова и Ф. М. Достоевского в свете ...

Müller, L. Die Begegnung und Auseinandersetzung von östlichem und westlichem Christentum im Leben und Werk Dostojewskijs, Tolstojs und Solovevs. Tausend Jahre Christentum in Russland. Zum Millennium der Taufe der Kiever Rus, Hrsg. K. C. Felmy, G. Kretschmar, F. von Lilienfeld, C.-J. Roepke, Göttingen, Vandenhoeck \& Ruprecht, 1988, S. 78-82. (In German). 


\title{
«Аскетическая философия» К. Н. Леонтьева: тезаурус и контекст
}

\begin{abstract}
Аннотация: Целостное и пристальное изучение публицистики, художественных произведений и писем К. Н. Леонтьева позволяет автору статьи показать, как формировались воззрения писателя, обозначенные им в конце жизни словами «моя аскетическая философия», в каком контексте существовал и как менялся его словарь. В работе отмечается писательский, философский и личностный интерес Леонтьева к вопросам жизни духа, динамика его взглядов, показывается, как в 1860-е гг. от эстетического интереса к Церкви и политической ее защиты на консульских постах Леонтьев приходит к жажде веры. Особое внимание автором уделяется идее и концепту послушания, которые связаны с леонтьевской идеей «трансцендентного эгоизма», сосредоточенности на личном спасении. За идеей послушания стоит у Леонтьева мысль о самопонуждении. Писатель и мыслитель наглядно объясняет взаимообусловленность двух начал, «мира» и «монастыря», синонимом православной культуры становится для Леонтьева культура монастырская. Аскетические принципы дисциплины и «трезвения» Леонтьев старался вносить и в собственное художественное творчество, причем не только в содержание, но и в «исполнение», применяя на практике те правила, которые сформулировал позднее в своей знаменитой статье «Анализ, стиль и веяние».
\end{abstract}

Ключевье слова: К. Н. Леонтьев, русская литература, философия, христианская аскетика, послушание, мораль.

Информация об авторе: Ольга Леонидовна Фетисенко, доктор филологических наук, ведущий научный сотрудник, Институт русской литературы (Пушкинский Дом) Российской академии наук, наб. Макарова, д. 4, 199034 г. Санкт-Петербург, Россия. ORCID ID: https://orcid.org/0000-002-5670-2656

E-mail: betsy98@mail.ru

Дата поступления статьи в редакиию: 19.02.2021

Дата одобрения статьи рецензентами: 11.04.2021

Дата публикации статьи: 28.06.2021

Для иитирования: Фетисенко О. Л. «Аскетическая философия» К. Н. Леонтьева: тезаурус и контекст // Два века русской классики. 2021. Т. 3, № 2. С. 150-167. https://doi.org/10.22455/2686-7494-2021-3-2-150-167 


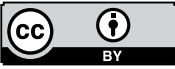

This is an open access article distributed under the Creative Commons Attribution 4.0 International (CC BY 4.0)
Dva veka russkoi klassiki, vol. 3, no. 2, 2021, pp. 150-167. ISSN 2686-7494 Two centuries of the Russian classics, vol. 3, no. 2, 2021, pp. 150-167. ISSN 2686-7494

Research Article

(c) 2021. Olga L. Fetisenko

Institute of Russian Literature (Pushkin House) of the Russian Academy of Sciences

St. Petersburg, Russia

\title{
Konstantin Leontiev's “Ascetic Philosophy": Thesaurus and Context
}

\begin{abstract}
A holistic and close study of journalism, works of art and letters of K. N. Leontiev allows the author of the article to show the formation of the writer's views, designated by him at the end of his life with the words "my ascetic philosophy", the context they existed in and his vocabulary changes. The work discusses Leontiev's creative, philosophical and personal interest to the issues of life of the spirit, the dynamics of his views, it is shown, how in the 1860s Leontiev comes from an aesthetic interest in the Church and its political defense in consular posts to a thirst for faith. The author pays special attention to the idea and concept of obedience, which are associated with Leontiev's idea of "transcendental egoism", focusing on personal salvation. Behind the idea of obedience, Leontiev thinks about self-condemnation. The writer and thinker clearly explains the interdependence and interdependence of two principles, the "world" and the "monastery"; for Leontiev, monastery culture becomes a synonym for Orthodox culture. Leontiev tried to introduce ascetic principles of discipline and "sobriety" into his own artistic creation, and not only into content, but also into "performance", applying in practice the rules that he formulated later in his famous article Analysis, Style and Trends.

Keywords: Konstantin Leontiev, Russian literature, philosophy, Christian asceticism, obedience, morality.
\end{abstract}

Information about the author: Olga L. Fetisenko, DSc in Philology, Leading Research Fellow, Institute of Russian Literature (Pushkin House) of the Russian Academy of Sciences, nab. Makarova St. 4, 199034 St. Petersburg, Russia.

ORCID ID: https://orcid.org/0000-002-5670-2656

E-mail: betsy98@mail.ru

Received: February 19, 2021

Approved after reviewing: April 11, 2021

Published: June 28, 2021

For citation: Fetisenko, O. L. "Konstantin Leontiev's 'Ascetic Philosophy': Thesaurus and Context." Dva veka russkoi klassiki, vol. 3, no. 2, 2021, pp. 150-167. (In Russ.) https://doi.org/10.22455/2686-7494-2021-3-2-150-167 
В 2021 г. отмечается двойной юбилей писателя и мыслителя Константина Николаевича Леонтьева (1831-1891), которого Л. Н. Толстой считал стоящим «головой выше всех русских философов» [Маковицкий: 352]. Но были ли воззрения Леонтьева системны? Можно ли говорить о созданном им философском направлении? Если считать, что в России вообще не было «философии» в европейском понимании этого слова, то, конечно же, нет. Если вписать Леонтьева в традицию «иррационализма», «антирационализма», «органической философии»', то некая упорядоченность возникнет. Но Леонтьев как был, по его выражению, «славянофилом на свой салтык» [Леонтьев 12, кн. 2: 72], так и далее повергал рациональный ум в растерянность: на какую же «полку» его ставить $^{2}$. Однако в последнее десятилетие своей жизни Леонтьев все же системен и даже пытается создать что-то вроде своей философской школы с избранными учениками, кружком «гептастилистов» ${ }^{3}$. Шутливые термины «собственный умственный обиход» [Леонтьев 8, кн. 2: 23], «мое домашнее для собственного употребления Богословие» [Преемство от отцов: 276$]^{4}$ скрывают четко продуманную систему взглядов. Леонтьев видит себя именно философом: «...а я ведь на “мудрость” немножко претендую...»; «...у меня свое учение...» [Преемство от отцов: $261,282]$. Это цитаты из огромного письма-трактата (от 19 января 1 февраля 1891 г.), адресованного священнику Иосифу Фуделю, одному из учеников мыслителя. И само выражение «аскетическая философия», точно передающее суть леонтьевского мировоззрения, взято тоже из письма к О. А. Новиковой [Леонтьев 12, кн. 2: 522]. Сам способ мышления у Леонтьева именно философский, хотя он и говорил, что «картины жизни» ему милее «отвлеченных начал» [Леонтьев 8, кн. 2: 136].

1 См., например: [Авдеева; Носов; Океанский].

2 Там же.

3 См. посвященную этой теме монографию: [Фетисенко 2012].

4 Здесь и далее курсив в цитатах - авторский. 
По этому поводу можно вспомнить еще одно его шутливое признание: Леонтьев, перефразируя Гоголя, говорит, что вместо писания статьи в газету, он лучше бы поразмыслил, «отчего слон не родится в скорлупе» [Леонтьев 12, кн. 2: 234].

Особый интерес у Леонтьева с юности вызывали науки о человеке социальная психология, «физиологии обществ» [Леонтьев 2: 325], физиогномика, краниоскопия. Связующим звеном всех научных дисциплин он считал антропологию, задачей которой полагал необходимость «уловить соотношение формы с духовным содержанием» [Леонтьев 7, кн. 2: 307]. Интересом к изучению человека (и целых наций и культур) в их динамике был вызван задуманный в 1871 г. научный труд «Прогресс и развитие», разделившийся на несколько отдельных работ, самая известная из которых - «Византизм и Славянство». Это год духовного перелома Леонтьева, обращения в «личное Православие», последовавшего после чудесного исцеления от тяжелой болезни. Естественно, в то же время обновляются и его понятийный аппарат, и сам «словарь» ${ }^{1}$.

Интерес к вопросам жизни духа у Леонтьева троякий - писательский, философский и, с определенного времени, с прирастанием собственного опыта ${ }^{2}$, еще и собственно человеческий. Леонтьев, конечно, не единственный русский писатель и мыслитель, задумавшийся о смысле подвижничества (аскетизма) ${ }^{3}$, но его особенность в том, что свои представления об аскезе он распространяет на всё вокруг - на государственную жизнь, культуру, просвещение, философию и т. д. (В подобном универсализме ему близок Вл. С. Соловьев). В небольшой статье трудно коснуться всего объема «аскетическо-философских» воззрений писателя, сосредоточимся на наиболее важных вопросах.

\footnotetext{
${ }^{1}$ Однако обновляется не настолько, чтобы совсем не узнать в нем Леонтьева, каким он был до обращения. Справедливо суждение Р. Гольдта: «...нельзя провести четкую грань между Леонтьевым-мыслителем до и после чудесного спасения <...>. Оно, правда, привело к перелому в его “жизнестроительстве” в смысле античной “заботы о себе”, но не в его мировоззрении. Болезнь лишь выплеснула на поверхность скрытые под страстями жизни залежи духовности» [Гольдт: 137].

${ }^{2}$ Ср. в указанной выше глубокой статье немецкого исследователя: «... леонтьевское употребление термина “Страх Божий” основано не на богословских соображениях, а на сугубо индивидуальном опыте» [Гольдт: 136].

${ }^{3}$ См. об этом: [Котельников].
} 
Одним из них является смысловое развитие отношения Леонтьева к понятию «мораль». Исследователи, говоря о раннем Леонтьеве, выбирают между терминами «аморализм» или «имморализм» ${ }^{1}$. Н. А. Бердяев в предисловии к французскому изданию своей книги о Леонтьеве предложил, быть может, более точный термин: «псевдо-аморализм» [Berdiaeff: 8].

Вот автобиографическое признание в романе «Две избранницы»: «Хотя он $<\ldots>$ Церковь Православную и чтил, и любил, и защищать ее был готов $\langle\ldots\rangle$, но у него, как и у многих людей, была при этом своя личная моральная казуистика...» [Леонтьев 5: 78]. Подразумевается свой кодекс, круг понятий о том, что допустимо, а что нет (по эстетическому критерию, поэтому свои нравственные воззрения тех лет Леонтьев позднее называл «эстетическим деизмом» или «эстетическим морализмом»). Например, разврат недопустим, но «жорж-зандизм» [Леонтьев 6, кн. 1: 622], «поэзия изящной безнравственности» [12, кн. 1: 364] вполне приветствуется, были бы только верность красоте и честность перед собою. Ср. в романе «Египетский голубь»: «...в Бога я верил пламенно $<\ldots>$ Церковь Православную я чтил $<\ldots>$ но я любил ее больше русским и поэтическим чувством, чем духовным или нравственным. <...> всею моею нравственною жизнью тогда руководило не учение Православия и не заповеди Божии, а кодекс моей собственной гордости, система моей произвольной морали, иногда, быть может, и благородной, но нередко в высшей степени безнравственной» [Леонтьев 5: 294-295].

Доля «моральной казуистики» не оставит Леонтьева и после обращения. Сравним его различение безусловно необходимого смирения перед Церковью и необязательного смирения перед человеком, если это твой идейный противник [Леонтьев 6, кн. 1: 238].

Подобно некоторым своим героям, молодой Леонтьев - «безнравственный» и добрый. Его живит «чистое пламя любви и человечности» [Леонтьев 2: 15]. Его девиз: «Надо уметь быть счастливым!» [Леонтьев 5: 161]. «Я полюбил жизнь со всеми ее противоречиями, непримиримыми вовеки, и стал считать почти священнодействием мое страстное

\footnotetext{
${ }^{1}$ См., например: [Коковкина; Океанский; Репников]. «Поздний» или зрелый Леонтьев позволяет современной исследовательнице взглянуть на него как на «моралиста» и даже предложить термин «эсхатологическая этика Леонтьева» [Журавлева].
} 
участие в этой живописной драме земного бытия...» [Леонтьев 5: 299]; «...я едва-едва стал выходить тогда из какого-то красивого, но неясного пантеистического тумана, в котором долго жил, безнравственно и весело...» [Леонтьев 8, кн. 1: 429]. Господствующее чувство в то время - самодовольство: «душевное comme il faut» [Леонтьев 2: 168]. Однако и суд над собой был ему не чужд, как и понимание духовной красоты «отречения». Об этом свидетельствует роман «Подлипки» (1861) и тема святого Мартиниана (тема отшельничества, бегства от мира) в романе «В своем краю» (опубл. в 1864).

В 1860-е гг. от эстетического интереса к Церкви и политической ее защиты на консульских постах Леонтьев приходит к жажде веры. «Если сильная вера в Церковь <...> усиливает любовь к ближнему, к Православной родине, к семье, то любовь к Церкви $<\ldots>$ рано или поздно - может привести к вере. Захочется жить и руководиться тем, что так нравится» [Леонтьев 8, кн. 1: 398]. Сравним со словами о главной героине романа «Подруги» (1889), которая желает верить и хочет, «чтобы ей доказали, что Христос есть Бог, что он тот самый Бог, от которого зависит ее счастие и несч<астие>, ее будущее, ее покой и ее радость...» [Леонтьев 5: 562]. Таким же путем и Леонтьев подошел к своему обращению.

Можно отметить еще одну деталь. Идея «послушания», которая, как мы увидим, станет доминирующей у позднего Леонтьева, изначально не противоречила его характеру. Он - послушный сын ${ }^{1}$, он вносил «поэзию послушания» в свою службу: «...и в чиновничестве есть своя поэзия - но она должна состоять в порядке, в послушании и точности» [Леонтьев 5: 414]. Интересен чисто монашеский опыт послушания Леонтьева в быту (он часто спрашивает советов у друзей, проверяя свои решения) и даже - в конце жизни - послушания, оказываемого младшему по возрасту и положению. Стоит отметить и его шутливое, но истинно монастырское обращение к прислуге и воспитаннице Варе Прониной, приведенное в письме к о. И. Фуделю: «Варюша $<\ldots>$ благослови, кому мне прежде писать: Фуделю $<\ldots>$ или $<\ldots>$ Страхову $<\ldots>$ Разреши-ко ты?» [Преемство от отцов: 262-263]. Самого себя Леонтьев любил называть «катехизатором» (и, в общем, имел основания, потому что нередко и бывал таковым - по благословению своего старца Амвросия Оптинского).

${ }^{1}$ О его отношениях с матерью см.: [Фетисенко 2020]. 
Леонтьев, однако, не превратился в «моралиста» в расхожем понимании. Если он и употребляет слово «мораль», то исключительно в отрицательном контексте (борясь против «чистой морали», автономной от Бога). Его терминология - это «грех» и «добродетель», «внутреннее устроение» человека и т. д., т. е. терминология христианской антропологии и христианской аскетики. И здесь мы подходим к теме контекста, фактически совпадающего с кругом чтения Леонтьева, который был с 1871 г. чисто монашеским ${ }^{1}$. Это Новый Завет, Псалтырь, пророческие книги Ветхого Завета и отцы-аскеты - Авва Дорофей, Иоанн Лествичник, Авва Исаак Сирин и другие (подчас такие редкие, как, например, Иоанн Карпафийский). Знал он и творения своего современника, «мыслящего аскета» [Леонтьев 8, кн. 1: 451] Феофана Затворника. В публицистике Леонтьева нередки ссылки на св. Иоанна Златоуста или Блаженного Августина. Догматическое богословие его интересовало значительно меньше ${ }^{2}$. К области «контекста» «аскетической философии» Леонтьева следует отнести также устное предание, например, монашеские присловия, которые он любил употреблять («Бог и я...» - в значении: «думай не о чужих грехах, а о своих, о своем спасении»; «свят, да не искусен»; «У Бога путей много» и др.) [Леонтьев 8, кн. 1: 417, 429; 12, кн. 2: 51, 65, 360; Преемство от отцов: 279].

Насущной необходимостью в изучении Леонтьева является углубленное исследование его терминологии, часто нуждающейся в исторических экскурсах, в специальных пояснениях. Для этого нужно знать весь корпус его текстов, включая эпистолярий. Ведь часто специфические леонтьевские термины (как, например, «трансцендентный эгоизм ${ }^{3}$ ) и бытовали только в письмах. Внимательного рассмотрения в контексте требует и термин «послушание».

Имя Леонтьева ассоциируется с идеями формы и дисциплины. Нужно непременно подчеркнуть: дисциплины свободной. «Эта дисциплина, этот страх не материальной природы; - это несокрушимая идеальная узда веры, любви и почтения» [Леонтьев 7, кн. 1: 140; «Афон-

\footnotetext{
1 Это не означало полного отказа от чтения светской литературы, но было сродни установке «фильтров».

2 Хотя он и проштудировал, например, известный академический учебник митрополита Макария (Булгакова).

3 См. об этом: [Гольдт].
} 
ские письма» $1872^{1}$ ]. Ср. в статье «Наше болгаробесие» (1879): «Я стал бояться, что мы не сумеем вовремя заменить давление Мусульманства другой, более высокой дисциплиной, - дисциплиной духа, заменить тяжесть жесткого ига суровым внутренним идеалом; унизительный и невольный страх агарянский свободным страхом Божиим...» [Леонтьев 7, кн. 1: 546]. Леонтьев исповедует не слепое подчинение «железному» закону государства (механическое), а осмысленное подчинение Церкви и старцу (органическое). И только «за послушание» Церкви совершается послушание и властям, «от Бога поставленным» [Леонтьев 7, кн. 1: 547].

Само слово «послушание» Леонтьев употребляет не так уж часто, в основном используя его синонимы и близкие понятия (понуждение, отречение, покорность, благоговение, «самоваяние», дисциплина; покаяние; «сердечное общение со старцами» [Леонтьев 8, кн. 1: 439]. Другое дело «послушание» в прикладном понимании («круг обязанностей»): монастырское послушание. Эти случаи встречаются чаще.

За идеей послушания стоит мысль о самопонуждении - свободном, совершаемом в любви и ради любви к Богу и ближним. Аскетическое понимание послушания - это распятие «своей воли», добровольное (хоть и бывающее очень тяжелым для человека) подчинение ее воле Божией, принесения ее в жертву (самоотвержение, самоотречение) и - как следствие, не всегда и не всеми достижимое - возрастание в любви; очищение в себе подобия Божия. «В самоотвержении души обретается любовь Божия», - говорится в 43-м слове Аввы Исаака Сирина) [Исаак Сирин: 183]. Всё это исповедуется и Леонтьевым. Аскетизм он понимает как «регулирование наших чувств и действий во Имя Господне» [Леонтьев 8, кн. 1: 438]. Ничего нового Леонтьев в понимание христианского подвижничества не вносит (разве что он делает более сильный акцент на необходимости самопонуждения), но в секуляризованную эпоху подобная проповедь уже звучит новизной. Тут можно вспомнить приведенные Леонтьевым в письме к о. И. Фуделю слова Вл. Соловьева из неоконченной им статьи о Леонтьеве: «...ннжно большое бесстрашие, чтобы в наше время говорить о страхе религиозном, а не об одной любви» [Преемство от отцов: 283].

1 Первая редакция этого произведения утрачена, сокращенная вторая («Четыре письма с Афона») опубликована посмертно в 1912 г. 
«Послушание» связано с леонтьевской идеей «трансцендентного эгоизма», сосредоточенности на личном спасении, что восходит еще к ветхозаветному «Внемли себе!» (Втор. 15: 9). Спасение за гробом «покупается» ценою отречения и послушания здесь, на земле. Эта образность сопоставима с известной беседой преп. Серафима Саровского с Н. А. Мотовиловым о стяжании Святого Духа, где используется евангельский образ «купли». Сравним в «Афонских письмах»: «В страхе христианском если и есть эгоизм, т. е. забота о загробном спасении души при разочаровании во всем земном и непрочном, то называть этого рода заботу эгоизмом <...> было бы уже слишком недобросовестной натяжкой! <..> благодаря этому воздушному, туманному, отдаленному и неосязательному эгоизму от скольких движений эгоизма грубого, земного, ежедневного освобождается хороший христианин!» [Леонтьев 7, кн. 1: 140] ${ }^{1}$.

Христианство для Леонтьева - религия «свободных ограничений» [Леонтьев 7, кн. 1: 170], «ограничивающая» нас «мистическая ортодоксия» [Леонтьев 7, кн. 2: 9], несентиментальное [Леонтьев 6, кн. 1: 754] учение «воздержания и понуждения» [Леонтьев 6, кн. 1: 750]. Главный «враг» Леонтьева: идеал "рая на земле», идеал «всеобщего благоденствия», «эвдемонизм» как новая религия (религия прогресса и «всеобщей пользы» и довольства), вера «во всеобщее земное благоденствие, которое отныне должно составлять конечную иель человечества» [Леонтьев 7, кн. 1: 151], «самая холодная, прозаическая и вдобавок самая невероятная, неосновательная из всех религий» [Леонтьев 7, кн. 1: 332; «Византизм и Славянство»]. В 1880-е гг. он будет говорить еще и об «антрополатрии» и «автолатрии» [Леонтьев 8, кн. 1: 308]; «Это поклонение человеческой тичности, этот новый род идолопоклонства...» [Леонтьев 7, кн. 2: 81]). Напомним о его борьбе с «розовым христианством» (оно же - «гуманитарное лже-христианство» [Леонтьев 8, кн. 1: 289]; сентиментальное учение «неверующей любви» [Леонтьев 8, кн. 1: 419].

Будущие обличения «нашим новым христианам» просматриваются уже в «Афонских письмах»:

${ }^{1}$ Не исключено, что в позднейшем развитии этой идеи у Леонтьева присутствует скрытая полемика с О. Контом, противопоставлявшим, как известно, альтруизм христианскому «эгоизму». 
Доброта, прощение, милосердие... Они взяли лишь одну сторону Евангельского учения и зовут ее существенной стороной! - Но аскетизм и суровость они забыли? - Но на гневных и строгих Божественных словах они не останавливались? <...> Нельзя, принимая святость Евангелия и Божественность Христа, отвергать одно место в книге и выбирать по вкусу другое. - Все мягкое, сладкое, приятное, облегчающее жизнь принимать, а все грозное, суровое и мучительное отвергать, как несущественное. $<\ldots>$

Религия всепрощения; - да! - Но вместе с тем и религия самобичевания, покаяния, религия не только неумолимой строгости к себе, но и разумной строгости к другим [Леонтьев 7, кн. 1: 144-145].

В статье «Панславизм на Афоне» (1872, опубл. в 1873) Леонтьев отмечал: «Церковь $<\ldots>$ вполне последовательна, и уроков ее не надо забывать, если мы хотим быть в самом деле православными, а не какими-то воздушными, фантастически летающими и порхающими христианами, принимая французскую утилитарную гуманность и немецкий сентиментализм за истинное Христианство» [Леонтьев 7, кн. 1: 236]. В поздней статье Леонтьев приводит слова афонского старца Иеронима: «Одной мягкостью нравов Христианства заменить нельзя» [Леонтьев 8, кн. 1: 419].

Антитезой эвдемонизма выступает аскетизм, исповедающий: «...ничего на земле; ничего для земли» [Леонтьев 7, кн. 1: 153]. Этого идеала придерживалась Византия, к которой и обращается Леонтьев, делая «византизм» своим знаменем. Византия для него - это прежде всего именно аскетическая культура [Леонтьев 7, кн. 1: 171] ${ }^{1}$. «В нравственном міре $\langle\ldots>$ византийский идеал не имеет того высокого и во многих случаях крайне преувеличенного понятия о земной личности человеческой <..> Византизм (как и вообще Христианство) отвергает всякую надежду на всеобщее благоденствие народов <...> он есть сильнейшая антитеза идее всечеловечества в смысле земного всеравенства, земной всесвободы, земного всесовершенства и вседовольства» [Леонтьев 7, кн. 1:300].

«Православие Византийское $<\ldots .>$, - разъяснял Леонтьев, - имеет в себе $<\ldots>$ две стороны: для государственной общественности и для семейной жизни - оно есть религия дисциплины. - Для внутренней

${ }^{1}$ Ср.: «Церковное же чувство и покорность властям (византийская выправка)...» [Леонтьев 7, кн. 1: 324]. 
жизни нашего сердца - оно есть религия разочарования, религия безнадежности на что бы то ни было земное» [Леонтьев 7, кн. 1: 173]. «Православие или, другими словами, культура Византийской дисциплины и земного аскетизма есть единственный противовес теории всеобщего, мелкого удовольствия...» [Леонтьев 7, кн. 1: 174].

Синонимом православной культуры становится для Леонтьева культура монастырская. «Когда я говорю Православие, я говорю духовенство; когда я говорю духовенство, я подразумеваю монастыри...» [Леонтьев 7, кн. 1: 538]. По его мысли, «вопрос о монашестве есть один самых важных в наше время смут и растерянности...» [Леонтьев 7, кн. 2: 209]. «Время наше, наш сложный, спешный образ жизни в мирском обществе мало благоприятствует сосредоточению мыслей на духовных вопросах, и с этой-то стороны монастыри и полезны, как такие центры, в которых это собирание мыслей воедино и поднятие их до нужной высоты и бесплотности достигается несравненно легче, чем в миру» [Леонтьев 8, кн. 1: 418].

В «Афонских письмах», ориентируясь на известные слова преп. Иоанна Лествичника «Свет мирянам иноки, свет инокам ангелы» ${ }^{1}$, Леонтьев показывает низводящую свет лествииу: подвижники (аскеты) монахи - миряне: «Аскет нужен, как путеводная звезда, как крайнее выражение православного отречения <..> Аскет нужен мирянам и Церкви; монастырь нужен аскету <...>. Монастырь нужен и мирянину, как посредствующее звено между городской роскошью и сырой пещерой пустынника» [Леонтьев 7, кн. 1: 157]. «Монах нейдет на проповедь, правда; - но <..>> несколько недель или месяцев жизни при хорошем благочинном монастыре поучает пучше всякой навязчивой проповеди на миру. <...> Хорошо организованная обитель есть уже своего рода пропаганда не словом, а делом самим. - Монашество есть, положим, крайнее выражение Христианства. - Но сила крайности подразумевает неизбежно, органически, так сказать, и прочность чего-то среднего, однородного с ним; но не крайнего, за сим стоящего в порядке развития» [Леонтьев 7, кн. 1: 163].

Леонтьев наглядно объясняет взаимозависимость и взаимообусловленность двух начал, «мира» и «монастыря»: слабый, не по-христиан-

${ }^{1}$ Ср. в «оптинском» переводе: «Свет монахов суть Ангелы, а свет для всех человеков - монашеское житие; и потому да подвизаются иноки быть благим примером во всем...» [Иоанн Лествичник: 181]. 
ски живущий мир может дать только слабое, «недостойное» собственного звания монашество ${ }^{1}$, крепкое "честное» монашество (особенно в своем венце - великих аскетах) влияет на Церковь, а через нее и на мир, укрепляя их и преображая. «Иначе, какое же бы могло иметь значение монашество, если 6 оно не исходило, как высший плод, из того же христианского общества и если бы, с другой стороны, посредством своих молитв, своего примера и своего руководящего влияния, оно на этот внешний христианский мір не влияло?» [Леонтьев 6, кн. 1: 286-287].

«Состояние монастырей» Леонтьев считал одним «из лучших мерил религиозной жизни в исповеданиях, где $<\ldots>$ есть учреждение монашества» [Леонтьев 7, кн. 1: 483]. Он верил, что монашество могут возродить образованные молодые дворяне. Радостные надежды испытывал он в 1890 г., когда писал, по благословению старца, статью «Добрые вести» (парафраз слова «Евангелие», Благая весть). В этой статье не только рассказано о конкретных событиях (монашеских постригах и священнических хиротониях нескольких молодых дворян), сулящих духовное обновление, но затронуты и общие вопросы, в частности о том, что аскетические упражнения и подвижничество доступны и мирянам.

Послушание для Леонтьева - основа, способ существования во всех областях жизни. Прежде всего, в семье. «Строгий, религиозный, нравственный брак есть лишь смягченное монашество; - иночество вдвоем или с детьми-учениками» [Леонтьев 7, кн. 1: 163] 2 .

И опять обнаруживается взаимозависимость: «Для семьи нужна Церковь, для Церкви Православной необходимы примеры крайнего аскетизма; - для аскетизма нужны монастыри...» [Леонтьев 7, кн. 1: 165]. «Без монастырей, без этих скопищ, так сказать, крайнего отречения, пали бы последние основы для поддержки того среднего отречения, которое необходимо для хорошей семьи...» [Леонтьев 7, кн. 1: 166].

${ }^{1}$ Ср. в статье «Панславизм на Афоне»: «...большинство монашества всегда было и не может не быть лишь колеблющимся и нетвердым резервом высшего подвижничества. Без нерешительной толпы невозможны герои аскетизма...» [Леонтьев 7, кн. 1: 231].

2 Ср.: «Монах, в сущности, все тот же православный христианин, как и не монах, только поставленный в особые благоприятные для строгой жизни условия; и мирянин верующий, в сущности, все тот же аскет, только с большею свободой» [Леонтьев 6, кн. 1: 286]. 
В статье «Добрые вести» Леонтьев писал: «Монашество <...> есть высший идеал Христианства. Если есть довольно много умов и сердец, ищущих идеала высшего, то непременно будет в обществе еще несравненно больше таких характеров, которые удовлетворятся средним идеалом - идеалом Христианства семейного и в этой средней сфере будут достигать своего рода наивысшего совершенства и достоинства. Охлаждение к идеалу высшему, отвращение к его крайностям влечет за собою очень скоро глубокий упадок и того среднего состояния, которое сначала большинству казалось достаточным» [Леонтьев 8, кн. 1: 437-438].

«Идеал высшего отречения, раз усвоенный и разумом, и сердцем, непременно отразится <...> на личных житейских вкусах, на государственных вкусах, на семейных правилах. Монашество уже тем полезно для мирян, желающих утвердиться в Христианстве, что оно учит прежде всего себе внимать, о своем загробном спасении заботиться, а "все остальное приложится”. И как бы мы дурны ни были <...> мы при подобном к себе внимании, при боязни согрешить, при памяти о Страшном Суде Христовом, станем все-таки и по отношению к другим людям хоть сколько-нибудь справедливее и добрее» [Леонтьев 8, кн. 1: 417].

Аскетическая проповедь звучит даже в рассуждении Леонтьева о закрытых женских учебных заведениях: «Не этика для этики, не гордый долг для долга, столь часто сомнительный в основах своих <...> но смиренная заповедь “страха Божия” должны быть положены в основы женского воспитания; - если мы хотим утвердить семью будущего на прочных основаниях. <...> Личный идеал обманывает, идеал обще-церковный обмануть не может, ибо он вовсе не радостный, а суровый» [Леонтьев 6, кн. 2: 50-51]; «...mо ли время теперь, чтобы бояться крайностей - мистического, религиозного аскетизма! <..> Всякий знает, что надо жарче топить печь, когда на дворе мороз...» [Леонтьев 6, кн. 2: 52-53].

Нанизывая эти «четки» цитат из текстов Леонтьева разного времени, нельзя не вспомнить и первую его передовую статью в газете «Варшавский дневник» (от 9 января 1880 г.): «Хотя вечного на земле нет ничего, но существуют явления, сравнительно очень прочные. Прочно же у тюдей именно то, что по существу своему противоречит демократической свободе и тому индивидуализму, который она обусловливает. Смесь страха и любви - вот чем должны жить человеческие 
общества, если они жить хотят... Смесь любви и страха в сердцах...; священный ужас перед известными идеальными пределами; любящий страх перед некоторыми тииами; чувство искреннее, а не притворное только для политики; благоговение при виде даже одном иных вещественных предметов, при виде иконы, храма, утвари церковной... Вот что созидает нации, вот что их единит, ведет к победам, славе и могуществу, вот что задерживает их падение надолго даже и тогда, когда падение это вследствие развития демократического индивидуализма становится неотвратимьм в более и менее далеком будущем...» [Леонтьев 7, кн. 2: 10-11].

Идея послушания была осуществлена Леонтьевым в его собственной жизни. В сорокалетнем возрасте он сломил себя, именно «принял послушание» после обета, данного у иконы Божией Матери в час смертельной болезни. Это не было внезапным решением. Известно, что еще за год-два до «обращения» Леонтьев подумывал о монашестве. С 1871 г. (с отъезда на Афон, где он обрел «...великую святыню личного, сердечного Православия» [Леонтьев 7, кн. 1: 205]) Константин Николаевич не оставался без старца. «...старцы Руссика выучили меня послушанию, посту и молитве <...> раскрыли мне истинный дух Церкви...» [Леонтьев 6, кн. 1: 232; «Моя исповедь», 1878].

Леонтьев - это единственный в русской культуре пример писателя, живущего в послушании старцам. Е. Л. Шифферс (1934-1997) удачно назвал его: «Пушкин, принявший монашество» [Шифферс: 498; «Беседа о храме» $]^{1}$. Стоит обратить внимание на то, что все его духовники или уже прославлены во святых или почитаются как великие подвижники Православной Церкви: Иероним (Соломенцев), Макарий (Сушкин), преподобные Амвросий Оптинский, Анатолий Оптинский, Варнава Гефсиманский. Канонизирован и архимандрит Пимен (Мясников), настоятель Николо-Угрешского монастыря, из послушников которого Леонтьев «сбежал» в 1875 г. Настоящим подвижником был и духовный друг Леонтьева, оптинский иеромонах Климент (Зедергольм), в память

${ }^{1}$ Ср. в другой работе того же мыслителя («Аргушти: О поведении царей»): «Розанов сравнивал Леонтьева с Достоевским и Толстым, - вернее увидеть в нем силу Пушкина. - Вот как бы Пушкин встретился со старцем Серафимом и, радостно обретя красоту своего Пимена во плоти, склонился перед ним, - это Леонтьев перед старцем Амвросием. Да: Пушкин, ставший монахом, - таково измерение Константина Николаевича Леонтьева, настоящего русского» [Шифферс: 140] 
о котором и Константину Николаевичу при постриге 18 августа 1891 г. было дано имя Климент.

Леонтьев знал, что говорил, когда заметил в не изданном при жизни послесловии к запискам своей матери: «...молитва и вольная покорность духовным руководителям совершают в нас великие и неожиданные для нас самих внутренние чудеса» [Леонтьев 6, кн. 2: 51]. И это было испытано и получено именно в монастыре, а не «около церковных стен». «Монастырям нашим я столько обязан, я в них нашел столько хорошего, столько настоящего христианского понимания, столько русского чувства, столько поэзии...» [Леонтьев 8, кн. 1: 23]. Заслуженным было замеченное друзьями счастье, испытанное Леонтьевым в последние месяцы жизни - после принятия монашества.

Что же извлекается для сегодняшнего дня из той части леонтьевской «аскетической философии», которая посвящена вопросу о послушании? Прежде всего, это приоритет внимания к спасению собственной души, именно к внутренней жизни человека, четкость критериев, «дисциплина духа», принцип добровольности и свободы.

Аскетические принципы дисциплины и «трезвения» Леонтьев старался вносить и в собственное художественное творчество, причем не только в содержание, но и в «исполнение», применяя на практике те правила, которые сформулировал позднее в своей знаменитой статье «Анализ, стиль и веяние». Стоит вспомнить здесь его рецепт «умственных фильтров», через которые он советовал «процедить» творения Л. Толстого: «1) Упростить <..> язык <...> сделать его больше похожим на язык пушкинской прозы <..>. 2) Уничтожить вообще излишние подглядывания в душу действующих лиц. 3) Выбросить <...> все те выражения, обороты речи и эпитеты, которые слишком в духе послепушкинской школы...» [Леонтьев 9: 363].

Некую проекцию в возможное будущее представляет собой фрагмент из письма к Леонтьеву о. Иосифа Фуделя от 20 февраля 1891 г.: «Когда все образованные люди станут ездить в Оптину, когда духовенство получит руководящую роль, когда общество не будет смотреть на Церковь издали, а будет жить в ней, тогда на этой почве получатся новые культурные всходы, точно также, как в Средние века католичество было основой культурного своеобразия Зап<адной> Европы. Тогда и быт наш изменится, и науки получат новый толчок в известную сторону (Вами проповедуемый пессимизм в науке), и искусство будет иметь 
почву (религиозный характер музыки, развитие церк<овных> песнопений, новые виды Богослужений, новые темы для живописи, новые темы для романов, трагедий и т. д.). Строй жизни тогда может принять оригинальный характер (монашество - как новое сословие, проповедуемое Церковью послушание и смирение, как основы сословной организации, ею же проповедуемая любовь, как основа отношений между сословиями и т. д.). Благоденствия, желаемого В. Соловьевым, не будеm, но оригинальный, своеобразный строй жизни, желаемый Вами, будет» [Преемство от отцов: 292-293].

\section{Список литературы Источники}

Леонтьев К. Н. Полн. собр. соч. и писем: в 12 т. [19 кн.] / подгот. текста и коммент. В. А. Котельникова и О. Л. Фетисенко. СПб.: Владимир Даль, 2000-2021.

[Маковицкий Д. Н.] У Толстого, 1904-1910. «Яснополянские записки» Д. Н. Маковицкого. Кн. 1: 1904-1905 // Литературное наследство. Т. 90: в 4 кн. М.: Наука, 1979. Кн. 1.

«Преемство от отцов»: Константин Леонтьев и Иосиф Фудель: Переписка. Статьи. Воспоминания / сост., вступ. ст., подгот. текста и коммент. О. Л. Фетисенко. СПб.: Владимир Даль, 2012. 751 с.

Преподобного отца нашего Иоанна, игумена Синайской Горы, Лествица, в русском переводе. 7-е изд. Козельской Введенской Оптиной пустыни. Сергиев Посад, 1908. $274 \mathrm{c}$.

Творения Аввы Исаака Сирина. Сергиев Посад, 1911. 435 с.

Шифферс Е. Религиозно-философские произведения. Памятник. Лама: О наречении патриарха. Работы разных лет / сост. и общ. ред. В. Р. Рокитянского; вступ. ст. О. И. Генисаретского. М.: Русский ин-т, 2005. 608 с.

Berdiaeff $N$. Introduction a l'édition française // Berdiaeff N. Constantin Leontieff. Un penseur religieux russe du dix-neuvième siècle / trad. d'H. Izwolski. Paris, 1937. P. 7-10.

\section{Исследования}

Авдеева Л. Р. К. Н. Леонтьев. Пророк или «одинокий мыслитель»? М.: Российское гуманитарное общество, 2012. 158 с.

Гольдт P. Аскетизм как трансцендентальная форма заботы о себе у К. Н. Леонтьева // Изобилие и аскеза в русской литературе: Столкновения, переходы, совпадения: сб. статей / под ред. Й. Херльта и К. Цендера. М.: НЛО, 2020. С. 122-145.

Журавлева А. В. Особенности эсхатологической этики К. Н. Леонтьева URL: https://www.gramota.net/articles/issn_1997-292X_2017_11_13.pdf (дата обращения: 13.02.2021).

Журавлева А. В. «Эстетический аморализм» К. Н. Леонтьева: pro et contra // Известия Тульского гос. университета. Гуманитарные науки. 2017. № 3. С. 133-140. 
Коковкина А. А. Об «эстетическом аморализме» Константина Леонтьева // Духовная деятельность и ее формы: сб. науч. ст. Хабаровск, 1999. С. 14-18.

Котельников В. А. Православные подвижники и русская литература. На пути к Оптиной. М.: Прогресс-Плеяда, 2002. 384 с.

Носов С. Н. Антирационализм в русской литературе второй половины XIX нач. XX (Ап. Григорьев, Конст. Леонтьев, Вл. Соловьев, В. Розанов): автореф. дис. ... д-ра филол. наук. СПб., 1998. 43 с.

Океанский В. П. Христианское осмысление сущности государства в традиции русского православного органицизма: Хомяков - Леонтьев - Солоневич // Традиции в контексте русской культуры. Череповец: Череповецкий гос. пед. ин-т, 1995. С. 135-139.

Репников А. В. «Эстетический аморализм» в произведениях К. Н. Леонтьева. М.: [б. и.], 1999. 39 с.

Фетисенко О. Л. «Гептастилисты»: Константин Леонтьев, его собеседники и ученики. СПб.: Изд-во «Пушкинский Дом», 2012. 784 с.

Фетисенко О. Л. Материнское русло «реки времен» Константина Леонтьева // Константин Леонтьев: Семейный архив: Документальные повести, воспоминания и дневниковые записи Ф. П. Леонтьевой. Письма. СПб.: Изд-во «Пушкинский Дом», 2020. С. 5-36.

\section{References}

Avdeeva, L. R. K. N. Leont'ev. Prorok ili "odinokii myslitel"? [K. N. Leontiev. Prophet or "Lonely Thinker"?] Moscow, Rossiiskoe gumanitarnoe obshchestvo Publ., 2012. 158 p. (In Russ.)

Gol'dt, R. "Asketizm kak transtsendental'naia forma zaboty o sebe u K. N. Leont'eva” [“Asceticism as a Transcendental Form of Self-care in K. N. Leontiev's Works"]. Herlt, J, and K. Zehnder, editors. Izobilie i askeza v russkoi literature: Stolknoveniia, perekhody, sovpadeniia: sb. statei [Abundance and Asceticism in Russian Literature: Collisions, Transitions, Coincidences: Collection of Articles]. Moscow, NLO Publ., 2020, pp. 122-145. (In Russ.)

Zhuravleva, A. V. Osobennosti eskhatologicheskoi etiki K. N. Leont'eva [Peculiarities of K. N. Leontiev's Eschatological Ethics]. Available at: https://www.gramota.net/articles/ issn_1997-292X_2017_11_13.pdf (Accessed 13 February 2021). (In Russ.)

Zhuravleva, A. V. “'Esteticheskii amoralizm' K. N. Leont'eva: pro et contra” [“'Aesthetic Immoralism' by K. N. Leontiev: Pro et Contra”]. Izvestiia Tul'skogo gosudarstvennogo universiteta. Gumanitarnye nauki, no. 3, 2017, pp. 133-140. (In Russ.)

Kokovkina, A. A. "Ob 'esteticheskom amoralizme' Konstantina Leont'eva” ["On the 'Aesthetic Immoralism' of Konstantin Leontiev"]. Dukhovnaia deiatel'nost' $i$ ee formy [Spiritual Activity and Its Forms]. Khabarovsk, 1999, pp. 14-18. (In Russ.)

Kotel'nikov, V. A. Pravoslavnye podvizhniki i russkaia literatura. Na puti $k$ Optinoi [Orthodox Ascetics and Russian Literature. On the Way to Optina Monastery]. Moscow, Progress-Pleiada Publ., 2002. 384 p. (In Russ.) 
Nosov, S. N. Antiratsionalizm v russkoi literature vtoroi poloviny XIX - nach. XX (Ap. Grigor'ev, Konst. Leont'ev, Vl. Solov'ev, V. Rozanov): avtoref. diss. ... dokt. filol. nauk [Anti-rationalism in Russian Literature of the Second Half of the $19^{\text {th }}-$ Early $20^{\text {th }}$ Centuries (Ap. Grigoriev, Konst. Leontiev, Vl. Soloviev, V. Rozanov): DSc thesis]. St. Petersburg, 1998. 43 p. (In Russ.)

Okeanskii, V. P. "Khristianskoe osmyslenie sushchnosti gosudarstva v traditsii russkogo pravoslavnogo organitsizma: Khomiakov - Leont'ev - Solonevich” ["Christian Comprehension of the State Essence in the Tradition of Russian Orthodox Organicism: Khomyakov - Leontiev - Solonevich"]. Traditsii v kontekste russkoi kul'tury [Traditions in the Context of Russian Culture]. Cherepovets, Cherepovetskii gosudarstvennyi pedagogicheskii institut Publ., 1995, pp. 135-139. (In Russ.)

Repnikov, A. V. "Esteticheskii amoralizm” v proizvedeniiakh K. N. Leont'eva ["Aesthetic Immoralism” in K. N. Leontiev's Works]. Moscow, 1999. 39 p. (In Russ.)

Fetisenko, O. L. "Geptastilisty": Konstantin Leont'ev, ego sobesedniki i ucheniki ["Heptastilists": Konstantin Leontiev, His Interlocutors and Students]. St. Petersburg, Pushkinskii Dom Publ., 2012. 784 p. (In Russ.)

Fetisenko, O. L. “Materinskoe ruslo 'reki vremen' Konstantina Leont'eva” ["Maternal Channel of Konstantin Leontyev's 'River of Times.']. Konstantin Leont'ev: Semeinyi arkhiv: Dokumental'nye povesti, vospominaniia i dnevnikovye zapisi F. P. Leont'evoi. Pis'ma [Konstantin Leontiev: Family Archive: Documentary Stories, Memoirs and Diary Entries of F. P. Leontyeva. Letters]. St. Petersburg, Pushkinskii Dom Publ., 2020. pp. 5-36. (In Russ.) 


\title{
О стихотворении М. Н. Муравьева «Живописец» (по материалам ОР РГБ и РО ИРЛИ)
}

\begin{abstract}
Аннотация: Статья посвящена реконструкции творческой истории стихотворения М. Н. Муравьева «Живописец». Первоначально данный текст был опубликован в «Академических известиях» в 1779 г. В отделе рукописей Российской государственной библиотеки (Москва) нами был обнаружен самый ранний автограф этого произведения, который мы датировали 1775 г. Эта редакция сильно отличается от финальной как по объему (она практически в два раза меньше), так и стилистически. В Рукописном отделе Института русской литературы (Санкт-Петербург) мы нашли вторую редакцию «Живописца», согласно нашим доказательствам, написанную в 1778 г. Она находится среди писем Муравьева к Д. И. Хвостову. Столь пристальное внимание поэта к данному стихотворению может быть объяснено тем, что Муравьев высказал в произведении целый ряд важных соображений о природе творчества и о принципах взаимодействия с властью. С нашей точки зрения, «Живописец» - один из ключевых текстов Муравьева, в которых он расписался в верности культурной политике Екатерины II.
\end{abstract}

Ключевье слова: М. Н. Муравьев, Екатерина II, «Живописец», Д. И. Хвостов, творческая история, рукописные редакции, история текста, реконструкция.

Информация об авторе: Александр Дмитриевич Ивинский, кандидат филологических наук, старший научный сотрудник, Институт мировой литературы им. А. М. Горького Российской академии наук, ул. Поварская, д. 25 a, 121069 г. Москва, Россия.

E-mail: ivinskij@gmail.com

Дата поступления статьи в редакцию: 16.02 .2021

Дата одобрения статьи рецензентами: 30.03 .2021

Дата публикации статьи: 28.06.2021

Для циитирования: Ивинский А. Д. О стихотворении М. Н. Муравьева «Живописец» (по материалам ОР РГБ и РО ИРЛИ) // Два века русской классики. 2021. Т. 3, № 2. C. 168-185. https://doi.org/10.22455/2686-7494-2021-3-2-168-185 


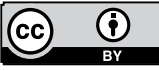

This is an open access article distributed under the Creative Commons Attribution 4.0 International (CC BY 4.0)
Dva veka russkoi klassiki, vol. 3, no. 2, 2021, pp. 168-185. ISSN 2686-7494 Two centuries of the Russian classics, vol. 3, no. 2, 2021, pp. 168-185. ISSN 2686-7494

Research Article

() 2021. Alexander D. Ivinskiy

A. M. Gorky Institute of World Literature of the Russian Academy of Sciences

Moscow, Russia

\title{
On Mikhail Muravyov's Poem The Painter (Based on Materials of Russian State Library and Institute of Russian Literature)
}

\begin{abstract}
The article is devoted to the textual reconstruction of the poem The Painter by M. N. Muravyov. It was published in "Academic News" in 1779. In the Manuscripts Department of the Russian State Library (Moscow), we have found the earliest manuscript of this work, which we date 1775 . This variant differs greatly from the final one - both in terms of volume and style. In the Manuscript Department of the Institute of Russian Literature (St. Petersburg), we found the second version of The Painter, written, as we claim, in 1778. It was stored with Muravyov's letters to Dmitry Khvostov. Such close attention of the author to this poem could be explained by the fact that he expressed in it some crucial ideas about the nature of creativity and about the principles of interaction with the authorities. From our point of view, The Painter is one of Muravyov's key texts, in which he acclaimed his loyalty to the cultural policy of Catherine II.

Keywords: Mikhail Muravyov, Catherine the Great, The Painter, Dmitry Khvostov, creative history, handwritten editions, text history, reconstruction.

Information about the author: Aleksandr $\mathrm{D}$. Ivinskiy, $\mathrm{PhD}$ in Philology, Senior Researcher, A. M. Gorky Institute of World Literature of the Russian Academy of Sciences, Povarskaya 25 a, 121069 Moscow, Russia.

E-mail: ivinskij@gmail.com

Received: February 16, 2021

Approved after reviewing: March 30, 2021

Published: June 28, 2021

For citation: Ivinskiy, A. D. “On Mikhail Muravyov's Poem The Painter (Based on Materials of Russian State Library and Institute of Russian Literature)." Dva veka russkoi klassiki, vol. 3, no. 2, 2021, pp. 168-185. (In Russ.) https://doi.org/10.22455/2686-7494-2021-3-2-168-185
\end{abstract}


М. Н. Муравьев опубликовал только шесть небольших поэтических книг, все они были напечатаны в течение двух лет - с 1773 по 1775 гг. [Муравьев 1773; Муравьев 1774a; Муравьев 1774b; Муравьев 1774c; Муравьев 1775]'‥ Как отметила Л. И. Кулакова, «последний прижизненный сборник стихотворений Муравьева вышел из печати, когда автору было 18 лет» [Муравьев 1967: 319]. При этом в рукописях остались десятки текстов, которые постепенно вводятся в научный оборот [Алехина 1990; Росси 1997; Лазарчук, Левин 1999; Росси 2013; Лазарчук 2006; Ивинский 2018; Ивинский 2019; Ивинский 2021]. Можно было бы предположить, что Муравьев просто не хотел тратить время на подготовку своих изданий и печатался в журналах, однако и это не так: как указал В. Н. Топоров, с 1777 по 1797 гг. поэт опубликовал всего 25 произведений, и только пять из них после 1779 г. [Топоров 2003: 73]. Таким образом, именно 1770-е гг. оказываются временем наиболее активного участия Муравьева в литературной жизни. Тем важнее обратиться к изучению именно тех текстов, которые поэт напечатал и которые приближают нас к пониманию его литературной позиции.

В данной статье предпринят опыт реконструкции истории текста стихотворения Муравьева «Живописец» (1778). Это произведение во многом уникально; как указал В. Н. Топоров, лишь «однажды стихотворный текст у Муравьева специфицируется как сказка - «Живописец. Сказка» (1778)» [Топоров 2003: 88]. Рукописи поэта рассеяны по архивам Москвы и Санкт-Петербурга, не стали исключением и редакции данного произведения ${ }^{2}$. Но прежде чем перейти к их характеристике, приведем уже известный текст (далее $-<1>$ ):

1 О них подробнее см.: [Топоров 2003: 11-73].

2 Л. Росси указала, что в РНБ хранятся «отдельные стихотворения, уже опубликованные и снова переписанные», в частности, и «Живописец» [Росси 2013: 201]. 


$$
\begin{gathered}
<1> \\
\text { Живописец } \\
\text { Сказка } \\
1778 .
\end{gathered}
$$

Питомец Рюбенсов, гласит повествованье, Такой, в котором сам учитель открывал Всечасно новое, таившесь дарованье:

Во граде, коего запомнил я названье,

Свое жилище основал

И кистию своей пленял и сам пленялся,

В художестве своем прекрасном упражнялся.

Одною он чертой красавиц оживлял.

Здесь мать свирепую любовей изъявлял,

Вкруг резвятся любови.

Там бога Фракии грядуща представлял Лиются токи крови.

Цари любуются зреть кисть в его руках, Дивятся мудрецы, и знатоки толкуют, Завистники в углу и шепча критикуют, Богач на Гектора взираючи в очках

Едва жалеет о мешках.

Нет девушки, собой хотя немножко страстной (Не ставлю этот пол я подле богача;

Но все ль бы я сказал довод сей умолча?), Нет девушки на этом несогласной, Чтоб кистью мастера подоле быть прекрасной. В таком-то счастье дни катилися его.

Владычества того владетель, Наполнен чувствий сам, художеств благодетель И может быть таков, как первый Медицис, По гласу коего науки родились; Не мнил унизиться влеченью повинуясь Предупрежденныя души своей к нему, И кисти нежныя твореньями любуясь Творца их пригласил к общенью своему, В свои чертоги ввел: дал место в приближенных, 
Где тысящи уходищ потаенных

Служили, кажется, всем прихотям его;

Уединения не руша самого.

Сначала мнил свою он душу омраченну.

Ее к самой себе возврату ожидал.

Оставив часто речь в средине пресеченну,

Уединялся, кисть без пользы утруждал;

Но дар упрямился, когда он принуждал.

Покинула его сия волшебна сила,

Котора на платно все чувства преносила.

Исчез художник в нем: остался человек,

Всех прелестей лишен; тем боле в униженье,

Что дарованья он терпел изнеможенье.

И се уж разум гас, и цвет лица поблек,

И медленно его ко гробу влек

Недвижимости сон и чувствие упадка.

В своих рисунках взор питает каждый день,

И с ним задумчивость. Там почерк, свет иль тень

Становится виной воспоминанья сладка.

Однажды вшед к нему во храмину сей Князь

Пред собственной его картиною сретает,

Не зряща, сладостной тоской обременясь,

Вкушающа слезу, что вдоль ланиты тает:

Завидующего руки своей чертам.

Когда же, разлиясь, отрады упоенье

Прешло в успокоенье

И душу забавлять оставило мечтам,

Он царя ${ }^{1}$ зрит: его колена он объемлет

И ежели твой слух несчастных стону внемлет,

Неблагодарного ты жалобы прости,

Над коим погубил ты столько даров счастья,

Не могши ничего чрез них произвести,

Как только бедного лишить его пристрастья.

Оно вся жизнь моя.

1 В журнальной версии именно так: «Он царя зрит»; Л. И. Кулакова, видимо, случайно изменила «царя» на «князя» [Муравьев 1967: 175]. 
Ты дал мне злато, честь, пожаловал досугом, Из низкой хижины извел и назвал другом.

Но в хижине писал сию картину я.

Воззри, какая разность!

Сокровища пришли и дар меня убег!

Послуша тя чресчур я роскошей и нег

И к сердцу допустил отмщающую праздность.

$\mathrm{Ax}$ ! я за то плачу!

Другим веселья, честь и общества угодны:

Мне труд, и легка кисть, и зрелища природны.

Зачем я жребия другого захочу?

Коль смею, государь, твою воспомнить нежность;

Возьми сокровища сей блеск, сию мятежность,

Возьми прочь роскоши, от коих признаюсь,

С жаленьем расстаюсь.

Отдай мне бедность ты, отдай мою прилежность.

Все пышности сии, не буди прогневлен, Сравняются ль чертой с малейшею корыстью, Я кои похищал из недр природы кистью? И их вкусил ли я? был только удивлен.

Ах! есть ли кто-нибудь, кто б не был ослеплен?

Скончался разговор обоих умиленьем, Простерты руки их друг друга обняли,

И слезы их текли.

И не поставил царь сих чувствий преступленьем.

Повествование сказует нам потом,

Что в хижине нашел художник дарованье,

Что часто царь к нему украдывался в дом

И живописец ввек не сожалел о том,

Что дара своего исполнил он призванье

[Муравьев 1779: 373-378] ${ }^{1}$.

Попробуем рассмотреть творческую историю данного текста, ориентируясь на доступные нам рукописные редакции.

1 Л. И. Кулакова напечатала «Живописца» именно по этому изданию [Муравьев 1968: 173-175]. 
Не учтенный до сих пор автограф «Живописца» (далее $-<2>$ ) находится в «Записной книге» Муравьева ${ }^{1}$. Это ранняя редакция произведения, о чем свидетельствует, во-первых, тот факт, что Муравьев, набрасывая этот текст, не определился еще с его жанром: здесь он обозначен как басня. $<2>$ не датирован, однако мы можем высказать гипотезу о времени его написания: этот текст - часть «журнала» «Услаждение скуки», который помечен 1775 г. $^{2}$ В целом выглядит логичным, что поэт, в 1773 г. издавший книгу басен, вновь вернулся к этой форме и продолжил работать в привычной манере. Если это так, то можно предположить, что изменение жанрового подзаголовка должно было стать маркером изменения культурного контекста и литературного окружения. Благодаря переписке Муравьева мы знаем, что новая жизнь для поэта началась в 1776 г. - после переезда в столицу, поступления на военную службу и знакомства с ведущими поэтами эпохи, в первую очередь, с М. М. Херасковым, В. И. Майковым, В. П. Петровым и др. С их помощью, Муравьев, возможно, обогатил свое представление и о литературной сказке, которая, как хорошо известно, была исключительно распространенной формой во второй половине XVIII в.

Во-вторых, еще одним свидетельством в пользу раннего происхождения <2> служит ее объем. Так, «басня» обрывалась на 55 строке стихотворения, в окончательной же версии их 96. Напрашивается вывод о том, что это первая или, по крайней мере, одна из первых редакций «Живописца».

B-третьих, обратим внимание на характер правки от $<2>$ к $<1>$ : Мyравьев последовательно модернизировал язык своего произведения, избавляясь от устаревших или просто неудачных конструкций. Все варианты мы выделили в представленном ниже тексте курсивом, сейчас же остановимся на одном примере.

Вот вариант из $<2>$ :

\footnotetext{
${ }^{1}$ Муравьев М. Н. Записная книга - стихотворения, поэмы, драматические произведения, заметки о литературе 1771-1803 // ОР РГБ. Ф. 178. № 11161.1. Л. 51. Об этом источнике подробнее см.: [Алехина 1991]; некоторые тексты из этого источника были опубликованы нами: \{Ивинский 2018; Ивинский 2019; Ивинский 2021].

2 «Записная книга» - сложно устроенная рукопись: Муравьев часто возвращался к ранним стихотворениям, правил их, дополнял, на полях записывал новые сочинения. Однако в данном случае никаких правок не было.
} 
Оставя никогда он речь непресеченну

Уединялся, кисть без пользы утруждал

Но дух сей прежних черт, сих черт уж не рождал

Покинула его сия волшебна сила,

Котора на платно все чувства преносила.

А вот итоговая редакция $<1>$ :

Оставив часто речь в средине пресеченну,

Уединялся, кисть без пользы утруждал:

Но дар упрямился, когда он принуждал.

Покинула его сия волшебна сила,

Котора на платно все чувства преносила.

Мы видим, что Муравьев значительно отредактировал этот кусок текста: так, например, в первой строке он в целом перестроил фразу и убрал двойное отрицание «никогда... не». В третьей строке Муравьев избавился от действительно кажущегося излишним повтора «дух сей прежних черт, сих черт...».

Таким образом, эти соображения позволяют нам высказать осторожное предположение, что редакция «Живописца» в «Записной книге» была первой и могла быть написана в 1775 г. (мы выделили курсивом отличия $<2>$ от $<1>$ ).

Басня Живописец

Питомец Рюбенсов, гласит повествованье, Такой, в котором сам учитель открывал

Великой мастер сам с восторгом дарованье,

Во граде, коего запомнил я названье,

Свое жилище основал

И кистию своей пленял и сам пленялся,

В художестве своем прелестном упражнялся.

Одною он чертой красавиц оживлял.

Здесь душ ияарииу изъявлял,

Вкруг резвятся любови. 
Там Марса представлял, Лиются токи крови.

Князья любуются зреть кисть в его руках, Богач на Гектора взираючи в очках Не мыслит о мешках;

Нет девушки, собой хотя немножко страстной (Не ставлю этот пол я подле богача, Но я б не всё сказал, довод сей умолча:

Не сыщешь девушки, на этом несогласной, Чтоб кистью мастера подоле быть прекрасной. В таком-то счастье дни катилися его.

\section{Того}

Княжения владетель

Наполнен чувствий сам, художеств благодетель И, может быть, таков, как первый Медицис, По гласу коего науки родились, Не мнил унизиться, влеченью повинуясь Предупрежденныя души своей к нему И кисти нежныя твореньями любуясь Творца их приобщил

Чертоги разделил: дал место в приближенных,

Где тысящи уходищ потаенных Служили, кажется, всем прихотям его, Уединения не руша самаго.

Сначала мнил свою он душу омраченну. И возвращения ея он долго ждал Оставя никогда он речь непресеченну Уединялся, кисть без пользы утруждал Но дух сей прежних черт, сих черт уж не рождал Покинула его сия волшебна сила, Котора на платно все чувства преносила. Исчез художник в нем: остался человек, Всех прелестей лишен; тем боле в униженье, Что дарованья он терпел изнеможенье. Стал гаснуть луч ума и ивет тица поблек И медленно его ко гробу влек 
Недвижимости сон и чувствие упадка

Своим рисунком взор питает каждый день,

И с ним задумчивость. Там почерк, свет иль тень

Становится виной воспоминанья сладка.

Однажды вшед к нему во храмину сей князь

Пред собственной его картиною сретает,

Не зряща, сладостной тоской обременясь,

Вкушающа слезу, что вдоль ланиты тает

Завидующаго руки своей чертам ${ }^{1}$.

Еще одну редакцию «Живописца» находим в фонде Д. И. Хвостова в РО ИРЛИ (далее - <3>). Нам представляется, что она могла быть написана позже $<2>$, вероятнее всего, в 1778 г. Несмотря на то что в ней отсутствуют название и жанровый подзаголовок, объем рукописи практически совпадает с финальным вариантом: 101 строка вместо 96. Возможно, редактируя <3>, Муравьев и создал окончательную версию. Показательно, что последние 9 строк стихотворения были набросаны уже после переписывания текста набело для отправки Хвостову: они написаны другими чернилами и менее четким почерком, что явно указывает на спешку автора, которого, возможно, в последний момент посетило вдохновение.

Рукопись без даты, находится она среди бумаг Хвостова, расположена рядом с недатированным же письмом Муравьева, содержание которого, однако, позволяет понять, когда оно писалось, ср.: «Мне давно хотелось исполнить мое обещание прислать вам четвертую часть трудов нашего собрания; наконец я его исполняю. Если мне позволено говорить за то, что тут помещено моего, то я прошу вашего внимания только для IV и VI пьесы»². Очевидно, речь идет об «Опыте трудов Вольного российского собрания при Императорском Московском университете», в четвёртой части которых в 1778 г. Муравьев напечатал «Жалобы музам», «Эпистолу к Н. Р. Р.**», «Рощу», «Горациеву девятую оду книги первой к Талиарху», «Его же первую на десять оду книги первой к Левконое» и «Письмо Горациево к Виннию Азелле». Таким образом, у нас есть косвенное свидетельство в пользу того, что <3> могла быть написана также в 1778 г. или по крайней мере непринципиально раньше.

${ }^{1}$ Муравьев М. Н. Записная книга. Л. 51

2 Хвостов Д. И. Рукописный сборник // РО ИРЛИ. Ф. 322. Ед. хр. 59. Л. 40. 
В любом случае $<3>$ отражает следующий этап работы над произведением: мы видим, что текст $<2>$ подвергся существенной стилистической правке, при этом она явно носила промежуточный характер, так как в финальную версию были также внесены корректировки (мы выделили курсивом отличия $<3>$ от $<1>$ и жирным шрифтом - от $<2>$ ); кроме того, как мы уже указывали выше, <3> был расширен практически вдвое по сравнению с $<2>$.

$$
<3>
$$

Питомец Рюбенсов, гласит повествованье,

В котором каждой день учитель открывал

До сель и от него таившесь дарованье,

Во граде, коего запомнил я названье,

Свое жилище основал

И кистию своей пленял и сам пленялся,

В художестве своем прекрасном упражнялся.

Одною он чертой красавиц оживлял.

Здесь душ царицу изъявлял,

Вкруг резвятся любови.

Там Марса представлял,

Лиются токи крови.

Князья любуются зреть кисть в его руках,

Дивятся щеголи и знатоки толкуют,

Завистники в углу и шепча критикуют,

Богач, на Гектора взираючи в очках,

Не мыслит о мешках.

Нет девушки, собой хотя немножко страстной

(Не ставлю этот пол я подле богача,

Но всё ль бы я сказал, довод сей умолча?),

Девицы нет, на это несогласной,

Чтоб кистью мастера подоле быть прекрасной.

В таком-то счастье дни катилися его.

Того

Княжения владетель,

Наполнен чувствий сам, художеств благодетель

И, может быть, таков, как первый Медицис,

По гласу коего науки родились, 
Не мнил унизиться, влеченью повинуясь Предупрежденныя души своей к нему И кисти нежныя твореньями любуясь, Творца их пригласил к общенью своему. Чертоги разделил: дал место в приближенных, Где тысящи уходищ потаенных Служили, кажется, всем прихотям его, Уединения не руша самого.

С начала мнил свою он душу омраченну. И возвращения ея он долго ждал

Оставив часто речь свою непресеченну, Уединялся, кисть без пользы утруждал; Но ум привычных черт, сих черт уж не рождал Покинула его сия волшебна сила, Котора наплатно все чувства преносила. Исчез художник в нем: остался человек, Всех прелестей лишен; тем боле в униженье, Что дарованья он терпел изнеможенье.

И се уж разум час и цвет лица поблек, И медленно его ко гробу влек

Отчаяния сон и чувствие упадка.

В своих рисунках взор питает каждой день, И с ним задумчивость. Там почерк, свет иль тень Становится виной воспоминанья сладка.

Однажды вшед к нему во храмину сей князь Пред собственной его картиною сретает, Не зряща, сладостной тоской обременясь, Вкушающа слезу, что вдоль ланиты тает Завидующаго руки своей чертам.

Когда же разлиясь отрады упоенье Прешло в успокоенье

И душу забавлять оставило мечтам, Он князя зрит; его колена он объемлет, И ежели твой слух не втуне бедных внемлет, Неблагодарного роптания прости, Над коим погубил ты столько даров щастья, Не могши ничего во мне произвести, 
Как только бедного лишить его пристрастья.

Оно вся жизнь моя.

Ты дал мне злато, честь, пожаловал досугом,

Из низкой хижины извел и назвал другом.

Но в хижине писал сию картину я.

Воззри, какая разность!

Сокровища пришли и дар меня убег!

Послушался чрез чур я роскошей и нег

И к сердцу допустил отмщающую праздность.

$\mathrm{Ax}$ ! я за то плачу!

Другим утехи, лень, сообщества угодны;

Мне труд, и легка кисть, и зрелища природны.

Зачем я жребия другого захочу?

Я смею нарицать твою мне в помочь нежность,

Возьми сокровища, оставя неизбежность;

Возьми прочь роскоши, от коих, признаюсь,

С жаленьем расстаюсь.

Отдай мне бедность ты, отдай мою прилежность.

Все пышности сии, не буди прогневлен,

Сравняются ль чертой с малейшею корыстью, Я кои похищал из недр природы кистью?

И их вкусил ли я? был только удивлен.

Ax! есть ли кто нибудь, кто б не был ослеплен?

Пусти меня. Авось в уединенье,

Я прелести сыщу опять во упражненье.

И нравов простота и долг и нужда жить,

За мною будут бдеть и могут вкус вложить.

Скончался разговор обоих умиленьем,

Смешенны руки их друг друга обняли,

И слезы их текли.

И не поставил царь сих чувствий преступленьем.

Повествование сказует нам потом,

Что в хижине нашел художник дарованье,

Что часто Князь к нему украдывался в дом

И живописец ввек не сожалел о том,

Что дара своего исполнил он призванье ${ }^{1}$.

${ }^{1}$ РО ИРЛИ. Ф. 322. Ед. хр. 59. Л. 38-39 об. 
Теперь остановимся на проблематике данного произведения, которое занимало Муравьева сравнительно долгое время и оказалось одним из немногих опубликованных им текстов.

Л. И. Кулакова высказала гипотезу, согласно которой «Живописец» был знаком отхода Муравьева от одической поэтики и при этом отражал его новую идеологическую позицию: «Не принял Муравьев и официальных требований воспеть “мать отечества" и благоденствие ее подданных. И ранее не любивший оды, он после 1775 года перестает писать их совсем, с возмущением говорит о “подлой лести” В. Рубана, который написал оду очередному фавориту Екатерины II, о том, что Рубан достоин презрения. "Ханыков от омерзения Рубана перешел к омерзению стихотворства”, - замечает он в дневнике. Муравьев не приходит к “омерзению стихотворства”, но через некоторое время он пишет сказку “Живописец” (1778), посвященную мысли о необходимости полной творческой свободы в искусстве. Приближаясь даже к благожелательно настроенным “великим и сильным”, художник теряет дарование» [Муравьев 1967: 25]. Л. И. Кулакова в данном случае явно апеллировала к построениям Г. А. Гуковского и пыталась включить Муравьева в число «фрондеров», бросивших вызов двору и Екатерине II. Дело не только в том, что биография и творчество Муравьева не дают для таких предположений никаких оснований, но и в том, что сам текст произведения, очевидно, им противоречит. Муравьев, прекрасно чувствовавший идеологическую конъюнктуру, создал стихотворение, которое легко вписывалось в контекст культурной политики Екатерины II (напомним в связи с этим, что всего через несколько лет Муравьев напечатает несколько текстов в ее «Собеседнике любителей российского слова», затем станет учителем великих князей Александра и Константина Павловичей и потратит много времени на усвоение и реинтерпретацию исторических и лингвистических трудов императрицы [Ивинский 2016; Ивинский 2021].

Муравьев посвятил «Живописца» взаимоотношениям художника и власти; при этом сама модель меценатства нисколько не ставилась под сомнение, напротив, люди вроде Козимо Медичи называлась «благодетелями», их роль трудно переоценить, ведь «по гласу» их «науки родились». Горацианская ${ }^{1}$ по своей природе проповедь ограниченной

\footnotetext{
${ }^{1}$ Напомним, что Гораций - один из любимейших поэтов Муравьева, которого он много переводил. См. подробнее: [Ивинский 2021].
} 
и спокойной жизни на лоне природы, в «хижине», не должна вводить в заблуждение: разумеется, это не «сатира», как казалось Л. И. Кулаковой, а, напротив, утверждение позиции, толерантной к придворной этике. Художник выполняет важнейшую функцию - сохранения памяти о славе царей, но его место за холстом, а не во властных коридоpax. Концовка этого текста очень продуманна и политически выверена, возможно, поэтому он не сразу пришел к этой формуле, но, найдя ее, решил напечатать весь текст и остался им доволен: живописец «исполнил» свое «призванье», а царь иногда наведывался к нему, чтобы насладиться произведением искусства. Гармония восстановилась: у каждого в сложно устроенном придворном мире своя роль, и не нужно даже пытаться выходить за пределы своего социального амплуа:
Повествование сказует нам потом,
Что в хижине нашел художник дарованье,
Что часто царь к нему украдывался в дом
И живописец ввек не сожалел о том,
Что дара своего исполнил он призванье.

Итак, «Живописец» - одно из ключевых произведений Муравьева 1770-х гг., в котором он высказал целый ряд важных для него идей и расписался в верности придворной политике Екатерины II. Благодаря материалам ОР РГБ и РО ИРЛИ мы попытались реконструировать, хотя бы в первом приближении, ход работы поэта над этим текстом: приступил он к нему, скорее всего, в 1775 г., вторую редакцию написал в 1778 г., а в 1779 г. напечатал итоговый вариант в «Академических известиях». 


\section{Список литературы \\ Источники}

Муравьев М. Н. Басни. Книга 1. СПб.: [Тип. Сухопут. кадет. корпуса], 1773. 33 с. Муравьев М. Н. Военная песнь. СПб.: [Тип. Акад. наук], 1774. 26 с.

Муравьев М. Н. Ода ее императорскому величеству государыне Екатерине II, императрице всероссийской, на замирение России с Портою Оттоманскою. СПб.: [б.и.], 1774.10 с.

Муравьев М. Н. Оды Лейб-гвардии Измайловскаго полку сержанта. Михайла Муравьева. СПб.: Тип. Акад. наук, 1775. 30 с.

Муравьев М. Н. Переводные стихотворения». СПб.: Императ. акад. наук, 1773. $32 \mathrm{c}$.

Муравьев М. Н. Петрония Арбитра Гражданская брань: Поема / С латинскаго языка перевел лейб-гвардии Измайловскаго полку каптенармус, Михайло Муравьев. [СПб.] : [Тип. Акад. наук], [1774]. 15 с.

Муравьев М. Н. Живописец. Сказка // Академические известия. СПб., 1779. Ч. 4. C. 373-378.

Муравьев М. Н. Стихотворения. Л.: Сов. писатель, 1967. 389 с.

\section{Исследования}

Алехина Л. И. Архивные материалы М. Н. Муравьева в фондах Отдела рукописей // Записки Отдела рукописей Государственной библиотеки СССР им. В. И. Ленина. М. Книжная палата, 1990. Вып. 49. С. 4-87.

Ивинский А. Д. Екатерина II, М. Н. Муравьев и Карамзин: К вопросу о контекстах «Истории государства российского» // Литературоведческий журнал. 2016. № 40. С. $146-167$.

Ивинский А. Д. О драматургии М. Н. Муравьева (по материалам ОР РГБ и ОПИ ГИМ) // Известия РАН. Серия литературы и языка. 2018. Т. 77, № 3. С. 62-71.

Ивинский А. Д. М. Н. Муравьев и Буало (По материалам отдела рукописей РГБ) // Известия РАН. Серия литературы и языка. 2019. Т. 78, № 2. С. 33-40.

Ивинский А. Д. М. Н. Муравьев, Екатерина II и Фридрих II: к вопросу о статусе литературного языка // Известия РАН. Серия литературы и языка. 2021. Т. 80, № 2. C. 30-37.

Ивинский А. Д. М. Н. Муравьев и античные поэты: неопубликованные переводы // Studia Litterarum. 2021. Т. 6, № 2. С. 358-385. https://doi.org/10.22455/2500-42472021-6-2-358-385

Лазарчук Р. М., Левин Ю. М. «Гамлетов монолог» в переводе М. Н. Муравьева // XVIII век. 1999. Сб. 21. С. 303-317.

Лазарчук Р. М. Неизвестные тексты М. Н. Муравьева (переводы басен Лафонтена) // XVIII век. 2006. Сб. 24. С. 312-316.

Росси Л. В поисках неизвестного произведения Михаила Муравьева // Рукописи. Редкие издания. Архивы. М.: Изд-во Московского ун-та, 1997. С. 127-143

Росси Л. Стихотворная басня М.Н. Муравьева «Изгнание Аполлона» и ее прозаический источник // Чтения отдела русской литературы XVIII века. М. В. Ломоно- 
сов и словесность его времени. Перевод и подражание в русской литературе XVIII века. М.; СПб.: Альянс-Архео, 2013. С. 198-208.

Топоров В. Н. Из истории русской литературы. Т. 2: Русская литература второй половины XVIII века. М. Н. Муравьев. Введение в творческое наследие. М.: Языки русской культуры, 2003. Кн. 2.

\section{References}

Alekhina, L. I. "Arkhivnye materialy M. N. Murav'eva v fondakh Otdela rukopisei" ["Archival Materials of M. N. Muravyov in the Manuscript Department Collections"]. Zapiski Otdela rukopisei Gosudarstvennoi biblioteki SSSR im. V. I. Lenina [V. I. Lenin USSR State Library Manuscript Department Proceedings], no. 49. Moscow, Knizhnaia palata Publ., 1990, pp. 4-87. (In Russ.)

Ivinskii, A. D. “Ekaterina II, M. N. Murav'ev i Karamzin: K voprosu o kontekstakh 'Istorii gosudarstva rossiiskogo"' ["Catherine II, Muravyov and Karamzin: On the Contexts of 'History of Russian State."']. Literaturovedcheskii zhurnal, no. 40, 2016, pp. 146-167. (In Russ.)

Ivinskii, A. D. "O dramaturgii M. N. Murav'eva (po materialam OR RGB i OPI GIM)” ["On the Dramatic Heritage of M. N. Muravyov (Based on Materials of RSL and OPI GIM)”']. Izvestiia Rossiiskoi akademii nauk. Seriia literatury i iazyka, vol. 77, no. 3, 2018, pp. 62-71. (In Russ.)

Ivinskii, A. D. "M. N. Murav'ev i Bualo (Po materialam otdela rukopisei RGB)" ["Mikhail Muravyov and Boileau (Based on Materials of Russian State Library)"]. Izvestiia Rossiiskoi akademii nauk. Seriia literatury i iazyka, vol. 78, no. 2, 2019, pp. 33-40. (In Russ.)

Ivinskii, A. D. “M. N. Murav'ev, Ekaterina II i Fridrikh II: K Voprosu o Statuse Literaturnogo Iazyka" ["Mikhail Muravyov, Catherine II and Friedrich II: On the Literary Language Status"]. Izvestiia Rossiiskoi akademii nauk. Seriia literatury i iazyka, vol. 80, no. 2, 2021, pp. 30-37. (In Russ.)

Ivinskii, A. D. "M. N. Murav'ev i antichnye pojety: neopublikovannye perevody" [“M. N. Muravyov and Ancient Poets: Unpublished Translations”]. Studia Litterarum, vol. 6, no. 2, 2021, pp. 358-385. https://doi.org/10.22455/2500-4247-2021-6-2-358-385 (In Russ.)

Lazarchuk, R. M., Levin, Iu. M. “'Gamletov monolog' v perevode M. N. Murav'eva” [“'Hamlet's Soliloquy' Translated by Mikhail Muravyov”]. XVIII vek [ $18^{h}$ Century], vol. 21, 1999, pp. 303-317. (In Russ.)

Lazarchuk, R. M. "Neizvestnye teksty M. N. Murav'eva (perevody basen Lafontena)" ["Unknown Texts of Mikhail Muravyov (Translations of La Fontaine’s Fables)"]. XVIII vek [18 ${ }^{\text {th }}$ Century], vol. 24, 2006, pp. 312-316. (In Russ.)

Rossi, L. "V poiskakh neizvestnogo proizvedeniia Mikhaila Murav'eva" ["Searching for an Unknown Work of Mikhail Muravyov"]. Rukopisi. Redkie izdaniia. Arkhivy [Manuscripts. Rare Editions. Archives]. Moscow, 1997, pp. 127-143. (In Russ.)

Rossi, L. “Stikhotvornaia Basnia M. N. Murav'eva 'Izgnanie Apollona' i Ee Prozaicheskii Istochnik" ["The Poetic Fable of M.N. Muravyov 'The Expulsion of Apollo' and Its Prosaic 
Source"]. Chteniia otdela russkoi literatury XVIII veka. M. V. Lomonosov i slovesnost' ego vremeni. Perevod $i$ podrazhanie $v$ russkoi literature XVIII veka [Proceedings of the Department of Russian Literature of the $18^{\text {th }}$ century. $M$. V. Lomonosov and the Literature of His Time. Translation and Imitation in Russian Literature of the $18^{\text {th }}$ century]. Moscow, St. Petersburg, Al'ians-Arkheo Publ., 2013, pp. 198-208. (In Russ.)

Toporov, V. N. Iz istorii russkoi literatury. T. 2. Russkaia literatura vtoroi poloviny XVIII veka. M. N. Murav'ev. Vvedenie v tvorcheskoe nasledie [From the History of Russian Literature. Vol. 2. Russian Literature of the Second Half of the $18^{\text {th }}$ Century. M. N. Muravyov: Introduction to the Heritage], vol. 2. Moscow, Iazyki russkoi kul'tury Publ., 2003. (In Russ.) 


\title{
«Основной бас»: к истории одного музыкального образа в романе Л. Н. Толстого «Анна Каренина»
}

\begin{abstract}
Аннотация: В статье рассмотрена история музыкального термина, превращенного Л. Н. Толстым в романе «Анна Каренина» в художественный образ, участвующий в раскрытии важной для автора и его героя Константина Левина темы устройства земледельческого хозяйства в России. Избрав музыкальный термин для наиболее точного выражения своей мысли, Толстой уподобляет различные темы повествования отдельным голосам в полифоническом произведении, где роль главного голоса отведена «основному басу» - впечатлению, произведенному на Левина хозяйством старого мудрого крестьянина. Вполне закономерное для любившего и изучавшего музыку писателя художественное решение показалось редакторам, готовившим публикации романа «Анна Каренина» в течение всего XX в., настолько необычным, что было принято ими за ошибку копииста или наборщика. Следствием этого стала замена многозначного музыкального термина «основной бас» на словосочетание «основной базис». Обращение к автографам не дает ответа на вопрос, который из двух вариантов верен, так как рукописный фонд романа сохранился не полностью. Единственным формальным источником, позволяющим текстологу восстановить первоначальный вариант, является исправленный Толстым в 1877 г. текст первой публикации романа в журнале «Русский вестник» (1875-1877), по которому в настоящее время «Анна Каренина» печатается в академическом Полном собрании сочинений Л. Н. Толстого в 100 томах.
\end{abstract}

Ключевые слова: Л. Н. Толстой, «Анна Каренина», текстология, художественное творчество, музыкальный термин, история текста, подготовка издания.

Информация об авторе: Марина Анатольевна Можарова, кандидат филологических наук, старший научный сотрудник, Институт мировой литературы им. А. М. Горького Российской академии наук, ул. Поварская, д. 25 a, 121069 г. Москва, Россия. ORCID ID: https://orcid.org/0000-0002-9925-5585

E-mail: mar-mozharova@yandex.ru

Дата поступления статьи в редакиию: 16.01 .2021

Дата одобрения статьи рецензентами: 05.03 .2021

Дата публикации статьи: 28.06.2021

Для циттирования: Можарова М. А. «Основной бас»: к истории одного музыкального образа в романе Л. Н. Толстого «Анна Каренина» // Два века русской классики. 2021. Т. 3, № 2. С. 186-201. https://doi.org/10.22455/2686-7494-2021-3-2-186-201 


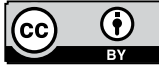

This is an open access article distributed under the Creative Commons Attribution 4.0 International (CC BY 4.0)
Dva veka russkoi klassiki, vol. 3, no. 2, 2021, pp. 186-201. ISSN 2686-7494

Two centuries of the Russian classics, vol. 3, no. 2, 2021, pp. 186-201. ISSN 2686-7494

Research Article

(C) 2021. Marina A. Mozharova

A. M. Gorky Institute of World Literature of the Russian Academy of Sciences

Moscow, Russia

\title{
"Thorough Bass": on the History of a Musical Image in L. N. Tolstoy's Novel Anna Karenina
}

\begin{abstract}
The article deals with the history of a musical term, transformed by L. N. Tolstoy in his novel Anna Karenina into imagery employed for the conveying of ideas about running farmlands in Russia, which are so important for the author and his character Konstantin Levin. Having chosen a musical term to express his idea in the most accurate way, Tolstoy draws parallels between various narrative arcs and certain parts in a polyphonic composition where the main role is that of the "thorough bass" which is Levin's impressions of the household of an old and wise peasant. Quite expectable of the writer, who loved and studied music, this artistic solution seemed to be so unusual to the editors preparing the publications of Anna Karenina during the entire $20^{\text {th }}$ century that they considered it to be a misspell of a copying clerk or a type setter. As a result, a polysemic musical term "thorough bass" was replaced by "fundamental basis". Looking up in the autographs does not give the answer to the question, which of these two options is correct, as manuscript collection has not been fully preserved. The only formal source which allows a textual critic to reconstruct the initial version is the text of the first publication of the novel in the magazine Russky Vestnik (1875-1877) corrected by Tolstoy himself in 1877, in accordance with which Anna Karenina is being published in academic Complete works of L. N. Tolstoy in 100 volumes.

Keywords: L. N. Tolstoy, Anna Karenina, textual criticism, artistic creation, musical term, text history, preparation of the publication.
\end{abstract}

Information about the author: Marina $\mathrm{A}$. Mozharova, $\mathrm{PhD}$ in Philology, Senior Researcher, A. M. Gorky Institute of World Literature of the Russian Academy of Sciences, Povarskaya 25 a, 121069 Moscow, Russia.

ORCID: https://orcid.org/0000-0002-9925-5585

E-mail: mar-mozharova@yandex.ru

Received: January 11, 2021

Approved after reviewing: March 05, 2021

Published: June 28, 2021

For citation: Mozharova, M. A. “'Thorough Bass': on the History of a Musical Image in L. N. Tolstoy's Novel Anna Karenina." Dva veka russkoi klassiki, vol. 3, no. 2, 2021, pp. 186-201. (In Russ.) https://doi.org/10.22455/2686-7494-2021-3-2-186-201 
Необыкновенная музыкальность Л. Н. Толстого неизменно отмечалась мемуаристами, биографами и исследователями его творчества. Очерк «Музыка в жизни моего отца» старший сын писателя С. Л. Толстой начал словами: «Я не встречал в своей жизни никого, кто бы так сильно чувствовал музыку, как мой отец» [Толстой С. Л.: 393]. Неудивительно, что 19-летний Л. Н. Толстой включил музыку в свою обширную программу самостоятельного обучения наряду с курсом юридических наук, иностранными языками, историей, географией, статистикой, математикой, теоретическим и практическим сельским хозяйством, медициной и гимнастикой. В дневнике 17 апреля 1847 г. он сформулировал это так: «Достигнуть средней степени совершенства в музыке и живописи» [Толстой 1937: 31].

В январе 1858 г. Толстой был захвачен идеей создания в Москве музыкального общества, руководство которого взял на себя пианист Л. Мортье [Гусев: 175]. Лев Николаевич собственноручно написал проект учреждения общества и обсуждал его с Н. Г. Рубинштейном. Впоследствии этот замысел был осуществлен братьями Рубинштейнами, основавшими в 1859 г. Русское музыкальное общество, получившее в 1869 г. статус Императорского.

Пианист и композитор А. Б. Гольденвейзер, много общавшийся с Толстым, писал, что у Льва Николаевича в молодости были «периоды страстного увлечения музыкой, когда он часами занимался игрой на фортепиано и даже, по-видимому, слегка мечтал стать музыкантом» [Гольденвейзер: 592]. А. Б. Гольденвейзер упомянул и о важной стороне этого увлечения - о серьезном изучении Толстым теории музыки. Без учета этого факта исследование художественных особенностей произведений писателя будет неполным. Занятия теорией музыки сказались уже в ранних толстовских сочинениях. На эту особенность творческого процесса писателя обратил внимание Б. М. Эйхенбаум: «Толстой недаром занимался музыкой: в конструкции многих его вещей можно 
наблюдать аналогии музыкальным формам». Исследователь приводит в пример рассказ «Севастополь в мае», где, по его словам, «впервые появляется нечто вроде интродукции, позже так оригинально использованной в “Двух гусарах", а затем и в “Декабристах”. Эта интродукция, ярко окрашенная ораторскими приемами, нужна Толстому для того, чтобы следующее затем сообщение фактов, лишенное всякой лирики и всякой торжественности, звучало не само по себе, а на фоне предыдущего» [Эйхенбаум: 234].

Многие художественные произведения Толстого наполнены описаниями звучащей музыки и воздействия ее на героев. Так, в «Альберте» музыка стала самостоятельным действующим лицом. Музыкальные звуки в повести не просто звучат, они разговаривают, вступают в диалог с героями. Богатство метафорических эпитетов к слову «звук» помогло Толстому создать многочисленные смысловые пласты повествования [Можарова 2014]. В «Войне и мире» музыкальные впечатления и музыкальные образы, возникающие в сознании героев, ярко характеризуют их внутренний мир. В «Крейцеровой сонате» музыкальная тема особенно важна, здесь она стала самостоятельным средством выражения авторского замысла.

В период создания романа «Анна Каренина» Толстой, по воспоминаниям его сына, увлекался музыкой до того, что проводил за роялем «по три-четыре часа в день» [Толстой С. Л.: 400]. Нередко он с женой Софьей Андреевной «с удовольствием играл в четырехручном изложении симфонии и квартеты Гайдна, а также симфонии Моцарта и Шуберта, увертюры Вебера и пр.» [Толстой С. Л.: 412]. Музыкальная атмосфера толстовского дома, общение писателя с выдающимися композиторами и исполнителями (в 1876 г., например, Н. Г. Рубинштейн познакомил Толстого с П. И. Чайковским) нашли отражение в музыкальном контексте создаваемого в это время романа.

Обратимся лишь к одному эпизоду в «Анне Карениной», которому Толстой отвел роль главной темы в многоголосном повествовательном контексте, напоминающем звучание полифонического музыкального произведения.

В третьей части романа (главы XXIV-XXX) рассказывается о постигшем Константина Левина разочаровании в способах ведения собственного хозяйства; о вызванной душевным неустройством поездке к Свияжскому и обсуждении в его доме волновавших Левина тем, и 
прежде всего - новых отношений помещиков с крестьянами, ставшими в пореформенной России наемными работниками. В главе XXV описана недолгая остановка Левина в доме богатого мужика и рассказано о сильном впечатлении, произведенном на него процветающим крестьянским хозяйством.

Сближение Левина с мужиками, «зависть, которую он испытывал к ним, к их жизни, желание перейти в эту жизнь» стали главной причиной того, что собственное хозяйство Левина «опротивело ему и потеряло для него всякий интерес» [Толстой 2020: 304]. Левин «ясно видел теперь, что то хозяйство, которое он вел, была только жестокая и упорная борьба между им и работниками, в которой на одной стороне, на его стороне, было постоянное напряженное стремление переделать все на считаемый лучшим образец, на другой же стороне - естественный порядок вещей» [Толстой 2020: 304]. Другим обстоятельством, лишившим Левина душевного покоя, было присутствие в тридцати верстах от него вернувшейся из-за границы Кити Щербацкой, «которую он хотел и не мог видеть» [Толстой 2020: 305]. Мимолетная встреча с Кити не оставила в Левине сомнений в том, что «он не переставал любить ее». Но то, что «он сделал ей предложение и она отказала ему, клало между им и ею непреодолимую преграду» [Толстой 2020: 306]. Убегая от «опостылевшего хозяйства» и стремясь заглушить душевную боль привычным и испытанным способом - охотой, Левин отправился в дальний Суровский уезд по приглашению своего приятеля Свияжского, в имении которого были прекрасные дупелиные болота. На полпути Левин сделал остановку в доме богатого крестьянина, хозяйство которого поразило его своей благоустроенностью.

Поместив непосредственно за рассказом о нестроениях в имении Левина описание благополучного крестьянского хозяйства, Толстой прибег к одному из основных своих приемов, названному В. А. Ждановым «одновременностью действия контрастирующих сюжетных линий» [Жданов: 208], и тем самым усилил эффект воздействия обеих картин. Невольно сравнивая порядки, установленные мужиком, с ходом дел в своем имении, Левин убеждался в превосходстве крестьянского ведения хозяйства. Например, картофель у старика «уже отцветал и завязывался, тогда как у Левина только зацветал» [Толстой 2020: 308]; прополонную рожь бережно собирали и кормили ею лошадей, а у Левина этот прекрасный корм пропадал, хотя он хотел собирать его, 
но это всегда оказывалось невозможным. Все это и многое другое, увиденное Левиным, указывало на то, что хозяйство старика процветало. На большом и чистом дворе и в ухоженном доме царил порядок; лошади были сытые и крупные. Из разговора с хозяином Левин узнал, что «он был и не прочь от нововведений»: кроме своих семейных работников, у старика были и наемные. Старик был «справедливо горд своим благосостоянием, горд своими сыновьями, племянником, невестками, лошадьми, коровами и в особенности тем, что держится все это хозяйство». На замечание Левина: «А вот у нас, помещиков, все плохо идет с работниками» - старик ответил: «Наше дело мужицкое. Мы до всего сами» [Толстой 2020: 308].

Впечатление благоустройства, произведенное на Левина хозяйством и семейством богатого крестьянина, «было так сильно, что Левин никак не мог отделаться от него. И всю дорогу от старика до Свияжского нет-нет и опять вспоминал об этом хозяйстве, как будто что-то в этом впечатлении требовало его особенного внимания» [Толстой 2020: 309]. Завершая этими словами главу о пребывании Левина в доме богатого мужика, Толстой наметил лейтмотив последующего повествования и указал на важную как для его героя, так и для него самого тему устройство земледельческого хозяйства в России.

Отражение переломного этапа в истории России сопряжено в романе с описанием кризисного периода в личной жизни Левина. Переплетение этих тем прослеживается не только в композиционном и образном построении романа, но и на лексическом уровне. Так, в рассматриваемых главах особую смысловую нагрузку несет на себе слово «теперь», часто повторяющееся в авторском комментарии: «Теперь, после своего разочарования в хозяйстве, Левину особенно приятно было побывать у Свияжского <...> ему хотелось теперь, чувствуя себя столь недовольным своею жизнью, добраться в Свияжском до того секрета, который давал ему такую ясность, определенность и веселость в жизни» [Толстой 2020: 310-311]. Левин знал, что у Свияжского, ведшего усовершенствованное хозяйство и представлявшего собой «самый лучший тип земского деятеля» [Толстой 2020: 309], он встретит помещиков-соседей; «ему теперь особенно интересно было поговорить, послушать о хозяйстве те самые разговоры об урожае, найме рабочих и т. п., которые, Левин знал, принято считать чем-то очень низким, но которые теперь для Левина казались одними важными» [Толстой 2020: 311]. 
Размышляя о переходном характере эпохи, определившем изменение условий хозяйствования, Левин сосредоточился на главной для него мысли: «У нас теперь, когда все это переворотилось и только укладывается, вопрос о том, как уложатся эти условия, есть только один важный вопрос в России» [Толстой 2020: 311]. В этих раздумьях Левин особенно близок к автору. «Чем бы ни занимался Толстой, - писал В. Ф. Асмус, - что бы он ни изображал в своих романах, пьесах, рассказах, какие бы трактаты он ни писал, - во всех них он пытался уяснить себе один вопрос, который представлялся ему самым важным вопросом истории. Это вопрос о том, в каком направлении идет перестройка русской жизни, начавшаяся с освобождения крестьян в 1861 году» [Асмус: 41]. В пореформенной России все «переворотилось» не только в хозяйствах помещичьих усадеб, но «все смешалось» и в нравственной жизни дворянских семейств, как, например, у Облонских и Карениных. Данная Левиным характеристика пореформенной России выполняет ключевую роль в раскрытии идейной и художественной структуры «Анны Карениной». Формулу «все смешалось» Э. Г. Бабаев назвал «лаконичной и многозначной», представляющей собой «тематическое ядро романа» [Бабаев: 8-9].

Ответ на главный вопрос эпохи - как должны «уложиться» новые условия жизни - Толстой искал в народной среде. Писатель, по словам В. Ф. Асмуса, «глядел на русскую жизнь глазами патриархального крестьянина» [Асмус: 43]. То же стремление прослеживается и у Константина Левина. Не случайно впечатление от семьи и хозяйства умудренного жизнью крестьянина неотступно сопровождает толстовского героя: «И на охоте, в то время когда он, казалось, ни о чем не думал, нет-нет и опять ему вспоминался старик со своею семьей, и впечатление это как будто требовало к себе не только внимания, но и разрешения чего-то с ним связанного» [Толстой 2020: 311].

Из разноголосицы суждений, услышанных в доме Свияжского, Левин уяснил для себя, что «то недовольство хозяйством, которое он теперь испытывал, есть не исключительное его положение, а общее условие, в котором находится дело в России» [Толстой 2020: 317]. Перебирая в памяти впечатления от встречи со старым крестьянином и разговоры помещиков, Левин, мысленно продолжая диалог со Свияжским, утверждавшим, что мужики ненавидят все усовершенствования и что их надо вводить властью, возражал ему: «Мы давно уже ломим 
по-своему, по-европейски, не спрашиваясь о свойствах рабочей силы. Попробуем признать рабочую силу не идеальною рабочею силой, а русским мужиком с его инстинктами и будем устраивать сообразно с этим хозяйство» (курсив источника. - М. М.) [Толстой 2020: 320]. Левин ясно видел, что хозяйство «идет только там, где рабочий действует сообразно с своими привычками, как у старика на половине дороги» [Толстой 2020: 320].

Убеждение, что главным элементом хозяйства является рабочая сила, утвердило Левина в мысли, что «устройство какого-нибудь такого отношения рабочих, где бы они работали, как у мужика на половине дороги, есть не мечта, а задача, которую необходимо решить» [Толстой 2020: 317]. И Левину казалось, что задачу эту можно и должно решить. Он ясно видел, что «Россия имеет прекрасные земли, прекрасных рабочих и что в некоторых случаях, как у мужика на половине дороги, рабочие и земля производят много, в большинстве же случаев, когда по-европейски прикладывается капитал, производят мало, и что происходит это только оттого, что рабочие хотят работать и работают хорошо одним им свойственным образом, и что это противодействие не случайное, а постоянное, имеющее основания в духе народа» [Толстой 2020: 324]. Возвратившись домой, Левин задумал в своем хозяйстве на практике доказать ценность крестьянских приемов хозяйствования и написать книгу, которая должна была «положить начало новой науке об отношениях народа к земле» [Толстой 2020: 324].

Итак, Толстой в конце XXV-ой главы говорит о том, что впечатление от дома и благоустроенного хозяйства богатого мужика «было так сильно, что Левин никак не мог отделаться от него» [Толстой 2020: 309]. В следующих главах писатель показывает воздействие этого впечатления на мысли своего героя и на его решение «перевернуть все прежнее хозяйство» [Толстой 2020: 320]. Своеобразным итогом многократного возвращения к воспоминанию о старике крестьянине можно считать появление в авторском комментарии (гл. XXVIII) образа, наиболее ярко передающего значение этой встречи для Левина: «Все впечатления этого дня, начиная с впечатления мужика на половине дороги, которое служило как бы основным басом всех нынешних впечатлений и мыслей, сильно взволновали Левина» [Толстой 2020: 319]. Избрав музыкальный термин «основной бас» для наиболее точного выражения своей мысли, Толстой уподобляет различные темы повествования 
(недовольство хозяйством, отношения с Кити, споры с помещиками о рабочей силе, беспокоящее Левина общее положение дел в России) отдельным голосам в полифоническом произведении, где роль главного голоса отведена «впечатлению мужика на половине дороги».

«Основной бас» - образ необычный, но вполне закономерный для Толстого-художника, в творчестве которого, по словам, В. В. Виноградова, наряду со стилистическими формами литературного «аристократического» языка и областными диалектами существовала также «широкая система профессиональных диалектов, игравших громадную роль в обиходе дворянского быта» [Виноградов: 134]. Что же означает музыкальный термин «основной бас»? Объяснение находим в современном Толстому музыкальном словаре: «Основной бас бывает тогда, когда мы к каждому аккорду в сочинении приискиваем еще один главный тон, на котором непосредственно основывался бы весь аккорд» [Михельсон: 172]. Основной бас называли также генерал-басом и грунт-басом (от нем. и фр. grund - основание, basse - бас) [Михельсон: 141,172$]$. Существуют и другие синонимичные названия - общий бас и непрерывный бас: basso generale, basso continuo (итал.), basse fondamentale ( $ф р$.$) , fundamental bass, thorough bass (англ.). Возникно-$ вение этого термина в европейской музыке связано с появившимся в конце XVI - начале XVII вв. способом записи многоголосных сочинений, который заключался в фиксации лишь нижнего голоса (баса), а остальные звуки записывались цифрами, означающими интервалы от баса. Представленные в таком виде для певцов партии отдельных голосов позволяли композиторам скрывать полные партитуры их сочинений ради сохранения профессиональных секретов.

Созданный Толстым музыкальный образ присутствует в первой публикации «Анны Карениной» в журнале «Русский вестник» (18751877): «Все впечатления этого дня, начиная с мужика на половине дороги и бабы в калошках, которое служило как бы основным басом всех нынешних впечатлений и мыслей, сильно взволновали Левина» [Толстой 1876: 373]. Исправляя текст романа для нового издания 1878 г., Толстой вычеркнул слова «и бабы в калошках», исключив упоминание о «чисто одетой молодайке в калошках на босу ногу» и усилив тем самым значение воспоминания о старике и его хозяйстве [Толстой 1876: 357]. Одновременно с автором в тот же печатный экземпляр романа множество стилистических, орфографических и пунктуационных по- 
правок внес Н. Н. Страхов, привлеченный Толстым к просмотру текста. В рассматриваемую фразу Страхов добавил слово «впечатление». В результате фрагмент стал таким: «Все впечатления этого дня, начиная с впечатления мужика на половине дороги, которое служило как бы основным басом всех нынешних впечатлений и мыслей, сильно взволновали Левина» ${ }^{1}$. В таком виде эта фраза напечатана в отдельном издании романа 1878 г. [Толстой 1878: 162], для которого исправленный журнальный текст послужил наборной рукописью.

Редакторы 90-томного (Юбилейного) издания Полного собрания сочинений Л. Н. Толстого (1928-1958) впервые после 1878 г. подвергли критическому анализу текст «Анны Карениной», проделав огромную работу по освобождению его от ошибок, допущенных копиистами и наборщиками. Л. Д. Громова-Опульская писала об этом издании, что оно «настолько значительно и монументально, что мы продолжаем гордиться им» [Громова-Опульская: 450]. Однако не со всеми текстологическими решениями, принятыми в этом издании, можно согласиться. К их числу относится исправление «основным басом» на «основным базисом»: «Все впечатления этого дня, начиная с впечатления мужика на половине дороги, которое служило как бы основным базисом всех нынешних впечатлений и мыслей, сильно взволновали Левина» [Толстой 1934: 356]. Сложно предположить, чем было вызвано изменение выбранного Толстым музыкального термина на далекое от музыки тавтологическое словосочетание «основной базис»: basis (греч.) - основа, основание, опора, фундамент, база. Рукописный фонд «Анны Карениной» не дает оснований для такой замены, так как ни автограф этого фрагмента, ни наборная рукопись третьей части романа не сохранились. Возможно, редакторы Юбилейного издания сочли слово «бас» ошибкой переписчика или опечаткой.

Редакторы последовавших за 90-томником столь же авторитетных изданий, в которых была продолжена работа по восстановлению авторского текста «Анны Карениной», тоже, к сожалению, отказались печатать «основным басом». В издании романа 1970 г. (серия «Литературные памятники») читаем: «Все впечатления этого дня, начиная с мужика на половине дороги, которое служило как бы основным базисом всех нынешних впечатлений и мыслей, сильно взволновали Левина» [Толстой 1970: 287-288]. Как и в Юбилейном издании, «бас» здесь

${ }^{1}$ ОР ГМТ. Ф. 1. «Анна Каренина». Оп. 139. Л. 388. 
исправлен на «базис». Но правка этим не ограничилась: вопреки публикациям XIX в. и 90-томнику редакторы этого издания отказались от поправки Страхова, убрав вставленное им слово «впечатления». Точно так же напечатали эту фразу и в 22-томном Собрании сочинений Л. Н. Толстого (1978-1985), исправив «основным басом» на «основным базисом» и отвергнув поправку Страхова [Толстой 1981: 372]. Таким образом, созданный автором значимый музыкальный образ исчез из текста «Анны Карениной».

Многочисленные современные издания переводов «Анны Карениной» на иностранные языки воспроизводят либо текст Юбилейного издания (со вставленным Страховым словом «впечатления»), либо текст «Литературных памятников» (без поправки Страхова), «основной бас» в этих изданиях отсутствует. Исключением является английский перевод К. Гарнет (Constance Garnett). Переводчица абсолютно правильно передала не только смысл толстовской фразы, но и сохранила музыкальный подтекст: "All the impressions of the day, beginning with the impression made by the old peasant, which served, as it were, as the thorough-bass of all the conceptions and ideas of the day, threw Levin into violent excitement" [Anna Karenina 1933: 369] (Здесь и далее выделено нами. - M. M.). По тому, что поправка Страхова в этом переводе присутствует, можно заключить, что источником для перевода могло послужить издание 1878 г. В переизданиях перевода К. Гарнет «основной бас» издателями сохранялся [Anna Karenina 1952: 393].

В других переводах музыкальная составляющая толстовской фразы отсутствует. Например, в американском издании (перевод Р. Певера и Л. Волохонской): "All the impressions of that day, starting with the muzhik half-way there, which seemed to serve as the fundamental basis for all that day's impressions and thoughts, stirred Levin deeply" [Anna Karenina 2002: 337-338]. Источником для этого перевода послужило издание 1970 г., на это указывает отсутствие во фрагменте поправки Страхова. В первом переводе «Анны Карениной» на итальянский язык, осуществленном Львом Гинзбургом в 1929 г., а также в его переизданиях «основного баса» нет: “Tutte le impressioni di quella giornata, a cominciare dall'impressione del mužik a mezzo della strada che serviva come da base fondamentale di tutte le impressioni e di tutti i pensieri del giorno, avevano fortemente agitato Lévin" (курсив источника. - М. М.) [Anna Karenina 2005: 374]. Современники Толстого Луиза и Эйлмер 
Моод тоже отказались от «основного баса», выбрав «фундамент», «основание»: "All the impressions of the day, beginning with the impression of the peasant at the half-house which seemed to serve as a foundation for all the other impressions and ideas, agitate Levin greatly" [Anna Karenina 2017: 466]. В переводе на немецкий язык, источником которого послужило издание «Литературных памятников» (1970), тоже, по понятной причине, находим только «основу», «базис»: "Alle Eindrücke dieses Tages, angefangen von dem Bauern auf halbem Weg, der gleichsam für alle jüngsten Eindrücke und Gedanken die Grundlage abgab, hatten Lewin stark erregt" [Anna Karenina 2009: 513]. Точным переводом на немецкий язык музыкального термина «основной бас» было бы “Bezifferter Bass” [Энциклопедический словарь 8: 313].

Отдельного упоминания заслуживает новый перевод на итальянский язык Лауры Салмон: “Tutte le impressioni di quella giornata, a partire dal contadino incontrato in viaggio, che aveva constituito una sorta di fondamento per tutte le impressioni e i pensieri di quel giorno, agitavano Levin profondamente" [Anna Karenina 2004: 972]. Казалось бы, этот вариант перевода можно причислить к многочисленной группе переводов, в которых отсутствует поправка Страхова и выбрано слово «фундамент», «основание». Но особенность итальянского слова "fondamento" состоит в том, что оно является также музыкальным термином и означает «басовую партию в многоголосии» [Словарь: 62]. В Энциклопедическом словаре Ф. А. Брокгауза и И. А. Ефрона приведено два итальянских аналога генерал-баса: "Fondamento" и "Basso continuo” [Энциклопедический словарь 8: 313]. Не беремся судить, какими соображениями руководствовалась Л. Салмон, но так или иначе в ее переводе вновь зазвучала музыкальная тема, и фразе Толстого был возвращен изначально заложенный в нее смысл.

В академическом Полном собрании сочинений Л. Н. Толстого в 100 томах $($ т. 11, 2020) текст этого фрагмента восстановлен по исправленному писателем в 1877 г. экземпляру «Русского вестника», избранному в качестве основного источника для публикации романа «Анна Каренина»: «Все впечатления этого дня, начиная с впечатления мужика на половине дороги, которое служило как бы основным басом всех нынешних впечатлений и мыслей, сильно взволновали Левина» [Толстой 2020: 319]. При отсутствии автографа и рукописей, которые могли бы подтвердить, что «основным басом» написано рукой Толстого, 
печатный текст «Русского вестника», в котором писатель оставил без изменений это словосочетание, зачеркнув только «и бабы в калошках» и согласившись с поправкой Страхова, становится не менее авторитетным источником для принятия текстологических решений. Да и опубликованный в 1933 г. перевод К. Гарнет служит весомым аргументом того, что «основной бас» (thorough bass), верно воспринятый переводчицей как музыкальный термин, не является ошибкой или опечаткой. Таким образом, возвращение в текст «Анны Карениной» музыкального образа восстанавливает художественную структуру важнейшего эпизода романа.

В последний год жизни Толстого его секретарь В. Ф. Булгаков записал слова писателя: «Люблю музыку больше всех других искусств, мне всего тяжелее было бы расстаться с ней» [Булгаков: 147]. Это признание помогает понять, отчего в произведениях Толстого, еще с повести «Детство», положившей начало его пути в литературе в 1852 г., до повести «Хаджи-Мурат», опубликованной уже посмертно в 1912 г., неизменно присутствует музыка. Проявляя себя явно и неявно в описаниях впечатлений, чувств и мыслей героев, в авторских комментариях и композиционных построениях, музыкальный контекст несет в себе огромную смысловую нагрузку и расширяет горизонты художественного пространства произведений Толстого. Не случайно С. Л. Толстой упомянул, что его отец «действительно знал почти все, что было выдающегося в музыке в его эпоху» [Толстой С. Л.: 406-407]. Любовь к музыке, пронесенная через всю жизнь, обусловила естественную для Толстого-художника способность мыслить музыкальными категориями. Оттого и осуществилось в «Анне Карениной», в связи с самым близким для Толстого героем романа - Константином Левиным, превращение музыкального термина в художественный образ, наделенный важной ролью объединительного центра в многоголосном повествовательном контексте. 


\section{Список литературы \\ Источники}

Булгаков В. Ф. Л. Н. Толстой в последний год его жизни. М.: Правда, 1989. 448 с.

Гольденвейзер А. Б. Толстой и музыка. Из воспоминаний А. Б. Гольденвейзера // Литературное наследство. М.: Изд-во АН СССР, 1939. Т. 37/38: Л. Н. Толстой. Кн. 2. C. 591-594.

Гусев Н. Н. Летопись жизни и творчества Льва Николаевича Толстого. 18281890. М.: Худож. лит., 1958. 840 с.

Михельсон А. Д. Объяснение 25000 иностранных слов, вошедших в употребление в русский язык, с означением их корней. М.: А. И. Манухин, 1865. 718 с.

Словарь иностранных музыкальных терминов / сост. Т. Крунтяева, Н. Молокова, А. Ступель. Изд. 2-е, доп. Л.: Музыка, 1977. 152 с.

Толстой Л. Н. Анна Каренина. Часть третья. Главы XI-XXVIII // Русский вестник. 1876. Кн. I. С. 305-390.

Толстой Л. Н. Анна Каренина: в 3 т. М.: Тип. Т. Рис, 1878. Т. 2. 493 с.

Толстой Л. Н. Анна Каренина / Серия «Литературные памятники». М.: Наука, 1970. 912 c.

Толстой Л. Н. Полн. собр. соч.: в 90 т. М.: Худож. лит., 1928-1958. Т. 18. 1934. $557 \mathrm{c}$.

Толстой Л. Н. Полн. собр. соч.: в 90 т. М.: Худож. лит., 1928-1958. Т. 46. 1937. $576 \mathrm{c}$.

Толстой Л. Н. Полн. собр. соч.: в 100 т. М.: Наука, 2000- (изд. продолжается). T. 11.2000 .414 c.

Толстой Л. Н. Собр. соч.: в 22 т. М.: Худож. лит., 1978-1985. Т. 8. 1981. 495 с.

Толстой С. Л. Очерки былого. Тула: Приокское книжное изд-во, 1965. 512 с.

Энциклопедический словарь: в 86 т. / под ред. Ф. А. Брокгауз, И. А. Ефрон. СПб.: Семеновская Типо-литогр. (И. А. Ефрона), 1890-1907.

Anna Karenina: two vol. / By Leo Tolstoy; trans. by Constance Garnett, with an introd. by A. Lunacharsky. Moscow: Goznak press, 1933. Vol. 1. 476 p.

Anna Karenina / By Leo Tolstoy; trans. by Constance Garnett. New York: Heritage press, $1952.935 \mathrm{p}$.

Anna Karenina: a novel in eight parts / By Leo Tolstoy; trans. by Richard Pevear and Larissa Volokhonsky. [Newark, N. J.] Penguin Books, 2002. 838 p.

Anna Karenina / Lev Tolstoy; traduz. di Laura Salmon. Roma: Gruppo Editoriale L'Espresso SpA-Divisione La Repubblica, 2004. 972 p.

Anna Karenina / Lev Tolstoy; traduz. di Leone Ginzburg; prefaz. di Natalia Ginzburg. Torino: Einaudi, 2005. 887 p.

Anna Karenina: roman in acht Teilen / Lew Tolstoi; übersetzt und kommentiert von Rosemarie Tietze. München: Carl Hanser Verlag, 2009. 1285 s.

Anna Karenina / By Leo Tolstoy; transl. by Louise and Aylmer Maude; afterword by Ned Halley. London: Macmillan Collector's Library: New York, 2017. 1127 p. 


\section{Исследования}

Асмус В. Ф. Мировоззрение Толстого // Асмус В. Ф. Избранные философские труды: в 2 т. М.: Изд-во Московского ун-та, 1969. Т. 1. С. 40-101.

Бабаев Э. Г. «Анна Каренина» Л. Н. Толстого. М.: Худож. лит., 1978. 158 с.

Виноградов В. В. О языке Толстого (50-60-е годы) // Литературное наследство. М: Изд. АН СССР, 1939. Т. 35. С. 117-220.

Громова-Опульская Л. Д. Избранные труды. М.: Наука, 2005. 530 с.

Жданов В. А. Творческая история «Анны Карениной». М.: Сов. писатель, 1957. $264 \mathrm{c}$.

Можарова М. А. Метафорические эпитеты к слову «звук» в повести Л. Н. Толстого «Альберт» // Толстой сегодня. Материалы Толстовских чтений 2012. М.: Оригинал-макет, 2014. С. 15-22.

Эйхенбаум Б. М. Лев Толстой. Книга первая: Пятидесятые годы // Эйхенбаум Б. М. Лев Толстой: Исследования. Статьи. СПб.: Факультет филологии и искусств СПбГУ, 2009. С. 145-353. 


\section{References}

Asmus, V. F. "Mirovozzrenie Tolstogo" ["Tolstoy's Philosophy of Life"]. Asmus, V. F. Izbrannye filosofskie trudy: $v 2$. [Selected Philosophical Works: in 2 vols.], vol. 1. Moscow, Izdatel'stvo Moskovskogo universiteta Publ., 1969, pp. 40-101. (In Russ.)

Babaev, E. G. "Anna Karenina" L.N. Tolstogo ["Anna Karenina" by L. N. Tolstoy]. Moscow, Khudozhestvennaia Literatura Publ., 1978. 158 p. (In Russ.)

Vinogradov, V. V. "O iazyke Tolstogo (50-60-e gody)" ["On Tolstoy's Language (5060s)"]. Literaturnoe nasledstvo [Literary Heritage], vol. 35. Moscow, Izdatel'stvo AN SSSR Publ., 1939, pp. 117-220. (In Russ.)

Gromova-Opul'skaia, L. D. Izbrannye Trudy [Selected Works]. Moscow, Nauka Publ., 2005. 530 p. (In Russ.)

Zhdanov, V. A. Tvorcheskaia istoriia "Anny Kareninoi" [Creative History of "Anna Karenina"]. Moscow, Sovetskii pisatel' Publ., 1957. 264 p. (In Russ.)

Mozharova, M. A. "Metaforicheskie epitety k slovu 'zvuk' v povesti L. N. Tolstogo 'Al'bert."' ["Metaphorical Epithets of the Word 'Sound' in L. N. Tolstoy's Short Novel Albert"]. Tolstoi segodnia. Materialy Tolstovskikh chtenii $2012 \mathrm{~g}$. [Tolstoy Today. Materials of the Tolstoy Proceedings 2012]. Moscow, Original-maket Publ., 2014, pp. 15-22. (In Russ.)

Eikhenbaum, B. M. Lev Tolstoi. Kniga pervaia: Piatidesiatye gody [Leo Tolstoy. Book One: The Fifties]. Eikhenbaum, B. M. Lev Tolstoi: Issledovaniia. Stat'i [Leo Tolstoy: Studies. Articles]. St. Petersburg, Fakul'tet filologii i iskusstv SpbGU Publ., 2009, pp. 145-353. (In Russ.) 


\section{Похвальба и позитивная самооценка в пьесах А. П. Чехова}

Аннотация: В настоящей статье теория речевых актов применяется к рассмотрению использования и функционирования похвальбы/позитивной самооценки в текстах трех пьес А. П. Чехова: «Чайка», «Три сестры» и «Вишневый сад». Анализ проводился с помощью ручного кодирования речевых актов похвальбы/позитивной самооценки, результаты его демонстрируют, что данный речевой акт использовался Чеховым в разных текстуальных функциях для обрисовки характеров действующих лиц. В частности, похвальба применяется как литературный прием описания персонажей, которые по замыслу автора нравятся зрителю/читателю меньше, а также для предоставления возможности другим персонажам постоять за себя против несправедливого отношения или провокаций. Похвальба/позитивная самооценка включает формы смягчения и отягчения. Смягчение достигается в основном при помощи грамматических или фразовых средств, а также семантически через самокритику/ самоуничижение. Отягчение достигается преимущественно также грамматическими и фразовыми средствами. Единственный семантический прием отягчения, обнаруженный в текстах, представляет собой критику или уничижение других персонажей. Специфические формы позитивной самооценки в чеховских пьесах - это лингвистическая похвальба, контекстно необоснованные переходы на французский и латинский, а также похвала своему поколению (последняя форма представлена в драме «Три сестры»). Результаты свидетельствуют, что исследования речевых актов в пьесах могут быть продуктивны для теории литературы, они уточняют разработку персонажей и мастерство драматурга.

Ключевье слова: А. П. Чехов, речевые акты, похвальба, положительная самооценка, драматургические персонажи, текстовый анализ, «Чайка», «Три сестры», «Вишневый сад».

Информация об авторе: Вероника Анатольевна Макарова, кандидат филологических наук, профессор кафедры языкознания Саскачеванского университета, к. 914, 9 Кэмпус Драйв, здание Искусств, Саскатун, Саскачеван, Канада.

ORCID ID: https://orcid.org/0000-0003-1885-0989

E-mail: v.makarova@usask.ca

Дата поступления статьи в редакиию: 18.02 .2021

Дата одобрения статьи рецензентами: 07.04 .2021

Дата публикации статьи: 28.06.2021

Для цичтирования: Макарова В. А. Похвальба и позитивная самооценка в пьеcax А. П. Чехова // Два века русской классики. 2021. Т. 3, № 2. С. 202-229. https://doi.org/10.22455/2686-7494-2021-3-2-202-229 


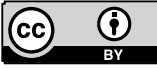

This is an open access article distributed under the Creative Commons Attribution 4.0 International (CC BY 4.0)
Dva veka russkoi klassiki,

vol. 3, no. 2, 2021, pp. 202-229. ISSN 2686-7494

Two centuries of the Russian classics, vol. 3, no. 2, 2021, pp. 202-229. ISSN 2686-7494

Research Article

(C) 2021. Veronika A. Makarova

University of Saskatchewan, Saskatoon, Saskatchewan, Canada

\section{Self-praise and Positive Self-assessment in Chekhov's Plays}

Abstract: This paper applies Speech Act Theory towards an investigation of the use and role of self-praise/positive self-assessment in the texts of three Chekhov's plays: The Seagull, Three Sisters and The Cherry Orchard. The findings conducted with manual coding of texts for the speech acts of self-praise/positive self-assessment suggest that Chekhov employed self-praise for a number of textual and character-building functions. In particular, selfpraise functions as a literary device to identify less likable characters as well as to provide a chance for more likable characters to stand up for themselves against injustice and provocation. The self-praise/positive self-assessment comes in mitigated and aggravated forms. Mitigation is mostly achieved through grammatical or phrasal means, as well as semantically through self-criticism, whereby the only form of aggravation observed in the data was other-criticism/other-derogation. Specific forms of a positive self-assessment likely unique to Chekhov's plays are 'linguistic brags', i.e., contextually unjustifiable switches to French and Latin as well as 'generational' positive self-representation in Three Sisters. The results suggest that investigations of speeh acts in dramas could be productive for literary theory, as they shed more light on the characters development as well as the genre mastery of the playwright.

Keywords: Anton Chekhov, speech acts, self-praise, positive self-assessment, drama characters, text analysis, The Seagull, Three Sisters, The Cherry Orchard.

Information about the author: Veronika A. Makarova, $\mathrm{PhD}$ in Philology, Professor of the Department of Linguistics, University of Saskatchewan, Room 914, 9 Campus Drive, Arts Building, 9 Campus Drive, Saskatoon, Saskatchewan, Canada.

ORCID ID: https://orcid.org/0000-0003-1885-0989

E-mail:v.makarova@usask.ca

Received: February 18, 2021

Approved after reviewing: April 07, 2021

Published: June 28, 2021

For citation: Makarova, V. A. "Self-praise and Positive Self-assessment in Chekhov's Plays." Dva veka russkoi klassiki, vol. 3, no. 2, 2021, pp. 202-229. (In Russ.)

https://doi.org/10.22455/2686-7494-2021-3-2-202-229 


\section{Introduction and literature review}

This paper investigates the use of self-praise/positive self-assessment speech act in the texts of three Chekhov's plays: The Seagull, Three Sisters and The Cherry Orchard. Speech act theory (SAT) initially proposed by Austin and further developed in works by Searly is based on an assumption that a speaker pronounces each utterance in order to achieve a specific communicative goal, whereby each goal is connected to a specific speech act, such as requests, refusals, compliments, criticisms, etc. [Salam El-Dakhs et al.: 494]. Systems for analyzing speech acts in conversational settings have been subsequently developed [e.g., Asher and Lascarides]. Speech act theory is widely employed in linguistics, particularly in its subdiscipline called Pragmatics that explores interactions between context and text/speech meaning). Since "literature consists of language", SAT has also had an impact on literature studies [Petrey: 3] becoming "a recognized category of current literary theory" [Gorman: 93].

Chekhov's dramas are an object of inquiry in this paper for multiple reasons. Chekhov is celebrated around the world as "a master playwright" [Dominiczak: 703], who keeps affecting contemporary literature and art [Kataev]. He is known for insightful reflections on human nature, which are attributed to his medical doctor experiences of a "listener" of real life dramas [Dominiczak: 703]. His realism bordering on modernism recreates "life as it is" in a "fictional universe" [Shcherbenok: 297-298]. His language has been described as being simple, close to conversational, with the use of vernacular [Wood:25]. His major plays (three of which are selected for the analysis in this article) remain in the foreground of literary studies [Whyman]. As outlined in earlier research, Chekhov's characters "perceive the world, themselves and each other inaccurately" [Shcherbenok: 299]. From the viewpoint of speech acts, perceiving oneself inaccurately can result with either too positive or too negative self-assessment. In this article, we focus on self-praise or positive self-assessment/self-representation. 
Self-praise (an act of praising or complimenting oneself, providing a positive self-assessment/self-representation) is described as a "self-elevating behavior in interaction" [Wu: 3153]. In this paper, we present self-praise speech act as a continuum ranging from a positive self-assessment or selfrepresentation (understood as synonyms) to a boasting spree, i.e., it is the magnitude (strength) of positive self-representation that counts.

Self-praise remains an understudied speech act, since it is often frowned upon in many cultures due to its reputation of being disruptive or immodest [Dayter, 2014; 2018]. Even in cultures where self-praise is an undesirable behavior in general, such as Chinese [Wu], a speaker can encounter a situation when he/she/ze needs to promote oneself or project a desirable image of oneself. For example, a positive self-representation can arise as a reaction to a verbal attack, an attempt to stand one's ground, etc. Some specific genres and situations of language use have been identified where some use of self-praise is tolerated, expected, or even required, e.g., job interviews, political speeches or computer-mediated communication [Dayter 2018; Matley]. Due to social constraints on self-praise, it often comes with some kind of mitigation or attenuation, such as a disclaimer, a shift of focus, self-denigration, reference to hard work [Dayter 2014: 91], reporting other people's words, disclaimer of an extreme situation, playing a sufferer, i.e., treating the matter as complainable [Wu: 3153]. Besides mitigation (making the force of the speech act milder), speech acts can also come with aggravation (making it stronger) [Benoit \& Benoit; De Pablos-Ortega]. However, so far, aggravation in self-praise has remained outside of the scope of research investigations.

While there is a body of literature on the expression of speech acts in Russian [e.g., Gabidullina; Diachkova], to the best of our knowledge, there are no full-fledged studies of self-praise in Russian contexts, probably due to the fact that Russian culture is overall not very supportive of selfpraise, which is associated with stupidity [Krysin]. Self-praise (похвальба) is, however, included in the list of Russian speech genres [e.g., Dementev: 41]. The aim of this paper is to fill in the above gap in research by exploring the use of self-praise/positive self-assessment in three Chekhov's plays The Seagull, Three Sisters and The Cherry Orchard. The research questions of the study are: (1) Do characters in these plays employ self-praise/positive selfassessment? (2) Which characters may use this speech act, and how does it contribute to the image of the character? (3) If there are instances of selfpraise, does it come with any attenuation (mitigation) or aggravation? 


\section{Materials and methods}

The study is based on a qualitative descriptive examination of the selfpraise/positive self-assessment speech acts. The three selected plays have very similar total word numbers between 13,000 and 16,000 words each (Ref. Table 1), therefore, they are well compatible for speech acts research. The texts of the plays (close to 30,000 words) were manually examined for instances of self-praise/positive self-representations, the strength of the speech act, presence/lack of attenuation and aggravation, and the type of attenuation and aggravation (by grammar-syntactical or discoursal means). The self-praise acts were tagged as belonging to the following categories by force: (1) a weak positive self-representation, (2) a medium strength positive self-representation, (3) a strong positive emphatic selfrepresentation, (4) a boast of one's abilities, position, etc., (5) an extended bragging spree. The tagging was done by the author according to the length of the act in words, the vocabulary (emphatic/non-emphatic) and the semantics of the act. Possible mitigation and aggravation types were identified based on earlier studies [Benoit \& Benoit; Dayton 2014, 2018; De Pablos-Ortega; Wu].

It should be noted as a limitation of the study that speech act and its strength identification are subjective, as they are based on the author's reading of the text. Perhaps, in future, more experimental techniques with other human readers assessing the strength of speech acts could help to add more objectivity to the results. Automated analysis was impossible, because it usually relies on queries for lexical markers [Dayton 2018], and up-to-date, to the best of our knowledge, there is no list of collocation markers for self-praise in Russian. The analysis method is Functional Communicative Grammar (FCG), since it accounts for semantic and communicative aspects of texts as well as text structure and functioning, and one of Chekhov's short story texts has already been analyzed using this approach [Kolyaseva: 642]. The analysis data were tabulated, and are presented in the Results section in an aggregated form as well as in text illustrations. 


\section{Results}

The answer to research question 1 (Do characters in the examined Chekhov's plays employ self-praise/positive self-assessment?) is a definitive 'yes', as summarized in Table 1. Unexpectedly, the highest number of instances of self-praise comes from 'Three Sisters' (where there are no super-achievers or vain artists amongst the characters), and the lowest - from 'The Seagull' which examines literary and theatrical lives and features two literary authors and two actresses among its characters.

The answers to research questions 2 and 3 are presented in the descriptions of the self-praise acts in the characters' lines in each of the three plays.

Table 1 - The total number of self-praise counts

for the three analyzed Chekhov's plays

Таблица 1 - Общее количество самовосхвалений

в трех проанализированных пьесах Чехова

\begin{tabular}{|c|c|c|}
\hline Play & N words & N self-praise acts \\
\hline The Seagull & 13763 & 11 \\
\hline The Cherry Orchard & 13157 & 17 \\
\hline Three Sisters & 16439 & 34 \\
\hline total & 29596 & 62 \\
\hline
\end{tabular}

\section{The Seagull}

The results of the distribution of self-praise and self-praise mitigation by character are summarized in Table 2. As the Table 2 shows, the major producer of self-praise in the drama is Irina Arkadina, an aging actress (6/11 instances of self-praise). Her self-praise has no specific context, reason or function, except for self-indulgence. Arkadina's self-praise is strong (evaluated as 3.8/5 on the average). In particular, she engages in one full notorious bragging spree that makes her sound grotesque (Example 1): 


\section{Example 1}

«Затем, я корректна, как англичанин. Я, милая, держу себя в струне, как говорится, и всегда одета и причесана comme il faut. Чтобы я позволила себе выйти из дому, хотя бы вот в сад, в блузе или непричесанной? Никогда. Оттого я и сохранилась, что никогда не была фефёлой, не распускала себя, как некоторые... (Подбоченясь, прохаживается по площадке.) Вот вам - как цыпочка. Хоть пятнадцатилетнюю девочку играть» [Chekhov: 172-174].

It should be noted that Arkadina's bragging monologue includes a codeswitch to French (comme il faut) as a part of the above brag, which may reflect her ambition of being seen as an educated lady of high society, but the French expression makes the whole boasting spree even more ridiculous, as the use of French was considered unpatriotic by Russian intelligentsia since mid-nineteenth century [Offord, et al., 2018].

There are two major objects of her self-praise. The first one is related to her looks: appearing youthful, holding it together, being well dressed and always styling her hair, not letting herself go. The second object of her selfpraise is related to her artistic work and talent: working, feeling, being in the middle of things, having an exciting occupation, being well received, having an ovation, receiving flowers and presents from fans. Her vain-glory could be a reflection of one of the things Chekhov hated about the theatre and actors [Goriacheva].

Arkadina's self-praise is mildly mitigated only in three (out of 6) instances, when she uses impersonal sentences to report fans' admiration of her acting: «Как меня в Харькове принимали, батюшки мои, до сих пор голова кружится» [Chekhov: 228]. In one self-praise act, she starts with a slightly mitigated grammatically impersonal self-praise in a relatively formal style Russian, where the grammatical subject is not Arkadina herself, but her exquisite outfit: «На мне был удивительный туалет...», but she immediately continues with a direct in-your-face boast in the first person singular that sounds colloquial, almost vernacular: «Что-что, а уж одеться я не дура» [Chekhov: 228].

One striking feature of Arkadina's self-praise is that her own perfections are juxtaposed (in 3 cases) against her critique or denigration of other people, e.g., «...я работаю, я чувствую, я постоянно в суете, а вы сидите всё на одном месте, не живете...» [Chekhov: 172]. Instances of self-praise 
combined with criticism or denigration of others have been subsequently observed in the lines of other characters and entered in Table 2.

As Arkadina's son Treplev says about her in the play, she craves other people's praise as self-validation: «Нужно хвалить только ее одну, нужно писать о ней, кричать, восторгаться ее необыкновенною игрой» [Chekhov: 150]. If the daily praise is not coming in satisfying amounts, she praises herself, or she shamelessly solicits praise from others, for example, by asking who looks more youthful - she (at the age of over 40 ) or a 22-year old Masha.

Two self-praise acts are found in the lines of Evgeny Dorn, a medical doctor. He provides a positive self-representation of himself as a good doctor and an honest man (Example 2), which comes contextually as a response to a verbal provocation by Polina who accuses him of being a lady's man.

\section{Example 2}

«В отношениях женщин ко мне было много хорошего. Во мне любили главным образом превосходного врача. Лет 10-15 назад, вы помните, во всей губернии я был единственным порядочным акушером. Затем всегда я был честным человеком» [Chekhov: 156].

The self-praise strength in Example 2 is classified as " 3 " (strong positive emphatic self-representation). It starts as mitigated (reporting other people's opinions, impersonal), and then progresses to an unmitigated positive selfrepresentation (in first person singular). Another positive self-representation (strength: 2) occurs in Dorn's advice to Treplev to carry on writing. The purpose of this positive self-representation is to emphasize the value of advice as coming from a life's 'expert': «Вы знаете, я прожил свою жизнь разнообразно и со вкусом, я доволен...» The self-praise is mitigated phrasally by 'you know' (вы знаете) [Chekhov: 170].

Treplev, a young author who is torn by self-doubt (as well as by unreciprocated love) produces just one utterance of a positive self-assessment (strength=3) which contextually comes as a response to his mother's scolding him for having no talent and being envious of an established writer (as well as her boyfriend) Trigorin (Example 3). There is a very slight phrasal attenuation "коли на то пошло" (if it comes to this). The positive selfevaluation is followed by a strong emotive critique (denigration) of others (Ref Example 3). 


\section{Example 3}

«Треплев (иронически). Настоящие таланты! Я талантливее вас всех, коли на то пошло! Вы, рутинеры, захватили первенство в искусстве и считаете законным и настоящим лишь то, что делаете вы сами, а остальное вы гнетете и душите! Не признаю я вас! Не признаю ни тебя, ни его!» [Chekhov: 202].

Nina Zarechnaya, a young promising actress, only utters one positive statement about herself. Notably, it only happens in the end of the play after she has developed confidence in herself as an actress: «Я уже настоящая актриса, я играю с наслаждением, с восторгом, пьянею на сцене и чувствую себя прекрасной» [Chekhov: 238]. This relatively strong positive self-representation (3) comes unjustified communicatively, as a need for selfexpression, and is not attenuated.

Masha, a secondary (supporting) character is hopelessly in love with Treplev, but as her feelings are not reciprocated, she decides to marry someone else, and she calls herself "brave" in recognition of the willpower required to take this decision: «А все же я храбрая. Вот взяла и решила: вырву эту любовь из своего сердца, с корнем вырву» [Chekhov: 192]. This positive self-representation is of medium strength (2) and comes without attenuation.

It appears to be worth noting that only five out of a total of thirteen characters in the play are provided by Chekhov with an opportunity to say something positive about themselves. Some major characters do not engage in self-praise even if they could be considered 'eligible' to some selfadmiration. It is somewhat surprising that Trigorin, who is portrayed as a relatively famous writer, has a low opinion of himself, and does not produce a single positive self-assessment utterance. Quite the opposite, he is full of self-loathing. 
Table 2 - A summary of self-praise/positive self-assessment speech acts in 'The Seagull' (by character)

Таблица 2 - Количество и типы речевых актов самовосхваления/положительной самооценки в «Чайке» (по персонажам)

\begin{tabular}{|l|l|r|l|l|l|}
\hline Characters & self-praise act & Strength & Mitigation & Mitigation type & $\begin{array}{l}\text { Aggravation } \\
\text { (other- } \\
\text { criticism })\end{array}$ \\
\hline Arkadina & A1 & 3 & no & N/A & yes \\
& A2 & 5 & no & N/A \\
& A3 & 3 & no & N/A \\
& A4 & 4 & yes & reporting & yes \\
& A5 & 4 & yes & reporting & no \\
& A6 & 4 & yes & impersonal & no \\
\hline Dorn & D1 & 3 & yes & reporting & no \\
D2 & 2 & yes & phrasal & no \\
\hline Treplev & T1 & 3 & yes & phrasal & yes \\
\hline Zarechnaya & N1 & 3 & no & N/A & no \\
\hline
\end{tabular}

Note: Characters whose lines have no self-praise speech acts are excluded from this and subsequent tables.

\section{The Cherry Orchard}

The second of the three plays by the number of self-praise/positive selfassessment acts is 'The Cherry Orchad' (Ref. Table 3 for the distribution of self-praise acts and their mitigation by characters). 
Table 3 - A summary of self-praise/positive self-assessment speech acts in The Cherry Orchard (by character)

Таблица 3 - Количество и типы речевых актов самовосхваления/ положительной самооценки в «Вишневом саду» (по персонажам)

\begin{tabular}{|c|c|c|c|c|c|}
\hline $\begin{array}{l}\text { Charac- } \\
\text { ters }\end{array}$ & $\begin{array}{c}\text { self-praise } \\
\text { act }\end{array}$ & Strength & Mitigation & Mitigation type & $\begin{array}{l}\text { other } \\
\text { criti- } \\
\text { cism }\end{array}$ \\
\hline \multirow[t]{5}{*}{ Lopakhin } & L1 & 2 & yes & $\begin{array}{l}\text { humble origins, phrasal, } \\
\text { self-derogation }\end{array}$ & no \\
\hline & $\mathrm{L} 2$ & 3 & yes & $\begin{array}{l}\text { humble origin, self- } \\
\text { derogation }\end{array}$ & no \\
\hline & L3 & 4 & yes & irony & no \\
\hline & $\mathrm{L} 4$ & 3 & yes & humble origins & no \\
\hline & L5 & 2 & yes & phrasal & yes \\
\hline \multirow[t]{5}{*}{ Trofimov } & $\mathrm{T} 1$ & 4 & no & N/A & yes \\
\hline & $\mathrm{T} 2$ & 3 & yes & 1st person plural «my» & no \\
\hline & $\mathrm{T} 3$ & 2 & no & N/A & no \\
\hline & $\mathrm{T} 4$ & 2 & no & $\mathrm{N} / \mathrm{A}$ & yes \\
\hline & T5 & 4 & no & N/A & yes \\
\hline \multirow[t]{3}{*}{ Dunyasha } & D1 & 3 & no & N/A & no \\
\hline & D2 & 2 & no & N/A & no \\
\hline & D3 & 1 & no & N/A & no \\
\hline Anya & A1 & 1 & no & N/A & no \\
\hline Gaev & G1 & 1 & yes & phrasal and impersoanl & no \\
\hline yasha & $\mathrm{J} 1$ & 3 & no & N/A & no \\
\hline Pishchik & $\mathrm{P} 1$ & 2 & yes & self-derogation & yes \\
\hline
\end{tabular}

It is interesting to note that two of the representatives of the 'new' generation and a new direction in Russian society (an entrepreneur Lopakhin and an eternal student Trofimov) are sharing equal numbers of self-praise in the text (5 each), and the strength of their self-praise is similar (average of 2.8 for Lopakhin and 3.0 for Trofimov). Lopakhin's praise is mitigated by references to his humble origins and self-derogation (Ref. Example 4). He also employs the phrasal type of mitigation. His self-praise is focused 
on his dandy outfit, the fact that he is rich and can pay for anything, his profit making skills, his triumph of becoming the owner of the cherry orchard estate, his hard work, and an understanding of his purpose in life. He symbolically contrasts his work with the critique of individuals who have no purpose in life (Example 5).

\section{Example 4}

«Отец мой, правда, мужик был, а я вот в белой жилетке, желтых башмаках. Со свиным рылом в калашный ряд. Только что вот богатый, денег много, а ежели подумать и разобраться, то мужик мужиком...» [Chekhov: 460].

\section{Example 5}

«Когда я работаю подолгу, без устали, тогда мысли полегче, и кажется, будто мне тоже известно, для чего я существую. А сколько, брат, в России людей, которые существуют неизвестно для чего» [Chekhov: 540].

His positive self-representations attenuated by self-criticisms and references to his slave origins are reflections of the complexity of this character, a destroyer of the past (cherry orchard), and a creator of the 'new order. Lopakhin has been seen as a "bridge from the past to the future, from Christianity to a superman," [Komarov: 107] and at the same time, he is a hamletian figure, with a strong connection to the past (his admiration of Ranevskaya and the cherry orchard).

By contrast, the rebellious eternal student Trofimov does not mitigate his self-praise. He also refers to himself a few times as "we" (which can be interpreted as a megalomaniac self-representation of himself as a spokesperson for the whole generation) (Example 6).

\section{Example 6}

«Она [Варя] своей узкой головой не может понять, что мы выше любви. Обойти то мелкое и призрачное, что мешает быть свободным и счастливым, - вот цель и смысл нашей жизни. Вперед! Мы идем неудержимо к яркой звезде, которая горит там вдали! Вперед! Не отставай, друзья!» [Chekhov: 508].

While Lopakhin uses other-criticisms only once in a mild form (Example 5), Trofimov's self-praise is combined with other-derogation in three out 
of five occurrences of self-praise, e.g., his condemnation of Varya in Example 6. Trofimov's brags pose him as a leader of the new rebellious generation marching towards an unidentified idealistic goal (likely a social revolution which could not be named due to censorship restrictions). His self-praise acts come in the form of a 'generation/social group' positive self-representations. $\mathrm{He}$ also attempts positive projections of himself as being above love, above the vulgar and mandane (пошлость), being a sufferer for the cause and a harbinger of a mysterious happy future. This active self-promotion of the 'new' generation is likely Chekhov's attempt to show the social change and the fall of the old order after the abolition of serfdom in Russia. On the other hand, Trofimov lives in a bath house (an abode of evil, according to Russian folklore) [Komarov:112], has a rather unattractive appearance and is called 'oblezlyj barin' (a shabby lord) by common people. Thus Chekhov makes Trofimov's pretence for being a 'hero of our time' somewhat pathetic, and uses self-praise acts (among other tools) to achieve this goal.

Dunyasha (a maid) makes three positive self-representations in which she describes herself as being sensitive, delicate, and incapable of simple life, almost like a noble lady (Example 7). Her self-praise comes unmitigated, and with no criticism of others.

\section{Example 7}

«Меня еще девочкой взяли к господам, я теперь отвыкла от простой жизни, и вот руки белые-белые, как у барышни. Нежная стала, такая деликатная, благородная, всего боюсь...» [Chekhov: 492].

Positive self-representations in the lines of other characters seem to highlight some nuances of their personas. Anya is portrayed in the beginning of the play as being almost a child, and to emphasize this perception, she utters only one little childish (unmitigated) brag about flying in a hot air balloon in Paris [Chekhov: 466]. Gaev (Ranevskaya's brother) only manages one weak mitigated positive self-representation in which he portrays himself as a sufferer for his convictions and being admired by peasants, all pointing out that he is not a bad person [Chekhov: 486]. The servant Yasha (a selfconceited unpleasant character) boasts about taking a courier train and going to Paris (unmitigated, aggravated by a criticism of Dunyasha) [Chekhov: 542]. A bankrupt landlord Pishchik who borrows money from everyone 
around can say at least one positive thing about himself (although mitigated by self-derogation) - that he is proud of his good health [Chekhov: 512].

\section{Three Sisters}

'Three Sisters' have the highest number of self-praise/positive selfassessment acts among the three plays (Ref. Table 4 for self-praise speech acts by character).

Table 4 - A summary of self-praise/positive self-assessment speech acts in Three Sisters (by character)

Таблица 4 - Количество и типы речевых актов самовосхваления / положительной самооценки в «Трех сестрах» (по персонажам)

\begin{tabular}{|c|c|c|c|c|c|}
\hline $\begin{array}{l}\text { Charac- } \\
\text { ters }\end{array}$ & $\begin{array}{c}\text { self- } \\
\text { praise } \\
\text { act }\end{array}$ & Strength & Mitigation & Mitigation type & $\begin{array}{c}\text { other } \\
\text { criticism }\end{array}$ \\
\hline \multirow[t]{8}{*}{ Kulygin } & K1 & 2 & no & N/A & no \\
\hline & $\mathrm{K} 2$ & 2 & no & N/A & no \\
\hline & K3 & 1 & no & N/A & no \\
\hline & $\mathrm{K} 4$ & 1 & no & $\mathrm{N} / \mathrm{A}$ & no \\
\hline & K5 & 1 & no & N/A & no \\
\hline & K6 & 3 & no & $\mathrm{N} / \mathrm{A}$ & no \\
\hline & K7 & 1 & no & N/A & no \\
\hline & K8 & 2 & no & $\mathrm{N} / \mathrm{A}$ & no \\
\hline \multirow[t]{5}{*}{ Prozorov } & P1 & 2 & yes & sufferer & no \\
\hline & $\mathrm{P} 2$ & 1 & yes & attribution to other & yes \\
\hline & P3 & 3 & yes & self-derogation & yes \\
\hline & $\mathrm{P} 4$ & 3 & yes & reference to the past & yes \\
\hline & P5 & 3 & yes & self-derogation & no \\
\hline \multirow[t]{3}{*}{ Natalia } & N1 & 3 & $\begin{array}{l}\text { mitigation/ } \\
\text { aggravation }\end{array}$ & & no \\
\hline & $\mathrm{N} 2$ & 2 & no & N/A & yes \\
\hline & N3 & 3 & no & $\mathrm{N} / \mathrm{A}$ & yes \\
\hline
\end{tabular}




\begin{tabular}{|cc|c|c|c|c|}
\hline & N4 & 1 & no & N/A & yes \\
& N5 & 3 & no & N/A \\
\hline Irina & N1 & 2 & no & N/A & no \\
& N2 & 2 & yes & reference to God & no \\
& N3 & 3 & yes & reference to God & no \\
\hline Soliony & N1 & 1 & yes & an example & no \\
& N2 & 3 & yes & self-criticism & yes \\
& N3 & 2 & yes & reporting & no \\
\hline Vershinin & N1 & 2 & no & N/A & no \\
\hline Tuzen- & N1 & 3 & yes & self-criticism & no \\
bach & N2 & 2 & yes & N/A & no \\
\hline Anfisa & N1 & 1 & yes & self-criticism & no \\
& N2 & 4 & yes & fate reference & no \\
\hline Olga & N1 & 1 & yes & self-criticism & no \\
& N2 & 3 & yes & reference to being forgotten & no \\
\hline Masha & N1 & 3 & yes & sufferer & yes \\
\hline Chebuty- & N1 & 2 & yes & self-irony & no \\
\hline
\end{tabular}

The most 'boastful' character is Kulygin (8/34 self-praise acts), a schoolteacher, married to Masha (the middle one of the three sisters). His boasts are weak (1.6 average strength) and are not mitigated (See Table 4). The high number of self-praise acts in Kulygin's lines is surprising at first glance, because there is not much for Kulygin to boast about. His means are moderate, and his wife is in love with another character (Vershinin). One possible interpretation of this paradox is that Kulygin's positive selfrepresentations may be addressed to himself more than to others. The purpose of his self-praise is to convince himself that his wife loves him by uttering repetitive chants: «Маша меня любит. Моя жена меня любит» [Chekhov: 358], and that he is content with his life: «Я доволен, я доволен, я доволен» [Chekhov: 414]. Some of Kulygin's positive self-representations come in response to potential social threats (such as seeing officers around the house): «Я педагог, и здесь в доме свой человек, Машин муж...» 
[Chekhov: 360] He also tried to improve Masha's perception of him in response to her verbal challenge (Example 8). His self-representations project a picture of a respectable occupation (a school teacher, later an inspector), a hard working, honest and simple person, who is content with his life. What is there not to like? And yet his wife does not like him at all. To explain to the audience why Kulygin is not a lovable character, Chekhov, first, gives him an unpleasant sounding last name which is derived from 'кулыга' (a salesman), and second, makes him recite Latin phrases and even insert grammar comments: «Рассчитывал провести вечер в приятном обществе и - o, fallacem hominum spem!.. Винительный падеж при восклицании...» [Chekhov: 398]. His wife Masha mocks his obsession with Latin by conjugating a verb "to love" in Latin. In other words, multiple Latin platitudes make Kulygin annoying, and he loses ground as compared to more interesting and handsome men in the play.

\section{Example 8}

«Мы с тобой не бедны. Я работаю, хожу в гимназию, потом уроки даю... Я честный человек. Простой... Omnia mea mecum porto, как говорится» [Chekhov: 414].

The runners-up in self-praise are two more not-so-likable characters of the play - Andrey Prozorov and his fiancé and subsequently wife Natalia, with five self-praise acts each. Andrey's self-praise acts appear slightly stronger in force than Kulygin's (2.4 on the average). Prozorov provides positive self-representations related to his reading and thinking at night, an intent to translate a book from English, his knowledge of French, German and English, his ambitions to become a famous scholar (Example 9) as well as being proud of his civil service [Chekhov: 422] (which goes contrary to his earlier statement in Example 9). Andrey's self-praise is rather indirect, mitigated as a 'sufferer' (in two cases), with an attribution to his father (one case), a self-derogation (in three cases), a reference to a 'dream', and a reference to the past and a generational self/other criticism (Example 10). It should be noted that three out of five self-praise speech acts uttered by Andrey contain aggravations, i.e., criticism/derogation of others. 


\section{Example 9}

«Мне быть членом здешней земской управы, мне, которому снится каждую ночь, что я профессор московского университета, знаменитый ученый, которым гордится русская земля!» [Chekhov: 370]

\section{Example 10}

«О, где оно, куда ушло мое прошлое, когда я был молод, весел, умен, когда я мечтал и мыслил изящно, когда настоящее и будущее мое озарялись надеждой? Отчего мы, едва начавши жить, становимся скучны, серы, неинтересны, ленивы, равнодушны, бесполезны, несчастны...» [Chekhov: 444].

The last instance of a positive self-representation by Prozorov comes from his 'vision' of a happy future (mitigated by a self-derogation) (Example 11). Notably, his vision contains no elements of a 'commissive', a speech act of a commitment to future actions, the happy future just 'happens' on its own.

\section{Example 11}

«Настоящее противно, но зато когда я думаю о будущем, то как хорошо! Становится так легко, так просторно; и вдали забрезжит свет, я вижу свободу, я вижу, как я и дети мои становимся свободны от праздности, от квасу, от гуся с капустой, от сна после обеда, от подлого тунеядства...» [Chekhov: 444].

Natalia, is perhaps the most unlikable of all Chekhov's characters in the three plays. Literary analysis works have referred to her as "a demonic witch", a "conqueror", and a "devil in the flesh" [Dimitrov: 62, 65], who "occupies" the Prozorovs' house [Baturina: 6]. Her positive self-representations are of medium strength (2.4 on the average). She uses one specific functional form of self-praise twice: she praises her children (without any sound reason) and at the same time praises herself, including references to herself as their mother, i.e., elevating herself as a woman who gave birth to and is bringing up such remarkable children (Example 12). In Example 12, "you think this is just the mother talking", looks like a mitigation of the praise of the child, but at the same time, she aggravates the self-praise by referring to herself as the mother of the wonder-child. There are no other mitigations of self-praise in Natalia's lines.

Two other brags are implicit: Natalia uses code-switches to her broken French twice in order to elevate herself and make her look educated 
(Example 13). In Example 13, there is no situational need to use French, except for a show-off, as any passers-by could potentially hear her yelling from the window and admire her linguistic prowess.

\section{Example 12}

«Вы думаете, во мне говорит только мать, но нет, нет, уверяю вас! Это необыкновенный ребенок» [Chekhov: 384].

\section{Example 13}

«Кто здесь разговаривает так громко? Это ты, Андрюша? Софочку разбудишь. Il ne faut pas faire du bruit, la Sophie est dormee deja. Vous etes un ours» [Chekhov: 444].

Finally, one (and only one) explicit brag by Natalia comes from her conversation with Olga, when Natalia claims full "domestic" powers and supreme knowledge on handling the servants, and ousters Olga from the household matters (Example 14). Example 14 is followed by an aggravating fit of rage (a demonstration of her new powers) in which she calls the old servant Anfisa names and demands that she is thrown out of the house.

\section{Example 14}

«Ты в гимназии, я - дома, у тебя ученье, у меня - хозяйство. И если я говорю что насчет прислуги, то знаю, что говорю; я знаю, что го-во-рю...» [Chekhov: 404].

Four instances of positive self-representations are found in the lines of Irina, the youngest of Prozorov sisters. Once, she compliments her own wonderous thoughts (Example 15). She also tells everyone about how excited she was taking her school-teacher examination and how she looks forward to her new life. After she decides to accept a proposal of Tuzenbach whom she does not love, she feels exhilarated and is eager to work (Example 16). Two of her positive self-representations are mitigated by references to God's will.

\section{Example 15}

«И какие чудные мысли волновали меня, какие мысли!» [Chekhov 336]. 


\section{Example 16}

«Всё в божьей воле, это правда. Николай Львович сделал мне предложение... Что ж? Подумала и решила. Он хороший человек, удивительно даже, такой хороший... И у меня вдруг точно крылья выросли на душе, я повеселела, стало мне легко и опять захотелось работать, работать...» [Chekhov: 432].

The next bragger-in-line is an officer Soliony with three positive selfrepresentations of moderate strength (2.0 average). Soliony is in love with Irina and kills her fiancé Tuzenbach in a duel a day before their planned wedding. Soliony mentions his physical strength, being more noble and honest than most people and compares himself to the famous Russian poet Lermontov (Example 17). This comparison is symbolic, since Lermontov was killed in a duel (unlike Soliony who kills another person in a duel), and it brings a dark note of apprehension to the play. All Soliony's instances of self-praise are mitigated: one offered as an example in an abstract discussion, another containing self-criticism, and the third (Example 17) includes a reference to other people's opinions ('as they say').

\section{Example 17}

«Но у меня характер Лермонтова. (Тихо.) Я даже немножко похож на Лермонтова... как говорят...» [Chekhov, 2010, p. 388].

Baron Tuzenbach, who is in love with Irina (the youngest of the three Prozorov sisters), produces two self-praise acts (one moderate, one strong). In one of them (unmitigated), he proclaims having a passion for life, fight and work [Chekhov: 369]. In the second one (also unmitigated), he tells Irina that despite his German name, he is Russian and Orthodox, and only retained German patience and stubbornness [Chekhov: 354]. The first of these is motivated by a positive self-disclosure to a woman he loves, and the second one is aimed at highlighting that he fits in her social circle.

Surprisingly, two positive self-representations in the play are produced by an old servant Anfisa. In one of them she describes herself as a hard worker in order to avoid an eviction from the house [Chekhov: 402]. In the second one, she praises her good luck of living with Olga in the school-owned apartment (Example 18). 


\section{Example 18}

«И-и, деточка, вот живу! Вот живу! В гимназии на казенной квартире, золотая, вместе с Олюшкой - определил господь на старости лет. Отродясь я, грешница, так не жила... Квартира большая, казенная, и мне цельная комнатка и кроватка. Все казенное. Проснусь ночью и - о господи, матерь божия, счастливей меня человека нету!» [Chekhov: 446].

Vershinin, one of the more likable characters (despite having a wife, two daughters and an affair with Masha), is assigned two prophetic monologues in the play, in which he justifies the purpose of life for the whole generation. This purpose is in living, suffering and working in order to secure a new happy life for future generations [Chekhov: 380]. This is a generational selfjustification and self-praise, which is hard to evaluate in terms of strength. In the second 'prophecy', he also includes a positive self-representation (ameliorated by self-criticism) of himself as a person who craves knowledge and comprehends well the most important truth (see Example 19).

\section{Example 19}

«...а между тем, чем больше живу, тем больше хочу знать. Мои волосы седеют, я почти старик уже, но знаю мало, ах, как мало! Но все же, мне кажется, самое главное и настоящее я знаю, крепко знаю... Мы должны только работать и работать, а счастье это удел наших далеких потомков» [Chekhov: 380].

The oldest of the three sisters, a school teacher, subsequently a headmistress Olga utters a weak self-praise only once, when she says that she feels younger than yesterday, and that she is only 28 years old (mitigated with self-criticism) [Chekhov: 336]. Just like Vershinin, in the last (fourth) act of the drama, she also utters a 'prophecy, a vision for the future, on behalf of all the three sisters and the whole generation (a generational positive selfrepresentation), in which she validates their lives.

\section{Example 20}

«Пройдет время, и мы уйдем навеки, нас забудут, забудут наши лица, голоса и сколько нас было, но страдания наши перейдут в радость для тех, кто будет жить после нас, счастье и мир настанут на земле, и помянут добрым словом и благословят тех, кто живет теперь. О, милые сестры, жизнь наша еще не кончена. Будем жить!» [Chekhov: 454] 
Masha, the middle sister married to Kalygin, cannot stand her husband and engages in an affair with married Vershinin. She delivers one act of selfpraise in which she portrays herself as a super-sensitive person disturbed by rudeness and lack of sophistication. The act is mitigated by portraying herself as a sufferer and aggravated by other-criticism (Example 21).

\section{Example 21}

«Про мужа я не говорю, к нему я привыкла, но между штатскими вообще так много людей грубых, не любезных, не воспитанных. Меня волнует, оскорбляет грубость, я страдаю, когда вижу, что человек недостаточно тонок, недостаточно мягок, любезен. Когда мне случается быть среди учителей, товарищей мужа, то я просто страдаю» [Chekhov: 372-374].

In addition, the military doctor Chebutykin boasts about not having done anything in his life, not having read a single book and not reading Dobroliubov (mitigated by self-irony) [Chekhov: 340].

\section{Discussion and conclusion}

The analysis of the speech act of self-praise/positive self-assessment in Chekhov's three plays demonstrates that he employs this device in a few functions. First, he uses self-praise acts to identify less likable characters (like Arkadina, Trofimov, Kulygin, Andrey Prozorov and Natalia), whose self-praise acts tend to be strong and unmitigated or even aggravated. In particular, Arkadina's brags in 'The Seagull' appear to be a sublimation of everything that Chekhov hated about the theatre and actors while at the same time being enchanted by them [Goryacheva: 34-43].

Second, to depict more likable characters, Chekhov scripts mild to moderate positive self-representations that are contextually justifiable: as a response to a verbal attack, a misrepresentation or threat, or as an attempt to fit in (e.g., Dorn in 'The Seagull' or Anfisa fearful of an eviction, or Tuzenbach identifying as Russian Orthodox in 'Three Sisters').

Third, one specific kind of self-praise act modification that Chekhov resorts to is a generational/group self-praise in the first person plural (with Trofimov posing as a new generation spokesperson in 'The Cherry Orchard', and Vershinin and Olga in 'Three Sisters'). Group positive self-representations 
typical for political leaders and social activists are used by Chekov as a literary device likely intentionally, as politics has been identified as one of the themes in his plays [Whyman].

Finally, there are also some specific applications of self-praise act in the plays. For example, Lopakhin's positive self-representations (often mitigated by self-criticism) reflect the advancement of a new social group of successful businessmen, an interest in this group may be rooted by a contrast with Chekhov's unhappy childhood spent in his father's failing grocery store that eventually got bankrupt [Bartlett; Chekhov,1960]. The final positive selfrepresentation by Anfisa gives an illusion of a happy ending for at least one character in the 'Three Sisters'. Partly, the self-praise in the plays is also a reflection of the characters' delusions, and seeing only what they want to see [Stepanov].

A specific type of self-praise found in Chekhov's plays are 'linguistic' brags, i.e., citations from Latin and French used by less likable characters like Kulygin, Natalia and Arkadina. While Chekhov himself had a "rigorous classical education in Taganrog gymnasium [Bartlett: 3] and knew Latin well, he also saw classical languages as a way of "hiding from real life," as also demonstrated in the character of another school teacher Belikov in Chekhov's short story "Man in a Case" [Bartlett: 5]. The use of French by Russian nobility lasted until the pre-revolutionary times, but from the mid-nineteenth century, Russian intelligentsia and some gentry were more affected by cultural nationalism that prioritized Russian [Offord et al.]. This may explain the paradox of French use by Natalia on the one hand (to signify that she is not patriotic and wants to pose as a high society lady), and a disparaging attitude to her not speaking it right (she is neither noble, nor well-educated), on the other hand. By contrast, the Prozorovs are the ones who are described as being fluent in a few foreign languages (coming from gentry origins), but not a single one of them code-switches in the 'Three Sisters' to any language other than Russian (placing them amongst the patriots).

Chekhov's expert use of self-praise in his plays questions the opinions expressed in earlier studies that his texts are not truly communicative [Ivleva: 123). From the viewpoint of Speech Act Theory, Chekhov's plays present an interesting material to explore speech act modifications, such as mitigation and aggravation. Mitigation reduces and aggravation strengthens the illocutionary force of an utterance [Benoit \& Benoit: 172], which is 
particularly important in case of the 'risky' speech acts, such as self-praise. Chekhov's plays provide illustrations to mitigated and aggravated self-praise, whereby more likable characters mitigate, and less likable - aggravate the speech act. The only type of aggravation observed in the plays is criticism or derogation of others. By combining self-praise with criticizing or putting down others, a character gets a 'short-cut' to the goal of the self-praise act, i.e., elevating oneself above others. The study also shows that specific grammarsyntactic types of self-praise attenuation in Chekhov's plays include the use of impersonal syntactic forms and reporting. It would be productive to compare these findings with the grammar-syntactic forms of self-praise attenuation in spoken Russian.

To conclude, discourse structures analysis has been identified as an emerging theme in literature studies [Peftiev: 3]. As our study seems to suggest, research investigations of speech acts in drama texts could be productive for literary theory, since they highlight the construction of the dialogue by the author, and assist with a better understanding of the characters as well as human values they are supposed to represent. Speech act studies of dramas may also give a much needed boost to the analysis of literary character [Weststeijn] as well as to philological analysis of the language of literature. 


\section{Список литературы \\ Источники}

Чехов Ал. П. Из детских лет А. П. Чехова // А. П. Чехов в воспоминаниях современников / под общ. ред. С. Н. Голубова, В. В. Григоренко, Н. К. Гудзия, С. А. Макашина, Ю. Г. Оксмана. М.: Худож. лит., 1960. С. 29-74.

Chekhov A. P. Plays. Russian classics in Russian and English. Medford, N.Y: Academic book solutions, 2010. $557 \mathrm{p}$.

\section{Исследования}

Батурина Е. А. «Три сестры»: метафизичность чеховского текста // Философия Чехова: Материалы Международной научной конференции / под общ. ред. А. С. Собенникова. Иркутск: Изд-во Иркут. гос. ун-та, 2008. С. 4-11.

Горячева М. О. Любил ли Чехов театр? // Философия Чехова: Материалы Международной научной конференции / под общ. ред. А. С. Собенникова. Иркутск: Изд-во Иркут. гос. ун-та, 2008. С. 34-43.

Дементьев В. В. Теория речевых жанров. М.: Знак, 2010, 600 с.

Дьячкова И. Г. Похвала и порицание как речевые жанры // Вестник Омского университета. 1998. Т. 3. С. 5-58.

Димитров Л. «Три сестры». Во имя отца // Философия Чехова: Материалы Международной научной конференции / под общ. ред. А. С. Собенникова. Иркутск: Изд-во Иркут. гос. ун-та, 2008. С. 60-68.

Габидуллина А. Р. Учебно-педагогический дискурс: категориальная структура и жанровое своеобразие: дис. ... д-ра филол. наук. Донецк, 2009. 206 с.

Ивлева Т. Г. Автор в драматургии А. П. Чехова. Тверь: Тверской гос. ун-т, 2001. $124 \mathrm{c}$.

Катаев В. Б. Чехов плюс... М.: Языки славянской культуры, 2004. 408 с.

Комаров С. А. Линия Лопахин - Трофимов в комедии А. П. Чехова «Вишневый сад»: философские обертоны // Философия Чехова: Материалы Международной научной конференции / под общ. ред. А. С. Собенникова. Иркутск: Иркут. гос. ун-т, 2008. C. 106-114.

Крысин Л. П. Современный русский язык: система, норма, узус. М.: Языки славянской культуры, 2010. 480 с.

Пефтиев В. И. А. П. Чехов и его современники в контексте общественных дискуссий рубежа XIX-XX вв. // Верхневолжский филологический вестник. 2018. Т. 4, № 15. C. 1-5.

Степанов А. Д. Проблемы коммуникации у Чехова. М.: Языки славянской культуры, 2005. 400 с.

Asher N., and Lascarides A. Logics of conversation, Cambridge: Cambridge University Press, 2003. $552 \mathrm{p}$.

Austin J. L. How to Do Things with Words. Oxford: Oxford University Press, 1962. $166 \mathrm{p}$.

Bartlett R. Chekhov: Scenes from a Life. London: Simon and Schuster, 2004. 401 p.

Benoit W. L. and Benoit P. J. Aggravated and Mitigated opening utterances // Argumentaion. 1990. No. 4. P. 171-183. 
Dayter D. Self-praise in microblogging // Journal of Pragmatics. 2014. No. 61. P. 91-102.

Dayter D. Self-praise online and offline // Internet Pragmatics. 2018. No. 1 (1). https:// doi.org/10.1075/ip.00009.day (дата обращения: 26.03.2021).

De Pablos-Ortega, C. "Would it be fair to say that you actively sought our material?": Mitigation and aggravation in police investigation interviews // Pragmatics and Society. 2019. No. 10 (1). P. 49-71. https://doi.org/10.1075/ps.00015.pab

Dominiczak M. H. Physician writers: Anton Chekhov // Clinical chemistry. 2014. No. 60 (4). P. 703-704.

Gorman D. The use and abuse of speech-act theory in criticism // Poetics Tiday. 1999. No. 20 (1). P. 93-119.

Kolyaseva A. F. Text from a functional communicative perspective: a linguistic analysis of Chekhov's humoresque "My her" // Text and Talk. 2017. No. 37 (5). P. 639-662.

Matley D. "This is NOT a \#humblebrag, this is just a \#brag": The pragmatics of selfpraise, hashtags and politeness in Instagram posts // Discourse, Context \& Media. 2018. No. 22. P. 30-38.

Offord D., Rjéoutski V., Argent G., Frijhoff W., Sanchez-Summerer K. The French Language in Russia: A Social, Political, Cultural, and Literary History. Amsterdam: Amsterdam University Press, 2018. 810 p.

Petrey S. Speech Acts and Literary Theory. London: Routledge, 2017. 186 p.

Salam El-Dakhs, D. A., Ambreen F., Zaheer M. and Gusarova Y. A pragmatic analysis of the speech act of criticizing in university teacher-student talk. The case of English as a lingua franca // Pragmatics. 2019. No. 29: 4. P. 493-520. https://doi.org/10.1075/ prag.18028.eld

Shcherbenok A. "Killing realism": Insight and meaning in Anton Chekhov // The Slavic and East European Journal. 2010. No. 54 (2). P. 297-316.

Searle J. R. Speech Acts. Cambridge: Cambridge University Press, 1969. 203 p.

Searle J. R. 'A taxonomy of illocutionary acts', in K. Gunderson (ed.), Language, Mind and Knowledge, Minneapolis, MN: University of Minnesota Press, 1975, pp. 344-369.

Weststeijn W. G. On the Analysis of Literary Character. Jan van der Eng's Narrative Model as a Contribution to the Theory of Character // Russian Literature. 2003. No. 54 (1-3). P. 415-429.

Whyman R. Anton Chekhov. New York: Routledge, 2011, 200 p.

Wood J. The unwinding stair. New Republic. 2003. No. 228 (9). https://newrepublic. com/article/66783/the-unwinding-stair (Accessed 28 March 2021).

$W u$ R. R. A conversation analysis of self-praising in everyday Mandarin interactions // Journal of Pragmatics. 2011. No. 43. P. 3152-3176. 


\section{References}

Baturina, E. G. “'Tri sestry': metafizichnost' chekhovskogo teksta” [“'Three Sisters': Metaphysical Properties of Chekhov's Text”]. Sobennikov, A. S., editor. Filosofiia Chekhova: Materialy Mezhdunarodnoi nauchnoi konferentsii [Chekhov's Philosophy: Materials of an International Research Conference]. Irkutsk, Irkutsk university press Publ., 2008, pp. 4-11. (In Russ.)

Goriacheva, M. O. "Liubil li Chekhov teatr?" ["Did Chekhov love theatre?"]. Sobennikov, A. S., editor. Filosofiia Chekhova: Materialy Mezhdunarodnoi nauchnoi konferentsii [Chekhov's Philosophy: Materials of an International Research Conference]. Irkutsk, Irkutsk university press Publ., 2008, pp. 34-43. (In Russ.)

Dement'ev, V. V. Teoriia rechevykh zhanrov [Theory of Speech Genres]. Moscow, Znak Publ., 2010, 600 p. (In Russ.)

Diachkova, I. G. "Pokhvala i poritsanie kak rechevye zhanry" ["Praise and Disapproval as Speech Genres”]. Vestnik Omskogo Universiteta, vol. 3, 1998, pp. 5-58. (In Russ.)

Dimitrov, L. “'Tri sestry': Vo imia ottsa” [“'Three Sisters': In the Name of the Father”]. Sobennikov, A. S., editor. Filosofiia Chekhova: Materialy mezhdunarodnoi nauchnoi konferentsii [Chekhov's Philosophy: Materials of an International Research Conference]. Irkutsk, Irkutsk university press Publ., 2008, pp. 60-68. (In Russ.)

Gabidullina, A. R. Uchebno-pedagogicheskii diskurs: kategorialnaia struktura $i$ zhanrovoe svoeobrazie [Educational Discourse: Categorical Structure and Genre Idiosyncrasies: PhD thesis]. Donetsk, 2009. 206 p. (In Russ.)

Ivleva, T. G. Avtor v dramaturgii A. P. Chekhova [The author in A. P. Chekhov's dramas]. Tver,' Tver' State University Publ., 2001. 124 p. (In Russ.)

Kataev, V. B. Chekhov plius... [Chekhov plus...]. Moscow, Iazyki slavianskoi kul'tury Publ., 2004. 408 p. (In Russ.)

Komarov, S. A. "Liniia Lopakhin - Trofimov v komedii A. P. Chekhova 'Vishnevyi sad': filosofskie obertony" ["The Line Lopakhin - Trofimov in the Comedy "The Cherry Orchard' by A. P. Chekhov: Philosophical Overtones"]. Sobennikov, A. S., editor. Filosofiia Chekhova: Materialy mezhdunarodnoi nauchnoi konferentsii [Chekhov's Philosophy: Materials of an International Research Conference]. Irkutsk, Irkutsk university press Publ., 2008, pp. 106-114. (In Russ.)

Krysin, L. P. Sovremennyi russkii iazyk: sistema, norma, uzus [The Contemporary Russian Language: System, Norm, and Use]. Moscow, Iazyki slavianskoi kul'tury Publ., 2010. 480 p. (In Russ.)

Peftiev, V. I. “A. P. Chekhov i ego sovremenniki v kontekste obshchestvennykh diskussii rubezha XIX-XX vv." ["A. P. Chekhov and His Contemporaries in the Context of Public Discussions at the Turn of the $20^{\text {th }}$ Century"]. Verkhnevolozhskii filologicheskii vestnik, vol. 4, no. 15, 2018, pp. 1-5. (In Russ.)

Stepanov, A. D. Problemy kommunikatsii u Chekhova [Chekhov's Communication Issues]. Moscow, Iazyki slavianskoi kul'tury Publ., 2005. 400 p. (In Russ.)

Asher, Nicholas and Lascarides, Alex. Logics of Conversation. Cambridge, Cambridge University Press, 2003. 552 p. (In English) 
Austin, John Langshaw. How to Do Things with Words. Oxford, Oxford University Press, 1962. 166 p. (In English)

Bartlett, Rosamund. Chekhov: Scenes from a Life. London, Simon and Schuster, 2004. 401 p. (In English)

Benoit, William. L. and Benoit, Pamela J. "Aggravated and Mitigated opening utterances." Argumentation, no. 4 (2), 1990, pp. 171-183. (In English)

Dayter, Daria. "Self-praise in microblogging." Journal of Pragmatics, no. 61, 2014, pp. 91-102. (In English)

Dayter, Daria. "Self-praise online and offline." Internet Pragmatics, no. 1 (1), 2018. https://doi.org/10.1075/ip.00009.day (Accessed 28 March 2021). (In English)

De Pablos-Ortega, C. "'Would it be fair to say that you actively sought our material?': Mitigation and aggravation in police investigation interviews." Pragmatics and Society, no. 10 (1), 2019, pp. 49-71. https://doi.org/10.1075/ps.00015.pab (In English)

Dominiczak, Marek H. "Physician writers: Anton Chekhov." Clinical Chemistry, no. 60 (4), 2014, pp. 703-704. (In English)

Gorman, David. "The use and abuse of speech-act theory in criticism." Poetics Today, no. 20 (1), 1999, pp. 93-119. (In English)

Kolyaseva, Alena F. "Text from a functional communicative perspective: a linguistic analysis of Chekhov's humoresque 'My her'” Text and Talk, no. 37 (5), 2017, pp. 639-662. (In English)

Matley, David “'This is NOT a \#humblebrag, this is just a \#brag': The pragmatics of self-praise, hashtags and politeness in Instagram posts.” Discourse, Context \& Media, no. 22, 2018, pp. 30-38. (In English)

Offord, Derek; Rjéoutski, Vladislav; Argent, Gesine. The French Language in Russia: A Social, Political, Cultural, and Literary History. Amsterdam, Amsterdam University Press, 2018. 810 p. (In English)

Petrey, Sandy. Speech Acts and Literary Theory. London, Routledge, 2017. 186 p. (In English)

Salam El-Dakhs, Dina; A., Ambreen, Fatima; Zaheer, Maria and Gusarova Yulia. "A pragmatic analysis of the speech act of criticizing in university teacher-student talk. The case of English as a lingua franca." Pragmatics, no. 29 (4), 2019, pp. 493-520. https://doi.org/10.1075/prag.18028.eld (In English)

Shcherbenok, Andrey. "Killing realism': Insight and meaning in Anton Chekhov." The Slavic and East European Journal, no. 54 (2), 2010, pp. 297-316. (In English)

Searle, John R. Speech Acts. Cambridge, Cambridge University Press, 1969. 203 p. (In English)

Searle, John R. "A taxonomy of illocutionary acts." Gunderson, K., editor. Language, Mind and Knowledge. Minneapolis, MN, University of Minnesota Press, 1975, pp. 344-369. (In English)

Weststeijn, Willem G. "On the Analysis of Literary Character. Jan van der Eng's Narrative Model as a Contribution to the Theory of Character." Russian Literature, no. 54 (1-3), 2003, pp. 415-429. (In English) 
Whyman, Rose. Anton Chekhov. New York, Routledge, 2011. 200 p. (In English)

Wood, James. "The unwinding stair." New Republic, no. 228 (9) 2003. https:// newrepublic.com/article/66783/the-unwinding-stair (Accessed 28 March 2021) (In English)

$\mathrm{Wu}$, Ruey-Jiuan Regina. "A conversation analysis of self-praising in everyday Mandarin interactions." Journal of Pragmatics, no. 43, 2011, pp. 3152-3176. (In English) 


\title{
О подГотовКе в ИМЛИ РАН «Сочинений» Николая Соловьева
}

\begin{abstract}
Аннотация: Статья представляет собой анонс будущего собрания сочинений Николая Ивановича Соловьева (1831-1874), литературного критика, публициста и теоретика искусства шестидесятых годов XIX в. Представлена краткая история вопроса, обозначены главные достижения предшественников в освоении наследия Н. И. Соловьева, дан краткий очерк его литературной деятельности, а также предпринята попытка изложить основные идеи Н. И. Соловьева. Готовящееся в Отделе русской классической литературы ИМЛИ РАН собрание сочинений Н. И. Соловьева (в трех томах) станет первым научным изданием его трудов. В него войдут все литературно-критические, историко-литературные, публицистические, полемические, философские статьи Соловьева, а также научно-популярные работы, представляющие исторический и общекультурный интерес. Кроме текстов, первоначально опубликованных в периодических изданиях, будут представлены и позднейшие редакции статей из авторского собрания «Искусство и жизнь» (1869), для которых предусмотрен специальный раздел. Издание будет снабжено научным комментарием и аннотированным указателем имен. Откроет первый том издания вступительная статья В. И. Щербакова с очерком жизни и литературной деятельности Н. И. Соловьева. В завершающей части статьи изложены основные принципы подготовки будущего издания.
\end{abstract}

Ключевъе слова: Н. И. Соловьев, литературная критика, публицистика, этика, эстетика, нигилизм.

Информация об авторе: Виктор Игоревич Щербаков, кандидат филологических наук, старший научный сотрудник, Институт мировой литературы им. А. М. Горького РАН, ул. Поварская, д. 25 а, 121069 г. Москва, Россия.

ORCID ID: https://orcid.org/0000-0003-4769-6634

E-mail: Visher111@yandex.ru

Дата поступления статьи в редакиию: 13.02 .2021

Дата одобрения статьи рецензентами: 28.03 .2021

Дата публикации статьи: 28.06.2021

Для иитирования: Щербаков В. И. О подготовке в ИМЛИ РАН «Сочинений» Николая Соловьева // Два века русской классики. 2021. Т. 3, № 2. С. 230-243. https:// doi.org/10.22455/2686-7494-2021-3-2-230-243 


\author{
Dva veka russkoi klassiki, \\ vol. 3, no. 2, 2021, pp. 230-243. ISSN 2686-7494 \\ Two centuries of the Russian classics, \\ vol. 3, no. 2, 2021, pp. 230-243. ISSN 2686-7494 \\ Scientific Report
}

(c) Viktor I. Shcherbakov

A. M. Gorky Institute of World Literature of the Russian Academy of Sciences

Moscow, Russia

\title{
On "Works" by Nikolai Solovyov Being Prepared at the IWL RAS
}

\begin{abstract}
This article is an announcement of the future collected works by Nikolai Ivanovich Solovyov (1831-1874), literary critic, publicist and art theorist of the 1860s. A brief history of the issue is presented, main achievements of the predecessors in the elaboration of Nikolai Solovyov's literary heritage are indicated, a brief outline of his literary activity is given, and an attempt is made to present Solovyov's main ideas. The collected works of Soloviev (in three volumes) being prepared at the Department of Russian Classical Literature of the IWL RAS will be the first scientific publication of his works. This edition will include all the literary-critical, historical-literary, journalistic, polemical, philosophical articles by Solovyov, as well as the most significant popular science works of historical and general cultural interest. In addition to the texts originally published in periodicals, later versions of articles from the author's collection Art and Life (1869) will also be presented, for which a special section is intended. The edition will be provided with a scientific commentary and an annotated name index. The first volume of the edition will begin with an introductory article, which will include an essay on the life and literary activities of Solovyov (by Viktor Shcherbakov). At the end of the article, the basic principles of preparation of the future edition are outlined.
\end{abstract}

Keywords: Nikolai Soloviev, literary criticism, journalism, ethics, aesthetics, nihilism.

Information about the author: Viktor I. Shcherbakov, $\mathrm{PhD}$ in Philology, Senior Researcher, A. M. Gorky Institute of World Literature of the Russian Academy of Sciences, Povarskaya 25 a, 121069 Moscow, Russia.

ORCID ID: https://orcid.org/0000-0003-4769-6634

E-mail: Visher111@yandex.ru

Received: February 13, 2021

Approved after reviewing: March 31, 2021

Published: June 28, 2021

For citation: Shcherbakov, V. I. “On 'Works' by Nikolai Solovyov Being Prepared at the IWL RAS." Dva veka russkoi klassiki, vol. 3, no. 2, 2021, pp. 230-243. (In Russ.) https://doi.org/10.22455/2686-7494-2021-3-2-230-243 
Николай Соловьев пока еще остается в тени более известных однофамильцев - Сергея Михайловича и Владимира Сергеевича Coловьевых. Тем не менее имя это хорошо знакомо литературоведам, занимающимся изучением литературы 1860-х гг., в первую очередь специалистам по творчеству Ф. М. Достоевского и Д. И. Писарева, ибо Соловьев начинал свой литературный путь в журнале первого «Эпоха», а его полемика с писаревским "реализмом» составляла заметную часть журнальных споров той эпохи.

В истории русской литературы был продолжительный период, когда имя Николая Соловьева было практически забыто. В «Энциклопедическом словаре» Брокгауза и Ефрона (1900) ему посвящена небольшая анонимная статья (надо полагать, С. А. Венгерова, составлявшего отдел истории литературы), в которой перечислены основные работы критика, а также сказано, что он выступал «"во имя эстетики" энергичным противником идей Писарева и Чернышевского» и что «статьи его успеха не имели» [Брокгауз 30. 2: 796]. В двух изданиях «Большой энциклопедии» С. Н. Южакова (1900-1909, 22 т.) и в «Энциклопедическом словаре» братьев Гранат (1891-1948, 58 т.) сведений о Н. И. Соловьеве нет.

Впрочем, историческая оценка заслуг Соловьева-критика в дореволюционной печати была неоднозначной, о чем свидетельствует известная работа Акима Волынского (Хайма Флексера) «Русские критики» (1896), в которой Николай Соловьев характеризуется как литератор с «симпатичной физиономией», «обладавший несомненным талантом», эрудированный оппонент Чернышевского, Добролюбова и Писарева, боровшийся «во имя эстетического принципа против узких стремлений “экономизма” и утилитаризма» [Волынский: 161-162]. Сочувственная по тону статья о Соловьеве помещена также в томе 19 «Русского биографического словаря» А. А. Половцова (1909), где неиз- 
вестный автор, скрывшийся под криптонимом «А. Ш-ъ» (по всей вероятности, А. А. Шилов ${ }^{1}$ ), попытался изложить основные идеи критика, который стремился «поставить искусство в тесную связь с жизнью» и «одинаково отвергал как чуждую жизни идеализацию, так и сухой реализм» [РБС 19: 81].

Самым неблагоприятным в посмертной судьбе Соловьева был советский период, когда его упоминали редко и почти всегда с ярлыком «реакционный публицист и критик»². Характерно, что нет никаких сведений о Соловьеве ни в 11-томной «Литературной энциклопедии» (1929-1939), ни в 9-томной «Краткой литературной энциклопедии» (1962-1978), ни в «Большой советской энциклопедии» (1969-1978)3, что явно свидетельствует о неполноте этих изданий.

Если не считать кратких упоминаний о Николае Соловьеве в томах «Литературного наследства» и в комментариях к сочинениям писателей 1860-х гг. (Чернышевского, Писарева, Ткачева и др.), то началом научного изучения его наследия можно считать работу сотрудницы ИМЛИ РАН В. С. Нечаевой «Журнал М. М. и Ф. М. Достоевских “Эпоха" 1864-1865" [Нечаева]. В ней довольно подробно рассмотрены статьи Николая Соловьева, напечатанные в «Эпохе», и полемика его с Писаревым, но дальнейшая литературная судьба Соловьева осталась за рамками монографии. Нечаева еще была вынуждена оправдывать свой интерес к забытому критику тем, что ему покровительствовал сам Достоевский. И конечно, одна эта работа не могла повлиять на репутацию Соловьева в глазах советских литературоведов с их привычкой осторожничать и ждать «сигналов сверху».

Академический консерватизм по отношению к литературным заслугам Соловьева характерно проявился в монографии (докторской диссертации) Г. Г. Елизаветиной «Н. А. Добролюбов и литературный

1 Шилов Алексей Алексеевич (1881-1942), археограф и библиограф; редактировал «Словарь русских писателей и ученых» С. А. Венгерова, печатался в журналах «Былое», «Голос минувшего», «Книга и революция», «Красный архив», «Звезда» и др.

2 См. например, аннотированный указатель в т. 3 «Дневника» А. В. Никитенко (М.: ГИХЛ, 1956) и примечание, сопровождающее публикацию письма Н. И. Соловьева к Г. П. Данилевскому от 8 августа 1869 г. в работе Н. Г. Розенблюма: «Гончаров в неизданных письмах, дневниках и воспоминаниях» (Русская литература. 1969. № 1. С. 167-168).

3 То же относится и к предшествующим изданиям БСЭ. 
процесс его времени» (1990), где имя Соловьева отсутствует, хотя он сам многократно упоминал Добролюбова и посвятил ему две статьи, в которых подробно разобрал принципы добролюбовской «реальной критики» - «Добролюбов как критик» и «Добролюбов как мыслитель» (в составе цикла «Вопрос об искусстве», 1865).

В советское время была переиздана только одна статья Соловьева: «Война или мир? Критика нового произведения гр. Л. Н. Толстого» (1868), помещенная в сборнике И. Н. Сухих «Роман Л. Н. Толстого “Война и мир" в русской критике» (1989). Кроме того, отрывок из его статьи «Вопрос об искусстве» был включен в сборник «Роман И. А. Гончарова “Обломов” в русской критике» (1991).

Отношение к Николаю Соловьеву в нашем литературоведении стало меняться только с появлением работы Б. Ф. Егорова «Борьба эстетических идей в России 1860-х годов» (1991), не так давно вышедшей вторым изданием (2009), где писателю посвящен отдельный очерк. Б. Ф. Егоров справедливо заметил, что статьи Соловьева «не полемичны, а позитивны» и что «нелепо» видеть в нем «защитника реакции» [Егоров 2009: 497, 499]. Монография Егорова создавалась уже в новых исторических реалиях - в ней ощутимо стремление освободиться от идеологических штампов советской эпохи; литературный процесс 1860-х гг. предстает в ней уже не привычным ранжиром «вершин» и «величин», а многоцветной картиной, в которой достойное место занимают Д. И. Писарев, В. А. Зайцев, М. А. Антонович, А. А. Григорьев, С. С. Дудышкин, Е. Н. Эдельсон, Н. И. Соловьев. Заслуги последнего Б. Ф. Егоров оценил высоко, характеризуя его как писателя, который до самой кончины боролся пером «за Россию, за семью, за поэзию и красоту жизни...» [Егоров 2009: 503].

Показательно, что в монографии Г. Г. Елизаветиной «Писарев-критик. Испытание эстетикой» (1999) [Елизаветина] Соловьев уже не только упоминается, но и цитируется неоднократно, и то же относится к ПСС Д. И. Писарева в двенадцати томах (2000-2013), включая том писем ${ }^{1}$, где Соловьеву уделено видное место в комментариях. О растущем интересе к наследию Соловьева свидетельствовала в тот период и статья А. В. Косенковой «Главный оппонент - Н. И. Соловьев» (2000) [Косенкова], в которой объективно изложены обстоятельства полемики между Соловьевым и Писаревым.

1 Подготовлен автором статьи, В. И. Щербаковым. 
Этические воззрения Соловьева рассматривались в работах О. В. Рябова «Русская философия женственности: XI-XX века» (1999) [Рябов] и Н. Н. Старыгиной «Русский роман в ситуации философско-религиозной полемики 1860-1870-х годов» (2003) [Старыгина]. Последняя рассматривает Соловьева в одном ряду со Страховым, относя обоих к числу «христианских мыслителей». И хотя этику Соловьева, на наш взгляд, едва ли с полной уверенностью можно трактовать в духе «христианской антропологии» [Старыгина: 50-51], сама перемена вектора в оценке наследия Соловьева показательна.

Следует прибавить, что статьи о Соловьеве есть в энциклопедическом словаре С. В. Белова «Ф. М. Достоевский и его окружение» (2001) и в авторитетной энциклопедии «Русские писатели» (2007) 1 .

Словом, время забвения и замалчивания для Соловьева уже в прошлом, и сегодня есть все основания говорить о тенденции возрастания научного интереса к литературному наследию этого критика.

Таким образом, имя Николая Соловьева сегодня уже нельзя назвать забытым, но о широком интересе к его сочинениям говорить еще рано, поскольку они остаются малодоступными и малоизученными. Трехтомник избранных статей под заглавием «Искусство и жизнь», изданный в 1869 г. (при жизни и активном участии автора), остается единственным собранием его сочинений. Во всяком случае для пишущего эти строки ясно, что в его лице мы имеем талантливого критика 1860-1870-х гг., не понятого современниками, которого еще предстоит серьезно изучать много лет, пока истинный масштаб его дарования не прояснится вполне. И главным шагом на этом пути должно стать научное издание его основных статей.

\section{2}

Николай Соловьев вступил на поприще журналистики в 1864 г., в возрасте 33-х лет, будучи к тому времени дипломированным санитарным врачом военного ведомства. Его литературным дебютом явилась статья «Теория безобразия», направленная против журналистов «Русского слова», оценивавших искусство с позиций вульгарного утилитаризма (метившая главным образом в Д. И. Писарева). Статья Соловьева была напечатана в «Эпохе» (август 1864 г.) с развернутым примечанием Ф. М. Достоевского на первой странице. Писатель-редактор отметил

${ }^{1}$ Автором последней является Б. Ф. Егоров. 
«твердый, искренний и благородный тон этой статьи», «искреннее желание добра», а вместе и «наивность» автора, взявшего на себя неблагодарный труд разбирать нигилистические эскапады Д. И. Писарева и В. А. Зайцева. «Но несмотря на эту странную наивность, или, лучше сказать, может быть, через эту-то именно наивность, - статья г-на Соловьева нам особенно симпатична. Слышен голос свежий, голос, далекий от литературных сплетен и от всей этой литературной каши» [Достоевский 20: 228-229].

Похвала Достоевского имела большое влияние на судьбу Соловьева: он переезжает в Петербург и становится постоянным сотрудником «Эпохи». В течение второй половины 1864 г. и в начале 1865 г. он напечатал в журнале Достоевского шесть статей («Теория безобразия», «Теория пользы и выгоды», «Бесплодная плодовитость», «Женщинам», «Дети», «Разлад (Критика критики)»), и ещё несколько находились в работе. Однако весной 1865 г. Достоевский был вынужден прекратить издание журнала из-за финансовых проблем.

Тем не менее первые статьи Соловьева были замечены, прежде всего его идейными противниками, журналистами «Русского слова» и «Современника», которым и была адресована полемическая часть его статей. Больше всех в объяснениях с Соловьевым усердствовал Писарев, который реагировал на его «критику критики» с беспримерной грубостью, доходившей до прямых оскорблений, - явный признак того, что полемические выпады Соловьева достигали цели.

Кроме того, Соловьев был замечен в консервативных кругах как журналист, имевший репутацию непримиримого противника нигилизма. После закрытия «Эпохи» он быстро нашел себе место в журнале «Отечественные записки», где также стал постоянным сотрудником и напечатал шесть больших статей, в том числе обширную статью «Вопрос об искусстве», вышедшую первоначально в пяти статьях (каждая имела свое название), а после смерти редактора С. С. Дудышкина (16 сентября 1866 г.) и ликвидации старых «Отечественных записок» (в конце 1867 г. права на их издание приобрел Н. А. Некрасов) перешел в только что основанный журнал «Всемирный труд» (изд. Э. А. Хан), где на протяжении 1867 г. и до весны 1868 г. его статьи печатались из номера в номер.

Во «Всемирном труде» Соловьев помещал философские и полемические статьи, в том числе такие значимые, как «Принципы жизни» и 
«Идеалы». Значительный вес имели здесь также его литературно-критические выступления и обзоры, посвященные наиболее заметным событиям текущей литературы, в том числе «Дыму» И. С. Тургенева, «Петербургским трущобам» В. В. Крестовского, роману «Некуда» Н. С. Лескова.

Здесь же, в пяти номерах журнала, была напечатана одна из самых больших статей Соловьева, «Русская песня» (посвященная в большей мере былинам), в которой он выходит на широкие обобщения - размышления о своеобразии русского характера, о народности литературы, о патриотизме и космополитизме, о «лишних, ненужных людях» в нашем отечестве.

В конце 1860-х гг. Соловьев получил предложение начинающего издателя С. П. Анненкова подготовить собрание своих сочинений (в трех частях) и отнесся к этой идее с присущей ему серьезностью. Он не только отобрал для этого издания лучшие, с его точки зрения, статьи, но и дал им вторую жизнь, основательно их переработав. Была значительно сокращена полемическая часть статей, поскольку журналы «Русское слово» и «Современник» были закрыты правительством в 1866 г., а «главный оппонент», Писарев, погиб в 1868 г. —полемика с ними уже не имела смысла. Однако Соловьев не только сокращал свои статьи, но и дополнял их, развивая дорогие ему идеи и усиливая свою аргументацию более обстоятельным анализом доктрин Д. С. Милля, О. Конта, Г. Т. Бокля, Г. Л. Гельмгольца, А. Шлейхера и других тогдашних авторитетов. Основной задачей Соловьева на этом этапе была не борьба с «разрушителями» эстетики, а разработка собственной этико-эстетической доктрины.

\section{3}

Краеугольной идеей эстетики Соловьева было его убеждение, что способность к восприятию прекрасного неотделима от нравственности человека и составляет с ней единый комплекс. Эта мысль высказывалась им неоднократно, начиная с первой статьи, «Теория безобразия»: «...нравственное чувство есть не что иное, как чувство эстетическое, примененное только к действительной жизни» [Соловьев 1: 5], «это есть след ощущения красоты в природе и стремления осуществить эту красоту в жизни» [Соловьев 1: 141].

В этом убеждении Соловьева, надо полагать, сказалось влияние античного синкретизма, а именно калокагатии («прекрасно-доброго») 
древних греков, и в такой же мере можно предположить влияние христианской эстетики, неотделимой от христианской этики.

В отличие от прогрессистов из нигилистического лагеря, считавших искусство - в основной своей массе - тормозом на пути развития цивилизации (в их понимании состоявшей лишь в прогрессе науки, техники и общественно-политических институтов), Николай Соловьев считал искусство важнейшим цивилизующим средством, облагораживающим «зверообразные» инстинкты человека, гармонизирующим его двоякую природу.

В своих статьях, некоторые из которых представляют собой обширные трактаты, он стремился к построению синтетической доктрины, в которой находилось место и философии, и естествознанию, и религии. Это всеобъемлющая концепция, которая рассматривает изучение природы и человека как единый комплекс. Круг интересов Соловьева вообще был очень широк: этика, эстетика, художественная литератуpa, фольклор, лингвистика, естествознание. И закономерно, что ему были близки универсальные умы - И. В. Гете, Александр Гумбольдт, А. С. Пушкин.

Как теоретик искусства, он отстаивал идею неразрывности искусства и жизни, стремился поставить искусство в ряд основных потребностей человека, защищал его от нападок утилитаристов и нигилистов, много размышлял о сущности прекрасного, дополняя гипотезы философов-идеалистов открытиями ученых-естествоиспытателей.

Как литературный критик, Соловьев откликался на многие произведения современной ему литературы: он писал об «Обломове» и «Обрыве» Гончарова, о «Накануне», «Отцах и детях» и «Дыме» Тургенева, о романе «Что делать?» Чернышевского, о «Войне и мире» Толстого, о «Грозе» и других драмах Островского, о произведениях Лескова, Данилевского, Крестовского, а кроме того, упоминал в своих статьях многие другие романы, повести и пьесы. Пушкин, Гоголь, Гомер, Шекспир, Сервантес, Байрон, Гете были его любимыми классиками, их он упоминал и цитировал постоянно. Он подробно разбирал критическую деятельность Белинского, Добролюбова и Писарева, находя достоинства у всех, в том числе и чуждого ему по идеям Писарева.

Как публицист, Соловьев активно участвовал в обсуждении актуального тогда «женского вопроса», много высказывался по вопросам воспитания и образования, выступал в защиту традиционной семьи, 
материнства и детства. В своих общественных устремлениях Соловьев был писатель-моралист, желавший улучшить нравственный климат общества. Основным же средством исправления нравов он считал облагораживающее действие искусства.

Соловьев, без сомнения, сознавал свою миссию в литературе, потому и совершенствовал тексты своих статей. Его миссия заключалась в последовательной защите эстетических и нравственных ценностей от нападок «реальной критики», в отрицании «отрицателей» и «критике критики», в борьбе с рациональной этикой («разумным эгоизмом») и утилитарной эстетикой, в разоблачении философской нищеты нигилизма. И хотя он много сил отдавал полемике со своими идейными противниками, он никогда не опускался до грубостей. При этом он был одним из наиболее эрудированных критиков своего времени, умевшим не только выразить свое мнение, но и обосновать его.

\section{4}

Как и большинство литераторов той эпохи, Соловьев прожил трудную и короткую жизнь. Он умер на 43-м году от рождения, в первые часы 1874 г., от кровоизлияния в мозг, не оставив после себя никакого состояния, и был похоронен на деньги знакомых в московском Новодевичьем монастыре, где его могила существует и поныне (в хорошем состоянии). На гранитном постаменте написано: «Писатель-врач Нuколай Иванович Соловьев. Родился 1831 года августа 17-го дня. Умер 1 января 1874 года». Венчает постамент раскрытая книга. На одной странице начертано: «Искусство и жизнь», на другой - «Санитарные вопросы». У основания подпись: «Сооружен почитателями его трудов».

Смерть Николая Соловьева была замечена в литературном мире и за его пределами. Среди тех, кто откликнулся на его кончину, были такие крупные личности, как Ф. М. Достоевский, Н. П. Гиляров-Платонов, К. П. Победоносцев (последний был в числе жертвователей). Гиляров-Платонов, собиравший денежные средства, произнес на могиле Соловьева речь, в которой сказал: «В литературе для него не было лагерей; он вхож был в кружки, которые сами по себе были разделены, и лишь одно его возмущало и отталкивало - когда он видел отрицание нравственных начал, которых он был служителем» [Разумевающие верой: 163]. 
Жизнь Николая Соловьева, журналиста и врача, - это пример высокого и, в сущности, бескорыстного служения искусству в то непростое время, когда грубый утилитаризм в вопросах эстетики и морали считался признаком «передовой мысли», «чистое искусство» - презренным занятием людей, равнодушных к «голодным и раздетым» (Писарев), а слово «эстетик» употреблялось как синоним слова «бездельник». Те немногие, кто решался выступать тогда в защиту красоты и нравственности, сразу становились «ретроградами», а то и вовсе награждались оскорбительными прозвищами, как это и было с Соловьевым («приезжий из губернии», «лейтенант Жевакин» и т. п.), хотя, как санитарный врач, он более, чем кто-либо другой из тогдашних журналистов, заслуживал название «полезного деятеля».

$Ф$. М. Достоевский откликнулся на смерть Соловьева некрологом в «Гражданине», он вспомнил о том, что первая статья покойного критика была напечатана в его журнале «Эпоха» (исправив тем самым распространившиеся неверные сведения, что Соловьев якобы начинал в «Отечественных записках»), и охарактеризовал эту первую статью («Теория безобразия») как «весьма талантливо написанную» [Достоевский 21: 290]. Там же, в некрологе, им были сказаны пророческие слова: «...впоследствии, когда будут припоминать и пересчитывать всех замечательных литературных деятелей нашей эпохи, сгоряча не замеченных или криво понятых поколением, то наверно помянут добрым словом и более верною оценкой и чисто литературную деятельность покойного Соловьева» [Достоевский 21: 289]. Настало время это сделать.

\section{5}

Собрание «Сочинений» Соловьева (в трех томах) задумано как первое научное издание литературного наследия писателя. В него войдут все литературно-критические, публицистические, полемические, философские и научно-популярные работы, а также избранные статьи по санитарному делу, представляющие широкий исторический интерес, - «Москва и Петербург в санитарном отношении» (1871), «О народном здравии» (1871), «Скорбные листы Крымской кампании» (1872).

Научное издание «Сочинений» Соловьева готовится с ориентацией на современные научные издания писателей-классиков - в первую очередь на Полное собрание сочинений Д. И. Писарева в 12 т., подго- 
товленное в стенах ИМЛИ РАН (2000-2013) [Писарев]. Учитывается также опыт советских научных изданий критиков и публицистов XIX в. (В. Г. Белинского, А. И. Герцена, Н. Г. Чернышевского, Н. А. Добролюбова).

Большое место в готовящемся издании займет научный аппарат. Прежде всего, в нем будет значительный по объему раздел «Другие редакции», куда войдут тексты прижизненного собрания сочинений, существенно отличающиеся от первых, журнальных публикаций статей.

Все произведения будут расположены в строгом хронологическом порядке. За основной текст принимается текст первой публикации как наиболее адекватный «новостной» специфике критики и публицистики.

Тексты статей Соловьева будут приведены к современным нормам орфографии и пунктуации, но с сохранением тех лексических и грамматических особенностей, которые отражают нормы произношения своего времени или своеобразие индивидуального стиля (напр., «эманципация», «нежностию», «затрогивать», «волкан», «щедушный», «скрыпка», «маскерад» и т. п.) Имена собственные будут даны в оригинальной орфографии, например: «Гогарт» (Хогарт), «Люис» (Льюис), «Макс Миллер» (Макс Мюллер), «Форстер» (Фёрстер) и т. д.

Модернизация знаков препинания будет проводиться осторожно. Исправление оригинальной пунктуации необходимо в первую очередь там, где отсутствие знаков препинания затрудняет понимание текста. Дополнительные абзацы не вводятся.

Издание будет снабжено вступительной статьей с очерком жизни и летописью основных событий литературной биографии Соловьева (автор - В. И. Щербаков); тексты будут сопровождены обстоятельным научным комментарием (справочно-библиографическим, историко-литературным, реальным). При написании комментариев во главу угла ставятся лаконизм, ясность и достоверность приводимых данных.

В завершающем томе предполагается поместить аннотированный указатель имен, который позволит «разгрузить» реальный комментарий, поскольку многие имена и события упоминаются в текстах неоднократно.

Анонсируемый труд будет востребован как источник по истории русской критики и публицистики XIX в. Он позволит шире взглянуть на литературный процесс 1860-х гг., может быть использован при под- 
готовке собраний сочинений русских классиков, в монографических исследованиях и в практике университетского преподавания.

\section{Список литературы \\ Источники}

Белов С. В. Ф. М. Достоевский и его окружение: в 2 т. СПб.: Алетейя, 2001. Т. 2: Л - Я. $540 \mathrm{c.}$

Брокгауз Ф. А., Ефрон И. А. Энциклопедический словарь: в 41 т. СПб.: Тип. акц. об-ва «Издательское дело», Брокгауз-Ефрон, 1890-1907.

Роман Л. Н. Толстого «Война и мир» в русской критике / сост. И. Н. Сухих. Л.: Изд-во ЛГУ, 1989. 408 с.

Достоевский Ф. М. Полн. собр. соч.: в 30 т. Л.: Наука, 1972-1990

Егоров Б. Ф. Н. И. Соловьев // Русские писатели. М.: БРЭ, 2007. Т. 5. С. 748-750.

Писарев Д. И. Полн. собр. соч.: в 12 т. М.: Наука, 2000-2013.

Разумевающие верой: Переписка Н. П. Гилярова-Платонова и К. П. Победоносцева (1860-1887). Нечто о Русской церкви в обер-прокурорство К. П. Победоносцева / вступ. ст., сост., подгот. текстов и коммент. А. П. Дмитриева. СПб.: ООО Изд-во Росток, 2011.510 с.

Русский биографический словарь: в 25 т. СПб.: Имп. Рус. ист. о-во, 1896-1918.

Роман И. А. Гончарова “Обломов" в русской критике / сост. М. В. Отрадин. Л.: ЛГУ, $1991.305 \mathrm{c}$.

Соловвев Н. И. Искусство и жизнь: в 3 ч. М: Изд-е С. П. Анненкова, 1869.

\section{Исследования}

Волынский А. Л. Русские критики. СПб.: Тип. М. Меркушева, 1896. 827 с.

Егоров Б. Ф. Избранное. Эстетические идеи в России XIX века. М.: Летний сад, 2009. 663 c.

Елизаветина Г. Г. Писарев-критик. Испытание эстетикой. М.: ИМЛИ РАН, Наследие, 1999. $180 \mathrm{c}$.

Косенкова А. В. Главный оппонент - Н. И. Соловьев // Мир Д. И. Писарева. М.: ИМЛИ РАН, Наследие 2000. Вып. 2: Исследования и материалы. С. 139-161.

Нечаева В. С. Журнал М. М. и Ф. М. Достоевских «Эпоха» 1864-1865. М.: Наука, 1975. $303 \mathrm{c}$.

Рябов О. В. Русская философия женственности: XI-XX века. Иваново: ИЦ Юнона, 1999. 357 с.

Старыгина Н. Н. Русский роман в ситуации философско-религиозной полемики 1860-1870-х годов. М.: Языки славянской культуры, 2003. 352 с.

Щербаков В. И. Д. И. Писарев и литература эпохи нигилизма. М.: ИМЛИ РАН, 2016. $415 \mathrm{c}$. 


\section{References}

Volynskii, A. L. Russkie kritiki [Russian Critics]. St. Petersburg, Tipografiia M. Merkusheva Publ., 1896. 827 p. (In Russ.)

Egorov, B. F. Izbrannoe. Esteticheskie idei v Rossii XIX veka [Selected Works. Aesthetic Ideas in $19^{\text {th }}$ Century Russia]. Moscow, Letnii sad Publ., 2009. 663 p. (In Russ.)

Elizavetina, G. G. Pisarev-kritik. Ispytanie estetikoi [Pisarev as a Critic. The Test by Aesthetics]. Moscow, IWL RAS Publ., Nasledie Publ., 1999. 180 p. (In Russ.)

Kosenkova, A. V. "Glavnyi opponent - N. I. Solov'ev" ["The Main Opponent Nikolai Solovyov"]. Mir D. I. Pisareva [The World of D. I. Pisarev], issue 2: Research and Materials. Moscow, IWL RAS Publ., Nasledie Publ., 2000, pp. 139-161. (In Russ.)

Nechaeva, V. S. Zhurnal M. M. i F. M. Dostoevskikh "Epokha” 1864-1865 [Journal of Mikhail and Fyodor Dostoevskys "Epoch" 1864-1865]. Moscow, Nauka Publ., 1975. 303 p. (In Russ.)

Riabov, O. V. Russkaia filosofiia zhenstvennosti: XI-XX veka [Russian Philosophy of Femininity: $11^{\text {th }}-20^{\text {th }}$ Centuries]. Ivanovo, ITs Iunona Publ., 1999. 357 p. (In Russ.)

Starygina, N. N. Russkii roman v situatsii filosofsko-religioznoi polemiki 1860-1870-kh godov [Russian Novel in the Situation of Philosophical and Religious Polemics of the 1860s and 1870s]. Moscow, Iazyki slavianskoi kul'tury Publ., 2003. 352 p. (In Russ.)

Shcherbakov, V. I. D. I. Pisarev i literatura epokhi nigilizma [Pisarev and Literature of the Nihilist Era]. Moscow, IWL RAS Publ., 2016. 415 p. (In Russ.) 


\section{СЕТЕВОЕ ИЗДАНИЕ}

Научный журнал

Два века русской классики / Two centuries of the Russian classics

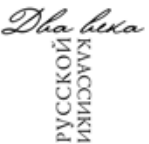

$$
2021-\text { T. } 3 \text { - № } 2
$$

Учредитель и издатель

Институт мировой литературы им. А. М. Горького

Российской академии наук

\section{Главный редактор}

Щербакова Марина Ивановна

доктор филологических наук, профессор,

заведующая отделом русской классической литературы ИМЛИ РАН

\section{Дизайн обложки и макет журнала Компьютерная верстка}

Д. К. Бернштейн А. З. Бернштейн

\section{Корректор}

В. Г. Андреева

Журнал зарегистрирован

Федеральной службой по надзору в сфере связи, информационных технологий и массовых коммуникаций (Роскомнадзор) Свидетельство о регистрации: ПИ № Эл 77-76366 от 02.08.2019 г.

Адрес учредителя, редакции и издателя:

121069, Москва, ул. Поварская, 25a

Тел.: (495)690-50-30

E-mail: journal_ork@mail.ru

Сайт журнала: www.rusklassika.ru

Дата размещения сетевого издания в сети Интернет на официальном сайте http://rusklassika.ru 28.06.2021 г.

При перепечатке ссылка обязательна 

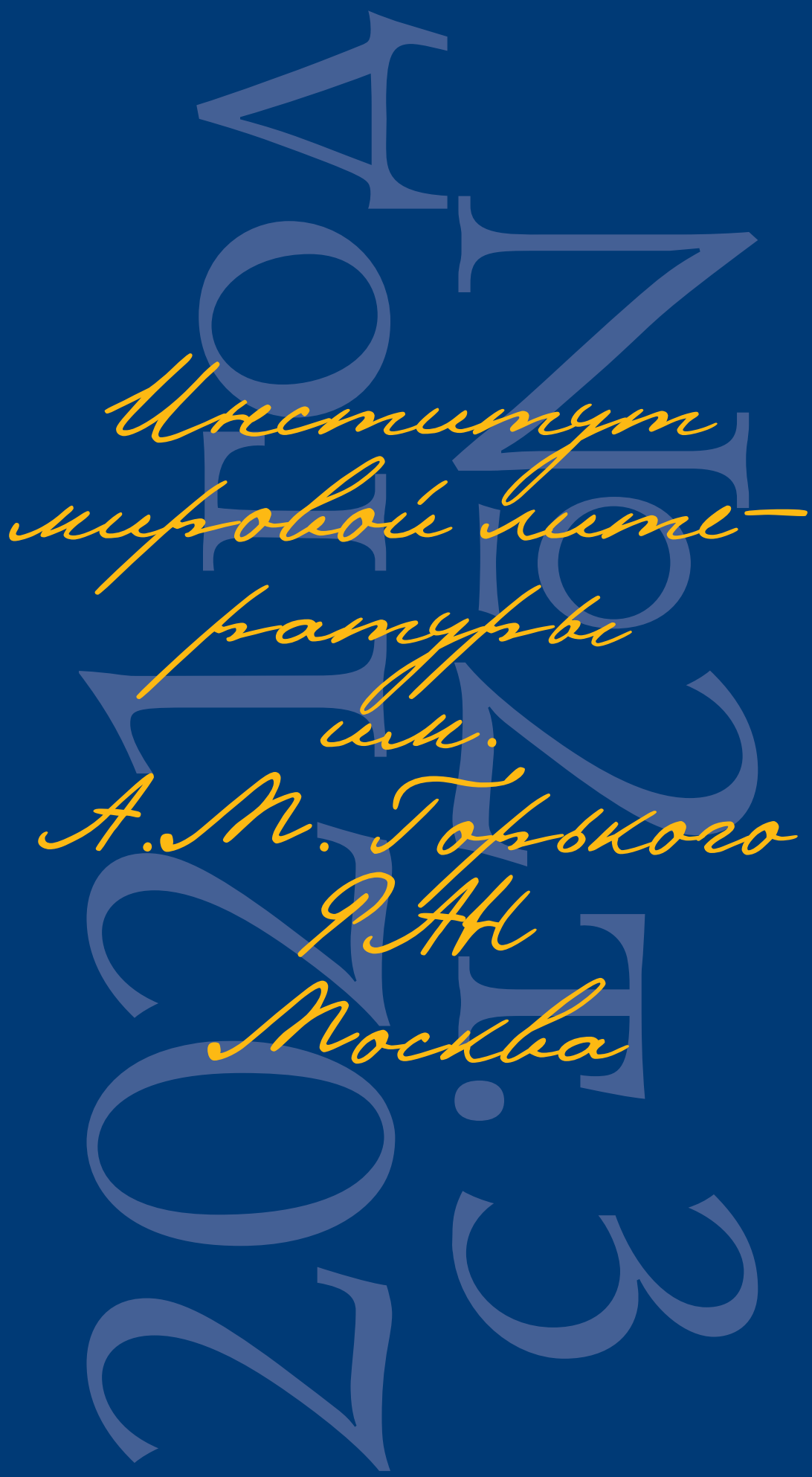